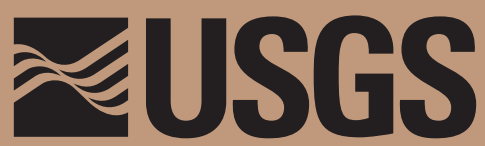

science for a changing world

\title{
Eruptive History and Chemical Evolution of the Precaldera and Postcaldera Basalt-Dacite Sequences, Long Valley, California: Implications for Magma Sources, Current Seismic Unrest, and Future Volcanism
}

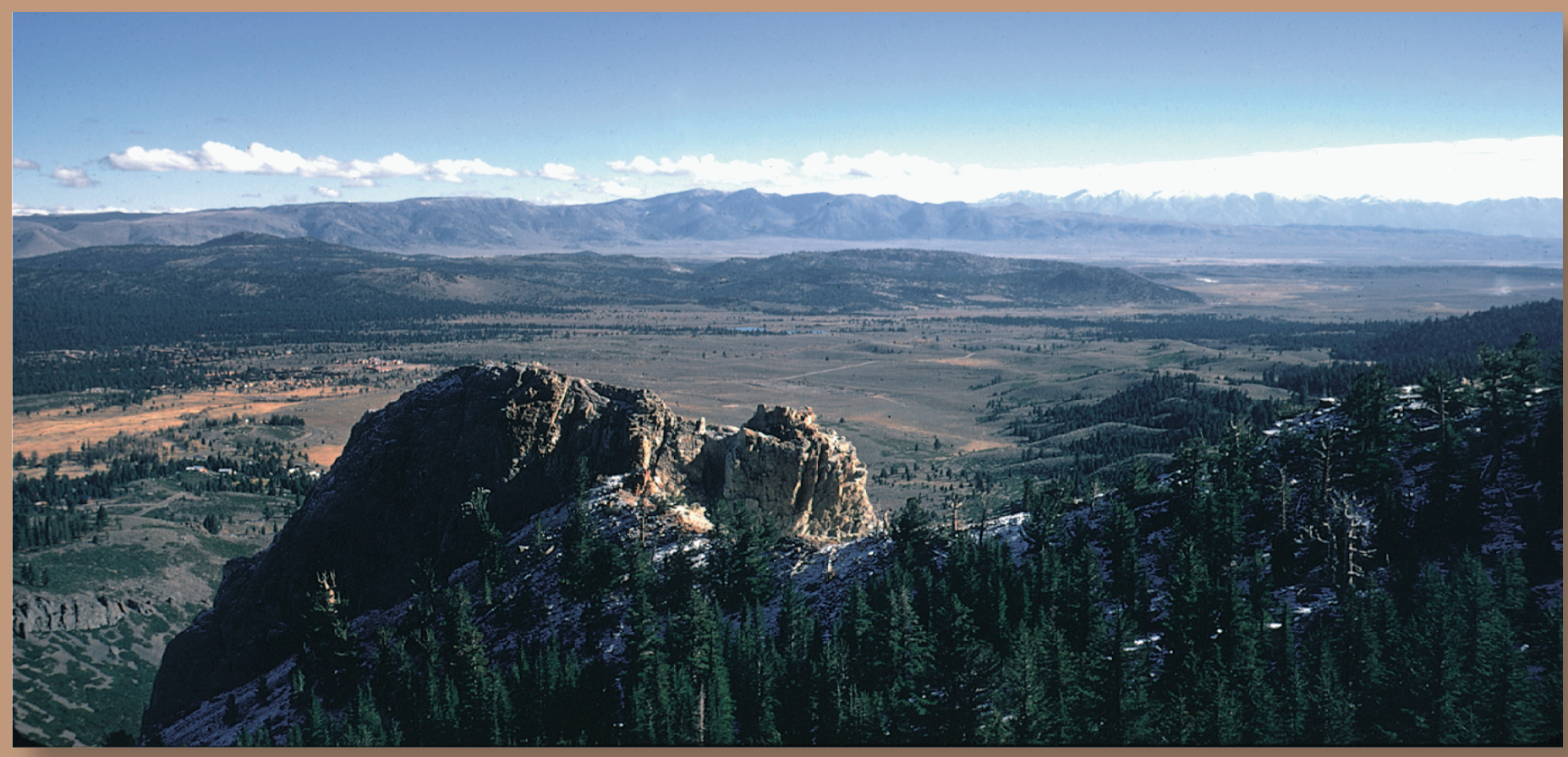

Professional Paper 1692

U.S. Department of the Interior

U.S. Geological Survey 
This page intentionally left blank 


\section{Eruptive History and Chemical Evolution of the Precaldera and Postcaldera Basalt-Dacite Sequences, Long Valley, California: Implications for Magma Sources, Current Seismic Unrest, and Future Volcanism}

By Roy A. Bailey

Professional Paper 1692 


\title{
U.S. Department of the Interior \\ Gale A. Norton, Secretary
}

\section{U.S. Geological Survey Charles G. Groat, Director}

\author{
U.S. Geological Survey, Reston, Virginia: 2004 \\ For sale by U.S. Geological Survey Information Services \\ Box 25286, Denver Federal Center \\ Denver, CO 80225 \\ This report and any updates to it are available online at: \\ http://pubs.usgs.gov//pp/p1692/ \\ Additional USGS publications can be found at: \\ http://geology.usgs.gov/products.html \\ For more information about the USGS and its products: \\ Telephone: 1-888-ASK-USGS (1-888-275-8747) \\ World Wide Web: http://www.usgs.gov/
}

Any use of trade, product, or firm names in this publication is for descriptive purposes only and does not imply endorsement of the U.S. Government.

Although this report is in the public domain, it contains copyrighted materials that are noted in the text. Permission to reproduce those items must be secured from the individual copyright owners.

Cataloging-in-publication data are on file with the Library of Congress (URL http://www.loc.gov/).

Produced in the Western Region, Menlo Park, California

Manuscript approved for publication, March 1, 2004

Text edited by George A. Havach

Layout and design by Sara Boore

Front Cover Long Valley Caldera from above Mammoth Rock on the southwest rim to Glass Mountain on the northeast rim $(30 \mathrm{~km})$. The resurgent dome is the forested ridge in the middle distance. The seismically and geothermally active south moat is the lowland in foreground. The White Mountains are snowcapped on the right horizon. View northeastward. 


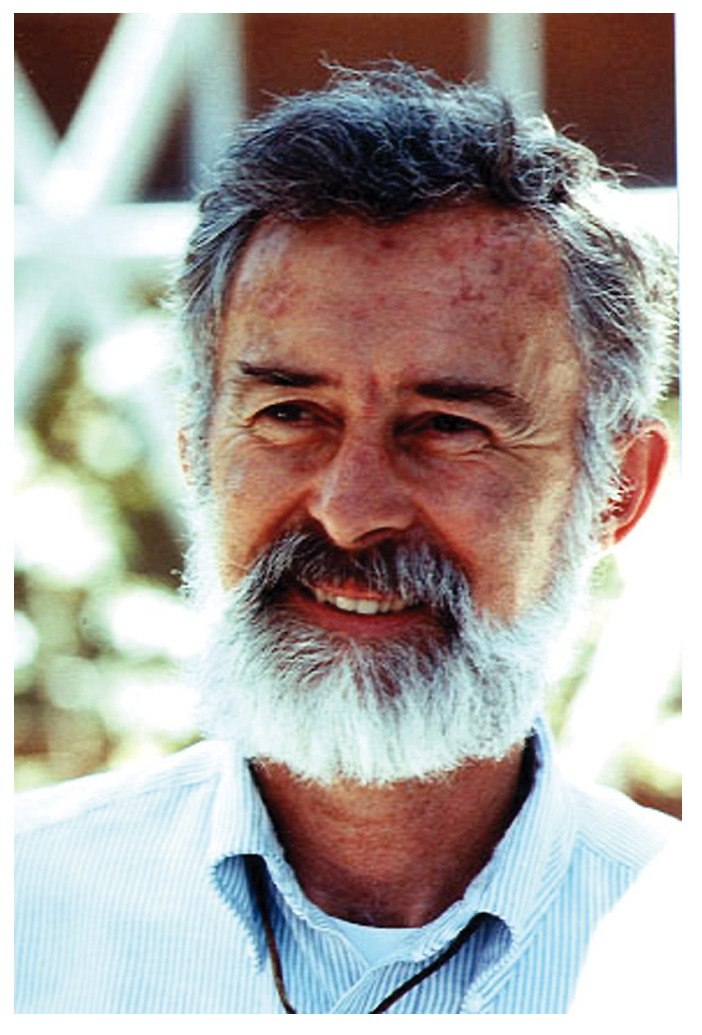

\section{In Memoriam}

Roy Alden Bailey (1929-2003)

Roy A. Bailey received his B.A. in geology from Brown University in 1951 and his M.Sc. from Cornell University in 1953. He was a Fulbright Scholar in New Zealand in 1956, where he met his wife Patrice and began his career-long professional attachments. Roy began his career with the U.S. Geological Survey (USGS) as camp cook and geologic field assistant in New Mexico during the summers of 1950-52, and became a full-time geologist with the USGS in 1953 in Reston, Va. After working 16 years as a geologist, he returned to graduate school at the Johns Hopkins University from 1969 to 1971, completing his Ph.D. in 1978 under the USGS Employee Training Program. His research with the USGS focused primarily on the study of large silicic volcanic systems. His fruitful collaboration with Robert L. Smith and Clarence S. Ross led to the publication of classic papers on resurgent calderas and chemical zonation in magma reservoirs. Roy's principal field efforts involved geologic mapping of Valles Caldera (Jemez Mountains, N.Mex.) and the Long Valley volcanic field in eastern California. Through careful mapping of the volcanic rocks in eastern California, he was able to identify the source of the widespread Bishop Tuff as a large resurgent caldera at the base of the eastern Sierra Nevada escarpment, now known as Long Valley Caldera.

During the 1960s, Roy was an instructor in the National Aeronautics \& Space Administration (NASA)'s Apollo training program, tutoring astronauts in the recognition of lunar volcanic features by comparing them to similar features on the Earth. During 1980-83, he served as coordinator of the USGS Volcano Hazards Program, which was greatly increased in size and complexity after the 1980 eruption of Mount St. Helens, Wash. In this managerial role, he deftly guided the Survey's expanded monitoring and research activities in Hawaii, Alaska, and the conterminous United States. In 1983, he rotated back into a research position, moved to Menlo Park, Calif., in 1984, and resumed his studies of the Long Valley volcanic field, where escalating seismicity and magmatic unrest raised concerns about a possible eruption. He retired in 1995, after 42 years of service, and continued working essentially full time as a Pecora Fellow (1995-97) and as Scientist Emeritus with the USGS Volcano Hazards Team (1997-2003).

Roy was a Fellow of both the Geological Society of America and the Mineralogical Society of America and held membership in the American Geophysical Union and the Commission on Explosive Volcanism of the International Association of Volcanology and Chemistry of the Earth's Interior. Throughout his long and distinguished career, Roy was recognized by his peers for his perceptive geologic observations and exceptional mapping skills. His carefully documented studies of the products and processes of large explosive eruptions contributed to fundamental understanding of the evolution of caldera-forming magmatic systems. 
This page intentionally left blank 


\section{Contents}

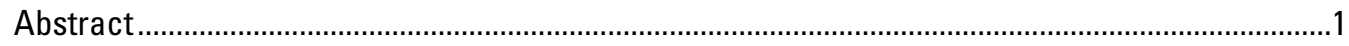

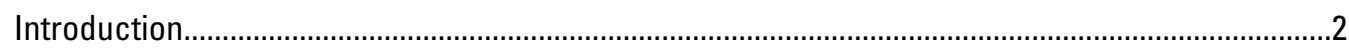

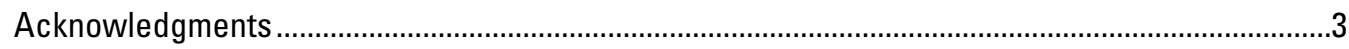

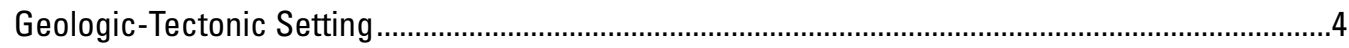

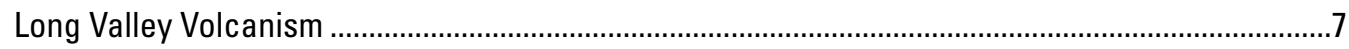

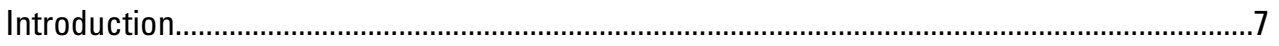

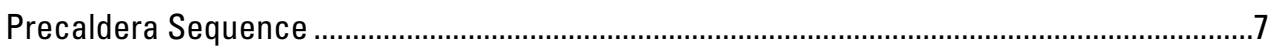

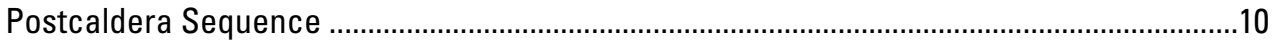

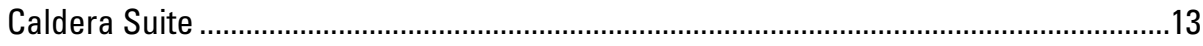

Basalt Enclaves..................................................................................................... 14

Early Intracaldera Basalt-Trachyandesite Lavas ...................................................14

Late Intracaldera Basalt-Trachyandesite Lavas ....................................................14

Extracaldera Basalt-Trachyandesite Lavas ........................................................14

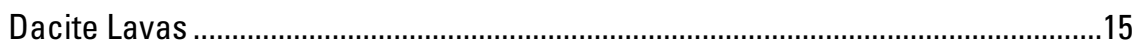

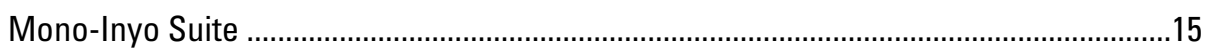

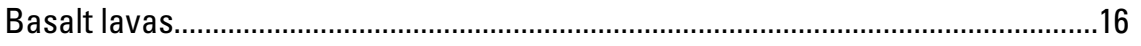

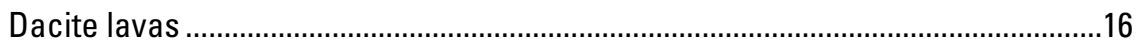

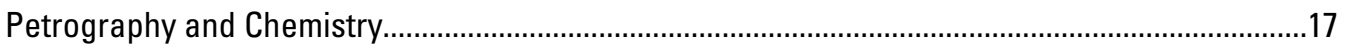

General Relations............................................................................................................... 17

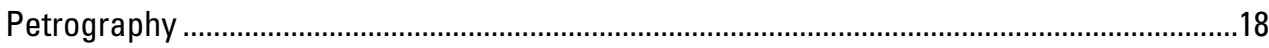

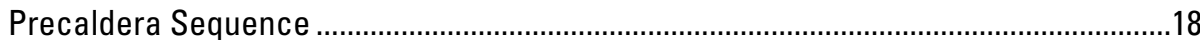

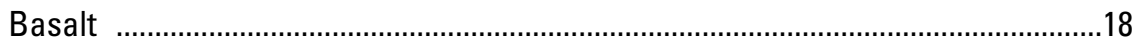

Trachyandesite ............................................................................................. 18

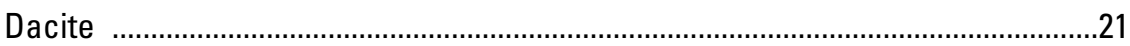

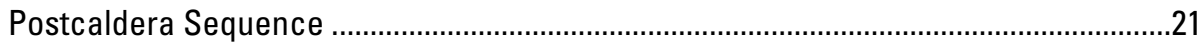

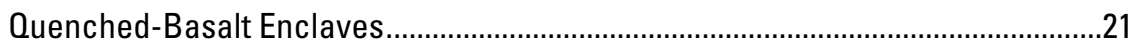

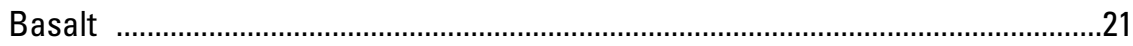

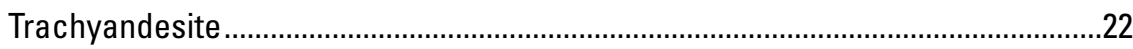

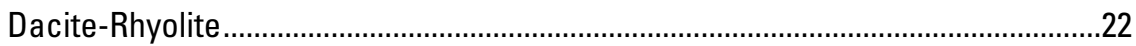

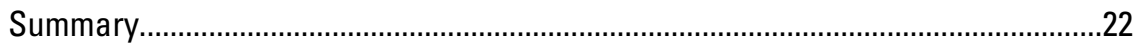

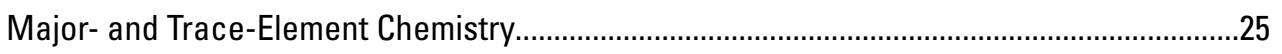

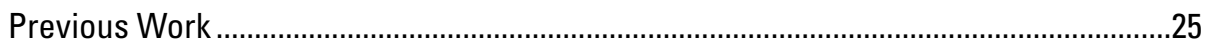

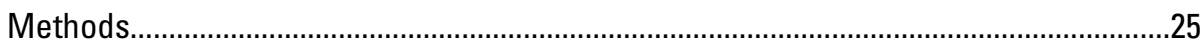

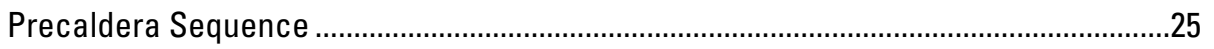

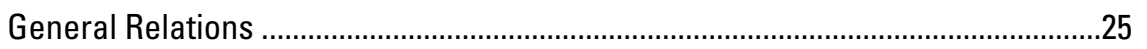

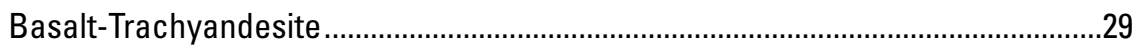

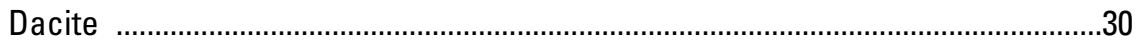

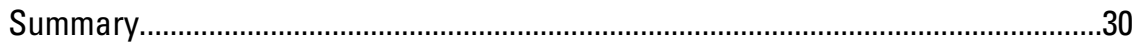

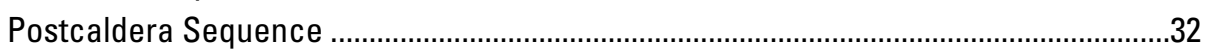

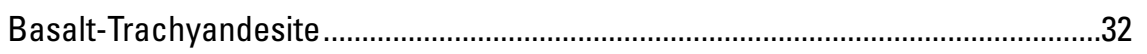

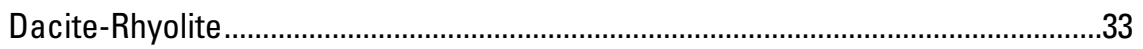

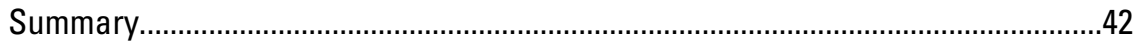

Comparison of the Precaldera and Postcaldera Sequences ...........................................42 


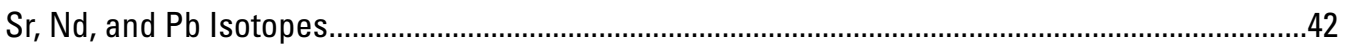

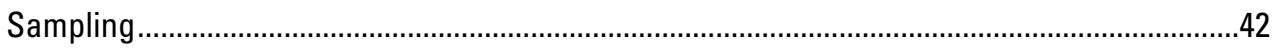

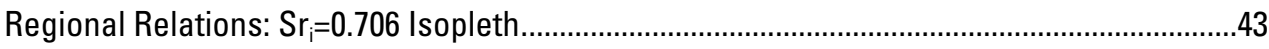

Long Valley General Isotopic Relations ...............................................................................4

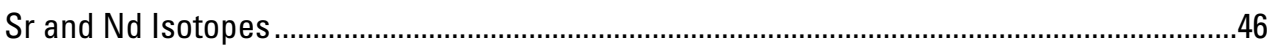

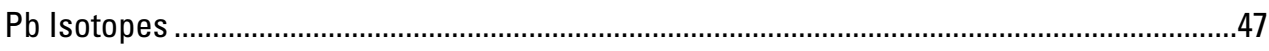

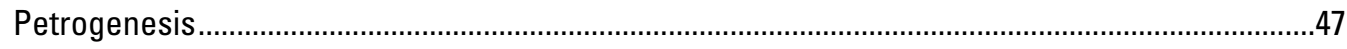

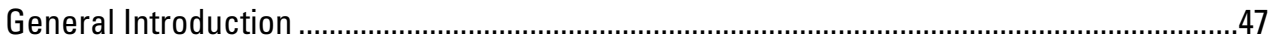

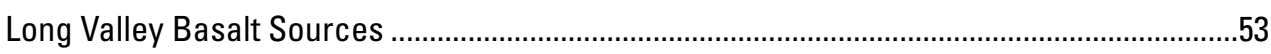

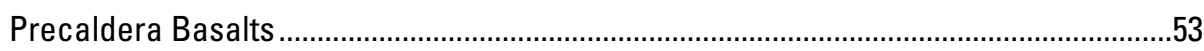

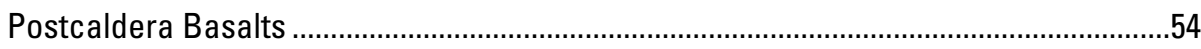

Buttresses and Horseshoe Lake Basalts..........................................................54

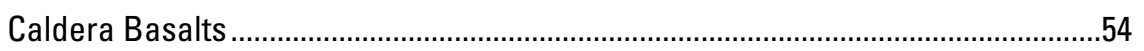

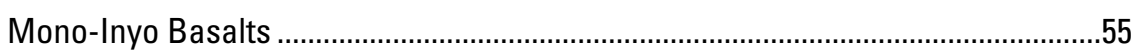

Evolution of the Precaldera Sequence .............................................................................56

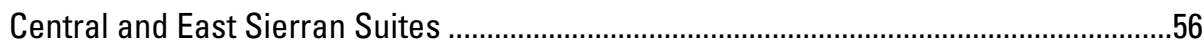

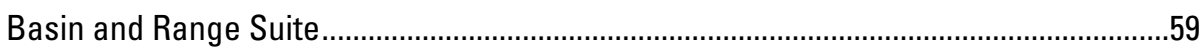

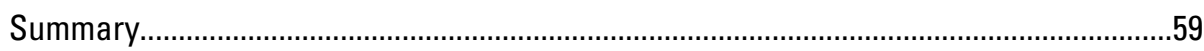

Evolution of the Postcaldera Sequence ...........................................................................5

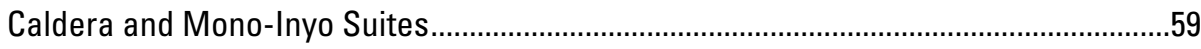

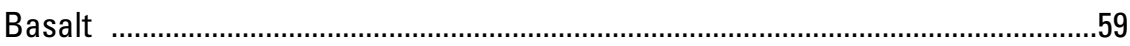

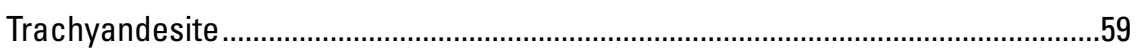

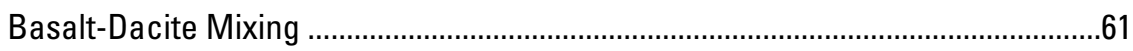

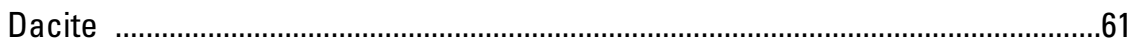

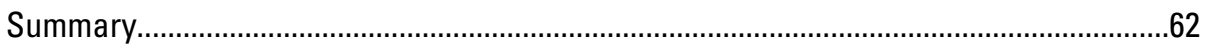

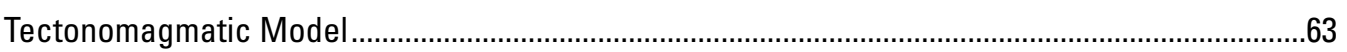

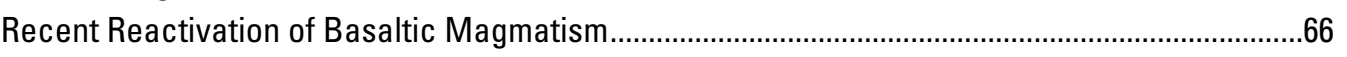

Future Volcanism and Hazards .........................................................................................6

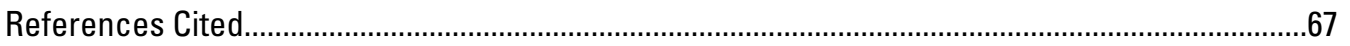

\section{Figures}

1. Sketch map of the Owens Valley Rift, east-central California, showing location and extent of the Long Valley Volcanic Field, as well as the Big Pine and Coso Volcanic Fields

2. Sketch geologic map of central part of the Long Valley Volcanic Field, Calif., showing distribution of precaldera and postcaldera basalt-dacite sequences................6

3. Histograms of number of dated lava flows per 100 k.y. versus time ................................8

4. Sketch geologic map of west moat of Long Valley Caldera, Mammoth Mountain, and Devils Postpile area, Calif. (after Bailey, 1989)........................................................11

5. Sketch geologic map of June Lake-Mono Craters area, Calif ........................................12

6. Sketch geologic map of Mono Lake area, Calif...........................................................13

7. Plots of $\mathrm{K}_{2} \mathrm{O}+\mathrm{Na}_{2} \mathrm{O}$ versus $\mathrm{SiO}_{2}$ contents of precaldera and postcaldera

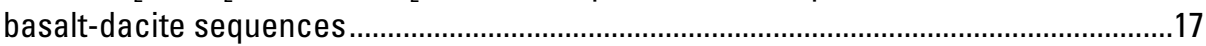

8. $\mathrm{SiO}_{2}$-variation diagrams for the precaldera Central Sierran, East Sierran, and Basin and Range suites.

9. Plots of compositional characteristics of basaltic lavas versus distance from west edge of the Long Valley Volcanic Field, Calif., showing chemical transition through 
the Central Sierran, East Sierran, and Basin and Range suites, across the Sierra Nevada-Basin and Range transition

10. Plots of variations in primitive-mantle-normalized trace-element and chondritenormalized rare-earth-element contents of precaldera mafic lavas.

11. Plots of variations in primitive-mantle-normalized trace-element contents of ocean-island-basalt-like lavas

12. Plots of variations in primitive-mantle-normalized trace-element and chondritenormalized rare-earth-element contents of precaldera trachyandesite-dacite lavas ......33

13. Comparative $\mathrm{SiO}_{2}$-variation diagrams for the Caldera and Mono-Inyo suites of postcaldera sequence

14. Plots of variations in primitive-mantle-normalized trace-element and chondritenormalized rare-earth-element contents of postcaldera basalts

15. Plots of variations in primitive-mantle-normalized trace-element and chondritenormalized rare-earth-element contents of postcaldera dacites and rhyolites.

16. Plots of $\mathrm{Ni}, \mathrm{Cr}$, and $\mathrm{Sc}$ versus $\mathrm{MgO}$ contents of precaldera and postcaldera sequences ....43

17. Plots of $\mathrm{Zr} / \mathrm{Ba}$ ratio versus $\mathrm{SiO}_{2}$ content of precaldera and postcaldera sequences .....43

18. Plots of variations in primitive-mantle-normalized trace-element profiles of precaldera and postcaldera basalts

19. Sketch map of central part of the Long Valley Volcanic Field, Calif., showing location of Long Valley Caldera and distribution of Sr-isotopic samples of precaldera and postcaldera basalts

20. Plots of Sr-versus $\mathrm{Nd}$-isotopic ratios for Long Valley basalts

21. Plots of Sr-isotopic ratio versus $\mathrm{SiO}_{2}$ content of Long Valley basalts

22. Plots of comparative $\mathrm{Sr}$ - and $\mathrm{Pb}$-isotopic ratios of precaldera and postcaldera basalts....48

23. Mantle-normalized trace-element profiles of typical lithospheric- and asthenospheric-mantle-derived melts in the Basin and Range Province

24. Primitive-mantle-normalized trace-element profiles of postcaldera basalts in comparison with representative global basalt types

25. Plots of $\mathrm{Ta} / \mathrm{La}$ versus $\mathrm{La} / \mathrm{Sm}$ ratios of precaldera and postcaldera basalts in relation to other basalts

26. Plot of $\mathrm{Th} / \mathrm{Yb}$ versus $\mathrm{Ta} / \mathrm{Yb}$ ratios for precaldera and postcaldera lavas .58

27. $\mathrm{SiO}_{2}$-variation diagrams illustrating chemical evolution of Caldera basalts and trachyandesites

28. Plot of $\mathrm{Al}_{2} \mathrm{O}_{3}$ versus $\mathrm{SiO}_{2}$ contents for East Sierran lavas and postcaldera rhyolites......62

29. West-to-east cross section from the southern Sierra Nevada across the Basin and Range Province to the Colorado Plateaus Province, showing inferred crust-lithosphere-asthenosphere relations.

30. West-to-east cross sections of the Long Valley Volcanic Field, Calif., showing inferred subcrustal relations

\section{Tables}

1. Stratigraphic units of the Long Valley Volcanic Field, Calif., and their salient features .......9

2-5. Chemical analyses of lavas of:

2. The East Sierran suite . .19

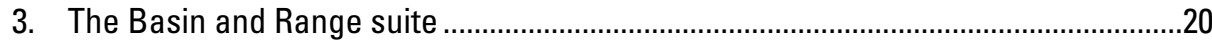

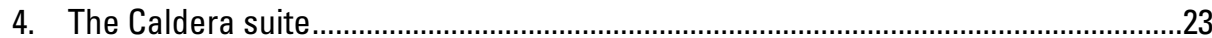

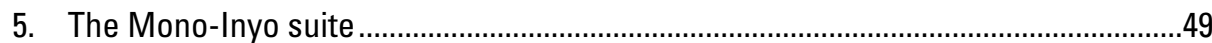

6. Sr-, $\mathrm{Nd}$-, and $\mathrm{Pb}$-isotopic ratios for rock samples from the Long Valley Volcanic Field, Calif 
This page intentionally left blank 


\title{
Eruptive History and Chemical Evolution of the Precaldera and Postcaldera Basalt-Dacite Sequences, Long Valley, California: Implications for Magma Sources, Current Seismic Unrest, and Future Volcanism
}

\author{
By Roy A. Bailey ${ }^{1}$
}

\section{Abstract}

The Long Valley Volcanic Field in east-central California straddles the East Sierran frontal fault zone, overlapping the Sierra Nevada and western Basin and Range Provinces. The volcanic field overlies a mature mid-Tertiary erosional surface that truncates a basement composed mainly of Mesozoic plutons and associated roof pendants of Mesozoic metavolcanic and Paleozoic metasedimentary rocks. Long Valley volcanism began about 4 Ma during Pliocene time and has continued intermittently through the Holocene. The volcanism is separable into two basalt-rhyolite episodes: (1) an earlier, precaldera episode related to Long Valley Caldera that climaxed with eruption of the Bishop Tuff and collapse of the caldera; and (2) a later, postcaldera episode structurally related to the north-south-trending Mono-Inyo Craters fissure system, which extends from the vicinity of Mammoth Mountain northward through the west moat of the caldera to Mono Lake. Eruption of the basalt-dacite sequence of the precaldera basalt-rhyolite episode peaked volumetrically between 3.8 and $2.5 \mathrm{Ma}$; few basalts were erupted during the following $1.8 \mathrm{~m} . \mathrm{y}$. (2.5-0.7 Ma). Volcanism during this interval was dominated by eruption of the voluminous rhyolites of Glass Mountain (2.2-0.8 Ma) and formation of the Bishop Tuff magma chamber. Catastrophic rupture of the roof of this magma chamber caused eruption of the Bishop Tuff and collapse of Long Valley Caldera (760 ka), after which rhyolite eruptions resumed on the subsided caldera floor. The earliest postcaldera rhyolite flows (700-500 ka) contain quenched globular basalt enclaves (mafic magmatic inclusions), indicating that basaltic magma had reentered shallow parts of the magmatic system after a 1.8-m.y. hiatus. Later, at about $400 \mathrm{ka}$, copious basalts, as well as dacites, began erupting from vents mainly in the west moat of the caldera. These later eruptions initiated the postcaldera basalt-rhyolite episode related to the Mono-Inyo Craters fis-

${ }^{1}$ Deceased. sure system, which has been active through late Pleistocene and Holocene time.

This report addresses only the basalt-dacite sequences of the two Long Valley basalt-rhyolite episodes. Contrasting mineralogy and chemistry of the precaldera and postcaldera basaltdacite sequences indicate that these two sequences had different sources and modes of origin. Precaldera basalts are predominantly olivine-augite phyric, with high $\mathrm{MgO}, \mathrm{K}_{2} \mathrm{O}, \mathrm{P}_{2} \mathrm{O}_{5}, \mathrm{Ba}$, $\mathrm{Rb}$, and $\mathrm{Sr}$ contents and low $\mathrm{Al}_{2} \mathrm{O}_{3}, \mathrm{TiO}_{2}$, and $\mathrm{FeO} *$ contents. Most precaldera basalts have modified island-arc-basalt (IAB)-like trace-element signatures and are depleted in highfield-strength elements (HFSEs: Ta, Nb, Ti) and enriched in large-ion-lithophile elements (LILEs: $\mathrm{Rb}, \mathrm{Ba}, \mathrm{K}, \mathrm{Sr}$ ) and lightrare-earth elements (LREEs). Such characteristics for basalts in the Basin and Range Province are generally attributed to a lithospheric-mantle source. Rare ocean-island-basalt (OIB)-like lavas, from a presumed asthenospheric-mantle source, also occur in the precaldera sequence, indicating that both asthenospheric- and lithospheric-mantle melts were erupting simultaneously and in close proximity during precaldera time.

In contrast, most postcaldera basalts are predominantly plagioclase phyric, with higher $\mathrm{Al}_{2} \mathrm{O}_{3}, \mathrm{TiO}_{2}$, and $\mathrm{FeO} *$ contents and lower $\mathrm{MgO}$ and $\mathrm{P}_{2} \mathrm{O}_{5}$ contents. Although they also have LILE-enriched, IAB-like trace-element signatures, they are less depleted in HFSEs and less enriched in LILEs and LREEs than are precaldera basalts. The trace-element signatures of postcaldera basalts closely resemble that of the mafic-lowercrust global average, suggesting that these basalts may have been generated by partial melting of a mafic-lower-crustal source or, alternatively, by mixing of lithospheric-mantle melt with a midocean-ridge-basalt (MORB) mantle component.

Superimposed on these temporal mineralogic and chemical differences are provincial differences related to contrasting tectonic regimes west and east of the East Sierran frontal fault zone, which locally separates the Sierra Nevada and Basin and Range Provinces. In the precaldera sequence, these provincial differences can be grouped into three magmatic suites: a Central Sierran suite, an East Sierran suite, and a 
Basin and Range suite. Central and East Sierran basalts have high $\mathrm{Mg}$ numbers (Mg\#=67-80), $\mathrm{Ce} / \mathrm{Yb}$ ratios, and $\mathrm{Y}$ contents, whereas Basin and Range basalts have lower Mg numbers (Mg\#=58-67), Ce/Yb ratios, and Y contents. These differences are inferred to reflect a thick (40-100 km deep) lithospheric mantle and a garnet peridotite source beneath the Sierra Nevada, and a thinner (30-75 km deep) lithospheric mantle and a spinel peridotite source beneath the western Basin and Range Province. Provincial mineralogic and chemical contrasts also are evident in the more highly evolved precaldera dacites. East Sierran dacites are hornblende-biotite-plagioclase (and some quartz) phyric and relatively enriched in incompatible elements. Basin and Range dacites typically lack biotite phenocrysts; they are hornblende-plagioclase phyric and have lower incompatible-element contents. In addition, the East Sierran suite shows compositional gaps between basalts, trachyandesites, and dacites, wherein most trachyandesites are attributable to mixing of basaltic and dacitic end members of which the dacitic end members were derived by melting of midcrustal to upper-crustal Mesozoic granitoids. The Basin and Range suite, in contrast, shows a more nearly continuous secular trend, with increasing $\mathrm{SiO}_{2}$ contents, wherein basalt fractionated to trachyandesite and dacite, in turn, fractionated from trachyandesite.

In the postcaldera sequence, two temporally and geographically distinct magmatic suites are recognized: an older (50-700 ka) Caldera suite, situated in and near the west moat of Long Valley Caldera; and a younger (<30 ka) Mono-Inyo suite, confined to the axis of the north-trending Mono-Inyo Craters fissure system. Both suites are bimodal, with a conspicuous compositional gap between trachyandesite and dacite but not between basalt and trachyandesite. Compositional trends in postcaldera basalts and trachyandesites, particularly in the Caldera suite, suggest a two-stage evolution involving (1) contamination of parental basalt by assimilation of basement granitoids or by mixing with coeval dacite at midcrustal levels, followed by (2) selective diffusion of $\mathrm{Ba}$ and $\mathrm{K}$ into this contaminated basalt during intimate contact with sanidine- and biotite-rich residual Moat Rhyolite magma (or its congealed equivalent) at shallow crustal levels. Postcaldera dacites and associated low-silica rhyolites, which have significantly lower $\mathrm{Sr}$ - and higher Nd-isotopic ratios than precaldera dacites, were probably derived by partial fusion of mafic lower-crustal rocks and subsequently modified by crystal fractionation.

These relations suggest the following speculative tectonomagmatic model. Since about $4 \mathrm{Ma}$, an asthenosphericmantle welt has been rising through extending and thinning lithospheric mantle along the west edge of the Basin and Range Province, providing sufficient heat to melt and erode the lithospheric mantle to the base of the lower crust. The hiatus in Long Valley basaltic volcanism at 2.5-0.7 Ma, coincident with eruption of precaldera Glass Mountain rhyolites (2.1-0.8 Ma) and formation of the Bishop Tuff rhyoliticmagma chamber, suggests that the chamber formed during an episode of diminished regional extension, which caused ponding of basalt near the crust/lithospheric-mantle interface, resulting in crustal underplating, fusion, and magmatic differentiation. At about $800 \mathrm{ka}$, renewed regional extension allowed injection of basalt into the base of the Long Valley rhyolitic-magma chamber, possibly triggering eruption of the Bishop Tuff. Subsequent repeated brief episodes of crustal extension and basalt influx into the magma chamber probably account for its longevity ( $>1$ m.y.), the frequent mixing and mingling of basaltic and rhyolitic magmas, and a history of concomitant basaltic and rhyolitic eruptions.

The current (post-1980) seismic unrest at Long Valley, accompanied by uplift of the resurgent dome, may signal the onset of a new episode of regional extension and basalt injection into the residual silicic-magma chamber. The post-1989 seismic unrest at Mammoth Mountain, accompanied by 10- to 30-km-deep, long-period earthquakes and copious emission of mantle-derived $\mathrm{CO}_{2}$ and $\mathrm{He}$, is inferred to result from influx of basalt from a deep mantle source, possibly portending a small extracaldera basaltic eruption like that at nearby Red Cones about $5 \mathrm{ka}$. However, with intense seismic swarms continuing episodically in the south moat of the caldera, accompanied by resurgent dome inflation at short-term rates as high as 20 $\mathrm{cm} / \mathrm{yr}$, basaltic or basalt-triggered rhyolitic eruptions within the caldera also are distinctly possible. Nevertheless, available worldwide eruption-frequency data for historically active restless calderas indicate that eruptions have occurred in only 10 of 60 known instances of unrest. Eruptions along the MonoInyo Craters Volcanic Chain at 250- to 700-year intervals over the past $5 \mathrm{k}$.y. indicate that future eruptions there are likely but not necessarily imminent.

\section{Introduction}

Long Valley Caldera and its associated Pliocene to Holocene volcanic field, in central eastern California, straddle the East Sierran frontal fault zone, overlapping the Sierra Nevada and western Basin and Range Provinces. This volcanic field, therefore, is critically situated to provide information and insight into the magmatic and tectonic contrasts and the nature of the crustal transition between these two provinces. In addition, an understanding of the volcanic and magmatic evolution of the Long Valley Volcanic Field is crucial to determining the cause of the current seismic and magmatic unrest that has afflicted the area since 1980 (Bailey, 1983; Hill and others, 1985a, b; Bailey and Hill, 1990). Acceleration of this unrest since 1989, as indicated by increasing uplift of the intracaldera resurgent dome and by sporadic, intense seismic swarms, together with evidence for the influx of mantle-derived mafic magma into the roots of the magmatic system, has prompted a more careful look at the eruptive history and chemical evolution of the entire volcanic field-particularly at the Pleistocene to Holocene sequence, which bears more directly on the type and course of future eruptions.

U.S. Geological Survey (USGS) studies of the Long Valley-Mono Basin area commenced in 1972 as part of the USGS Geothermal Research Program. Between 1972 and 1980, 
effort was focused on geologic, hydrologic, and geophysical studies to determine the origin and economic potential of the associated geothermal system (Muffler and Williams, 1976). Since 1980, however, at the onset of the current seismic and magmatic unrest, research and monitoring have focused on assessing the probability of future volcanic eruptions and on determining the associated potential hazards. The Long Valley Volcanic Field has a 4-m.y. history of volcanic activity. For the past 5 k.y., eruption intervals along the Mono-Inyo Craters Volcanic Chain, which traverses the west moat of the caldera, have ranged in duration from 250 to 700 years, indicating that future eruptions there are likely, though not necessarily imminent.

The current episode of volcanic unrest at Long Valley began in 1978 with an $M=5.8$ earthquake on Wheeler Crest, $12 \mathrm{~km}$ southeast of the caldera. During the following 2 years, seismicity gradually migrated northwestward toward the caldera, culminating in May 1980 with an unprecedented 2-day sequence of four $M=6$ earthquakes, accompanied and followed by hundreds of aftershocks that shook the resort town of Mammoth Lakes (Sherburne, 1980). Since then, the area has been subjected to varying, but nearly continuous, seismic unrest, accompanied by gradual uplift of the resurgent dome in the center of Long Valley Caldera at an average rate of about $2 \mathrm{~cm} / \mathrm{yr}$, but with short-term rates as high as $20 \mathrm{~cm} / \mathrm{yr}$. This uplift was inferred to be caused by injection of new magma into the subjacent Long Valley magma chamber (Ryall and Ryall, 1983; Savage and Clark, 1983). Subsequent seismic, geodetic, and geophysical monitoring and research have substantiated that conclusion and raised concern for possible near-term volcanic eruptions. In 1982, after a swarm of rapidly shallowing earthquakes, the USGS issued a "Notice of Potential Volcanic Hazard" (Miller and others, 1982).

More recent seismic events have intermittently heightened the concern for possible eruptions - in particular, three intense and unusually prolonged earthquake sequences that punctuated the numerous sporadic seismic swarms after 1980: one in 1983 in the south moat of the caldera; another in 1989 beneath Mammoth Mountain; and a third in the south moat, lasting from June 1997 to January 1998. During each of these events, deformation studies (trilateration and leveling; Savage and Cockerham, 1984; Hill and others, 1990; Langbein and others, 1995; D.P. Hill, unpub. data, 1998) and seismic signatures (Julian, 1983; Aki, 1984; Savage and Cockerham, 1984) suggested that magma was being injected as dikes to depths as shallow as $2 \mathrm{~km}$ in the south moat and beneath Mammoth Mountain. The recognition of mantle-derived He in Mammoth Mountain fumaroles (Welhan and others, 1988) and of marked changes in ${ }^{3} \mathrm{He} /{ }^{4} \mathrm{He}$ ratios accompanying regional seismic events (Sorey and others, 1993; Hilton, 1996), together with the 1994 discovery that since 1990 copious amounts of mantle-derived $\mathrm{CO}_{2}$ had been accumulating in soils and escaping from fumaroles around Mammoth Mountain (Farrar and others, 1995), suggested that this magma is basaltic in composition. Corroborating this suggestion was the detection of long-period earthquakes beneath Mammoth Mountain at
10- to 30-km depth (Pitt and Hill, 1994; Hill, 1996); such earthquakes are generally understood to be caused by magma or fluid movement in confined channels (Chouet, 1996).

After the 1989 Mammoth Mountain earthquake sequence and again during the 1997-98 sequence, uplift of the intracaldera resurgent dome increased significantly (Langbein and others, 1993, 1995; D.P. Hill, written commun., 1998), strongly suggesting that new magma, probably basalt rising from a deep mantle source, was recharging and inflating the residual Long Valley rhyolitic-magma chamber, as well as being injected as dikes beneath Mammoth Mountain and the south moat. The likelihood and timing of possible eruptions related to this new influx of magma will depend on the frequency and longevity of its injection into the magmatic system-which, ultimately, may depend on the future course of regional extensional tectonism.

This report is based on long-term, continuing USGS geologic and petrologic studies of Long Valley Caldera and the Mono-Inyo Craters Volcanic Chain (Bailey and others, 1976; Bailey, 1982, 1984, 1989). It describes field relations and the petrographic, chemical, and isotopic characteristics of the precaldera and postcaldera basalt-dacite sequences and discusses their petrogenesis. It outlines the volcanic and chemical evolution of the Long Valley Volcanic Field, relates the current magmatic unrest to past magmatic evolution, suggests possible models for both past volcanism and the current seismicity, and discusses the types of eruption likely to occur in the foreseeable future.

\section{Acknowledgments}

This report includes the results of geologic mapping conducted between 1972 and 1987, while I was ably assisted in the field by Rob Koeppen, Tom Holecek, Fred Wilson, Roy Chaudet, and Marybeth Hughett Price. Bob Sperandio and the late Kerry Dickson provided tireless and competent assistance in the preparation of samples for chemical analysis. All samples were analyzed in the U.S. Geological Survey's chemical laboratories in Reston, Va., Lakewood, Colo., and Menlo Park, Calif.

I am grateful to N.W. Rogers for compiling chemical analyses of the Basin and Range basalts collected by his Newcastle-on-Tyne (U.K.) research group. I also gratefully acknowledge permission by Roy Chaudet and Krishna Sinha to present previously unpublished $\mathrm{Sr}$-isotopic data on East Sierran lavas (table 6).

In preparing the manuscript, I benefited greatly from discussions with Dave Hill, Mike Sorey, Charlie Bacon, Tom Sisson, Art Lachenbruch, Bob Jachens, and George Thompson. Early reviews by Tom Sisson and Julie Donnelly-Nolan, subsequent reviews by Mike Clynne and Charlie Bacon, and later reviews of selected sections by Art Lachenbruch, Ron Kistler, Dave Hill, and Mike Sorey are greatly appreciated. All the reviewers provided constructive suggestions and 
comments that greatly improved the manuscript's content and presentation; however, I accept full responsibility for the final content of this report and for any errors of fact or fancy contained therein. David Ramsey prepared digital versions of the maps and illustrations. Manuel Nathenson and Wes Hildreth provided editorial assistance after the author's death in July 2003.

\section{Geologic-Tectonic Setting}

The Long Valley Volcanic Field (figs. 1, 2) covers an area of about 4,000 $\mathrm{km}^{2}$ at the north end of the Owens Valley Rift, overlapping the central and eastern Sierra Nevada and the western Basin and Range Provinces. ${ }^{2}$ The Long Valley Volcanic Field is the largest and northernmost of three approximately contemporaneous volcanic fields within the Owens Valley Rift, which includes the Big Pine and Coso Volcanic Fields, 70 and $180 \mathrm{~km}$, respectively, to the south. Lavas of all three of these Pliocene/Pleistocene to Holocene volcanic fields have erupted through basement rocks that compose the Sierra Nevada batholith-predominantly Mesozoic granitic-granodioritic plutons and subordinate associated Paleozoic metasedimentary and Mesozoic metavolcanic roof pendants.

Before the onset of Pliocene volcanism, the Long Valley region and most of the Basin and Range Province to the east was an elevated upland with relatively low topographic relief that rose eastward from the Central Valley of California to about 2,100-m elevation. The upland surface was mantled by a Tertiary (Miocene) regolith (Matthes, 1960; Huber, 1981), remnants of which are still preserved locally in the High Sierra south and west of Long Valley. At that time, the East Sierran frontal fault scarp had little or no topographic expression (Matthes, 1939; Christensen, 1966; Huber, 1981), and streams east of the present scarp flowed generally westward down the now-oversteepened dip slope of the Sierra Nevada to the Central Valley.

Owens Valley rifting and volcanism began about $4.5 \mathrm{Ma}$, shortly after opening of the Gulf of California (Larsen and others, 1968; Ward, 1991) and uplift of the Sierra Nevada crest (Huber, 1981), which apparently coincided also with accelerated spreading of the East Pacific Rise (Atwater and Molnar, 1973), as well as of the East Scotia Ridge spreading center (Barker, 1995). Thus, the initiation of Owens Valley rifting and volcanism is related to a global episode of accelerated plate motion. Complicating local tectonic relations include

${ }^{2}$ Leeman (1982), Menzies and others (1983), and Fitton and others (1988) applied the term "Sierra Nevada Province" or "Sierran subprovince" (in a magmatic sense) to the part of the Basin and Range Province immediately east of the Sierra Nevada; Fitton and others (1991) referred to this region as the "Western Great Basin province." In this report, the term "Sierra Nevada Province" is used in the traditional structural/geographic sense but is restricted to the uplifted Sierra Nevada range, while the term "Basin and Range Province" is applied locally to the region just east of the East Sierran frontal fault, as well as to the entire block-faulted region of the Western United States.
(1) westward encroachment on the Owens Valley region by classic Basin and Range extensional block faulting, which has been spreading laterally eastward and westward from central Nevada over the past 17 m.y. (Eaton, 1982); and (2) rightlateral shear stress sympathetic to the northwest-trending San Andreas Fault system that was initiated at the California coast about $29 \mathrm{Ma}$ and has since migrated inland to the Walker Lane in eastern Nevada (Savage and others, 1995). Right-lateral offset was the dominant motion on the north-northwest-trending Owens Valley Fault during the 1872 Lone Pine earthquake (Beanland and Clark, 1994). Recent earthquakes on apparent conjugate north- to north-northeast-trending faults in the High Sierra south of Long Valley Caldera show complementary left-lateral displacement mechanisms (Savage and Cockerham, 1984; Hill and others, 1985b).

The Long Valley Volcanic Field is near the intersection of two major structural trends: (1) the north-northwest-trending East Sierran frontal fault zone; and (2) the geophysically defined, nearly orthogonal, northeast-trending faults bounding Mono Basin (Pakiser, 1970) and the Excelsior Mountains, which constitute the Mono Basin-Excelsior Mountains Fault zone (Savage and others, 1995). This northeastward trend, which is dominant in the basins and ranges of northwestern Nevada, is relatively uncommon in the Long Valley region but is evident in the faults truncating the north end of the White Mountains, bounding Deep Springs Valley, and transecting the Volcanic Tableland. Long Valley Caldera also lies within a major left-stepping offset in the East Sierran frontal fault scarp, commonly referred to as the "Mammoth embayment." This offset is just south of the northeast-trending Mono Basin-Excelsior Mountains Fault zone. The intersection between these northwest- and northeast-trending structures also marks the site of a major northeastward offset in the historically active north-trending Central California Shear Zone and its apparent northward extension, the Central Nevada Seismic Zone (Savage and others, 1995, fig. 1). The nearcoincidence of these structural and seismic elements probably constitutes a region of exceptional crustal weakness that has allowed passage of mafic magma from the mantle to the surface and provided space for the generation of the younger silicic-magma chambers of the Long Valley Volcanic Field. Further evidence for structural control of the volcanic field is suggested by the distribution of precaldera mafic lavas, particularly in the west half of the field. West of the present Sierra Nevada crest, most Long Valley mafic vents and flows are confined to a triangular topographic depression that is bounded by the range crest, west-trending Kaiser Ridge, and northeast-trending Chiquito Ridge (fig. 1). Although this depression, drained by the upper San Joaquin River headwaters, appears to be erosional in origin (Matthes, 1960), confinement of nearly all the Pliocene volcanic vents within this triangle suggests that the depression is structurally controlled. Although no bounding faults have been recognized, the basin, with its eastern apex at a major offset at the East Sierran frontal fault zone, suggests a depressed triangular fault block within the Sierra Nevada dip slope. 


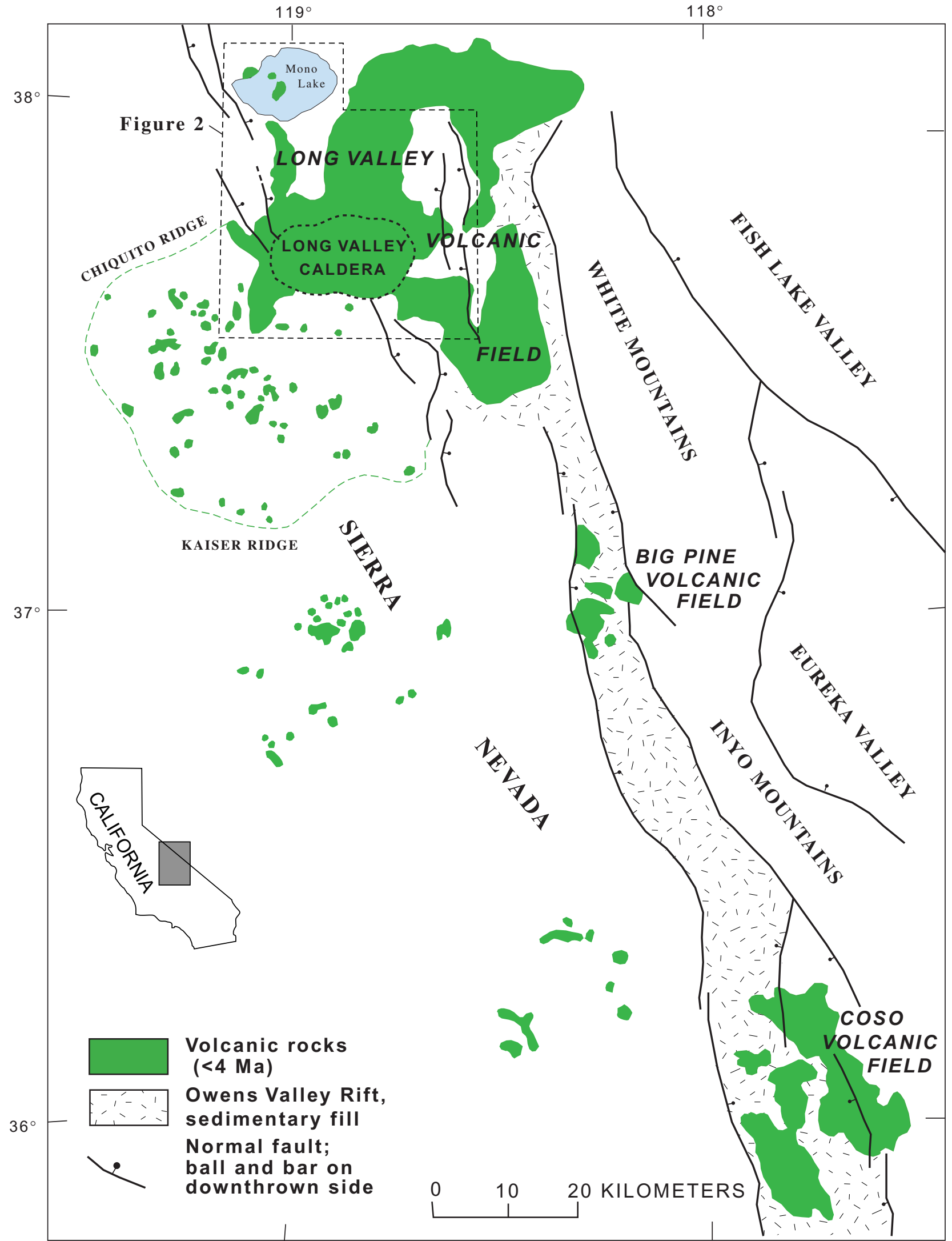

Figure 1. Sketch map of the Owens Valley Rift, east-central California, showing location and extent of the Long Valley Volcanic Field, as well as the Big Pine and Coso Volcanic Fields. Dashed line encloses scattered high-K lavas of the central Sierra Nevada (Van Kooten, 1980), inferred to be part of the Long Valley Volcanic Field. 


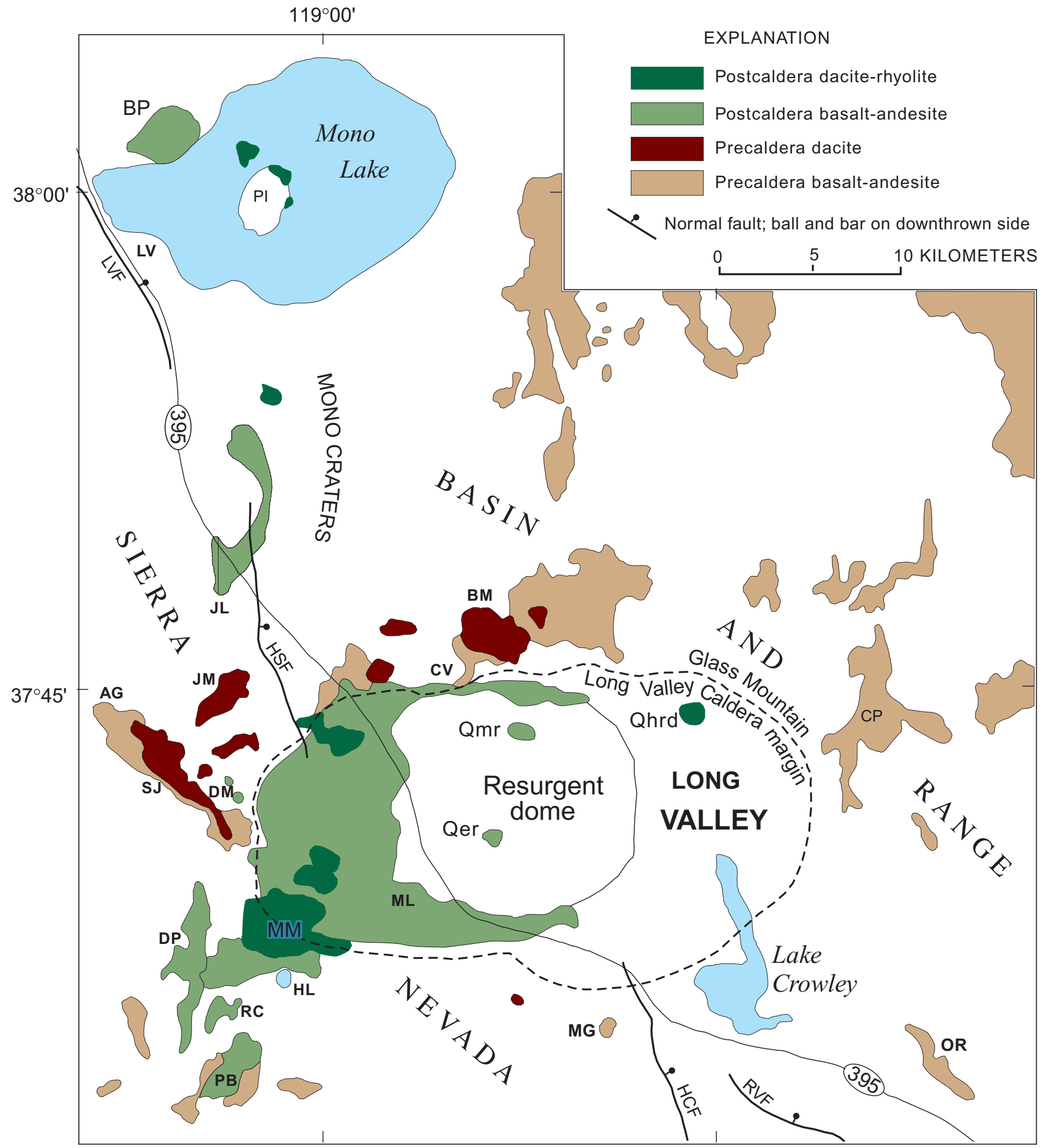

Figure 2. Sketch geologic map of central part of the Long Valley Volcanic Field, Calif. (fig. 1), showing distribution of precaldera and postcaldera basalt-dacite sequences. AG, Agnew Meadow; BM, Bald Mountain; BP, Black Point; CP, Cone Peak; CV, Crestview; DM, Deadman Pass; DP, Devils Postpile; HL, Horseshoe Lake; JL, June Lake; JM, June Mountain; LV, Lee Vining; MG, McGee Mountain; ML, Mammoth Lakes; MM, Mammoth Mountain; OR, Owens River Gorge; PI, Paoha Island; RC, Red Cones; SJ, San Joaquin Ridge. Sierra Nevada east-frontal faults: HCF, Hilton Creek Fault; HSF, Hartley Springs Fault; LVF, Lee Vining Fault; RVF, Round Valley Fault. Qer, basaltic enclave-bearing Early Rhyolite dome; $0 \mathrm{mr}$, basaltic enclave-bearing Moat Rhyolite. 
Tectonism and volcanism within the Owens Valley have continued episodically from Pliocene through Holocene time. Recent major seismic swarms on faults bounding the northern Owens Valley (the Round Valley Fault in 1984 and the White Mountain [Chalfant Valley] Fault in 1986), together with a general increase in regional seismicity (Ryall and Ryall, 1981) and in deformation rate since 1978 (Savage and others, 1995), suggest that the rift is undergoing the onset of a new episode of extension. According to Raleigh and others (1982), a coeval post-1978 increase in seismicity also has been evident along the San Andreas Rift zone.

Formation of the East Sierran frontal fault scarp and the Owens Valley Rift coincided approximately with the inception of mafic volcanism at Long Valley. Many of the major faults crossing the region, including the East Sierran frontal fault scarp, are growth faults, displacing early mafic lava flows as much as $1,000 \mathrm{~m}$ but younger units only a few tens of meters. Thus, faulting and volcanism along the west edge of the Basin and Range are contemporaneous and intimately related. Although the larger, older fault scarps within the volcanic field trend generally northwest, parallel to the East Sierran frontal fault zone, many younger, smaller and shorter faults trend north-northeast to northeast. The Mono-Inyo Craters Volcanic Chain exhibits this north-northeastward trend, as does a conspicuous set of joints and young faults in basement rocks of the region, some showing 2- to 3-m displacement of late Pleistocene glaciated bedrock surfaces. Many recent seismic epicenters in the Sierran block south of the caldera are aligned along such north-northeast-trending faults (see Hill and others, 1985b, fig. 8). The age of the Mono-Inyo vents along these north-northeast-trending fissures and faults suggests a change in the local extensional-stress direction from northwestsoutheast to west-east in the past $30 \mathrm{k} . \mathrm{y}$. However, although north-northeast-trending structures seem to be most recently active in the volcanic field, young Long Valley volcanic vents are not consistently aligned along them, nor are older vents consistently aligned northwest, indicating that both trends have been exploited by rising magma throughout the life of the volcanic field (see Bailey, 1989, supp. maps C, D).

\section{Long Valley Volcanism}

\section{Introduction}

Long Valley volcanism, which began about $4 \mathrm{Ma}$ in the Pliocene and has continued through the Holocene (Bailey and others, 1976; Bailey, 1989), includes (1) an episode of a precaldera basalt-trachyandesite-dacite-rhyolite volcanism (4.0-0.8 Ma) (fig. 2) that climaxed with eruption of the Bishop Tuff and formation of Long Valley Caldera at $760 \mathrm{ka}$, and (2) an episode of a postcaldera basalt-trachyandesite-dacite-rhyolite volcanism (400 ka-Holocene) that is structurally related to the north-trending Mono-Inyo Craters fissure system (fig. 2). The second episode temporally overlapped extrusion of the intracaldera Early and Moat Rhyolites (700-100 ka). This report focuses primarily on the petrologic and chemical differences within and between the precaldera and postcaldera basalt-dacite sequences of these basalt-rhyolite episodes and on their magmatic and tectonic implications.

Eruption of the precaldera basalt-dacite sequence climaxed between 3.8 and $2.5 \mathrm{Ma}$ (fig. 3), with eruption of the more evolved dacitic lavas late in this interval. Few, if any, lavas of basaltic-dacitic composition were erupted during the following $1.8 \mathrm{~m} . \mathrm{y}$. (2.5-0.7 Ma), when volcanism was dominated by eruption of the Glass Mountain rhyolites and formation of the Long Valley (Bishop Tuff) magma chamber. Mafic lava did not reappear in Long Valley until immediately after eruption of the 760-ka Bishop Tuff and collapse of the caldera. Mafic lava first appeared as quenched basalt enclaves in the 700- to 500-ka intracaldera Early and Moat Rhyolites (units Qer, Qmr, fig. 2) ${ }^{3}$ and later, about $400 \mathrm{ka}$, as basalt-trachyandesite flows in the west moat of the caldera. This hiatus in mafic volcanism between 2.5 and $0.7 \mathrm{Ma}$ was clearly a regional rather than local phenomenon because coeval hiatuses in mafic volcanism also occurred in both the Coso and Cima Volcanic Fields far to the south (Novak and Bacon, 1986; Farmer and others, 1995), suggesting that volcanic activity along the Owens Valley Rift is linked to or influenced by regional tectonic stresses. As discussed below, the lavas preceding and succeeding this hiatus in Long Valley mafic volcanism have significantly different mineralogic and chemical signatures, suggesting that the precaldera and postcaldera sequences were derived from different magmatic sources and evolved by markedly different magmatic processes.

\section{Precaldera Sequence}

The precaldera sequence includes the widespread basalt-trachyandesite flows (unit Tba, fig. 2) extending from the Adobe Hills (Gilbert and others, 1968; Lange and others, 1993) in the northeast to the central Sierra Nevada in the southwest (fig. 1), encompassing the Central Sierran ultrapotassic basanite-tephrite lavas studied by Van Kooten (1980, 1981). Peripheral to and within the present site of Long Valley Caldera, these basalt-trachyandesite lavas evolved to more silicic dacite domes, flows, and tuffs (units Tbm, Tsjd, Tsjt, fig. 2), now preserved mainly on the north and northwest caldera rim in the vicinity of Bald Mountain and San Joaquin Ridge.

Notable differences in form and distribution of the more mafic lavas are evident west and east of the present Sierra Nevada crest: those to the west form small scattered vents with flows of limited volume and extent, whereas those to the east are more voluminous and commonly form broad lava shields and plateaus. This contrast also is evident farther south along the Sierra Nevada, where, near the Big Pine and Coso Volcanic

${ }^{3}$ Unit symbols in figures 4 through 6 correspond to those on the geologic map of Long Valley by Bailey (1989). 


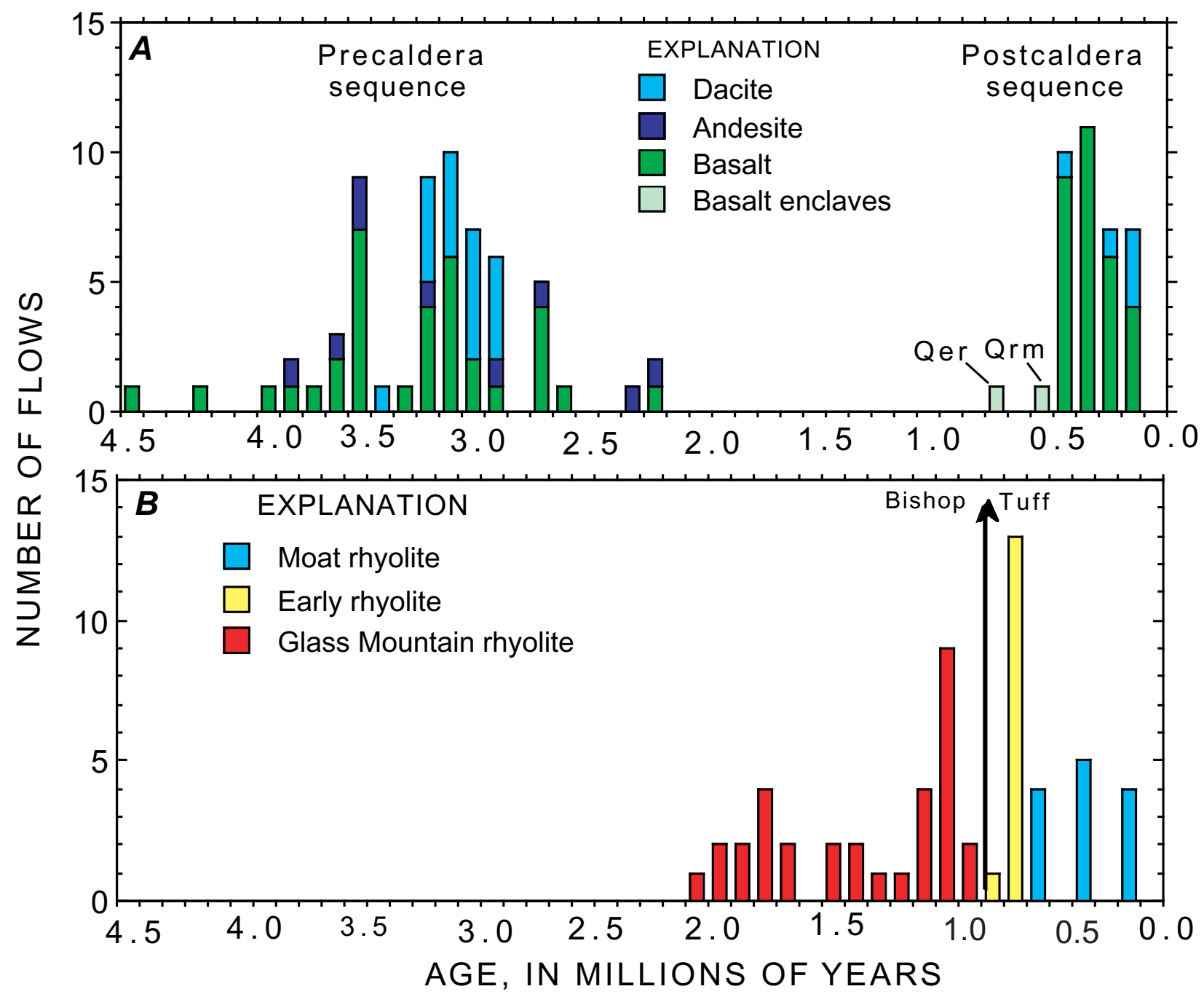

Figure 3. Histograms of number of dated lava flows per 100 k.y. versus time. $A$, Basalt, trachyandesite, and dacite lavas. $B$, Rhyolite lavas. Note hiatus in mafic volcanism (fig. $3 A$ ) during eruption of the Glass Mountain rhyolite (fig. 3B). Qer, basaltic enclave-bearing Early Rhyolite; Qmr, basaltic enclave-bearing Moat Rhyolite. Note that number of radiometrically dated flows does not strictly correspond to volume of erupted flows within individual age spans.

Fields, vents and flows in the High Sierra are few and limited in extent, whereas those to the east in the Owens Valley are more voluminous and extensive (fig. 1). This contrast may be caused by differences in magma source depth related to the thickness of the lithosphere beneath the Sierra Nevada and Basin and Range Provinces-lavas in the west erupting from greater depth through the relatively thick Sierran basement, and those in the east erupting from shallower depth through the tectonically thinned and more fractured Basin and Range basement. Another factor may be that greater degrees of partial melting accompanying rapid thinning of the Basin and Range lithosphere produced greater volumes of magma. These morphologic and volumetric differences between lavas erupted in the Sierra Nevada and the Basin and Range Provinces are accompanied by mineralogic, chemical, and isotopic differences that further distinguish the precaldera lavas west and east of the East Sierran frontal fault zone. These provincial differences permit subdivision of the precaldera sequence into three geographic suites (from west to east): a Central Sierran suite, an East Sierran suite, and a Basin and Range suite (table 1), as discussed in detail below.

The precaldera lavas described in this study were collected mainly within $10 \mathrm{~km}$ of the Long Valley Caldera rim. As indicated above, however, chemically and temporally related lavas extend as far as $40 \mathrm{~km}$ southwestward into the central Sierra Nevada, as well as northeastward to Cowtrack Mountain and the Adobe Hills (fig. 1). Chemical and isotopic data on ultrapotassic lavas of the Central Sierran suite were reported by Van Kooten $(1980,1981)$ and Moore and Dodge (1980). Few data are available for the Adobe Hills lavas, which, though apparently similar in age, may constitute a separate volcanic subfield. These lavas compose a thick sequence of 3- to 4-Ma basaltic-trachyandesitic flows that thin laterally and are interbedded with coarse-grained stream deposits, suggest- 
Table 1. Stratigraphic units of the Long Valley Volcanic Field, Calif., and their salient features.

[Diagnostic phenocrysts (parentheses, present in minor amounts): aug, augite; bio, biotite; diop, diopside; hbl, hornblende; hyp, hypersthene; leuc, leucite; ol, olivine; phlog, phlogopite; plag, plagioclase; pyx, pyroxene (hyp+aug); san, sanidine; qtz, quartz. Do., ditto]

\begin{tabular}{|c|c|c|c|c|c|}
\hline Suite & $\begin{array}{l}\text { Map unit/locality } \\
\text { (figs. } 4,5,6 \text { ) }\end{array}$ & $\begin{array}{l}\text { Age } \\
\text { (Ma) }\end{array}$ & $\begin{array}{l}\text { Diagnostic } \\
\text { phenocrysts }\end{array}$ & $\begin{array}{l}\text { Phenocrysts } \\
\text { (vol pct) }\end{array}$ & Comments \\
\hline \multicolumn{6}{|c|}{ Postcaldera sequence } \\
\hline \multirow[t]{6}{*}{ Mono-Inyo- } & 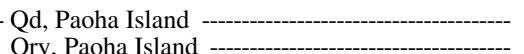 & $\begin{array}{c}0.0002 \\
0002-0.0006\end{array}$ & 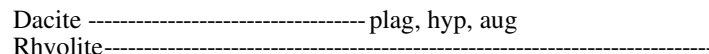 & $1-5$ & --- \\
\hline & Qri, Inyo Craters rhyolite 1 & $\begin{array}{l}.0002-0.0006 \\
.0006 \\
005\end{array}$ & $\begin{array}{l}\text { Ro } \\
\text { do }-1-1\end{array}$ & 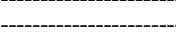 & 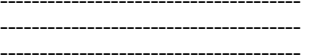 \\
\hline & 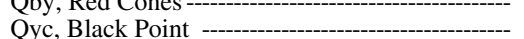 & $\begin{array}{l}.005 \\
.013\end{array}$ & & $1-5$ & - - - \\
\hline & Qa1, Qa2, June Lake & $.025 ?-0.030$ & do - plag, ol, aug & $1-5$ & --- \\
\hline & Qro, Qry: Mono Craters rhyolite ${ }^{1}$--_---_- & $.0002-0.035$ & Rhyolite--_-_-_-_---olag, hyp & $0-1$ & --- \\
\hline & Qpd, Mono Craters, Paoha Island------------- & $.1 ?$ & Porphyritic dacite ------------ plag, ol, aug & $5-10$ & Basalt enclaves. \\
\hline \multirow{18}{*}{ Caldera --- } & - Qya ---1- & $<.025 ?$ & Trachyandesite-_-_-olag, ol & $0-1$ & --- \\
\hline & Qqm2, northwest moat & $<.05 ?$ & Trachydacite-- plag, hbl, bio, pyx (san, qtz) & $20-30$ & Basalt enclaves. \\
\hline & Qrm2, Mammoth Mountain, Lincoln Peak ------- & .05 & Rhyolite--- plag, san & $5-10$ & \\
\hline & Qqm, Mammoth Mountain, west moat ---- & $>.05-<0.25 ?$ & Trachydacite-_- & $25-50$ & Basalt enclaves. \\
\hline & 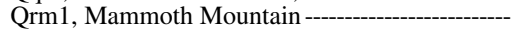 & $.212-0.256 ?$ & Rhyolite--_- bio, aug & $0-5$ & --- \\
\hline & Qaq, west moat, Devils Postpile --_- & .1 & Aphyric trachydacite ---o--o--(plag, hyp, aug) & $5-10$ & --- \\
\hline & Qpb, Horseshoe Lake, west moat----------- & .1 & Porphyritic basalt-- ol, aug (plag) & $5-10$ & --- \\
\hline & Qob, Buttresses -- & $.2 ?$ & do - ol, aug & $5-10$ & --- \\
\hline & Qa, west moat, extracaldera & $.1-0.4$ & Trachyandesite-_-_-_-_-_plag, ol & $0-1$ & Granitoid xenoliths. \\
\hline & Qab, west moat, extracaldera ----о--о--о- & $.1-0.4$ & Trachybasalt - & $0-1$ & Do. \\
\hline & Qgb, west moat -- & .4 ? & Glomeroporphyritic basalt ------- plag, ol & & --- \\
\hline & Corehole Inyo-4, groups I-V - & $.15-0.415 ?$ & Basalt-trachyandesite-1- & & -See Vogel and others (1994) \\
\hline & $\mathrm{Qb}(\mathrm{mr})$, in Moat Rhyolite-1- & .5 & Basalt enclaves-m---microphyric ol, aug & $0-1$ & --- \\
\hline & Qb(er), in Early Rhyolite-- & .68 & do - & $0-1$ & --- \\
\hline & Qhrd, northeast moat- & $.7 ?$ & 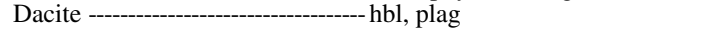 & $20-30$ & --- \\
\hline & 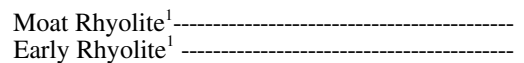 & $\begin{array}{l}.1-0.5 \\
.65-0.75\end{array}$ & 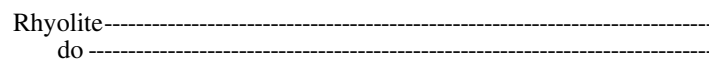 & & \\
\hline & Bishop Tuff ${ }^{1}$--о-о- & .76 & do --- & & \\
\hline & 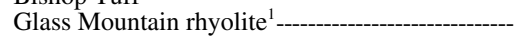 & $.8-2.1$ & do ---.. & & \\
\hline & & & Precaldera sequence & & \\
\hline \multirow{3}{*}{ Basin and $\mathrm{R}$} & - Tbm--ен & $?$ & Dacite & $10-15$ & Lacks mafic enclaves. \\
\hline & Tba--1- & $3.1-3.2$ & Trachyandesite--------------hbl, plag (ol, aug) & $20-50(5-15)$ & --- \\
\hline & Tba--- & $3.1-3.2$ & Alkali olivine basalt -----------ol, aug & $5-10$ & --- \\
\hline \multirow{3}{*}{ East Sierran- } & 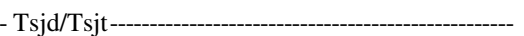 & $2.7-3.1$ & 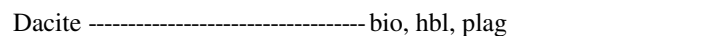 & $30-50$ & Coarse mafic enclaves. \\
\hline & Tba--o- & $3.1-3.2$ & Trachyandesite---_-_-ol, aug, hyp (plag) & $1-10$ & --- \\
\hline & Tba---- & $3.1-3.2$ & Alkali olivine basalt ---_-_------ol, aug (plag) & $5-10$ & --- \\
\hline \multirow{4}{*}{ Central Sier } & - Tba-- & $3.3-3.8$ & Trachyandesite--- & n.d. & --- \\
\hline & Tba-----о-о-о-о-о-о-о-о-о-о-о-о-о-о-о-о-о-о-о-о-о-о-о-о- & $3.3-3.8$ & Alkali olivine basalt ----------ol, diop, plag (san) & n.d. & Rare mantle xenoliths. \\
\hline & 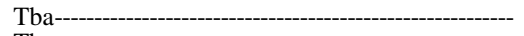 & $3.3-3.8$ & Potassic olivine basalt----------- diop, ol, san (leuc, plag, phlog) & n.d. & --- \\
\hline & 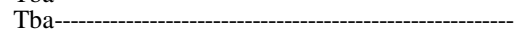 & $3.3-3.8$ & Ultrapotassic basanite ----------san, diop, ol (phlog, leuc) & n.d. & --- \\
\hline
\end{tabular}

${ }^{1}$ Unit not discussed in this report. 
ing that they initially filled a Pliocene basin (Gilbert and others, 1968; Lange and others, 1993). Presently, however, they form an uplifted east-trending anticlinal ridge that is broken by a system of hinged northwest- and northeast-striking normal faults, which, in turn, are cut by numerous smaller, younger (possibly active), east-trending normal faults that suggest active gravitational sliding on the anticlinal flanks. The Adobe Hills are the locus of numerous scattered, small to moderate $(M=1-5)$ earthquakes, with hypocenters localized within a gently east dipping tabular zone at $15-$ to $20-\mathrm{km}$ depth (A.S. Ryall, Jr., oral commun., 1982). The Adobe Hills lavas possibly were fed initially by a Stillwater-like sill complex that is currently being reinflated by influx of new magma; however, owing to its remoteness and difficult access, little is known about heat flow or active deformation in the area.

In the proximity of Long Valley Caldera (fig. 2), the main precaldera basalt-trachyandesite eruption sites are (clockwise from the southwest) near Pumice Butte and at Deadman and Agnew Passes on San Joaquin Ridge, near Crestview and Bald Mountain on the north rim, and at Cone Peak on the east rim; on the southeast, vents occur in the upper Owens River Gorge and on the north shoulder of McGee Mountain. The thickest (450 m thick) of these sequences is at Agnew Pass on San Joaquin Ridge, where early mafic lavas spilled into steepwalled canyons, damming them and forming lakes into which subsequent lavas flowed, producing masses of pillow lava and palagonite breccia. Other examples of precaldera canyon-filling pillowed lavas occur at Clark Lakes and on the east wall of San Joaquin Canyon near Pumice Butte. The longest (10 km long) precaldera flows erupted from Cone Peak on the east rim of the caldera and flowed eastward across the site of the Black and Benton Ranges before their uplift, faulting, and tilting.

Typically, these proximal mafic lavas include a lower sequence of thin (1-3 m thick) basalt flows overlain by a few thicker (10 m thick) trachyandesite flows. At a few sites (near Pumice Butte, San Joaquin Ridge, June Mountain, and Bald Mountain), these mafic flows (unit Tba, fig. 2) are overlain by thick dacite domes, flows, and tuffs (units Tbm, Tsjd/t, fig. 2). Presumably, similar basalt-dacite flows are buried within the caldera, but only one of four deep intracaldera drill holesIDFU 44-16 in the west moat (Suemnicht and Varga, 1988) has intersected any significant thickness $(475 \mathrm{~m})$ of precaldera lavas before penetrating Sierra Nevada basement (Paleozoic metasedimentary rocks at the drillsite). This apparent paucity of precaldera lavas within the caldera may be due to precaldera erosion, dispersion of precaldera vents, or fortuitous intersection of topographic highs in the irregular precaldera Sierran basement by most of the drill holes.

The precaldera volcanic episode also includes the high$\mathrm{SiO}_{2}$ rhyolite dome-flow complex of Glass Mountain on the northeast rim of the caldera, as well as the Bishop Tuff, widely distributed around the caldera as welded pyroclastic flows (ignimbrite). The rhyolites of Glass Mountain were mapped by Metz and Bailey (1993), and their chemical and isotopic compositions were described by Metz and Mahood (1985, 1991), Halliday and others (1989), Davies and others (1994), and
Davies and Halliday (1998). Evidence bearing on the longevity and depth of their source magma chamber was discussed by Sparks and others (1990), Halliday (1990), and Mahood (1990). The Bishop Tuff was first mapped and described by Gilbert (1938), Sheridan (1965), and Hildreth (1979), and Wilson and Hildreth $(1997,1998)$ later amplified its stratigraphy and chemistry. Neither the rhyolite of Glass Mountain nor the Bishop Tuff is described or discussed here except incidentally.

\section{Postcaldera Sequence}

After the collapse of Long Valley Caldera, rhyolite continued to erupt as domes, flows, and tephra on the caldera floor, creating the Early Rhyolite and Moat Rhyolite formations between 700 and $100 \mathrm{ka}$ (Bailey and others, 1976; Bailey, 1989). Heuman and Davies (1997) described the chemical evolution of these intracaldera rhyolites. The postcaldera basalt-dacite lavas coeval with the Early and Moat rhyolites were erupted mainly from vents within and adjacent to the west moat of the caldera. Most of these vents are aligned along fissures that constitute the north-south-trending Mono-Inyo Craters fissure system, which extends $80 \mathrm{~km}$ southward from Mono Lake through Mammoth Mountain (fig. 2) to Mono Hot Springs (35 km south of Mammoth Mountain, near Lake Thomas Edison). The basalt-dacite lavas of this postcaldera sequence are distinguishable on the basis of age, distribution, and chemistry as two distinct basalt-dacite suites (table 1): an older (60-680 ka) Caldera suite and a younger (0.2-30 ka) Mono-Inyo suite. The Caldera suite includes lavas within and immediately southwest of Long Valley Caldera, whereas the Mono-Inyo suite is more narrowly confined to the axis of the Mono-Inyo Craters Volcanic Chain. Both suites were erupted along the Mono-Inyo Craters fissure system. (Note the distinction between the "Mono-Inyo Craters fissure system," the "Mono-Inyo Craters Volcanic Chain," and the "MonoInyo suite," the last of which is geographically and temporally more restricted and based on distinctive chemical criteria.) Miller (1985) and Sieh and Bursik (1986) outlined the eruptive history of the rhyolite domes, flows, and tephras of the Mono-Inyo Craters Volcanic Chain, and Sampson and Cameron (1987) and Kelleher and Cameron (1990) described the chemical evolution of these rocks.

The earliest postcaldera mafic magma appeared as quenched enclaves in one 680-ka Early Rhyolite lava and in one 500-ka Moat Rhyolite unit (units Qer, Qmr, fig. 2). Voluminous mafic lava flows first appeared about $415 \mathrm{ka}$ in the west moat and persisted until about $60 \mathrm{ka}$. Between 250 and $100 \mathrm{ka}$, these mafic eruptions spread southwestward outside the caldera to Horseshoe Lake (unit Qpb, fig. 4), Pumice Butte (unit Qa), Mammoth Pass (unit Qa), and Devils Postpile (units Qob, Qab, Qpb); interspersed with them were eruptions of more evolved lavas: (1) the dacites and low- $\mathrm{SiO}_{2}$ rhyolites of Mammoth Mountain (units Qqm, Qrm1, Qrm2) and two similar domes (unit Qqm) in the west moat, (2) several hybrid dacite dome flows (unit Qqm) in the northwest moat, and (3) 


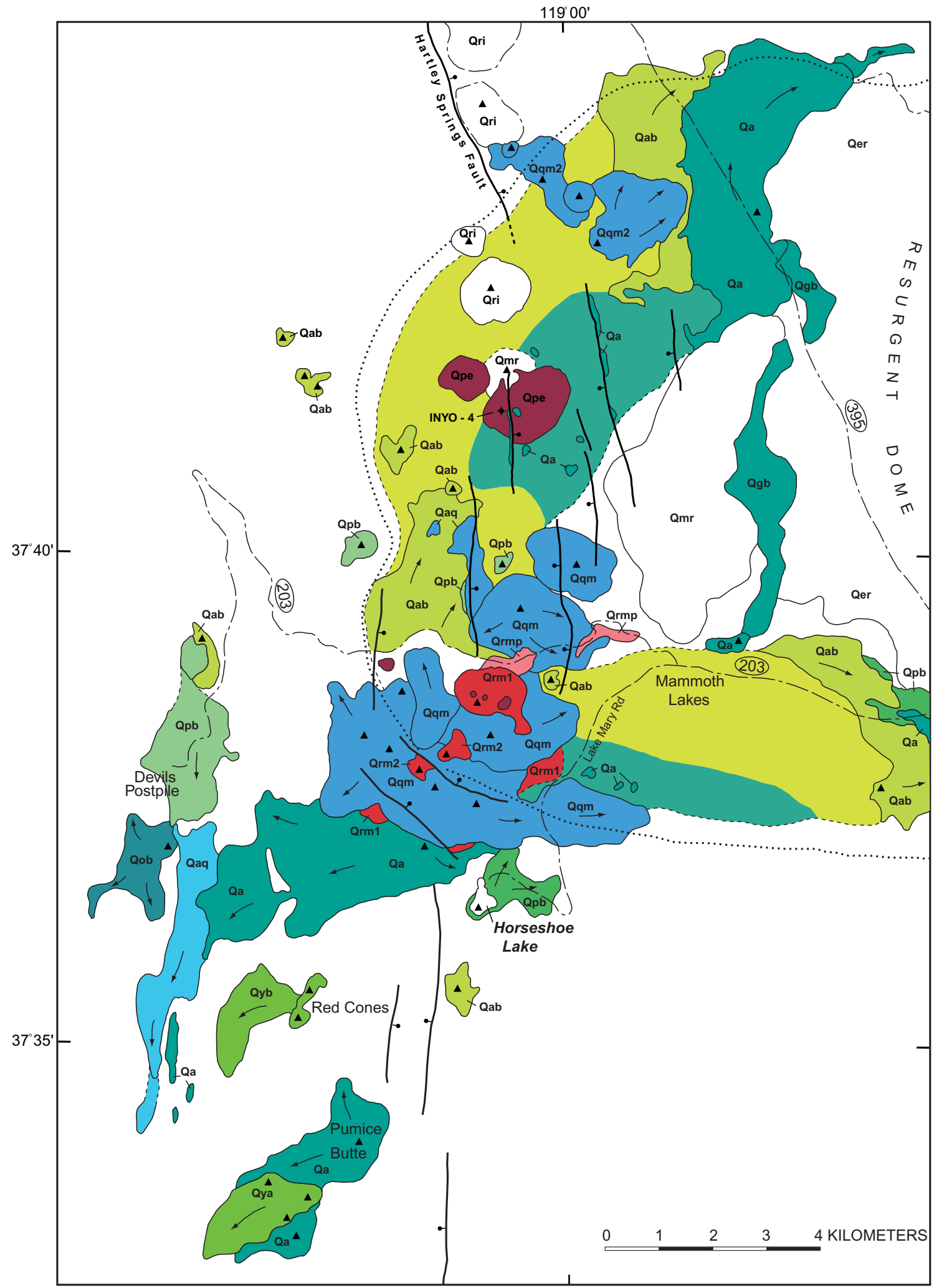

Figure 4. Sketch geologic map of west moat of Long Valley Caldera, Mammoth Mountain, and Devils Postpile area, Calif. (after Bailey, 1989). 
EXPLANATION (Figs. 4 - 6)

Dacite and low-silica rhyolite
Qd Dacite of Negit and Paoha Islands (6000 to <250 B.P.)
Qry Low-silica rhyolite of Paoha Island ( 250 B.P.)
Qri Low-silica rhyolite of Inyo Craters (600 B.P.)
Qr High-silica rhyolite of Mono Craters (30 ka - 600 B.P.)
Qqm2 Dacite of the northwest caldera moat $(<50$ ? ka)
Qpd Porphyritic dacite of Mono Craters and Paoha Island $(\sim 100$ ? ka)
Qrm2 Low-silica rhyolite of Mammoth summit and Lincoln Peak $(100 ?-50 \mathrm{ka})$
Qqm Dacite of Mammoth Mountain and Earthquake Domes
Qrm1 Basal low-silica rhyolite of Mammoth Mountain (255? - 100? ka)

\section{Basalt and trachyandesite}
Qyb Basalt of Red Cones (<10 ka)
Qyc Palagonitic basalt tephra of Black Point (13.3 ka)
Qya Younger trachyandesite of Pumice Butte (<100 - >25 ka, or possibly $<10 \mathrm{ka}$ )
Qa2 Basalt of June Lake secondary rootless cinder cone $(30-25 \mathrm{ka})$
Qa1 Basalt of June Lake main cinder cone (30 - $25 \mathrm{ka})$
Qab Sparsely phyric basalt of the caldera moat (100? - 64 ka)
Qgb Varient of Qab with olivine-plagioclase clusters
Qpb Coarsely phyric basalt of the caldera moat and Devils Postpile (280? - <100 or $>25 \mathrm{ka}$ )
Qa Trachyandesite of Mammoth Pass, Pumice Butte, and the caldera moat (155 - $90 \mathrm{ka})$
Qaq Sparsely phyric dacite of Devils Postpile and west caldera moat (undated)
Qob Olivine-augite basalt of the Buttresses; oldest flows in the Devils Postpile area, erupted through glacial ice of Tahoe or older age
Qmr Moat Rhyolite; locally contains mafic enclaves ( 500 ka)
Qer Early Rhyolite; locally contains mafic enclaves ( 650 ka)
Qhrd Hornblende-plagioclase phyric dacite, northeast caldera moat ( 700 ka)

Symbols:
- Volcanic vent
Normal fault; ball and bar on downthrown side
Direction of lava flowage from vent
Topographic outline of Long Valley Caldera floor

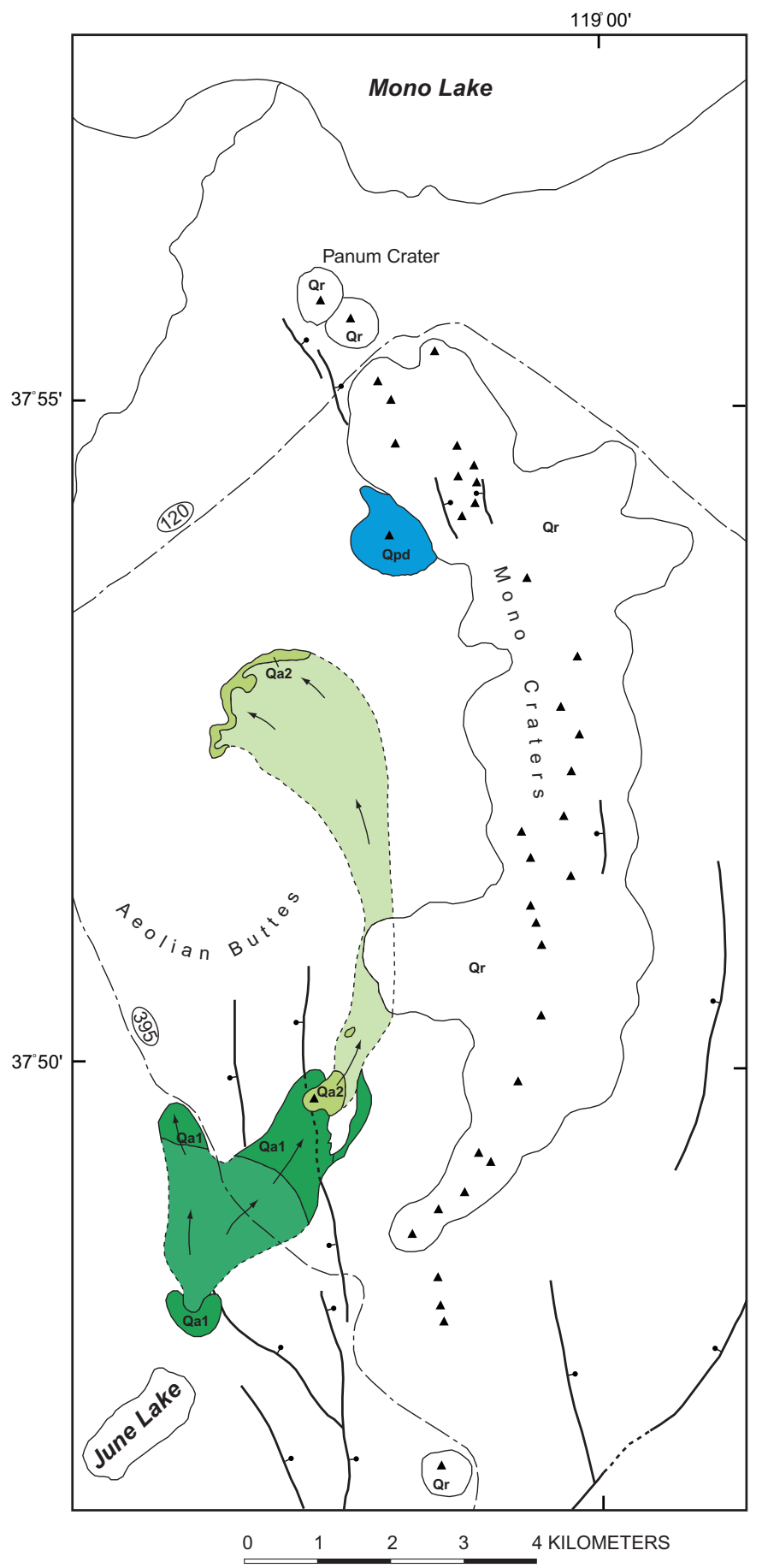

Figure 5. Sketch geologic map of June Lake-Mono Craters area, Calif. (after Bailey, 1989). 
two crystal-poor dacite flows (unit Qaq) in the west moat and at Devils Postpile. After about $30 \mathrm{ka}$, mafic eruptions migrated northward along the Mono-Inyo Craters fissure system to June Lake (unit Qa [25-30 ka], fig. 5), then to Black Point (unit Qyc [13 ka], fig. 6) on Mono Lake, and finally southward to Red Cones (unit Qyb [5 ka], fig. 4). These mafic eruptions were followed by dacite and low- $\mathrm{SiO}_{2}$ rhyolite eruptions at Mono Lake (units Qd [0.6-2 ka] and Qry [200 B.P.], fig. 6) and at Inyo Craters (unit Qri [600 B.P.], fig. 4) and were overlapped by high- $\mathrm{SiO}_{2}$ rhyolite eruptions at Mono Craters (units Qro [1-35 ka], Qry [600 B.P.], figs. 5, 6). The most recent $(\leq 5$ ka) eruptions along the Mono-Inyo Craters Volcanic Chain, of both basaltic and rhyolitic composition, have been confined to its northern and southern extremities, in and near Mono Lake and Inyo Craters and at Red Cones.
Because postcaldera Long Valley volcanism is particularly relevant to the current (post-1980) seismic unrest in the area and provides perspective on the type and characteristics of possible future eruptions, the postcaldera lavas are described in greater detail below.

\section{Caldera Suite}

Mafic to intermediate-composition lavas of the Caldera suite are localized mainly within the west half of Long Valley Caldera but also occur to the southwest outside the caldera to the vicinity of Devils Postpile. Their vents, except for the Early Rhyolite basalt enclaves, are aligned mainly along fissures parallel to the Mono-Inyo Craters Volcanic Chain and are clearly related to it. Thus, both the Caldera and Mono-Inyo

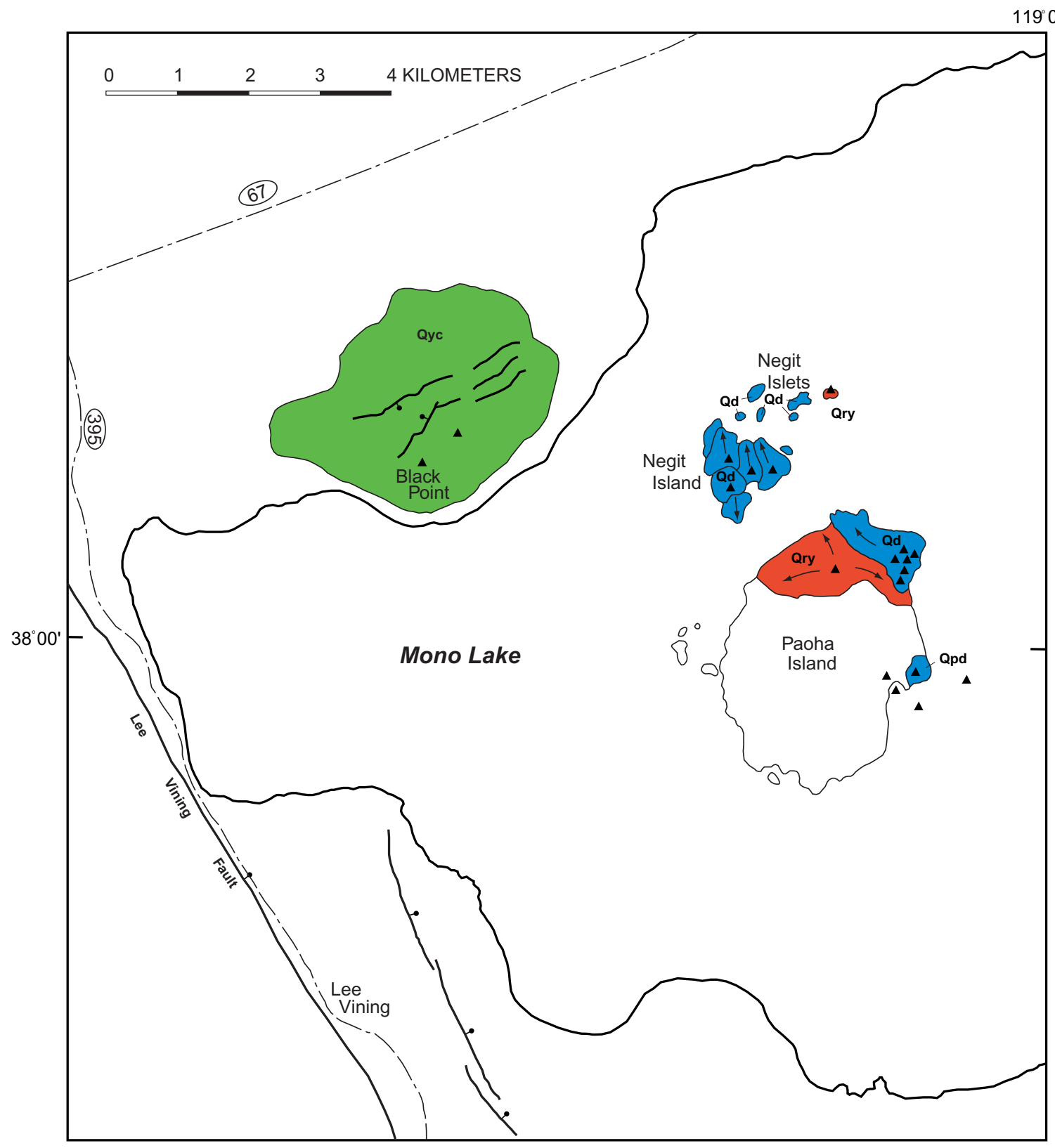

Figure 6. Sketch geologic map of Mono Lake area, Calif. (after Bailey, 1989). 
suites are here considered to be related to the Mono-Inyo Craters magmatic system.

\section{Basalt Enclaves}

The earliest postcaldera basalt occurs as mafic enclaves (magmatic inclusions) enclosed in a 680-ka Early Rhyolite dome (unit Qer, fig. 2) in the center of the resurgent dome and in a 500-ka Moat Rhyolite agglutinate ring and lava flow on the north flank of the resurgent dome (unit Qmr, fig. 2). The enclaves in the Early Rhyolite dome consist of vesiculated globular masses, as much as $10 \mathrm{~cm}$ in diameter, and slabs, as much as $50 \mathrm{~cm}$ across and $10 \mathrm{~cm}$ thick, showing thin, dark, chilled margins against the enclosing obsidian. The coarse vesicles at the outer margins of the enclaves are filled with finely vesicular white rhyolite pumice that merges with the enclosing obsidian, suggesting that both the basalt and obsidian were molten and vesiculating simultaneously - the dense rhyolite melt expanding to pumice as it oozed into the large vesicles forming at the enclave margins. The slablike enclaves apparently originated in the subsurface as vertical and horizontal sheets that intruded into and were marginally chilled by the molten host rhyolite, then were disrupted while their interiors were still molten, and finally were extruded with the rhyolite dome. The size distribution of the vesicles within these slabs suggests that they represent both vertical and horizontal sheets: in some slabs, vesicles formed symmetrically about a medial plane, as if the result of vertical flow, whereas in other slabs, vesicles are distributed asymmetrically, increasing in size and abundance from one side to the other, as if the result of gravitational control in a horizontal sheet. The extremely fine grain size and relatively high $\mathrm{MgO}$ content of the basalt indicates that it reacted little with its rhyolite host and probably was injected at relatively shallow depth only shortly before disruption and extrusion. The position of the enclave-rich Early Rhyolite dome at the center of the resurgent dome suggests that the basalt was fed into the rhyolitic-magma chamber from a subjacent central feeder, where the combination of injection pressure and buoyancy due to vesiculation quickly carried it to the chamber roof and facilitated its extrusion. The younger basalt enclaves in the 500-ka Moat Rhyolite (unit Qmr, fig. 2) on the north flank of the resurgent dome occur as 2- to 10-cm-diameter globular bombs in a pumiceous agglutinate ring and as denser globs in a flow issuing from it. Compositionally, these enclaves are more contaminated by their coarsely porphyritic (cooler) rhyolite host and probably were in contact with it longer than those in the aphyric (hotter) Early Rhyolite.

\section{Early Intracaldera Basalt-Trachyandesite Lavas}

The oldest and thickest complete section of postcaldera mafic lavas is a $319-\mathrm{m}$-thick sequence that was penetrated by slant corehole Inyo-4, drilled at the Inyo Craters (fig. 5) in the west moat of the caldera (Eichelberger and others, 1988). This flow sequence, described in detail by Vogel and others (1994), ranges in age from 151 to $415 \mathrm{ka}$ and comprises five distinct compositional and stratigraphic groups (I through $\mathrm{V}$, from top to bottom). Groups I through IV occur as a continuous sequence of superposed flows; group V, which occurs only as clasts in breccia dikes cutting Early Rhyolite at about $650-\mathrm{m}$ depth, $300 \mathrm{~m}$ below the base of the flow sequence, is believed to be derived by downward raveling in fissures from group $\mathrm{V}$ flows at the base of the flow sequence, which fortuitously were not intersected by the slant corehole (Vogel and others, 1994). Each group grades cyclically upward toward more evolved compositions from basalt to trachyandesite (50-58 weight percent $\mathrm{SiO}_{2}$ ). Significantly, this flow sequence is not interrupted by other intracaldera eruptive or sedimentary units, even though rhyolitic eruptions were occurring elsewhere in the caldera during this interval. Nor does the sequence enclose any of the glacial deposits believed to have formed during this interval. These relations suggest that the lavas were erupted over a much shorter interval than their K-Ar ages indicate (see discussion below).

\section{Late Intracaldera Basalt-Trachyandesite Lavas}

The intracaldera surface mafic flows sampled in this study (units Qpb, Qab, Qa, figs. 2, 4) form outcrops in the north, west, and south sectors of the caldera moat; their exposed thickness seldom exceeds a few tens of meters. Their relation to the corehole Inyo-4 flows is problematic. K-Ar ages on these surface flows in the south moat, as determined by Curry (1971), are $440 \mathrm{ka}$ for unit Qa and $192 \mathrm{ka}$ for unit Qab, whereas ages determined by Mankinen and others (1986) on these same flows are 129 and $64 \mathrm{ka}$, respectively. This discrepancy remains unresolved; however, their relation to overlying Tioga till (10-25 ka) and interbedded Casa Diablo till (now recognized as probably correlative with Older Tahoe till $[120-140 \mathrm{ka}])^{4}$ suggest that Mankinen and others' ages are likely correct.

\section{Extracaldera Basalt-Trachyandesite Lavas}

Basalts and trachyandesites similar in composition and age to the intracaldera lavas also were erupted outside the caldera at Mammoth Pass (unit Qa [86 ka], fig. 4), Pumice Butte (units Qa, Qya [<10?-200 ka]), and Devils Postpile (units

\footnotetext{
${ }^{4}$ This report closely follows the mapping and classical nomenclature of Sharp and Birman (1963) for the glacial moraines along the East Sierran escarpment, for example, Tioga, Tenaya, Tahoe, and Mono Basin, in order of increasing age. The ages of glaciations referred in this report are based on the cosmogenic ${ }^{26} \mathrm{Al}$ ages of Sierran glacial moraines determined by Phillips and others $(1990,1996)$ and on the analyses of Owens Lake sedimentary deposits in coreholes OL90-1 and OL90-2 by Benson and others (1996), Smith and others (1997), and Bischoff and others (1997). This research indicates approximate dates of 25-15 ka for the Tioga Glaciation, 32-30 ka or 60-50 ka for the Tenaya Glaciation, and 140-120 ka for the Tahoe Glaciation. The Mono Basin/Casa Diablo Glaciations have not been dated but possibly fall in the range 155-145 ka. These ages, however, are still a subject of debate and continuing research. In addition, some confusion has been introduced concerning the naming of moraines; for example, in Bloody Canyon, the moraines originally named and mapped as Tenaya and Tahoe are referred to as "Younger Tahoe" and “Older Tahoe," respectively, by recent workers.
} 
Qob, Qab, Qpb [100?-200? ka]). The trachyandesite flows at Mammoth Pass (Mammoth Pass flows, unit Qa [86 ka]), which were erupted at the south base of Mammoth Mountain from a crater now partly buried by dacite flows, poured both westward and eastward into San Joaquin Canyon and Horseshoe Lake basin, respectively. In Horseshoe Lake basin, Mammoth Pass trachyandesite flows are overlain by porphyritic basalts (Horseshoe Lake flows, unit Qpb, fig. 4), which were erupted from a subaerial vent within the present lakesite and poured eastward into Twin Lakes basin. This Horseshoe Lake vent has since been obliterated by Tioga glacial erosion; however, at very low lake levels, remnant oxidized spindle bombs and vent agglomerate are preserved at the shores. These Horseshoe Lake flows overlie Mammoth Pass trachyandesite and are littered with Tioga glacial erratics, indicating an age of 25-90 ka.

The trachyandesite flows in the vicinity of Pumice Butte (units Qa, Qya, fig. 4), which emerge from the base of two large cinder cones, have not been dated radiometrically. The older of these flows (unit Qa) are glaciated, most likely by Tahoe glaciers, but the younger flows (unit Qya) are not, suggesting that the younger flows postdate the Tioga Glaciation (25-10 ka); however, Tioga glaciers in San Joaquin Canyon may not have been thick enough to override these younger flows, and so, though younger than the Tahoe Glaciation (140-120 ka), they could predate the Tioga Glaciation.

At Devils Postpile, a sequence of lavas filling the bottom of San Joaquin Canyon includes, in stratigraphic succession, (1) the Buttresses porphyritic basalt flows (unit Qob, fig. 4), (2) the Rainbow Falls dacite flow (unit Qaq), (3) the Mammoth Pass trachyandesite flows (unit Qa), and (4) the Devils Postpile porphyritic basalt flow (unit $\mathrm{Qbp}$ ) and its probable cindery vent complex (unit Qab). The main mass of the Buttresses flows, which is perched on the west wall of San Joaquin Canyon, was fed by dikes that originate in a dike- and sill-laced palagonite complex on the canyon floor. A similar, smaller dike-fed mass occurs $2 \mathrm{~km}$ south on the east wall of the canyon. The flows (numbering at least three) have pillowed, palagonitic bases, indicating eruption into shallow water. These flows are inferred to have been erupted through a glacier and to have ponded in meltwater between the glacier margin and the canyon wall. Although the flows have not been dated radiometrically, topographic and intraglacial stratigraphic relations suggest that they postdate the Bishop Tuff. Though designated "Older basalt" (Bailey, 1989) because of their moderate degree of alteration, they are not necessarily the oldest flows in the postcaldera sequence. They clearly predate the Tioga Glaciation but could have been extruded through Tahoe or older glaciers, suggesting an age possibly as young as $120 \mathrm{ka}$. The Devils Postpile flow was erupted from a cinder-cone complex (unit Qab) north of the Postpile, flowed downcanyon, and ponded behind a Tahoe(?) recessional moraine (now mostly removed by erosion). Slow cooling of this ponded flow under subaerial conditions accounts for its spectacular, coarse columnar jointing. The flow was later overridden by Tioga glaciers, which grooved and polished its upper surface.

\section{Dacite Lavas}

On the northeast edge of the Long Valley Caldera floor at the southwest foot of Glass Mountain is a small, distinctive hornblende-plagioclase-phyric dacite dome (unit Qhrd, fig. 2). Its youthful morphology indicates that it was erupted on the caldera floor shortly after collapse, probably between 760 and $500 \mathrm{ka}$. Exceptionally well formed, small $(5-8 \mathrm{~cm})$-diameter columnar jointing on its lower flanks suggests that it was extruded into and chilled by Pleistocene Long Valley Lake water. This dome is petrographically and chemically similar to precaldera Basin and Range dacites on the north caldera rim; however, the dome is not a downfaulted precaldera remnant but appears to represent dacite lava from a vestigial precaldera Basin and Range magma source that leaked up along the caldera ring fracture shortly after caldera collapse. Though older and isolated from other Caldera and Mono-Inyo lavas, the dacite dome is included as a member of the postcaldera sequence (see table 1).

The more evolved dacitic lavas associated with intracaldera and extracaldera mafic lavas in the western part of the caldera include (1) Mammoth Mountain, a large domical dome-flow complex of coarsely porphyritic dacite (unit Qqm [60?-180 ka], fig. 4) and low-silica rhyolite (units Qrm1 [225 ka], Qrm2 [50 ka]); (2) two large dacite domes in the west moat (unit Qqm [142-148 ka]), petrographically similar to Mammoth Mountain; (3) a distinctive crystal-poor dacite flow (unit Qaq [103 ka]) in the west moat, similar to the Rainbow Falls dacite (unit Qaq) at Devils Postpile; and (4) a cluster of four hybrid porphyritic dacite domes and flows in the northwest moat (unit Qrm2 [<50? ka]).

On Mammoth Mountain, Koeppen (1983) recognized five eruptive sequences: (1) sparsely porphyritic biotite-augite rhyolite flows (unit Qrm1, fig. 4), exposed sporadically around the base of the mountain, and an associated locally thick pumice fall (unit Qrmp); (2-4) coarsely porphyritic hornblende-biotite and hypersthene-augite dacites (unit Qqm), forming the bulk of the edifice; and (5) porphyritic hornblende-biotite rhyolite (unit Qrm2), forming the summit dome. Noting the abundance of mafic inclusions in the dacites and the distribution of apparently coeval basalt vents within 4 to $5 \mathrm{~km}$ peripheral to the mountain, Koeppen suggested that the dacitic-magma chamber formed a shadow zone above a subjacent basalt sill complex.

\section{Mono-Inyo Suite}

Younger ( $<30 \mathrm{ka})$ Mono-Inyo lavas are limited to the axis of the Mono-Inyo Craters Volcanic Chain. Mono-Inyo vents are distributed sporadically along the axis between Black Point in the north and Red Cones in the south. As noted above, both the Caldera and Mono-Inyo suites are structurally related to the Mono-Inyo Craters fissure system but constitute only a part of the Mono-Inyo Craters Volcanic Chain. The distribution, age, and chemical and isotopic characteristics of the Caldera and Mono-Inyo suites differ sufficiently to justify distinguishing them. 


\section{Basalt Lavas}

June Lake.-At about $30 \mathrm{ka}$, trachyandesite eruptions (unit Qa1, fig. 5) formed a 90-m-high cinder cone northeast of June Lake. The cone was breached on its north side by a flow that broke out at its base and rafted away large segments of the cone, distributing them as scattered reddish-brown cindery hillocks on the flow surface. This flow bifurcated into two lobes to the north and northeast around the south end of Aeolian Buttes. At the toe of the northeastern lobe, a secondary, apparently rootless, cindery agglutinate vent formed; this vent was breached on its northeast side and fed lava from the main flow to a thinner, narrower secondary flow (unit Qa2), which coursed another $7 \mathrm{~km}$ northward down the valley between Aeolian Buttes and Mono Craters. Outflow from this secondary vent caused deflation of the main northeastern flow surface as lava drained from beneath its crust, thereby lowering its surface about $10 \mathrm{~m}$, forming a marginal "bathtub ring"-like lava ledge along the south side of Aeolian Buttes. The toe of this northeastern lobe and its associated rootless vent abut and bury the trace of a north-trending, west-facing fault scarp that displaces adjacent Tahoe and Tenaya(?) glacial moraines, suggesting that the position of the toe and rootless vent is related to ponding of the northeastern lobe against this scarp or, possibly, against the nearly coincident Tenaya(?) terminal moraine. The rootless vent agglutinate contains granitic blocks apparently derived from this moraine. The June Lake flow overlies Tahoe and Tenaya(?) terminal moraines and is partly overlapped by Tioga moraines. Bursik and Gillespie (1993), using a slightly different scenario, presented evidence suggesting that the June Lake eruptions occurred 30-25 ka.

Black Point.-Black Point, a flat-topped basaltic cinder cone on the north shore of Mono Lake (unit Qyc, fig. 6), is composed mainly of brown palagonitized scoriaceous ejecta that was erupted within Pleistocene Lake Russell (ancient Mono Lake) at $13.3 \mathrm{ka}$ (Lajoie, 1968), shortly after the lake's highest stand (2,155-m elevation), postdating the Tioga Glaciation (Benson and others, 1990). The initial Black Point eruptions were subaqueous, and interaction between the hot ejecta and lakewater caused pervasive palagonitization of the main cone. Its final eruptive pulse, however, occurred subaerially from a vent above lake level, because the youngest, black, cindery ejecta mantles the top and unconformably drapes the upper, terraced flanks of the brown, palagonitized cone, particularly on its west and southwest sides. These younger beds are composed of unaltered, poorly consolidated to unconsolidated, glassy, black basaltic cinder and ash, which, though probably also emplaced in lakewater, was sufficiently air cooled before immersion to prevent palagonitic alteration. The difference in emplacement temperature of the early brown palagonitized ejecta and the overlying black cinder and ash is indicated by the presence of botryoidal calcite fissure fillings (likely deposited by hydrothermal solutions) in the palagonitized beds and, in contrast, the presence of coarse "thinolite" crystal clusters and rosettes (Russell, 1886-87) in the vitric black ash and cinder. These thinolite crystals, now known to be pseudomorphs of ikaite $\left(\mathrm{CaCO}_{3} \cdot 6 \mathrm{H}_{2} \mathrm{O}\right.$; Shearman and Smith, 1985), form only at near-freezing temperatures (Bischoff and others, 1993a, b; Council and Bennett, 1993), indicating that the enclosing, air-cooled black cinder and ash was emplaced in very cold water. Apparently, enough time lapsed between eruption of the palagonitized beds and the unaltered black ash beds for the lake level to be lowered below the eruptive vent, which is on the south side of Black Point, $30 \mathrm{~m}$ below its flat summit. This lake-level change occurred over a sufficient duration to allow formation of at least two lake terraces below the summit terrace, indicating that the later eruption occurred long after the earlier eruptions, during the accelerated lakelevel decline due to rapid climate change after $13.3 \mathrm{ka}$ (see Benson and others, 1990, fig. 4).

Red Cones.-Red Cones (unit Qyb, fig. 4), about $5 \mathrm{~km}$ south-southwest of Mammoth Mountain and on the east rim of the Middle Fork San Joaquin Canyon, consists of twin 80-mhigh reddish-brown basalt cinder cones from which spilled a 2.5-km-long tongue of thin pahoehoe flows down the east wall of the canyon. These flows, which have not been glaciated and clearly postdate the Tioga Glaciation (28-15 ka), could be, on the basis of soil profiles, as young as $5 \mathrm{ka}$ (C.D. Miller, oral commun., 1978). Though erupted amidst older Caldera basalts, Red Cones, on the basis of age, chemistry, and isotopic data, belongs to the younger Inyo-Mono suite.

\section{Dacite Lavas}

The youngest postcaldera dacites occur at the north end of the Mono-Inyo Craters Volcanic Chain, mainly in Mono Lake. Negit Island (unit Qd, fig. 6), the largest dacitic mass, comprises a 100-m-high, black, agglutinated cinder cone and a flow emerging from its south base. The island also includes four rubbly-surfaced flows that abut the north and east sides of the cinder cone and were erupted from three vents aligned approximately east-west. Several small islets east of Negit Island constitute the top of another, mostly submerged dacitic flow. On the northeast end of Paoha Island is a cluster of young black dacite cinder cones and an associated 1-km-long dacite flow (unit Qd). The main mass of Paoha Island consists of white to buff tuffaceous lake-bottom sedimentary deposits that were uplifted by a shallow rhyolitic intrusion or cryptodome (unit Qry), the upper carapace of which protrudes as a sediment-littered mass of blocky obsidian on the north third of the island (Lajoie, 1968). A similar, smaller mass of rhyolitic lava that forms a small islet east of the Negit islets appears to be the source of numerous buoyant rhyolitic pumice blocks, many as large as $1 \mathrm{~m}$ in diameter, that floated to the lake surface and drifted to the north and west shores, where they have since become encrusted with carbonate deposits (Stine, 1987). Using ash stratigraphy and ${ }^{14} \mathrm{C}$ dating of tree trunks rooted on Mono Lake terraces and strandlines, Stine determined that Negit Island and the adjacent islets formed between 2,000 and 270 B.P., that Paoha Island rose above lake level after 265 B.P. (A.D. 1685), and that the Paoha dacite cones and flow were erupted after 227 B.P. (probably between A.D. 1723 and 
1855), shortly before arrival of the first exploratory expeditions scouting routes across the Sierra Nevada. An interesting historical note bearing on this eruption appears in the diary of Zenas Leonard, a member of Joseph Walker's 1834 expedition through the region (Smith, 1993, p. 198): Camping on the shore of what was evidently Mono Lake (although exact details of the expedition's route are uncertain), Leonard wrote, "There is also a great quantity of pumice stone floating on the surface of the water, and the shore is covered with them." That pumice blocks were still floating in the lake in 1834 suggests that the eruption probably occurred only a few years, or possibly a decade or two, earlier.

\section{Petrography and Chemistry}

\section{General Relations}

On total-alkalis/ $\mathrm{SiO}_{2}$-variation diagrams (fig. 7), both the precaldera and postcaldera sequences follow subparallel trends, evolving toward more silicic compositions over time, from basaltic though trachyandesitic to dacitic and rhyolitic. Although both sequences have alkali-lime indices (Peacock, 1931) of about 57, suggesting an apparent calc-alkalic trend, most of the mafic lavas have a distinctly alkalic affinity, as reflected by their position above the alkalic/subalkalic line in figure 7 and as implied by International Union of Geological Sciences (IUGS) nomenclature (Le Maitre, 1989). The lavas span the fields of basanite-tephrophonolite, basalt, trachybasalt, basaltic trachyandesite, trachyandesite, trachydacite, dacite, and rhyolite. On $\mathrm{K}_{2} \mathrm{O}-\mathrm{SiO}_{2}$ variation diagrams (not shown) most lavas fall in the high-K field, and some precaldera lavas would be considered absarokites and shoshonites. For simplicity in this report, however, the more general terms "basalt" (basalt, trachybasalt), "trachyandesite" (basaltic trachyandesite, trachyandesite), "dacite," "trachydacite," and "rhyolite" are used.

In spite of general similarities, significant mineralogic and chemical differences distinguish the precaldera and postcaldera sequences, as well as the chemical-geographic suites within them. Mineralogic differences, evident in hand samples during the early stages of mapping, are now attributable to

Figure 7. $\mathrm{K}_{2} \mathrm{O}+\mathrm{Na}_{2} \mathrm{O}$ versus $\mathrm{SiO}_{2}$ contents of precaldera and postcaldera basalt-dacite sequences. $A$, Central and East Sierran suites. Dashed line outline encloses the potassic Central Sierran suite; gray shading encloses the East Sierran suite. Note compositional gaps in the East Sierran suite. B, Basin and Range suite. Note compositional continuity of the Basin and Range suite relative to gaps in the East Sierran suite. $C$, Caldera suite. Note compositional gap between 59 and 64 weight percent $\mathrm{SiO}_{2}$. D, MonoInyo suite. Note compositional gap between 54 and 63 weight percent $\mathrm{SiO}_{2}$, occupied only by small-volume, mixed-composition mafic enclaves. International Union of Geological Sciences (IUGS) classification after Le Bas and others (1986).
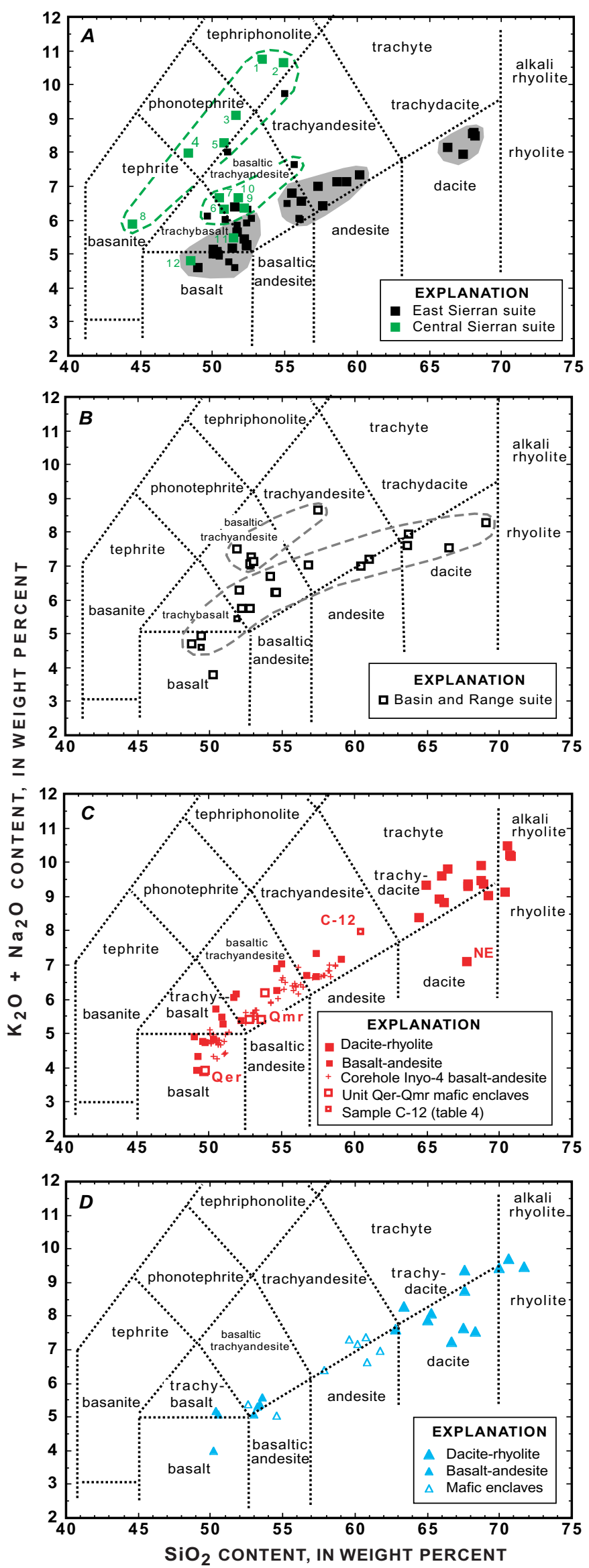
fundamentally different magmatic sources and processes. As discussed below, differences between the precaldera and postcaldera sequences are related to their derivation from different sources within the crust-mantle substructure, whereas differences within the sequences reflect fundamentally different magmatic processes operative in the Sierra Nevada and Basin and Range Provinces, that is, west and east, respectively, of the East Sierran frontal fault zone. In this report, the Long Valley precaldera and postcaldera sequences are subdivided informally into the following temporally and geographically, as well as chemically, defined suites (see table 1): the precaldera sequence (0.8- 4.0 Ma), comprising a Central Sierran suite, an East Sierran suite, and a Basin and Range suite; and the postcaldera sequence $(0-700 \mathrm{ka})$, comprising a Caldera suite (50- 700 ka) and a Mono-Inyo suite (0-30 ka).

Distinct mineralogic and chemical differences distinguish the lavas erupted east and west of the East Sierran frontal fault zone, defined locally by the Hilton Creek and Hartley Springs Faults (fig. 2), which trend northwest in left-stepping echelon fashion through the middle of the caldera. The precaldera Central Sierran and East Sierran suites include lavas erupted west of this fault zone, and the Basin and Range suite includes those erupted east of it. The transition between these three suites is gradational rather than abrupt; East Sierran lavas are intermediate in composition between Central Sierran and Basin and Range lavas. All three suites were coeval, spanning the interval 4.0-2.5 Ma. In the postcaldera sequence, basaltdacite lavas of the Caldera and Mono-Inyo suites constitute part of the Mono-Inyo Craters Volcanic Chain, which, as noted above, was erupted from the north-trending fissure system that extends from south of Mammoth Mountain, through the west moat of the caldera, to Mono Lake. The Caldera suite, limited to the southern part of the volcanic chain, includes 64-415-ka lavas erupted within the caldera (intracaldera), as well as some erupted outside the caldera (extracaldera) in the vicinity of Mammoth Mountain and Devils Postpile. The Mono-Inyo suite includes only the youngest $(0.2-30 \mathrm{ka})$ postcaldera lavas- those erupted mainly in the northern part of the chain - but also at least one of several cinder cones on the west wall of the caldera, as well as Red Cones, south of Mammoth Mountain. The petrographic and chemical characteristics of the precaldera and postcaldera sequences are described below, focusing first on the differences within the two sequences (that is, between the precaldera Central Sierran, East Sierran, and Basin and Range suites and between the postcaldera Caldera and Mono-Inyo suites) and then on the salient differences between the two sequences (see table 1).

\section{Petrography}

\section{Precaldera Sequence}

\section{Basalt}

The Central Sierran suite comprises the ultrapotassic lavas of the central Sierra Nevada studied by Van Kooten
(1980, 1981), who described them as ultrapotassic basanites, potassic olivine basalts, and alkali olivine basalts, which correspond in the IUGS classification of figure 7 to basanite-tephrophonolite, basalt, trachybasalt, and basaltic trachyandesite. All the lavas are olivine-diopside phyric; the more potassic lavas also contain phenocrysts of sanidine, plagioclase, and phlogopite \pm leucite; matrices consist of olivine, diopside, plagioclase, apatite, magnetite, and pseudobrookite \pm sanidine \pm phlogopite \pm leucite (Van Kooten, 1980).

East Sierran and Basin and Range basalts, mainly alkali olivine basalts, are, despite their chemical differences, mineralogically and texturally similar. In both suites, the basalts are predominantly olivine-augite phyric, although a few lavas contain subordinate plagioclase phenocrysts. Pyroxenes are less calcic than in the Central Sierran suite. Ferromagnesian phenocrysts, commonly as large as $3 \mathrm{~mm}$ in diameter, constitute 5 to 10 volume percent of the rock; rare picritic basalts contain as much as 20 volume percent olivine; and in the less common plagioclase-bearing basalts, total phenocrysts make up as much as 40 volume percent. The more mafic flows are nepheline normative (tables 2, 3). Olivine and augite phenocrysts are subhedral to euhedral; olivine is altered commonly to iddingsite and less commonly to chloritic minerals. Plagioclase phenocrysts are euhedral, weakly zoned, and finely albite twinned. Matrices typically consist of plagioclase, alkali feldspar, olivine, augite, Fe-Ti oxides, apatite, and, commonly, phlogopite, which also occurs as a vapor-phase mineral in vesicles; matrices range widely in texture from finely pilotaxitic to coarsely trachytic.

Various mantle and deep-crustal mafic xenoliths occur in some Central Sierran basalts (Van Kooten, 1980; Van Kooten and others, 1985; Ducea and Saleeby, 1996). Some East Sierran flows contain upper-crustal granitoid xenoliths, as well as partially resorbed xenocrysts of plagioclase and quartz, many of which are volcanic rather than plutonic in origin: relatively clear and lacking microscopic inclusions and fractures common in xenocrysts derived from the local Mesozoic granitoid basement, they appear to be phenocrysts derived by mixing with coeval dacitic magma.

\section{Trachyandesite}

Unlike the basalts, East Sierran and Basin and Range trachyandesites are distinct in mineralogy and texture. East Sierran trachyandesites are olivine-augite or olivine-augite-plagioclase phyric; the more silicic variants also contain hypersthene and (or) biotite phenocrysts. Most are relatively crystal poor (1-10 volume percent), but plagioclase- and biotite-bearing flows contain as much as 20 volume percent phenocrysts. Matrices consist of plagioclase, augite, apatite, and Fe-Ti oxides \pm hypersthene \pm biotite \pm sanidine. Olivine shows the same alteration as in the basalts. Phenocrysts are generally euhedral, but in some flows olivine and augite are partially resorbed. Basin and Range trachyandesites, in contrast, are typically hornblende-plagioclase phyric, although olivine-augite and olivine-augite-plagioclase phyric variants occur locally. Horn- 
Table 2. Chemical analyses of lavas of the East Sierran suite.

[Major-element-oxide contents in weight percent; minor-element contents in parts per million. $\mathrm{Mg} \#$, magnesium number, $\mathrm{Mg} /(\mathrm{Mg}+\mathrm{Fe}) ; \mathrm{SiO}_{2} *$, $\mathrm{SiO}{ }_{2}$ content recalculated to 100 -percent volatile free; n.a., not analyzed]

\begin{tabular}{|c|c|c|c|c|c|c|c|c|c|c|c|c|c|c|c|c|c|c|c|}
\hline 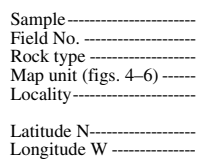 & 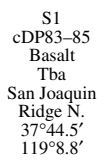 & 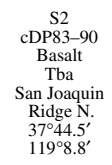 & $\begin{array}{c}\text { S3 } \\
\text { DP27-7 } \\
\text { Basalt } \\
\text { Tha } \\
\text { Deaddman } \\
\text { Pass } \\
377^{\circ} 04.5^{\prime} \\
119^{\circ} 39^{\prime}\end{array}$ & $\begin{array}{c}\text { S4 } \\
\text { cDP83-100 } \\
\text { Basalt } \\
\text { Tha } \\
\text { Tan Jaaunin } \\
\text { Ridge N, } \\
37444.1^{\prime} \\
119^{\circ} 8.1^{\prime}\end{array}$ & 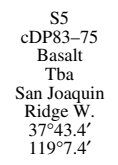 & $\begin{array}{c}\text { S6 } \\
\text { cD883-74 } \\
\text { Basalt } \\
\text { Tbat } \\
\text { San Joaquin } \\
\text { Ridge W. } \\
37^{\circ} 43.44^{\prime} \\
119^{\prime} 74^{\prime}\end{array}$ & 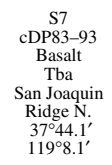 & $\begin{array}{c}\text { S8 } \\
\text { D-801e } \\
\text { Andesite } \\
\text { Tha } \\
\text { Agnew } \\
\text { Meadow } \\
3740 \text {. } \\
110^{\circ} .7^{\prime}\end{array}$ & $\begin{array}{c}\text { S9 } \\
\text { DP72-10 } \\
\text { Andesite } \\
\text { Tba } \\
\text { Deaddman } \\
\text { Pass } \\
37^{\circ}+40.6^{\prime} \\
119^{\circ} 3.9\end{array}$ & 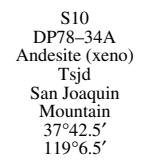 & $\begin{array}{c}\text { S11 } \\
\text { MC86-1 } \\
\text { Andesite } \\
\text { Tba } \\
\text { Hartley Springs } \\
\text { Fault } \\
-- \\
--\end{array}$ & $\begin{array}{c}\text { S12 } \\
\text { DP81-20 } \\
\text { Andesite } \\
\text { Qag } \\
\text { Pumice } \\
\text { Butte } 935.2 \\
373454 .^{\prime} \\
119^{\circ} 3.8^{\prime}\end{array}$ & $\begin{array}{c}\text { S13 } \\
\text { M72-19 } \\
\text { Andesite } \\
\text { Tha } \\
\text { Northwest } \\
\text { wall } \\
37^{4} 4.48^{\prime} \\
118^{\circ} 59.9^{\prime}\end{array}$ & 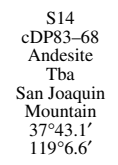 & 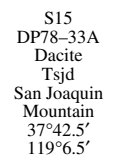 & $\begin{array}{l}\text { S16 } \\
\text { DP7-35-35 } \\
\text { Dacite } \\
\text { Tside } \\
\text { San Joaquin } \\
\text { Ridge } \\
37^{2} 42.2^{\prime} \\
119^{\circ} 5.8^{\prime}\end{array}$ & $\begin{array}{c}\text { S17 } \\
\text { DP78-19 } \\
\text { Dacite } \\
\text { Thjd } \\
\text { White Wing } \\
37^{\circ} 43.5^{\prime} \\
119^{\circ} 2.9^{\prime}\end{array}$ & $\begin{array}{c}\text { S18 } \\
\text { D-800 } \\
\text { Dacite } \\
\text { Tsid } \\
\text { Two Teats } \\
37^{\circ} 42.7^{\prime} \\
119^{\circ} 60^{\prime}\end{array}$ & 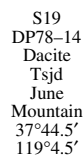 \\
\hline \multicolumn{20}{|c|}{ Major-element oxides } \\
\hline $\mathrm{SiO}_{2} *$ & 50.05 & 50.07 & 51.51 & 51.69 & 52.17 & 52.34 & 52.35 & 55.45 & 56.17 & 57.28 & 57.61 & 58.59 & 59.26 & 60.17 & 66.24 & 67.32 & 68.00 & 68.11 & 68.13 \\
\hline & 49.40 & 48.90 & 49.60 & 49.60 & 50.60 & 50.40 & 50.30 & 53.00 & 52.60 & 55.80 & 57.10 & 57.70 & 58.79 & 59.00 & 64.60 & 65.30 & 66.20 & 67.50 & 66.60 \\
\hline & 1.30 & 1.31 & 1.22 & 1.24 & 1.07 & .94 & .94 & .94 & .82 & .85 & .73 & .59 & .86 & 73 & .49 & .45 & .46 & .34 & 0.00 \\
\hline $\begin{array}{ll}\mathrm{Al}_{2} \mathrm{O}_{3} \\
\mathrm{~F}\end{array}$ & $\begin{array}{r}15.60 \\
260\end{array}$ & $\begin{array}{r}15.60 \\
359\end{array}$ & $\begin{array}{l}15.30 \\
253\end{array}$ & $\begin{array}{r}16.10 \\
297\end{array}$ & $\begin{array}{r}14.40 \\
3.71\end{array}$ & $\begin{array}{r}14.90 \\
3.29\end{array}$ & $\begin{array}{r}15.20 \\
3.43\end{array}$ & $\begin{array}{r}15.70 \\
260\end{array}$ & $\begin{array}{l}15.20 \\
1.87\end{array}$ & 19.30 & $\begin{array}{l}16.20 \\
270\end{array}$ & $\begin{array}{l}16.80 \\
273\end{array}$ & $\begin{array}{r}17.21 \\
224\end{array}$ & $\begin{array}{l}16.10 \\
268\end{array}$ & $\begin{array}{l}16.80 \\
248\end{array}$ & 16.60 & 16.00 & 16.40 & $\begin{array}{r}16.40 \\
222\end{array}$ \\
\hline $\begin{array}{l}\mathrm{l}_{\mathrm{e}} \mathrm{O}_{3}-\ldots \\
\mathrm{FeO}-\end{array}$ & $\begin{array}{l}2.60 \\
5.55\end{array}$ & $\begin{array}{l}3.99 \\
4.44\end{array}$ & $\begin{array}{l}2.53 \\
4.80\end{array}$ & $\begin{array}{l}2.97 \\
4.38\end{array}$ & $\begin{array}{l}3.71 \\
3.73\end{array}$ & $\begin{array}{l}3.29 \\
3.79\end{array}$ & $\begin{array}{l}3.43 \\
3.65\end{array}$ & $\begin{array}{l}2.60 \\
3.80\end{array}$ & $\begin{array}{l}1.87 \\
4.20\end{array}$ & $\begin{array}{l}4.13 \\
1.80\end{array}$ & $\begin{array}{l}2.70 \\
331\end{array}$ & $\begin{array}{l}2.73 \\
2.22\end{array}$ & $\begin{array}{l}2.24 \\
3.34\end{array}$ & $\begin{array}{l}2.68 \\
239\end{array}$ & $\begin{array}{r}2.48 \\
68\end{array}$ & $\begin{array}{l}1.65 \\
1.30\end{array}$ & $\begin{array}{l}1.53 \\
1.10\end{array}$ & $\begin{array}{l}1.10 \\
1.30\end{array}$ & 2.22 \\
\hline $\mathrm{MnO}-$ & $\begin{array}{r}5.53 \\
.14\end{array}$ & $\begin{array}{l}4.44 \\
.13\end{array}$ & $\begin{array}{l}4.80 \\
.13\end{array}$ & $\begin{array}{l}4.38 \\
.11\end{array}$ & $\begin{array}{r}3.73 \\
.11\end{array}$ & $\begin{array}{l}3.19 \\
.11\end{array}$ & $\begin{array}{l}3.63 \\
.11\end{array}$ & $\begin{array}{r}3.80 \\
.14\end{array}$ & $\begin{array}{r}4.20 \\
.12\end{array}$ & $\begin{array}{l}1.80 \\
.08\end{array}$ & $\begin{array}{r}3.11 \\
.10\end{array}$ & $\begin{array}{r}2.22 \\
.10\end{array}$ & $\begin{array}{r}3.34 \\
.09\end{array}$ & $\begin{array}{r}.399 \\
.08\end{array}$ & .08 & $\begin{array}{l}.300 \\
.07\end{array}$ & $\begin{array}{l}1.100 \\
.06\end{array}$ & $\begin{array}{r}1.30 \\
.09\end{array}$ & .06 \\
\hline $\mathrm{MgO}-$ & 10.00 & 9.67 & 8.11 & 8.33 & 10.20 & 9.96 & 9.59 & 5.00 & 5.36 & 2.51 & 5.85 & 5.29 & 3.82 & 4.26 & 1.10 & .94 & .87 & .76 & .65 \\
\hline $\mathrm{CaO}-$ & 8.46 & 8.58 & 7.91 & 7.34 & 7.43 & 7.40 & 7.30 & 7.40 & 6.95 & 5.60 & 6.42 & 5.73 & 5.32 & 5.17 & 3.06 & 2.74 & 2.59 & 2.70 & 2.67 \\
\hline $\begin{array}{l}\mathrm{Na}_{2} \mathrm{O}-\ldots \\
\mathrm{O}_{2} \mathrm{O}\end{array}$ & $\begin{array}{l}3.22 \\
1.86\end{array}$ & $\begin{array}{l}3.03 \\
1.85\end{array}$ & $\begin{array}{l}3.29 \\
2.87\end{array}$ & $\begin{array}{l}3.04 \\
2.38\end{array}$ & $\begin{array}{l}3.05 \\
2.24\end{array}$ & ${ }_{207}^{2.98}$ & $\begin{array}{l}2.98 \\
2.10\end{array}$ & $\begin{array}{l}3.80 \\
2.70\end{array}$ & $\begin{array}{l}3.54 \\
2.59\end{array}$ & $\begin{array}{l}3.86 \\
2.95\end{array}$ & $\begin{array}{l}3.96 \\
2.41\end{array}$ & $\begin{array}{l}4.50 \\
2.53\end{array}$ & $\begin{array}{l}4.06 \\
3.03\end{array}$ & $\begin{array}{l}4.02 \\
3.18\end{array}$ & $\begin{array}{l}4.02 \\
3.92\end{array}$ & $\begin{array}{l}3.79 \\
3.91\end{array}$ & $\begin{array}{l}4.10 \\
4.23 \\
-\end{array} \mathrm{V}$ & $\begin{array}{l}4.40 \\
4.10\end{array}$ & $\begin{array}{l}4.09 \\
4.19\end{array}$ \\
\hline 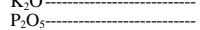 & $\begin{array}{l}1.80 \\
.57\end{array}$ & $\begin{array}{l}.889 \\
.57\end{array}$ & $\begin{array}{l}2.87 \\
.53\end{array}$ & $\begin{array}{r}.3 .88 \\
47\end{array}$ & $\frac{2.44}{45}$ & 2.07 & $\begin{array}{l}.100 \\
48\end{array}$ & 2.50 & $\begin{array}{r}2.39 \\
.39\end{array}$ & 2.53 & 2.41 & 293 & 3.03 & $\begin{array}{r}3.18 \\
44\end{array}$ & $\begin{array}{r}3.92 \\
30\end{array}$ & $\begin{array}{l}3.91 \\
.25\end{array}$ & $\begin{array}{l}4.23 \\
22\end{array}$ & $\begin{array}{l}4.10 \\
42\end{array}$ & $\begin{array}{l}4.19 \\
.20\end{array}$ \\
\hline $\mathrm{H}_{2} \mathrm{O}^{+}-\cdots$ & .65 & .84 & .77 & 1.32 & 1.29 & 1.48 & 1.60 & .92 & .29 & 1.60 & .15 & .19 & .29 & .34 & 1.60 & 2.30 & 1.80 & .77 & 1.30 \\
\hline $\mathrm{H}_{\mathrm{C}}^{2} \mathrm{O}-$ & .29 & .91 & .95 & $\begin{array}{l}1.25 \\
0.98\end{array}$ & 1.18 & 1.76 & 1.77 & n.a. & .26 & .46 & .11 & .17 & .04 & .59 & .38 & .21 & .35 & n.a. & .38 \\
\hline $\begin{array}{l}\mathrm{CO}_{2} \cdots \\
\mathrm{F} \cdots-\cdots\end{array}$ & $<.02$ & .20 & $\begin{array}{l}1.50 \\
07\end{array}$ & $\begin{array}{r}.98 \\
\text { na. }\end{array}$ & $\begin{array}{l}.19 \\
\text { na. }\end{array}$ & $\begin{array}{l}<.02 \\
\text { na. }\end{array}$ & .10 & $\begin{array}{l}2.80 \\
\text { na. }\end{array}$ & $\begin{array}{l}6.20 \\
06\end{array}$ & $\begin{array}{l}.01 \\
09\end{array}$ & $<.01$ & $<.01$ & .00 & .25 & .01 & .01 & .02 & .08 & .05 \\
\hline $\mathrm{Cl}---$ & $\begin{array}{l}\text { n.a. } \\
\text { n.a. }\end{array}$ & $\begin{array}{l}\text { hi.a. } \\
\text { n.a. }\end{array}$ & $<0.0035$ & $\begin{array}{l}\text { n.a. } \\
\text { n.a. }\end{array}$ & $\begin{array}{l}\text { hia. } \\
\text { n.a. }\end{array}$ & $\begin{array}{l}\text { n.a. } \\
\text { n.a. }\end{array}$ & $\begin{array}{l}\text { n.a. } \\
\text { n.a. }\end{array}$ & $\begin{array}{l}\text { n.a. } \\
\text { n.a. }\end{array}$ & .02 & .03 & $\begin{array}{l}\text { n.a. } \\
\text { n.a. }\end{array}$ & $\begin{array}{l}\text { n.a. } \\
\text { n.a. }\end{array}$ & $\begin{array}{l}\text { nia. } \\
\text { n.a. }\end{array}$ & $\begin{array}{l}\text { n.a. } \\
\text { n.a. }\end{array}$ & .02 & .03 & .31 & $\begin{array}{l}\text { n.a. } \\
\text { n.a. }\end{array}$ & .01 \\
\hline Total & 99.64 & 99.62 & 99.58 & 99.51 & 99.65 & 99.54 & 99.55 & 99.30 & 100.47 & 99.60 & 99.38 & 98.85 & 99.54 & 99.23 & 99.58 & 99.60 & 99.89 & 99.96 & 99.55 \\
\hline Mg\#-1- & 70 & 70 & 68 & 69 & 72 & 73 & 73 & 60 & 62 & 45 & 65 & 67 & 56 & 62 & 41 & 41 & 39 & 37 & 34 \\
\hline
\end{tabular}

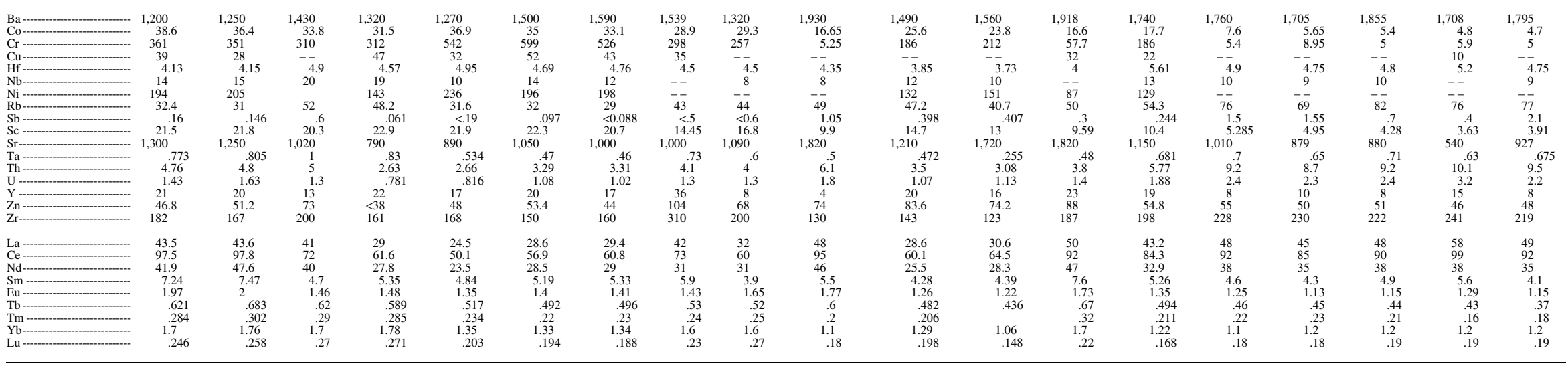


Table 3. Chemical analyses of lavas of the Basin and Range suite.

[Major-element-oxide contents in weight percent; minor-element contents in parts per million. $\mathrm{Mg \# \text {,magnesiumnumber, } \mathrm { Mg } / ( \mathrm { Mg } + \mathrm { Fe } ) ; \mathrm { SiO } _ { 2 } { } ^ { * } , \mathrm { SiO }} \mathrm{O}_{2}$ content recalculated to $100-$ percent volatile free; n.a., not analyzed]

\begin{tabular}{|c|c|c|c|c|c|c|c|c|c|c|c|c|c|c|c|c|c|c|c|}
\hline 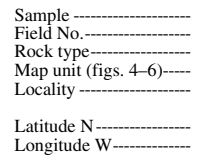 & $\begin{array}{c}\text { B1 } \\
\text { GMM78-1 } \\
\text { Basalt } \\
\text { Tba } \\
\text { Kelty } \\
\text { Meadow } \\
37^{\circ}+460^{\prime} \\
118^{\circ} 39.8^{\prime}\end{array}$ & $\begin{array}{c}\text { B2 } \\
\text { CTr2-3 } \\
\text { Basalt } \\
\text { Trba } \\
\text { Crestview 3 } \\
370^{\circ} 45.7^{\prime} \\
118^{\circ} 59.5^{\prime}\end{array}$ & $\begin{array}{c}\text { B3 } \\
\text { CD73-8 } \\
\text { Basalt } \\
\text { Tha } \\
\text { East wall } \\
37^{\circ} 41.2^{\prime} \\
118^{\circ} 40.6^{\prime}\end{array}$ & $\begin{array}{c}\text { B4 } \\
\text { C885-7 } \\
\text { Basalt } \\
\text { Baba } \\
\text { Bald Mountain } \\
\text { Spring, } \\
377^{4} 47.7^{\prime} \\
118^{\circ} 52.3^{\prime}\end{array}$ & $\begin{array}{c}\text { B5 } \\
\text { CT72-1 } \\
\text { Basalt } \\
\text { Tha } \\
\text { Crestview 1 } \\
37^{\circ} 45.7^{\prime} \\
118^{\circ} 55^{\prime} 5^{\prime}\end{array}$ & $\begin{array}{l}\text { B6 } \\
\text { CD85-6A } \\
\text { Basalt } \\
\text { Tha } \\
\text { Owens } \\
\text { River } 6 \\
377^{\circ} 34 .^{\prime} \\
118^{\circ} 37.0^{\prime}\end{array}$ & $\begin{array}{c}\text { B7 } \\
\text { GMB5-4 } \\
\text { Basalt } \\
\text { Trab } \\
\text { Dry Fork } \\
37^{\circ} 47.5^{\prime} \\
118^{\circ} 40.6^{\prime}\end{array}$ & $\begin{array}{l}\text { B8 } \\
\text { CD85-5 } \\
\text { Basalt } \\
\text { Tha } \\
\text { Owens } \\
\text { River } 5 \\
377^{\circ} 42.9^{\prime} \\
118^{\circ} 25.8^{\prime}\end{array}$ & $\begin{array}{l}\text { B9 } \\
\text { Cr55-6 } \\
\text { Andesite } \\
\text { Tba } \\
\text { NE. Bald } \\
\text { Mountain } \\
37^{\circ}+48.4^{\prime}{ }^{\prime} \\
118^{\circ} 524^{4}\end{array}$ & $\begin{array}{l}\text { B10 } \\
\text { CT78-7 } \\
\text { Andesite } \\
\text { Tha } \\
\text { Cowtrack } \\
\text { Mountain } \\
37 \text { onf }^{\prime} 9^{\prime} \\
118^{\circ} 50.4^{\prime}\end{array}$ & $\begin{array}{c}\text { B11 } \\
\text { CT85-30 } \\
\text { Andesite } \\
\text { Tha } \\
\text { Clark } \\
\text { Canyon } \\
377^{\circ} 46.1^{\prime} \\
118^{\circ} 54.9^{\prime}\end{array}$ & $\begin{array}{l}\text { B12 } \\
\text { GMS5-3 } \\
\text { Andesite } \\
\text { Tha } \\
\text { Dry Fork } \\
37^{\circ} 48.6^{\prime} \\
118^{\circ} 41.2^{\prime}\end{array}$ & $\begin{array}{c}\text { B13 } \\
\text { C815-9-9 } \\
\text { Dacite } \\
\text { Thm } \\
\text { Bald Mountain, } \\
\text { NE. 8874, } \\
37^{\circ} 4774^{\prime} \\
118^{\circ} 51.8^{\prime}\end{array}$ & $\begin{array}{l}\text { B14 } \\
\text { C778-8 } \\
\text { Andesite } \\
\text { Tha } \\
\text { Cowtract } \\
\text { summit } \\
377^{\circ 58.9} \\
118^{\circ} 48.6^{\prime}\end{array}$ & $\begin{array}{c}\text { B15 } \\
\text { CT72-4 } \\
\text { Andesite } \\
\text { Thm } \\
\text { Bald Mountain, } \\
\text { S. summit } \\
370464^{\prime} \\
118^{\circ} 54.4^{\prime}\end{array}$ & $\begin{array}{l}\text { B16 } \\
\text { CT85-28 } \\
\text { Dacite } \\
\text { Talm } \\
\text { Bald Mountain, } \\
\text { E. Control } \\
37^{\circ} 4644^{\prime} \\
118^{\circ} 54^{\prime} 0^{\prime}\end{array}$ & $\begin{array}{c}\text { B17 } \\
\text { GM21-1 } \\
\text { Dacite } \\
\text { Thba } \\
\text { Dry Fork } \\
37^{\circ} 47.8^{\prime} \\
118^{\circ} 40.8^{\prime}\end{array}$ & $\begin{array}{l}\text { B18 } \\
\text { CT17-2 } \\
\text { Dacite } \\
\text { Thm } \\
\text { N. rim } \\
8325 \\
37045.6^{\prime} \\
118^{\circ} 58.4\end{array}$ & $\begin{array}{c}\text { B19 } \\
\text { CT172-5 } \\
\text { Dacite } \\
\text { almm } \\
\text { Bald Mountain, } \\
\text { N. summit, } \\
37047.2^{\prime} \\
118^{8} 54.0^{\prime}\end{array}$ \\
\hline \multicolumn{20}{|c|}{ Major-element oxides } \\
\hline $\mathrm{SiO}_{2} *$ & 49.35 & 50.20 & 51.90 & 52.05 & 54.20 & 52.77 & 52.78 & 53.02 & 54.19 & 54.48 & 54.61 & 56.80 & 57.45 & 60.45 & 60.96 & 63.61 & 63.68 & 66.55 & 69.08 \\
\hline 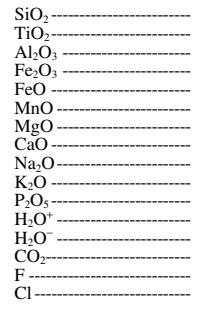 & $\begin{array}{r}48.60 \\
1.66 \\
14.10 \\
3.22 \\
6.20 \\
.15 \\
10.22 \\
8.67 \\
3.98 \\
.90 \\
.79 \\
1.10 \\
.18 \\
.01 \\
.11 \\
.02\end{array}$ & $\begin{array}{r}49.60 \\
.90 \\
15.70 \\
3.66 \\
6.50 \\
.17 \\
9.18 \\
9.09 \\
2.79 \\
.96 \\
.25 \\
.64 \\
.32 \\
.01 \\
.02 \\
.00\end{array}$ & $\begin{array}{r}51.40 \\
1.42 \\
15.40 \\
1.63 \\
6.00 \\
.13 \\
6.93 \\
7.91 \\
3.90 \\
3.53 \\
.78 \\
.42 \\
.15 \\
.01 \\
.13 \\
.01\end{array}$ & $\begin{array}{r}51.30 \\
1.32 \\
14.90 \\
3.75 \\
4.39 \\
.13 \\
8.13 \\
7.69 \\
3.00 \\
3.19 \\
.76 \\
.29 \\
.16 \\
.01 \\
\text { n.a. } \\
\text { n.a. }\end{array}$ & $\begin{array}{r}53.70 \\
1.03 \\
16.20 \\
2.27 \\
5.00 \\
.13 \\
7.32 \\
7.39 \\
3.77 \\
1.93 \\
.34 \\
.17 \\
.10 \\
.02 \\
.04 \\
.01\end{array}$ & $\begin{array}{r}51.40 \\
1.40 \\
15.00 \\
4.80 \\
3.31 \\
.12 \\
6.60 \\
6.85 \\
2.73 \\
4.17 \\
1.02 \\
.44 \\
.70 \\
.01 \\
\text { n.a. } \\
\text { n.a. }\end{array}$ & $\begin{array}{r}52.20 \\
1.32 \\
17.20 \\
5.05 \\
2.88 \\
.13 \\
5.20 \\
8.70 \\
3.65 \\
2.04 \\
.53 \\
.22 \\
.19 \\
\text { n.a. } \\
\text { n.a. }\end{array}$ & $\begin{array}{r}52.40 \\
1.42 \\
15.20 \\
4.13 \\
3.92 \\
.13 \\
6.48 \\
7.08 \\
2.87 \\
4.19 \\
1.02 \\
.13 \\
.12 \\
.01 \\
\text { n.a. } \\
\text { n.a. }\end{array}$ & $\begin{array}{r}53.70 \\
1.36 \\
17.40 \\
3.48 \\
3.95 \\
.12 \\
4.80 \\
7.11 \\
4.22 \\
2.42 \\
.56 \\
.12 \\
.28 \\
.01 \\
\text { n.a. } \\
\text { n.a. }\end{array}$ & $\begin{array}{r}53.00 \\
1.70 \\
16.40 \\
3.17 \\
4.60 \\
.12 \\
5.20 \\
6.44 \\
3.77 \\
2.29 \\
.59 \\
.77 \\
.01 \\
.30 \\
.18\end{array}$ & $\begin{array}{r}52.70 \\
.96 \\
15.40 \\
2.64 \\
4.20 \\
.11 \\
6.06 \\
7.95 \\
3.61 \\
2.40 \\
.48 \\
.37 \\
.35 \\
2.29 \\
\text { n.a. } \\
\text { n.a. }\end{array}$ & $\begin{array}{r}56.20 \\
.87 \\
16.30 \\
3.00 \\
3.54 \\
.11 \\
5.22 \\
6.25 \\
3.94 \\
3.03 \\
.48 \\
.20 \\
.16 \\
\text { n.a. } \\
\text { n.a. }\end{array}$ & $\begin{array}{r}56.20 \\
.97 \\
15.00 \\
5.52 \\
.09 \\
.08 \\
4.59 \\
6.09 \\
3.51 \\
4.96 \\
.82 \\
.16 \\
.08 \\
.01 \\
\text { n.a. } \\
\text { n.a. }\end{array}$ & $\begin{array}{r}59.10 \\
.89 \\
16.50 \\
3.03 \\
2.80 \\
.10 \\
3.04 \\
5.17 \\
3.22 \\
3.61 \\
.31 \\
1.20 \\
.34 \\
.01 \\
.07 \\
.04\end{array}$ & $\begin{array}{r}60.14 \\
.71 \\
17.30 \\
4.86 \\
.45 \\
.11 \\
2.32 \\
5.30 \\
4.19 \\
2.91 \\
.37 \\
.71 \\
.01 \\
.01 \\
\text { n.a. } \\
\text { n.a. }\end{array}$ & $\begin{array}{r}62.70 \\
1.61 \\
2.80 \\
2.93 \\
1.16 \\
1.05 \\
1.95 \\
4.60 \\
4.12 \\
3.38 \\
.27 \\
.18 \\
.27 \\
.01 \\
\text { n.a. } \\
\text { n.a. }\end{array}$ & $\begin{array}{r}62.90 \\
.75 \\
17.20 \\
1.54 \\
2.20 \\
2.06 \\
3.15 \\
3.86 \\
4.57 \\
3.27 \\
.27 \\
.15 \\
.01 \\
.04 \\
.02\end{array}$ & $\begin{array}{l}65.60 \\
.43 \\
16.80 \\
1.84 \\
1.00 \\
.06 \\
1.57 \\
3.67 \\
4.39 \\
3.03 \\
.18 \\
.44 \\
.21 \\
.02 \\
.06 \\
.01\end{array}$ & $\begin{array}{r}68.20 \\
.27 \\
16.50 \\
1.44 \\
.44 \\
.05 \\
1.03 \\
2.47 \\
4.93 \\
3.26 \\
.14 \\
.66 \\
.31 \\
.01 \\
.01 \\
.02\end{array}$ \\
\hline Total.- & 99.91 & 99.79 & 99.75 & 99.02 & 99.42 & 98.55 & 99.32 & 99.10 & 99.53 & 98.85 & 99.32 & 99.31 & 98.08 & 99.43 & 99.55 & 99.03 & 99.21 & 99.31 & 99.74 \\
\hline Mg\#--і- & 67 & 63 & 63 & 66 & 65 & 61 & 56 & 60 & 55 & 56 & 63 & 60 & 62 & 50 & 46 & 48 & 52 & 52 & 52 \\
\hline
\end{tabular}

Minor elements

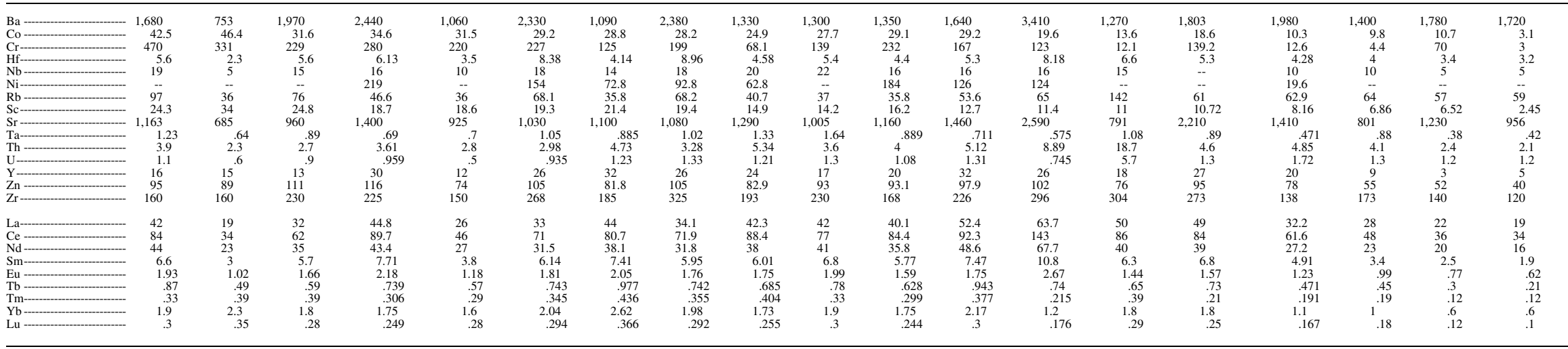


blende-plagioclase phyric flows are generally crystal rich (20 volume percent), whereas the few olivine-augite-bearing flows are generally crystal poor (5-10 volume percent). Hornblende phenocrysts typically are larger and more abundant than plagioclase phenocrysts. Hornblende phenocrysts invariably are completely dehydrated to opaque granular intergrowths of Fe-Ti oxides, augite, and plagioclase but retain their diagnostic euhedral shape. Matrices typically consist of pilotaxitic to trachytic intergrowths of plagioclase, augite, apatite, and Fe-Ti oxides. Hypersthene and biotite are rare both as phenocrysts and matrix minerals, although one particularly alkalic flow northeast of Bald Mountain (sample B13, table 3) contains 25 volume percent phenocrysts, including as much as 10 volume percent biotite.

\section{Dacite}

East Sierran and Basin and Range dacites also differ markedly. East Sierran dacites (Central Sierran dacites do not occur) are predominantly biotite-hornblende-plagioclase phyric; hypersthene, augite, sanidine, and, rarely, quartz may also be present; and phenocryst contents range from 30 to 50 volume percent. In contrast, Basin and Range dacites typically lack biotite and are hornblende-plagioclase phyric; augite also is present sporadically; and phenocryst contents range from 10 to 15 volume percent. Plagioclase phenocrysts in both suites are euhedral and complexly twinned, with weakly zoned, partially resorbed (sieved) interiors rimmed by more continuous, thin, oscillatory zoning. Hornblende phenocrysts in the two suites differ significantly: in Basin and Range dacites (as in the trachyandesites) hornblende invariably is altered to an opaque mixture of Fe-Ti oxides, augite, and plagioclase, whereas in Sierran dacites, hornblende, as well as biotite, is relatively unaltered - both only slightly reddened by oxidation. Sierran dacites possibly formed at shallower depths than Basin and Range dacites, so that their hornblende phenocrysts underwent less severe decompression and dehydration upon eruption. Mafic enclaves, consisting mainly of relatively coarse grained intergrown hornblende and plagioclase (and rare garnet), are common in East Sierran dacites but absent to sparse in Basin and Range dacites.

\section{Postcaldera Sequence}

\section{Quenched-Basalt Enclaves}

The globular and slablike basalt enclaves in the intracaldera Early and Moat rhyolites are nearly aphyric, containing only tiny $(\leq 0.3 \mathrm{~mm}$ diam $)$ microphenocrysts of olivine and augite set in a matrix of feathery, radiating, or sheathlike intergrowths of acicular plagioclase and green pyroxene. The enclaves generally are more coarsely vesicular at their margins than at their centers, whereas the matrices are microvesicular throughout, with polygonal interstices lined with Fe-Ti oxide-dusted brown glass. Most enclaves have conspicuously darker, finer grained margins than interiors. They resemble the mafic enclaves observed in the Inyo and Mono rhyolite domes (Varga and others, 1990; Kelleher and Cameron, 1990), which, though texturally similar, are trachyandesitic as a result of greater mixing with their host rocks. They also closely resemble chilled the mafic enclaves in the Coso Range rhyolites described by Bacon and Metz (1984) and Bacon (1986). These postcaldera mafic enclaves differ significantly from those that commonly occur in precaldera dacites, which consist of coarse-grained intergrowths of hornblende and plagioclase, are seldom vesicular, lack chilled margins, and generally are more evolved chemically. The coarser grain size and lower vesicularity of the precaldera enclaves suggest incorporation at greater depth, and the absence of chill rinds and their more evolved compositions suggest less thermal contrast between enclave and host rocks and longer contact with the host rocks before extrusion.

\section{Basalt}

Except for the above-described mafic enclaves and the Buttresses and Horseshoe Lake flows (described below), postcaldera basalt-trachyandesite lavas in both the Caldera and Mono-Inyo suites are mineralogically and texturally similar and do not warrant separate description. They are conspicuously plagioclase phyric, with subordinate olivine and augite phenocrysts. Even among the most crystal poor lavas, plagioclase is the dominant mineral phase and clearly was present on the liquidus during initial crystallization. These postcaldera basalts are of two distinct petrographic types, finely (sparsely) porphyritic and coarsely porphyritic; however, they do not differ significantly in chemical composition, suggesting that the coarsely porphyritic type, which is more prevalent, is simply a more completely crystallized variant of the finely porphyritic type, in turn implying that the more porphyritic basalts resided and cooled in the subsurface for longer periods before eruption.

Sparsely porphyritic basalts (units Qgb, Qab, fig. 4; corehole Inyo-4 groups I-III) are typically plagioclase-olivine phyric and contain less than 1 volume percent phenocrysts; plagioclase phenocrysts are euhedral, 2 to $6 \mathrm{~mm}$ long, and weakly zoned; olivine phenocrysts are smaller than $0.5 \mathrm{~mm}$ in diameter. Some of these flows (unit Qgb) contain sparse glomerocrysts of plagioclase $(\leq 1 \mathrm{~cm}$ diam) and olivine $(\leq 0.5$ $\mathrm{cm}$ diam), similar in composition to solitary phenocrysts. Coarsely porphyritic basalts (unit Qpb; corehole Inyo-4 groups IV, V) are typically plagioclase-olivine \pm augite phyric and contain 15 to 30 volume percent phenocrysts; the plagioclase phenocrysts are elongate laths or blocky crystals varying in size (max $5 \mathrm{~mm}$ diam). The larger plagioclase phenocrysts have weakly zoned, strongly sieved interiors, with partially resorbed rounded outlines surrounded by continuous, thinner, more strongly zoned rims. Olivine and augite phenocrysts are subhedral to euhedral and rarely exceed $1.5 \mathrm{~mm}$ in diameter. Matrices are typically a felty mesh of small plagioclase laths with interstitial olivine, augite, and $\mathrm{Fe}$-Ti oxide granules and have a pilotaxitic to intergranular texture. 
The Buttresses (unit Qob, fig. 4) and Horseshoe Lake (unit Qpb) basalts are coarsely olivine-augite phyric and mineralogically, texturally, and chemically resemble precaldera alkali-olivine basalts. As noted above, however, they postdate the Bishop Tuff and also are not necessarily the oldest postcaldera flows.

\section{Trachyandesite}

Postcaldera trachyandesites, the greatest volume of which occur in the west moat (unit Qa, fig. 4; corehole Inyo-4 groups I-III) and at Mammoth Pass (unit Qa) and Pumice Butte (units Qa, Qya), are petrographically akin to the abovedescribed sparsely porphyritic basalts in that they are plagioclase-olivine phyric, containing phenocrysts that range from 0.5 to $1.5 \mathrm{~mm}$ in diameter and constitute less than 1 volume percent of the rock.

\section{Dacite-Rhyolite}

Postcaldera dacites are petrographically the most diverse group of lavas in the entire volcanic field. They range in texture from nearly aphyric to coarsely porphyritic and contain widely varying phenocryst assemblages; their textures reflect crystallization conditions ranging from near equilibrium to extreme disequilibrium. Such diversity, together with their relatively small volumes and scattered distribution, suggest that they formed as small, discrete magma batches in scattered chambers, probably at various depths. Intimately associated with them on Mammoth Mountain and at Mono Lake are smaller volumes of low- $\mathrm{SiO}_{2}$ (70 weight percent $\mathrm{SiO}_{2}$ ) rhyolite.

The oldest postcaldera dacite (unit Qhrd, fig. 2), an isolated lava dome on the northeast floor of the caldera at the base of Glass Mountain, is distinctly unlike and unrelated to dacites of the Mono-Inyo Craters Volcanic Chain. The lava contains small plagioclase and hornblende phenocrysts set in a microcrystalline to glassy matrix and petrographically and chemically resembles typical precaldera Basin and Range dacite. However, its matrix texture, together with its unusually small diameter columnar jointing-consequences of extrusion into and chilling by Pleistocene Long Valley Lake-indicates a postcaldera eruptive age, in spite of its precaldera mineralogic and chemical affinities.

Mammoth Mountain lavas, as well as two large domes in the west moat (Earthquake Domes), consist predominantly of coarsely porphyritic hornblende-biotite dacite (unit Qqm, fig. 4), with varying hypersthene, augite, accessory apatite, and Fe-Ti oxide contents. Plagioclase, the dominant phenocryst, occurs as multiple-size populations in crystals ranging from 1 to $5 \mathrm{~mm}$ in diameter. The larger phenocrysts have broadly zoned, sieved cores and finely zoned continuous rims; the rims and smaller phenocrysts commonly have euhedral outlines. Total phenocryst contents range from 25 to 50 volume percent. The oldest Mammoth Mountain flows (unit Qrm1) are sparsely porphyritic plagioclase-biotite \pm augite rhyolite (70 weight percent $\mathrm{SiO}_{2}$ ); the youngest unit, the summit dome (unit Qrm2), also rhyolite (70.5 weight percent $\mathrm{SiO}_{2}$ ), is coarsely porphyritic, containing biotite, hornblende, plagioclase, and sparse sanidine phenocrysts, the sanidine commonly rimmed by plagioclase. This unit, as well as many of the intracaldera Moat and Inyo rhyolites, may be described as "rapakivi rhyolite," analogous to rapakivi granite.

The hybrid dacite domes and flows clustered in the northwest caldera moat (unit Qqm2, fig. 4) are distinctive in that they contain abundant phenocrysts derived from other magma types. Three of these four flows, in addition to containing typical dacite phenocrysts (hornblende-biotite-augite-hypersthene-plagioclase), also contain large, resorbed plagioclase, sanidine, and quartz phenocrysts from a rhyolitic source, as well as numerous small (1-5 cm diam), ovoid, reddish-brown mafic enclaves of basaltic-trachyandesitic composition. These particular units, the youngest (probably $<50 \mathrm{ka}$ ) of the intracaldera dacites, have apparently mixed and mingled with both basaltic and rhyolitic magmas and incorporated phenocrysts from rhyolitic magmas, either western Moat Rhyolite or Inyo Craters rhyolite. A fourth flow in this cluster, compositionally a 60-weight-percent- $\mathrm{SiO}_{2}$ trachyandesite (sample $\mathrm{C} 12$, table 4; described as "olivine quartz latite" by Rinehart and Ross, 1964, p. 56-60), contains, in addition to hornblende, biotite, and plagioclase phenocrysts, magnesian olivine, augite, and more calcic plagioclase crystals in varying degrees of resorption and reaction-apparently the result of thorough mixing of dacitic and basaltic magmas. Judging from the homogeneous distribution of incorporated basaltic phenocrysts and the homogeneity of the matrix, mingling in this flow, as well as in the other hybrid dacites, occurred within a subsurface chamber, well before extrusion.

The distinctive crystal-poor dacite variant in the west moat (unit Qaq, fig. 4) and at Devils Postpile (Rainbow Falls flow, unit Qaq) contains as much as 10 volume percent plagioclase, hypersthene, augite, and magnetite phenocrysts, 0.5 to $1.0 \mathrm{~mm}$ across, commonly in glomerophyric clusters. A few larger plagioclase phenocrysts have blocky to vermicular sieved cores, but most phenocrysts are euhedral and lack disequilibrium textures. The groundmass is typically brown glass crowded with crystallites.

Most Mono-Inyo dacites (unit Qd, fig. 6) are sparsely porphyritic to nearly aphyric, containing 1 to 5 volume percent euhedral plagioclase \pm hornblende \pm biotite \pm hypersthene \pm augite phenocrysts, 0.5 to $2.0 \mathrm{~mm}$ long, set in a matrix of brown glass containing varying amounts of plagioclase microlites and crystallites. In contrast, the isolated dacite dome (unit Qpd, fig. 5) at the north end of the Mono Craters rhyolite chain, partly buried by rhyolite flows, is coarsely porphyritic, with unusually large ( $>2 \mathrm{~cm}$ diam) plagioclase phenocrysts; it contains numerous mafic enclaves with exceptionally calcic $\left(\mathrm{An}_{90}\right)$ plagioclase phenocrysts.

\section{Summary}

Excluding the distinctive, highly potassic Central Sierran lavas, precaldera basalts of both the East Sierran and 
Table 4. Chemical analyses of lavas of the Caldera suite.

[Major-element-oxide contents in weight percent; minor-element contents in parts per million. Mg\#, magnesium number, $\mathrm{Mg} /(\mathrm{Mg}+\mathrm{Fe}) ; \mathrm{SiO}_{2} *$, $\mathrm{SiO}{ }_{2}$ content recalculated to 100 -percent volatile free; $\mathrm{LOI}$, loss on ignition at $925^{\circ} \mathrm{C}$; n.a., not analyzed]

\begin{tabular}{|c|c|c|c|c|c|c|c|c|c|c|c|c|c|c|c|c|c|}
\hline \multirow[b]{2}{*}{ 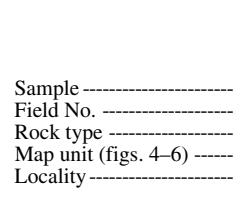 } & \multicolumn{2}{|c|}{ Mafic enclaves } & \multicolumn{15}{|c|}{ Intracaldera lavas } \\
\hline & $\begin{array}{c}\text { C1 } \\
\text { M92-1 } \\
\text { Basalt } \\
\text { Qer } \\
\text { Resurgent } \\
\text { dome }\end{array}$ & $\begin{array}{l}\text { C2 } \\
\text { M72-90 } \\
\text { Basalt } \\
\text { Qmr } \\
\text { North } \\
\text { flow }\end{array}$ & $\begin{array}{c}\text { C3 } \\
\text { M72-37 } \\
\text { Basalt } \\
\text { Qgb } \\
\text { NW. moat }\end{array}$ & $\begin{array}{c}\text { C4 } \\
\text { M72-7 } \\
\text { Basalt } \\
\text { Qab } \\
\text { S. moat 3 }\end{array}$ & $\begin{array}{c}\text { C5 } \\
\text { CT72-13 } \\
\text { Basalt } \\
\text { Qpb } \\
\text { N. moat }\end{array}$ & $\begin{array}{c}\text { C6 } \\
\text { DP73-1 } \\
\text { Basalt } \\
\text { Qpb } \\
\text { W. moat 1 }\end{array}$ & $\begin{array}{c}\text { C7 } \\
\text { M72-15 } \\
\text { Basalt } \\
\text { Qa } \\
\text { NW. moat }\end{array}$ & $\begin{array}{c}\text { C8 } \\
\text { DP73-12 } \\
\text { Basalt } \\
\text { Qab } \\
\text { W. moat 2 }\end{array}$ & $\begin{array}{c}\text { C9 } \\
\text { M72-99 } \\
\text { Basalt } \\
\text { Qpb } \\
\text { S. moat 2 }\end{array}$ & $\begin{array}{l}\text { C10 } \\
\text { M72-5 } \\
\text { Andesite } \\
\text { Qab } \\
\text { S. moat 1 }\end{array}$ & $\begin{array}{c}\text { C11 } \\
\text { DP72-13 } \\
\text { Andesite } \\
\text { Qa } \\
\text { Inyo Ctr L. }\end{array}$ & $\begin{array}{c}\text { C12 } \\
\text { M73-5 } \\
\text { Andesite } \\
\text { Qqm } \\
\text { NW. moat }\end{array}$ & $\begin{array}{c}\text { C13 } \\
\text { DP72-1A } \\
\text { Dacite } \\
\text { Qqm } \\
\text { NW. wall }\end{array}$ & $\begin{array}{c}\text { C14 } \\
\text { M73-4 } \\
\text { Dacite } \\
\text { Qqm } \\
\text { Earthquake } \\
\text { dome }\end{array}$ & $\begin{array}{l}\text { C15 } \\
\text { DP73-3 } \\
\text { Dacite } \\
\text { Qqa } \\
\text { NW. moat }\end{array}$ & $\begin{array}{c}\text { C16 } \\
\text { M72-92 } \\
\text { Dacite } \\
\text { Qqm } \\
\text { Earthquake } \\
\text { flow }\end{array}$ & $\begin{array}{l}\text { C17 } \\
\text { CT72-14 } \\
\text { Dacite } \\
\text { Qhrd } \\
\text { NE. moat }\end{array}$ \\
\hline $\begin{array}{l}\text { Latitude N- } \\
\text { Longitude W - }\end{array}$ & $\begin{array}{l}37^{\circ} 00.6^{\prime} \\
118^{\circ} 53.4^{\prime}\end{array}$ & $\begin{array}{l}37^{\circ} 04.44^{\prime} \\
118^{\circ} 53.5^{\prime}\end{array}$ & $\begin{array}{l}37^{\circ} 42.5^{\prime} \\
118^{\circ} 56.9^{\prime}\end{array}$ & $\begin{array}{l}37^{\circ} 38.7^{\prime} \\
118^{\circ} 55.9^{\prime}\end{array}$ & $\begin{array}{l}37^{\circ} 45.2^{\prime} \\
118^{\circ} 53.9^{\prime}\end{array}$ & $\begin{array}{l}37^{\circ} 39.9^{\prime} \\
119^{\circ} 1.3^{\prime}\end{array}$ & $\begin{array}{l}37^{\circ} 43.5^{\prime} \\
118^{\circ} 57.7^{\prime}\end{array}$ & $\begin{array}{l}37^{\circ} 40.7^{\prime} \\
119^{\circ} 0.5^{\prime}\end{array}$ & $\begin{array}{l}37^{\circ} 38.3^{\prime} \\
118^{\circ} 53.9^{\prime}\end{array}$ & $\begin{array}{l}37^{\circ} 39.5^{\prime} \\
118^{\circ} 55.6^{\prime}\end{array}$ & $\begin{array}{l}37^{\circ} 41.5^{\prime} \\
119^{\circ} 0.6^{\prime}\end{array}$ & $\begin{array}{l}37^{\circ} 40.1^{\prime} \\
119^{\circ} 1.4^{\prime}\end{array}$ & $\begin{array}{l}37^{\circ} 44.2^{\prime} \\
119^{\circ} 0.5^{\prime}\end{array}$ & $\begin{array}{l}37^{\circ} 40.0^{\prime} \\
118^{\circ} 59.5^{\prime}\end{array}$ & $\begin{array}{l}37^{\circ} 39.9^{\prime} \\
19^{\circ} 1.3^{\prime}\end{array}$ & $\begin{array}{l}377^{\circ} 39.3^{\prime} \\
119^{\circ} 0.0^{\prime}\end{array}$ & $\begin{array}{r}37^{\circ} 45.2^{\prime} \\
118^{\circ} 47.0^{\prime}\end{array}$ \\
\hline
\end{tabular}

\begin{tabular}{|c|c|c|c|c|c|c|c|c|c|c|c|c|c|c|c|c|c|}
\hline \multicolumn{18}{|c|}{ Major-element oxides } \\
\hline $\mathrm{SiO}_{2} *$ & 49.17 & 53.57 & 48.99 & 50.48 & 50.83 & 50.92 & 51.73 & 51.86 & 52.19 & 54.66 & 56.72 & 60.41 & 65.99 & 66.41 & 67.81 & 68.71 & 67.74 \\
\hline $\mathrm{SiO}_{2} \ldots$ & 48.80 & 52.03 & 48.19 & 50.25 & 50.69 & 50.74 & 51.63 & 51.65 & 51.99 & 54.25 & 56.25 & 59.88 & 64.95 & 66.10 & 67.38 & 68.72 & 66.47 \\
\hline $\mathrm{TiO}_{2}-\mathrm{O}^{-}$ & 1.69 & 1.30 & 1.94 & 1.94 & 1.54 & $\begin{array}{r}1.55 \\
1052\end{array}$ & 2.14 & 1.88 & 1.31 & 1.98 & 1.54 & 1.04 & .56 & .66 & .69 & .56 & .45 \\
\hline $\begin{array}{l}\mathrm{Al}_{2} \mathrm{O}_{3} \\
\mathrm{Fe} \mathrm{O}_{2}\end{array}$ & $\begin{array}{r}16.90 \\
424\end{array}$ & 18.34 & $\begin{array}{l}17.50 \\
1099\end{array}$ & $\begin{array}{r}17.67 \\
3.13\end{array}$ & 18.52 & $\begin{array}{r}18.53 \\
3.19\end{array}$ & $\begin{array}{r}17.45 \\
319\end{array}$ & 17.51 & 20.76 & 17.64 & 17.49 & 17.16 & 16.75 & 16.83 & 15.85 & 16.16 & 16.37 \\
\hline $\begin{array}{l}\mathrm{Fe}_{2} \mathrm{O}_{3} \\
\mathrm{FeO}-\end{array}$ & $\begin{array}{l}4.24 \\
4.84\end{array}$ & 7.28 & 9.99 & $\begin{array}{l}3.13 \\
6.81\end{array}$ & 1.43 & $\begin{array}{l}3.19 \\
505\end{array}$ & $\begin{array}{l}3.19 \\
6.88\end{array}$ & $\begin{array}{l}2.93 \\
614\end{array}$ & $\begin{array}{l}1.65 \\
510\end{array}$ & 3.53 & 2.49 & $\begin{array}{l}1.35 \\
414\end{array}$ & $\begin{array}{l}1.42 \\
1.91\end{array}$ & 3.06 & .94 & 1.25 & 1.34 \\
\hline $\mathrm{MnO}-$ & $\begin{array}{r}4.84 \\
.14\end{array}$ & n.a. & n.a. & 6.81 & $\begin{array}{r}7.00 \\
.14\end{array}$ & $\begin{array}{r}5.05 \\
.13\end{array}$ & $\begin{array}{r}6.88 \\
.15\end{array}$ & $\begin{array}{l}6.14 \\
.15\end{array}$ & $\begin{array}{r}5.19 \\
.10\end{array}$ & $\begin{array}{r}5.23 \\
.14\end{array}$ & 5.41 & $\begin{array}{r}4.14 \\
.10\end{array}$ & $\begin{array}{l}1.91 \\
.07\end{array}$ & .00 & $\begin{array}{r}2.28 \\
.09\end{array}$ & $\begin{array}{l}1.20 \\
.09\end{array}$ & $\begin{array}{l}1.55 \\
.05\end{array}$ \\
\hline MgO-- & 7.11 & 4.64 & 6.37 & 5.07 & 5.56 & 5.55 & 4.16 & 4.70 & 4.34 & 2.97 & 2.85 & 2.69 & .80 & .83 & .74 & .09 & 1.18 \\
\hline $\mathrm{CaO}$ & 11.30 & 8.47 & 8.98 & 8.33 & 8.80 & 9.11 & 7.54 & 7.79 & 8.61 & 6.12 & 5.96 & 4.60 & 2.34 & 2.02 & 1.94 & 1.38 & 3.61 \\
\hline $\mathrm{Na}_{2} \mathrm{O}$ & 3.02 & 3.51 & 3.62 & 4.02 & 3.83 & 3.71 & 4.18 & 4.10 & 3.78 & 4.65 & 4.39 & 4.29 & 4.42 & 5.51 & 5.08 & 5.36 & 4.10 \\
\hline $\mathrm{K}_{2} \mathrm{O}$----- & .88 & 1.75 & $\begin{array}{r}1.20 \\
50\end{array}$ & 1.65 & 1.64 & 1.54 & 1.87 & 2.02 & 1.57 & 2.21 & 2.26 & 3.61 & 5.04 & 4.23 & 4.21 & 4.53 & 2.87 \\
\hline $\begin{array}{l}\mathrm{P}_{2} \mathrm{O}_{5}-\ldots- \\
\mathrm{H}_{2} \mathrm{O}^{+}----------\end{array}$ & .32 & $\begin{array}{c}.42 \\
1 . \mathrm{OOI}\end{array}$ & $\begin{array}{c}.59 \\
-29 \text { (LOI) }\end{array}$ & $\begin{array}{r}.53 \\
22\end{array}$ & .58 & .54 & .61 & .72 & .32 & .53 & .42 & .27 & .16 & .19 & .16 & .09 & .13 \\
\hline 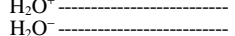 & .3 & $1.24(\mathrm{LOI})$ & $-.29(\mathrm{LOI})$ & .22 & .01 & .15 & .01 &. .13 & .29 & .34 & .46 & .45 & 1.03 & .06 & .15 & .54 & 1.31 \\
\hline $\begin{array}{l}\mathrm{H}_{2} \mathrm{O}_{2}^{-} \\
\mathrm{O}_{2}\end{array}$ & $\begin{array}{r}.29 \\
<0.01\end{array}$ & $\begin{array}{l}-- \\
\text { n.a. }\end{array}$ & $\begin{array}{l}-- \\
\text { n.a. }\end{array}$ & $\begin{array}{l}.06 \\
.01\end{array}$ & $\begin{array}{l}.02 \\
\text { n.a. }\end{array}$ & $\begin{array}{l}.03 \\
.01\end{array}$ & $\begin{array}{l}.01 \\
.01\end{array}$ & $\begin{array}{l}0 \\
\text { n.a. }\end{array}$ & $\begin{array}{l}.04 \\
\text { n.a. }\end{array}$ & $0^{.1}$ & $\begin{array}{l}.07 \\
.01\end{array}$ & $\begin{array}{l}.05 \\
.01\end{array}$ & $\begin{array}{l}.07 \\
.01\end{array}$ & $\begin{array}{l}0 \\
\text { n.a. }\end{array}$ & $\begin{array}{l}.06 \\
.02\end{array}$ & $\begin{array}{l}.14 \\
.01\end{array}$ & $\begin{array}{l}.04 \\
\text { n.a. }\end{array}$ \\
\hline 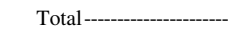 & 99.44 & 99.09 & 99.18 & 99.83 & 99.76 & 99.83 & 99.83 & 99.72 & 99.95 & 99.69 & 99.72 & 99.64 & 99.53 & 99.6 & 99.59 & 100.71 & 99.47 \\
\hline 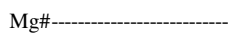 & 61 & 56 & 54 & 49 & 55 & 56 & 43 & 49 & 54 & 39 & 40 & 47 & 31 & 35 & 30 & 34 & 44 \\
\hline
\end{tabular}

Minor elements

\begin{tabular}{|c|c|c|c|c|c|c|c|c|c|c|c|c|c|c|c|c|c|}
\hline 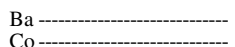 & 425 & 1,040 & 695 & 1,025 & 1,004 & 938 & 925 & 1,075 & 1,010 & 1,480 & 1,091 & 1,292 & 1,590 & 1,883 & 1,560 & 1,690 & 1,444 \\
\hline $\mathrm{Cr}$ & $215^{-}$ & 35 & $\begin{array}{l}41.9 \\
22.5\end{array}$ & $\begin{array}{l}34.8 \\
57.2\end{array}$ & $\begin{array}{l}27.3 \\
13.6\end{array}$ & $\begin{array}{l}30.7 \\
89\end{array}$ & 36.7 & 27.8 & $\begin{array}{r}27.5 \\
53.1\end{array}$ & 18 & 20.6 & 15.1 & 4.4 & 1.7 & 2.4 & 1.6 & 6.1 \\
\hline $\mathrm{Cu}$ - & 43 & -- & -- & 49 & 23 & 25 & 30 & 24 & $\begin{array}{l}35.1 \\
26\end{array}$ & 19 & 16 & $\begin{array}{l}44 \\
16\end{array}$ & 2 & $<2$ & $<2$ & $<1.2$ & $\begin{array}{c}10.9 \\
7\end{array}$ \\
\hline Ga - & -- & -- & -- & 26 & 24 & 28 & 27 & 26 & 30 & 21 & 26 & 27 & 21 & 26 & 27 & 20 & 22 \\
\hline Hf ----- & -- & 4.17 & 4.5 & 5.1 & 4.4 & 4.3 & 5 & 5.3 & 3.1 & -- & 4.4 & 6.8 & 8 & 9.2 & 7.5 & 9.1 & 3.6 \\
\hline 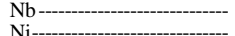 & 13 & 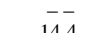 & 52 & 23 & -- & -- & 10 & 7 & -7 & -- & -- & -7 & 20 & -- & -- & 20 & -- \\
\hline 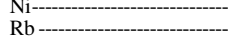 & 60 & $\begin{array}{l}14.4 \\
37.8\end{array}-10$ & 14 & 25 & 29 & 22 & 100 & 28 & 40 & $<10$ & -- & $\begin{array}{l}27 \\
83\end{array}$ & 90 & -- & & & -- \\
\hline 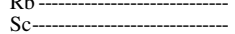 & 11 & 20.40 & 24.30 & 22.73 & 19.32 & 20.75 & 21.84 & 19.44 & 13.79 & 28 & 16.53 & 8389 & $\begin{array}{l}99 \\
52\end{array}$ & ${ }_{45}^{89}-54-2$ & 108 & 121 & 43 \\
\hline $\mathrm{Sr}$ & 660 & 1,190 & 1,080 & 1,120 & 1,920 & 1,200 & 1,820 & 820 & 890 & 1,160 & 1,200 & 480 & 430 & 410 & 330 & $180^{4.40}$ & 770 \\
\hline Ta & 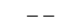 & .94 & 1.00 & 1.01 & .86 & & .9 & 1.09 & .67 & 1,100 & .82 & 1.13 & 1.1 & 1.58 & 1.35 & 1.63 & .31 \\
\hline 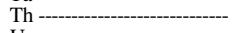 & -- & 2.7 & 2.7 & 4.4 & 2.9 & 3.9 & 2.8 & 4.7 & 2.2 & -- & 4.2 & 8.3 & 12.4 & 8.9 & 9.8 & 10.7 & 2.7 \\
\hline & -- & 1.66 & .6 & .9 & .09 & .8 & 2.1 & 1.3 & 26.3 & -- & 1.4 & 2.6 & 3 & 2.8 & 3.4 & 4 & .8 \\
\hline V- V-- & -- & -- & -- & 321 & 329 & 250 & 373 & 230 & 200 & 258 & 268 & 140 & 46 & $<15$ & 30 & 21 & 67 \\
\hline 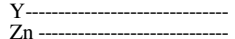 & $\begin{array}{l}18 \\
50\end{array}$ & $80^{--}$ & -- & 41 & 35 & 27 & 41 & 27 & 16 & 49 & 27 & 22 & 26 & 28 & 30 & 30 & $<20$ \\
\hline $\mathrm{Zn}$ & 178 & $\begin{array}{r}82 \\
200\end{array}$ & 202 & $\begin{array}{l}104 \\
213\end{array}$ & 270 & $\begin{array}{l}102 \\
305\end{array}$ & $\begin{array}{l}114 \\
320\end{array}$ & $\begin{array}{l}114 \\
327\end{array}$ & $\begin{array}{r}75 \\
405\end{array}$ & 257 & $\begin{array}{l}122 \\
273\end{array}$ & $\begin{array}{r}75 \\
369\end{array}$ & $\begin{array}{r}55 \\
377\end{array}$ & $\begin{array}{r}75 \\
481\end{array}$ & $\begin{array}{r}72 \\
409\end{array}$ & $\begin{array}{r}63 \\
393\end{array}$ & $\begin{array}{r}56 \\
169\end{array}$ \\
\hline La ---о- & 30 & 177 & 38 & 59 & 41 & 52 & 43 & 61 & 30 & -- & 40 & 52 & 73 & 63 & 54 & 60 & 20 \\
\hline $\mathrm{Ce}$--1-- & 49 & 75.2 & 79 & 106 & 80 & 96 & 81 & 108 & 56 & -- & 72 & 87 & 113 & 113 & 92 & 109 & 36 \\
\hline $\mathrm{Nd}$ - & -- & 97 & 41 & 56 & 43 & 48 & 46 & 58 & 32 & -- & 39 & 38 & 41 & 49 & 43 & 46 & 17 \\
\hline 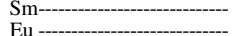 & -- & $\begin{array}{l}14.8 \\
2.28\end{array}$ & $\begin{array}{l}7.5 \\
2.25\end{array}$ & $\begin{array}{l}9.7 \\
2.39\end{array}$ & 8.3 & 8.4 & $\begin{array}{l}8.4 \\
2.19\end{array}$ & $\begin{array}{l}7.8 \\
2.32\end{array}$ & 5.1 & -- & $\begin{array}{l}6.8 \\
165\end{array}$ & $\begin{array}{l}6.7 \\
1.62\end{array}$ & $\begin{array}{l}6.3 \\
1.42\end{array}$ & $\begin{array}{l}8.1 \\
167\end{array}$ & $\begin{array}{l}7.1 \\
15\end{array}$ & $\begin{array}{l}7.5 \\
1.49\end{array}$ & 3.22 \\
\hline | & - & 12.3 & 6.4 & 9.8 & 7.9 & 7 & 7 & 7.2 & $\begin{array}{l}1.45 \\
5.1\end{array}$ & 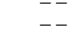 & $\begin{array}{l}1.03 \\
6.7\end{array}$ & $\begin{array}{l}1.02 \\
4.6\end{array}$ & $\begin{array}{l}1.42 \\
7.7\end{array}$ & $\begin{array}{l}1.07 \\
7.7\end{array}$ & 7.8 & $\begin{array}{l}1.49 \\
6.5\end{array}$ & 4.3 \\
\hline $\mathrm{Tb}$ & -- & 1.63 & .86 & 1.03 & .99 & .91 & 1.06 & .94 & .63 & -- & .75 & .72 & .65 & .89 & .78 & .8 & .37 \\
\hline Tm -- & -- & .72 & .42 & .28 & .20 & .28 & .30 & .35 & .19 & -- & .25 & .30 & .20 & .39 & .34 & .36 & .13 \\
\hline 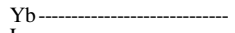 & -- & 4.52 & 2.5 & 2.5 & 2.6 & 2.2 & 2.5 & 2.6 & 1.4 & -- & 2.1 & 2.4 & 2 & 3.2 & 2.7 & 3 & .85 \\
\hline Lu & -- & .64 & .36 & .33 & .35 & .32 & .34 & .36 & .19 & -- & .28 & .35 & .32 & .45 & .39 & .43 & .14 \\
\hline
\end{tabular}

${ }^{1} \mathrm{Total}_{\mathrm{Fe}}$ as $\mathrm{Fe}_{2} \mathrm{O}_{3}$. 
Table 4. Chemical analyses of lavas of the Caldera suite-Continued

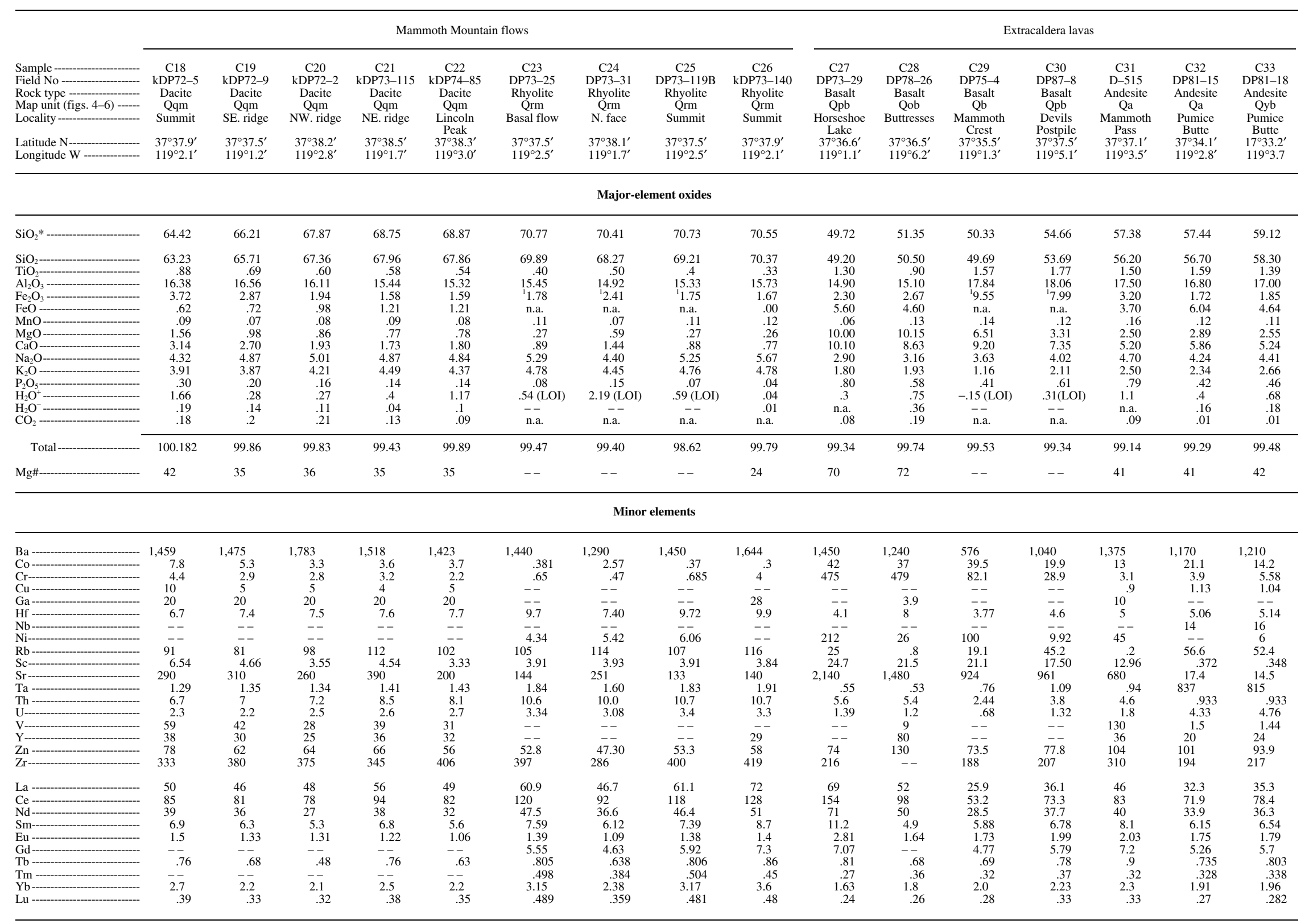


Basin and Range suites are typically olivine-augite phyric. East Sierran trachyandesites typically contain olivine, augite, hypersthene, and plagioclase phenocrysts, whereas Basin and Range trachyandesites are predominantly hornblendeplagioclase phyric. East Sierran dacites are hornblende-biotite-plagioclase \pm pyroxene phyric, whereas Basin and Range dacites, like their associated trachyandesites, are hornblendeplagioclase phyric, with hornblende thoroughly altered to opaque Fe-Ti oxides-pyroxene-plagioclase aggregates. East Sierran dacites commonly contain mafic enclaves, whereas Basin and Range dacite generally lack them.

In contrast, postcaldera basalts and trachyandesites of both the Caldera and Mono-Inyo suites are dominantly plagioclase-phyric, with lesser amounts of olivine and augite. Postcaldera dacites vary widely in composition, verging toward rhyolite (70 weight percent $\mathrm{SiO}_{2}$ ). Except for the older northeast-moat dacite, they petrographically resemble precaldera East Sierran dacites rather than Basin and Range dacites, typically are hornblende-biotite-plagioclase \pm pyroxene phyric, and commonly contain mafic enclaves and basaltic, as well as rhyolitic, xenocrysts.

\section{Major- and Trace-Element Chemistry}

\section{Previous Work}

Long Valley as a cohesive volcanic entity did not attract the attention of petrologists until 1968, when it was first recognized as a caldera with a central resurgent dome (Smith and Bailey, 1968). However, earlier work by Gilbert (1938, 1941) on the Bishop Tuff and Glass Mountain, and by Rinehart and Ross (1964) and Huber and Rinehart (1967) on the geology of the Mount Morrison and Devils Postpile quadrangles, contributed significantly toward recognition of the caldera, which, in turn, influenced the selection of Long Valley as a focus of the USGS' Geothermal Research Program in 1972 (Muffler and Williams, 1976). In addition to the seminal geochemical study of the Bishop Tuff by Hildreth (1979) and the USGS-supported work reported here and elsewhere (Bailey and others, 1976; Bailey, 1983, 1984), several additional petrologic and isotopic studies, partly stimulated by the current (post-1980) seismic unrest at Long Valley, have contributed to understanding the evolution of the volcanic field: the work of Metz and Mahood (1991) and Halliday and others (1989) on the Glass Mountain rhyolite complex, of Sampson and Cameron (1987) and Kelleher and Cameron (1990) on the Inyo Craters and Mono Craters rhyolites, respectively, of Cousens (1996) on the postcaldera basaltic lava sequence, and of Heuman and Davies (1997) on the intracaldera Early and Moat Rhyolites.

\section{Methods}

The rock samples described and the chemical analyses reported here were collected between 1972 and 1987 during mapping of the volcanic field (Bailey, 1989). The field numbers listed in tables 2 through 5 show the quadrangle and year in which the sample was collected, for example, M72-21: M=Mount Morrison quadrangle, 72=1972, 21=21 st sample collected that year. The analyses were performed in the USGS laboratories in Lakewood, Colo., Reston, Va., and Menlo Park, Calif. Whole-rock major-element analyses of rocks collected between 1972 and 1976 were performed by classical wetchemical methods at the Lakewood laboratory; major-element analyses of rocks collected after 1976 were performed by wavelength-dispersive X-ray-fluorescence spectroscopy, also at Lakewood. Trace-element analyses before 1976 were done by various methods, including quantitative photospectroscopy, atomic-absorption spectroscopy, and fluorometric analysis. After 1976, trace-element and rare-earth-element analyses were performed by energy-dispersive X-ray-fluorescence and neutron-activation analysis at Lakewood and Reston, respectively. The methods and precision and accuracy of USGS chemical analyses were evaluated by Taggart and others (1987) and Baedecker and McKown (1987). The few previously unpublished Sr-isotopic analyses of Long Valley lavas reported here, which were by R.W. Kistler (USGS, Menlo Park) and R.E. Chaudet (Virginia Polytechnic Institute), are listed in table 6, along with all other available published Sr-, $\mathrm{Nd}-$, and $\mathrm{Pb}$-isotopic analyses.

\section{Precaldera Sequence}

\section{General Relations}

On total-alkalis- and $\mathrm{K}_{2} \mathrm{O}-\mathrm{SiO}_{2}$-variation diagrams (figs. $7 A, 8 A$ ) and, to some degree, on $\mathrm{P}_{2} \mathrm{O}_{5^{-}}, \mathrm{Rb}-$, $\mathrm{Ba}-$, and $\mathrm{Zr}-\mathrm{SiO}_{2^{-}}$ variation diagrams (fig. $8 B$ ), the Central Sierran and East Sierran suites constitute three distinct subparallel trends with increasing $\mathrm{SiO}_{2}$ content, each at successively lower alkali contents: (1) Central Sierran basanite-tephrophonolite lavas, (2) Central Sierran basalt-trachyandesite lavas, and (3) East Sierran basalt-trachyandesite-dacite lavas. Compositional trends 1 and 2 comprise the ultrapotassic and potassic mafic lavas of Van Kooten (1980, 1981); trend 3 comprises the East Sierran basalts and associated more highly evolved trachyandesites and dacites. A small group of Basin and Range lavas, somewhat more potassic than average, also fall within trend 2. Significantly, the three Sierran compositional trends are distributed generally west to east across the Sierra Nevada crest, with alkalinity decreasing systematically eastward. In addition, a striking feature of East Sierran trend 3 is the conspicuous compositional gaps between basalts, trachyandesites, and dacites on major- and trace-element-variation diagrams (figs. 7A, 8). In contrast, the Basin and Range suite, though closely following the East Sierran trend, shows a more continuous range of compositions, with increasing $\mathrm{SiO}_{2}$ content. This difference between the East Sierran and Basin and Range suites does not appear to be the result of limited or selective sampling because analyses from two other complementary, though smaller, data sets (Moore and Dodge, 1980; Ormerod and others, 1988) show similar patterns and compositional gaps. 

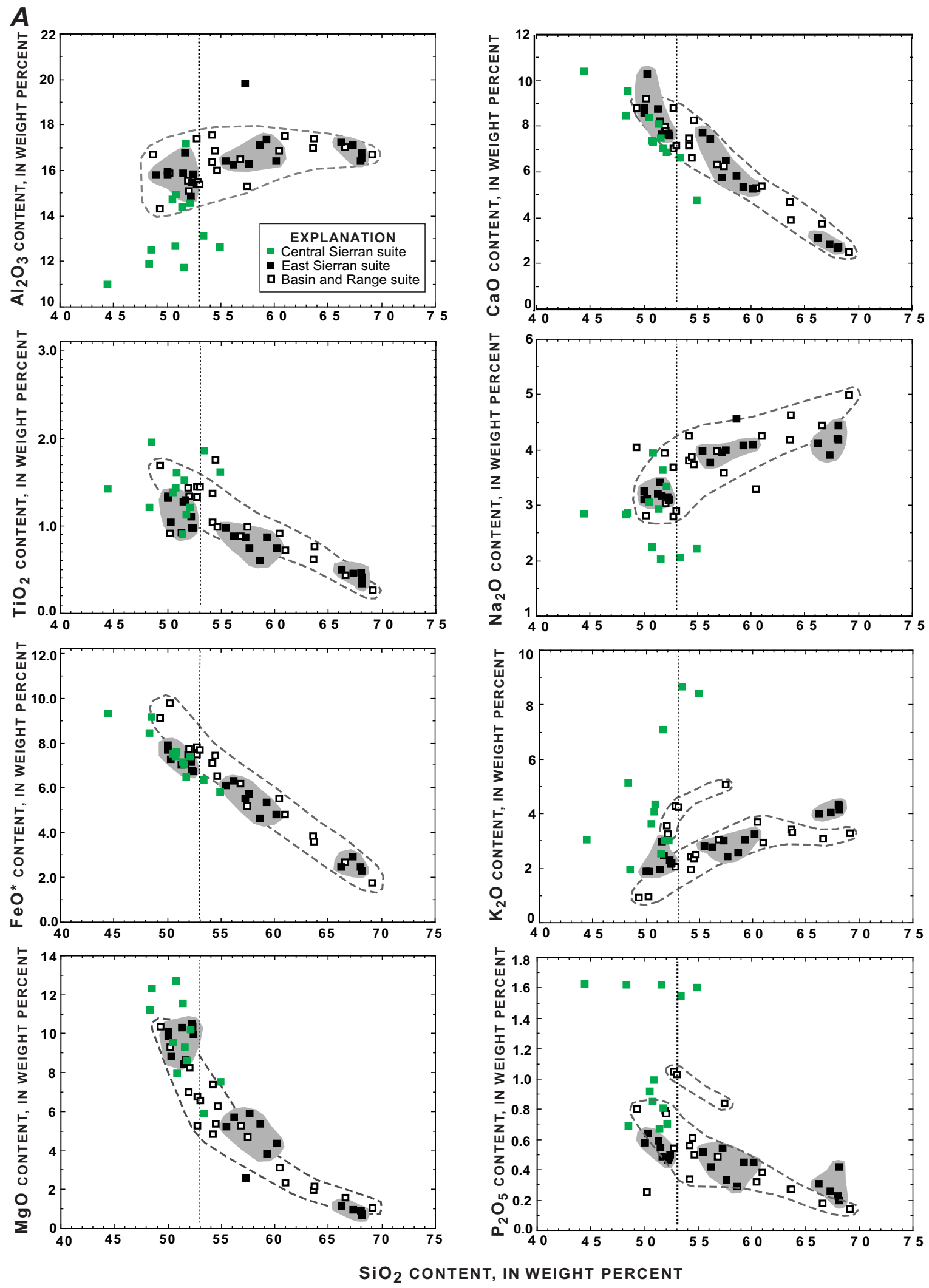

Figure 8. $\mathrm{SiO}_{2}$-variation diagrams for the precaldera Central Sierran, East Sierran, and Basin and Range suites. $A$, Major elements. $B$, Selected trace elements. $C$, Rare-earth elements. Gray shading defines distinct fields of East Sierran basalt, trachyandesite, and dacite, showing compositional gaps; thin dashed outlines define more nearly continuous trend of the Basin and Range suite. Dotted vertical line at 53 weight percent $\mathrm{SiO}_{2}$ marks transition between basalt and trachyandesite. 
$B$
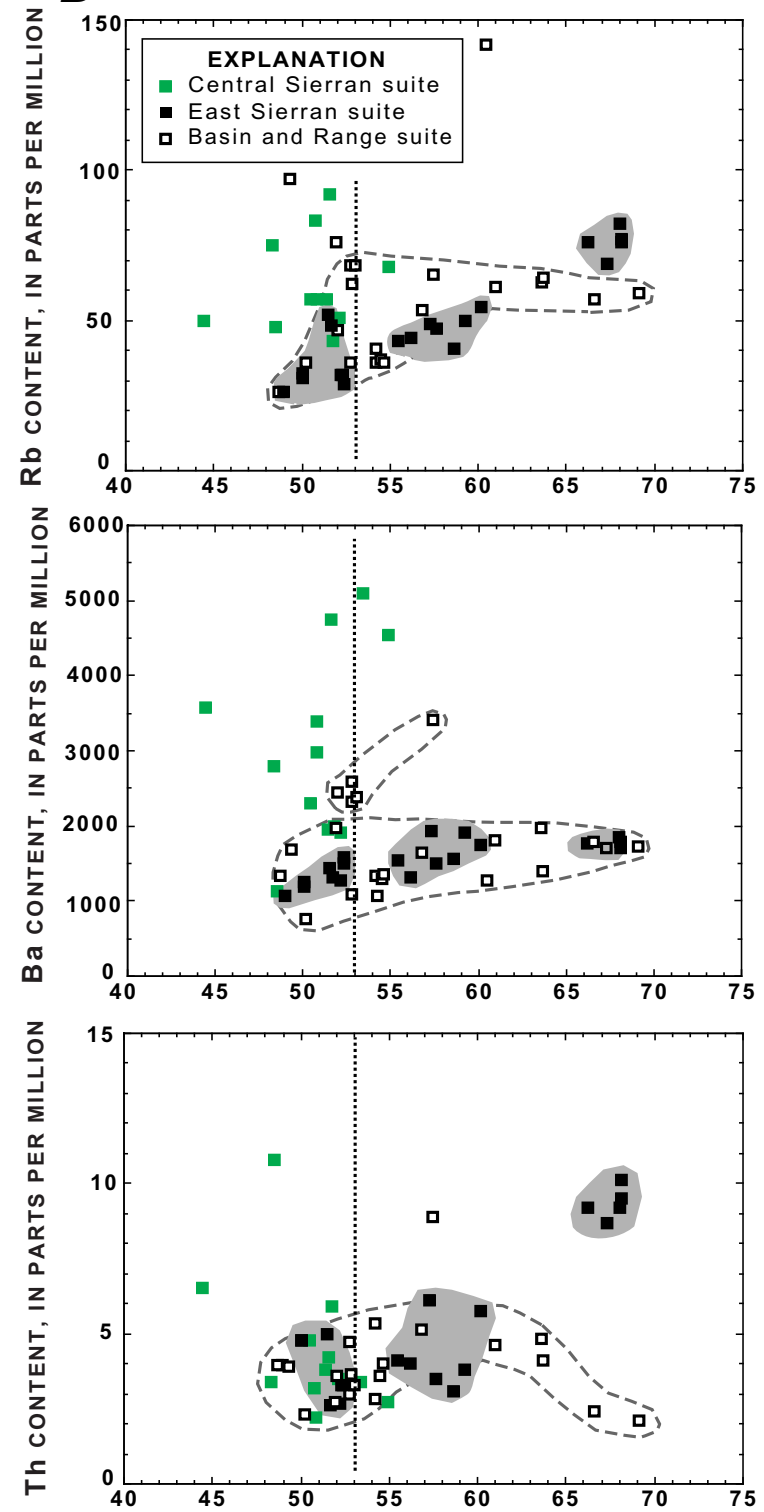

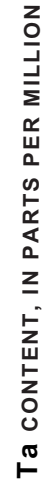

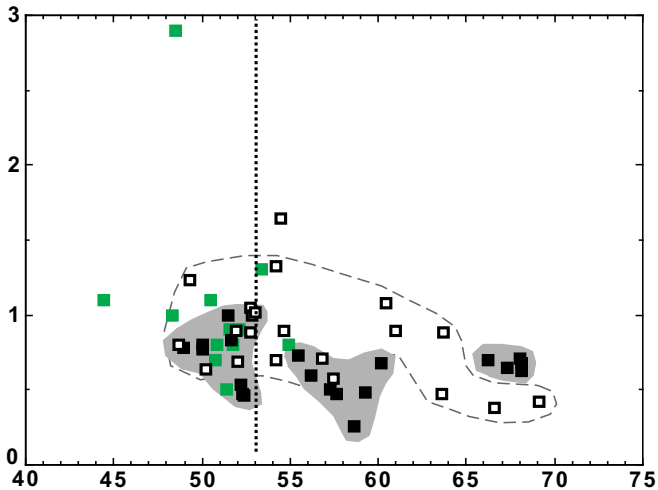

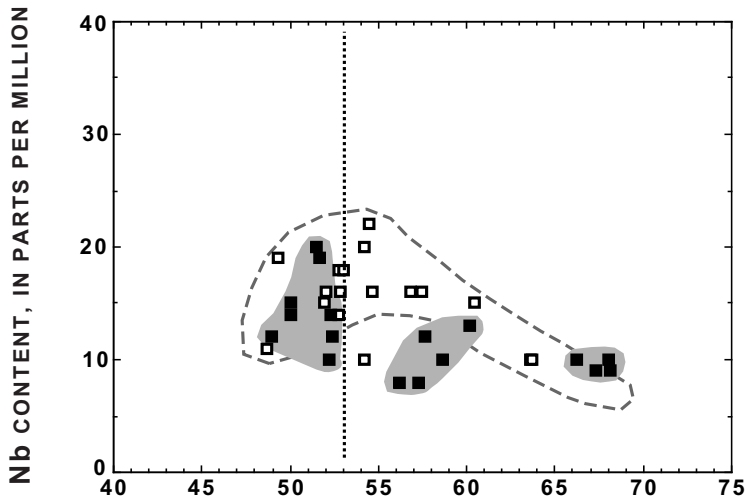
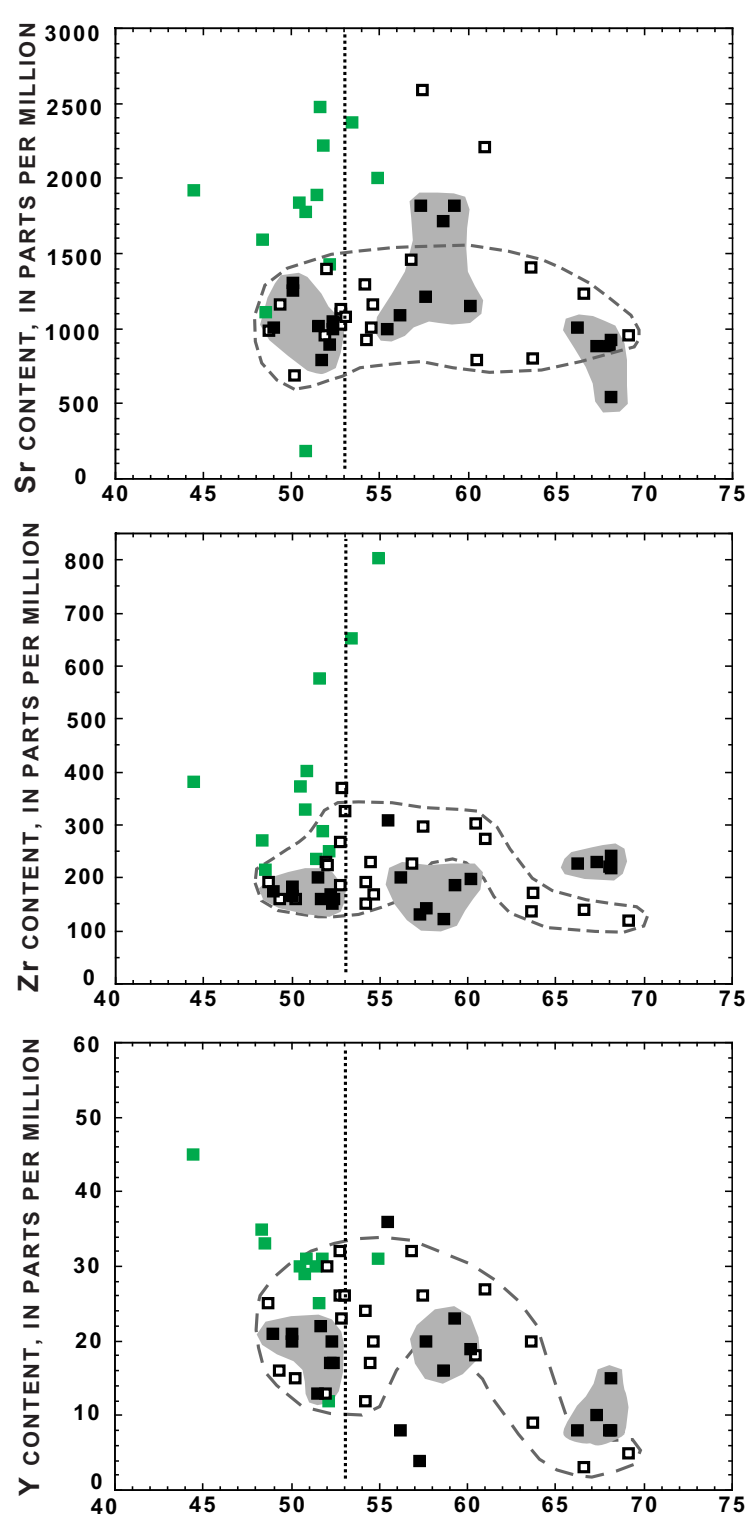

$\mathrm{SiO}_{2}$ CONTENT, IN WEIGHT PERCENT

Figure 8-Continued 

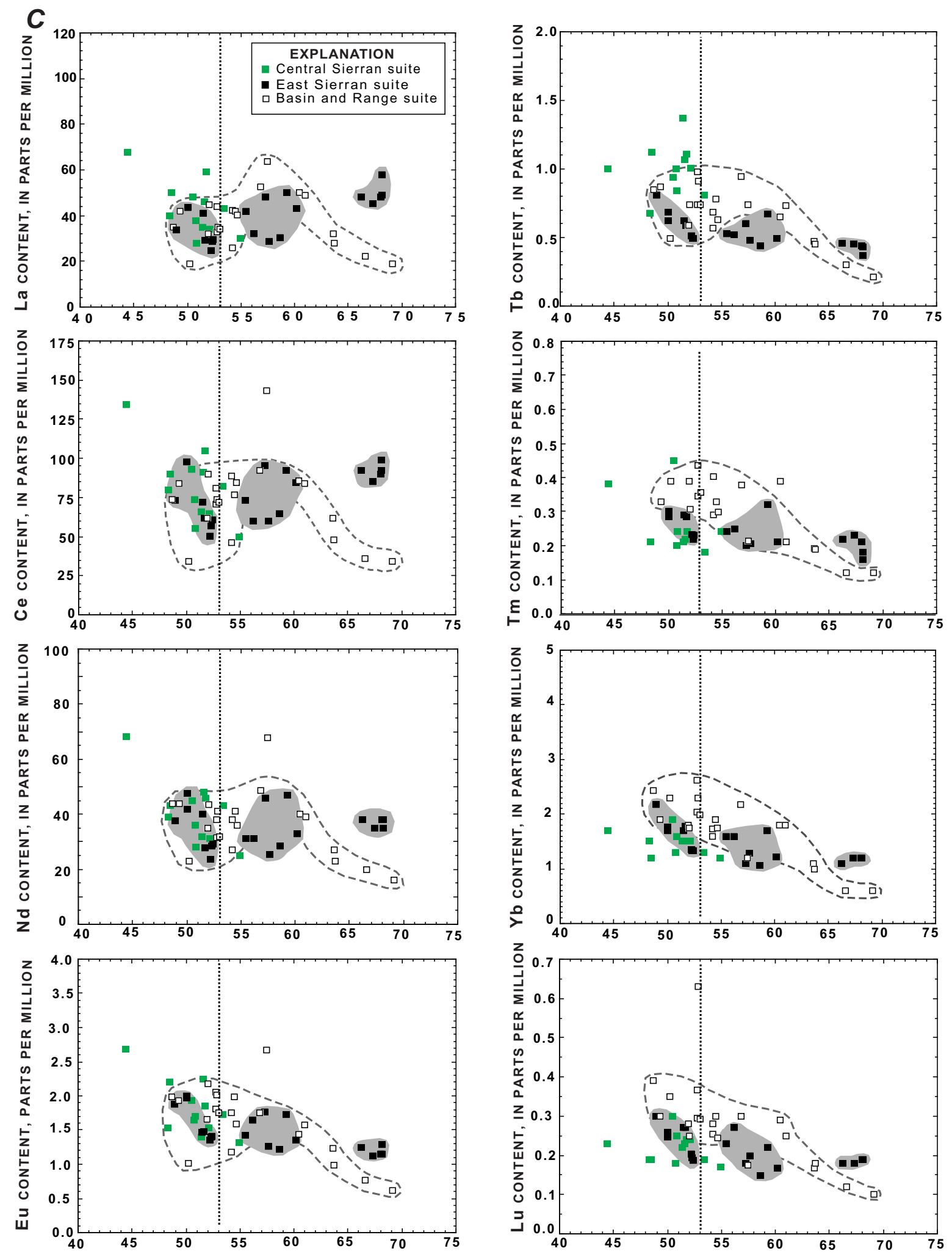

$\mathrm{SiO}_{2}$ CONTENT, IN WEIGHT PERCENT

Figure 8-Continued 


\section{Basalt-Trachyandesite}

In spite of mineralogic and textural similarities, Sierran and Basin and Range basalts ( $\leq 53$ weight percent $\mathrm{SiO}_{2}$ ) differ chemically in both obvious and subtle ways (fig. 8). Most Central and East Sierran basalts have higher (at equivalent $\mathrm{SiO}_{2}$ contents) $\mathrm{MgO}, \mathrm{K}_{2} \mathrm{O}$, and $\mathrm{P}_{2} \mathrm{O}_{5}$ contents and lower $\mathrm{Al}_{2} \mathrm{O}_{3}, \mathrm{TiO}_{2}$, $\mathrm{FeO}^{*}$, and heavy-rare-earth-element (HREE) contents than Basin and Range basalts (figs. 8A, 8C). Ultrapotassic Central Sierran basalts also have mostly higher trace-element contents (Rb, Ba, Sr, Zr, Y), whereas most East Sierran and Basin and
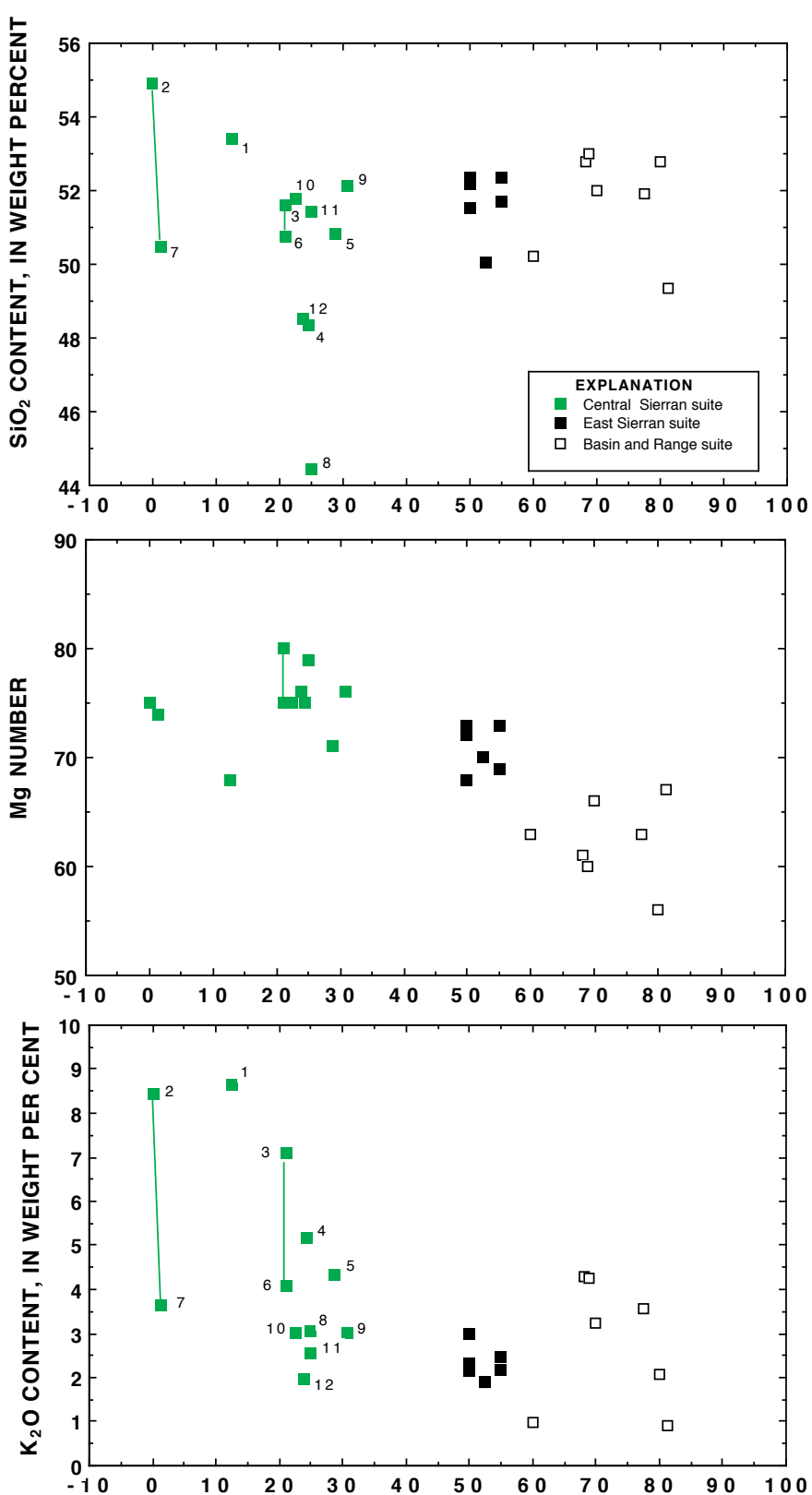

Range basalts are indistinguishable on the basis of these trace elements, including light-rare-earth elements (LREEs) (fig. $8 B, 8 C$ ). Many of these chemical differences are reflected geographically by progressive changes from west to east across the Sierra Nevada-Basin and Range transition (fig. 9). Except for the three westernmost ultrapotassic Central Sierran lavas and the unusually potassic Basin and Range basalts (which probably represent very small degrees of partial melting; see below), $\mathrm{Mg}$ number $(\mathrm{Mg \#}=100 \times \mathrm{MgO} /(\mathrm{MgO}+\mathrm{FeO} *))$ decreases from 71-80 in the Central Sierra, through 68-73 in the East Sierra, to 56-67 in the Basin and Range, whereas
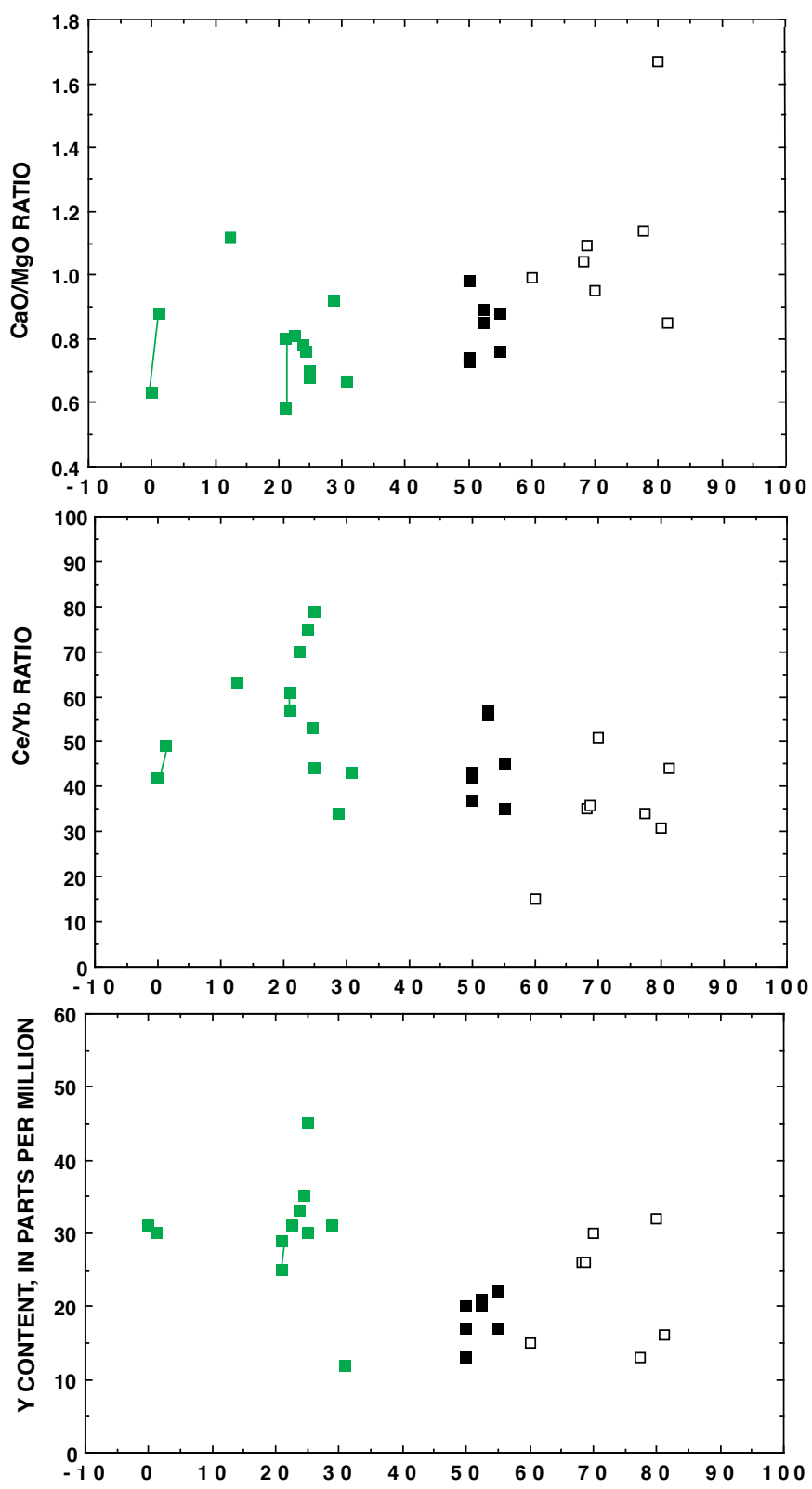

WEST-TO-EAST DISTANCE, IN KILOMETERS

Figure 9. Compositional characteristics of basaltic lavas versus distance from west edge of the Long Valley Volcanic Field, Calif. (0 on abscissa), showing chemical transition through the Central Sierran, East Sierran, and Basin and Range suites, across Sierra Nevada-Basin and Range transition. Solid green lines in the Central Sierran suite connect lavas erupted from same vent. 
$\mathrm{CaO} / \mathrm{MgO}$ ratio increases on average from 0.76 in the Central Sierra, through 0.80 in the East Sierra, to 1.10 in the Basin and Range. Average chondrite-normalized $\mathrm{Ce} / \mathrm{Yb}$ ratios $\left[(\mathrm{Ce} / \mathrm{Yb})_{\mathrm{n}}\right]$ also show a west-to-east-decreasing progression from 14 in the Central Sierra, through 12 in the East Sierra, to 9 in the Basin and Range. $\mathrm{K}_{2} \mathrm{O}$ and $\mathrm{Y}$ contents also generally decrease eastward.

These regional trends also are evident in primitivemantle-normalized trace-element- and chondrite-normalized rare-earth-element (REE) patterns (fig. 10). Although nearly all precaldera basalts have generally similar normalized traceelement patterns - typically enriched in large-ion-lithophile elements (LILEs: Rb, Ba, K, Sr) and depleted in high-fieldstrength elements (HFSEs: Ta, Nb, Ti)—subtle geographic differences are evident: Central Sierra ultrapotassic lavas have generally higher $\mathrm{Rb}, \mathrm{Ba}, \mathrm{K}, \mathrm{Sr}, \mathrm{P}, \mathrm{Zr}$, Tb, and Y contents than East Sierran and Basin and Range basalts. The eastward change in relative $\mathrm{Y}$ content seems particularly significant, wherein Central Sierran potassic lavas are predominantly Y enriched, East Sierran basalts show little Y enrichment or depletion, and Basin and Range basalts show varying $\mathrm{Y}$ enrichment and depletion, in that those enriched in $\mathrm{Y}$ are more alkalic than average and compositionally similar to Central Sierran basalts (see fig. 7B). Central Sierran ultrapotassic basalts show slight negative Eu anomalies (fig. 10), whereas East Sierran and Basin and Range basalts do not. For most elements, Basin and Range basalts (fig. 10) generally vary more widely and change less systematically with $\mathrm{SiO}_{2}$ content than Central and East Sierran basalts.

Comparison of the compositional trends of basalts relative to trachyandesites reveals other significant differences between the East Sierran and Basin and Range suites. For many relatively compatible elements $\left(\mathrm{TiO}_{2}, \mathrm{FeO} * \mathrm{CaO}, \mathrm{P}_{2} \mathrm{O}_{5}\right.$, REEs), the clustered East Sierran basalt analyses (figs. 8A, 8C) show steep negative subtrends with increasing $\mathrm{SiO}_{2}$ content that do not project toward the clustered East Sierran trachyandesitic compositions. In contrast, Basin and Range basalts, though showing considerably more compositional scatter, have compatible-element trends verging toward their associated trachyandesites. This contrast is particularly evident for REE contents (figs. 8C, 10C): East Sierran basalts evolved by depletion of both LREEs and HREEs within a limited $\mathrm{SiO}_{2}$ range, whereas Basin and Range basalts show only slight, if any, REE depletion over a broader $\mathrm{SiO}_{2}$ range.

Most precaldera basalts have primitive-mantle-normalized trace-element signatures resembling those of island-arc basalts (IABs), which in the continental Western United States are generally considered indicative of derivation from a lithospheric-mantle source (see discussion below; Fitton and others, 1988). However, a single alkali-olivine basalt in the Central Sierran suite (sample 12 of Van Kooten, 1980) has a trace-element signature resembling that of ocean-island basalt (OIB). In figure 11, the trace-element signature of this sample is compared with the signature of average OIB (Sun and McDonough, 1989), as well as with the range of signatures for OIB-like basalts from the Coso and Lunar Craters Volcanic
Fields. The sample differs from them only slightly in its higher $\mathrm{Ba}$ and $\mathrm{Th}$ contents and lower $\mathrm{Yb}$ and Lu contents, suggesting contamination by upper-crustal rocks. Such OIB-like basalts in the Basin and Range Province are generally considered to be derived from an asthenospheric-mantle source. The sample 12 flow also is distinctive in containing mafic lithospheric-mantle-derived peridotite and pyroxenite xenoliths (Van Kooten, 1981; Van Kooten and others, 1985), further suggesting a sublithospheric-mantle source.

\section{Dacite}

East Sierran and Basin and Range dacites also show contrasting major- and trace-element compositions and trends (fig. 8). East Sierran dacites have higher $\mathrm{K}_{2} \mathrm{O}, \mathrm{P}_{2} \mathrm{O}_{5}, \mathrm{Rb}$, Th, Ta, Zr, Y, and REE contents than Basin and Range dacites. East Sierran dacites are separated from their associated trachyandesites by a conspicuous compositional gap, whereas Basin and Range dacites form a continuous trend with trachyandesites. This difference between East Sierran and Basin and Range trachyandesite-dacite trends is also evident in chondrite-normalized REE diagrams (fig. 12). East Sierran trachyandesites and dacites (fig. 12A) have weakly sigmoidal patterns, with a relatively small change in REEs with increasing $\mathrm{SiO}_{2}$ content; LREE contents are slightly higher, and HREE contents slightly lower, resulting in a crossover pattern pivotal on Eu. In contrast, Basin and Range trachyandesites and dacites (fig 12B) show straighter patterns and a relatively large overall depletion of REEs with increasing $\mathrm{SiO}_{2}$ content, resulting in a descending parallel pattern. Neither East Sierran nor Basin and Range dacites have significant Eu anomalies. Similar patterns are evident on primitive-mantle-normalized trace-element diagrams (fig. 12): East Sierran dacites, relative to their associated trachyandesites, are enriched in elements more incompatible than $\mathrm{Sr}$ and depleted in elements less incompatible than $\mathrm{Sr}$, whereas Basin and Range dacites, relative to their associated trachyandesites, are progressively depleted in all elements regardless of relative incompatibility. As noted above, these contrasts suggest fundamentally different magmatic processes or different sources for the generation of East Sierran and Basin and Range trachyandesites and dacites (see section below entitled "Evolution of the Precaldera Sequence").

\section{Summary}

Most precaldera basalts have island-arc-like mantle-normalized trace-element signatures, although they are somewhat more enriched in LILEs than typical island-arc basalts. The most significant difference between the East Sierran and Basin and Range suites is that the East Sierran suite shows significant composition gaps between basalt, trachyandesite, and dacite, whereas the Basin and Range suite shows a relatively continuous evolutionary trend from basalt to dacite. Central and East Sierran basalts have higher $\mathrm{MgO}, \mathrm{K}_{2} \mathrm{O}$, and $\mathrm{P}_{2} \mathrm{O}_{5}$ contents and lower $\mathrm{Al}_{2} \mathrm{O}_{3}, \mathrm{TiO}_{2}, \mathrm{FeO}$, and HREE contents than Basin and Range basalts. Geographically, these differences are reflected by progressive west-to-east decreases in $\mathrm{Mg}$ 

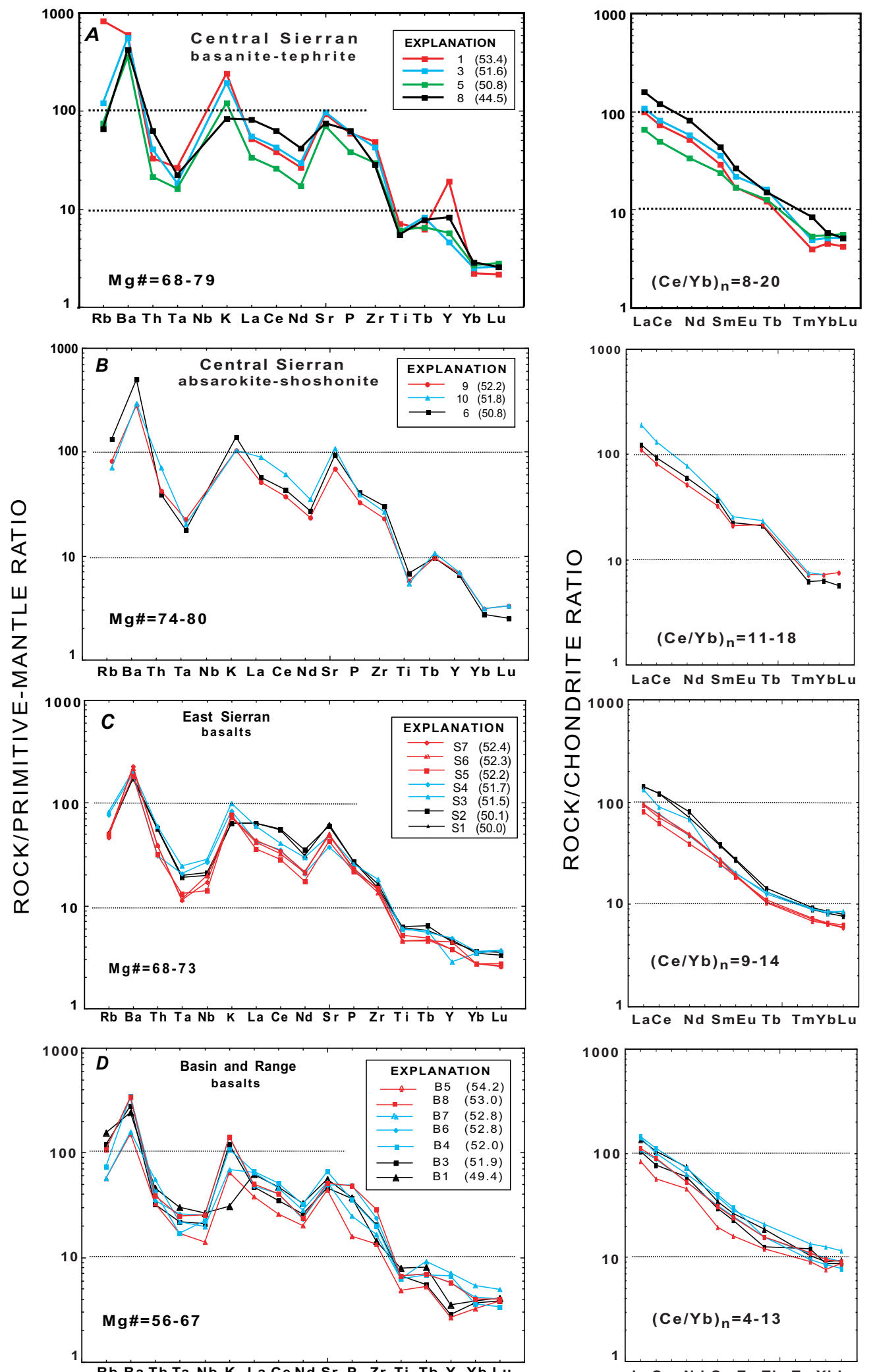
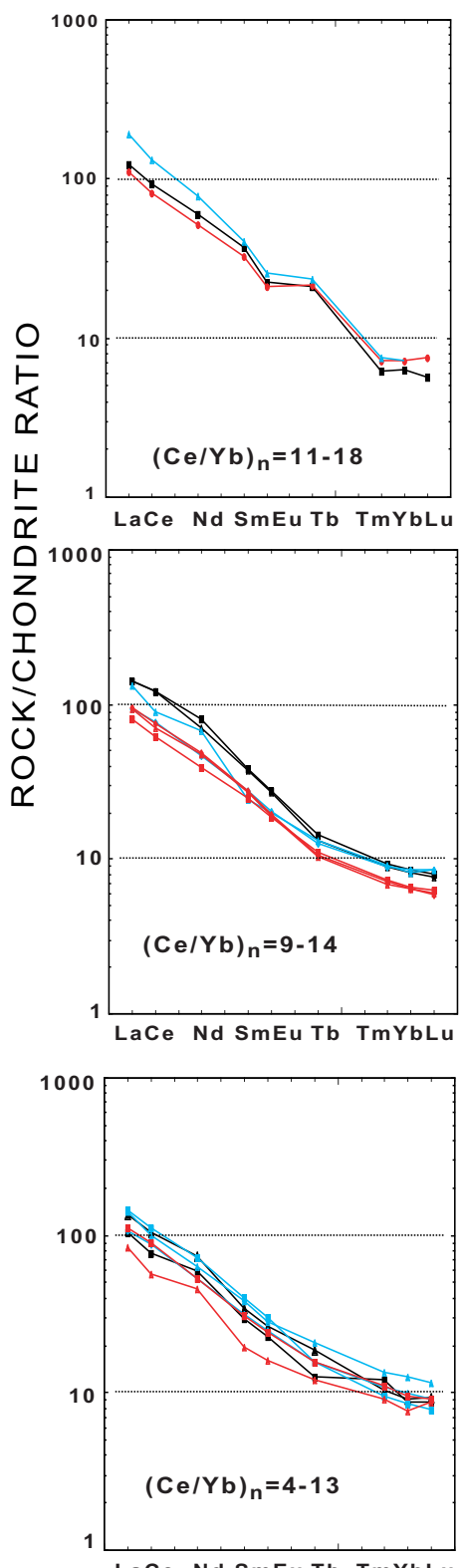

Figure 10. Variations in primitive-mantle-normalized trace-element and chondrite-normalized rare-earth-element contents of precaldera mafic lavas. $A$, Central Sierran basanite-tephrite lavas (data from Van Kooten, 1980). $B$, Central and East Sierran alkali basalt (data from Van Kooten, 1980). C, East Sierran basalt. $D$, Basin and Range basalt. Numbers in explanations refer to samples 1 through 12 of Van Kooten (1980) and samples listed in tables 2 and 3 ; numbers in parentheses are $\mathrm{SiO}_{2}$ contents (in weight percent). Mg\#, magnesium number. $(\mathrm{Ce} / \mathrm{Yb})_{n}$, chondrite-normalized $\mathrm{Ce} / \mathrm{Yb}$ ratio. 
number, $\mathrm{K}_{2} \mathrm{O}$ content, $\mathrm{Ce} / \mathrm{Yb}$ ratio, and $\mathrm{Y}$ content across the Sierra Nevada-Basin and Range transition. Chondrite-normalized REE patterns of East Sierran trachyandesites and dacites indicate simultaneous enrichment of LREEs and depletion of HREEs, whereas chondrite-normalized patterns of Basin and Range trachyandesites and dacites indicate evolution by

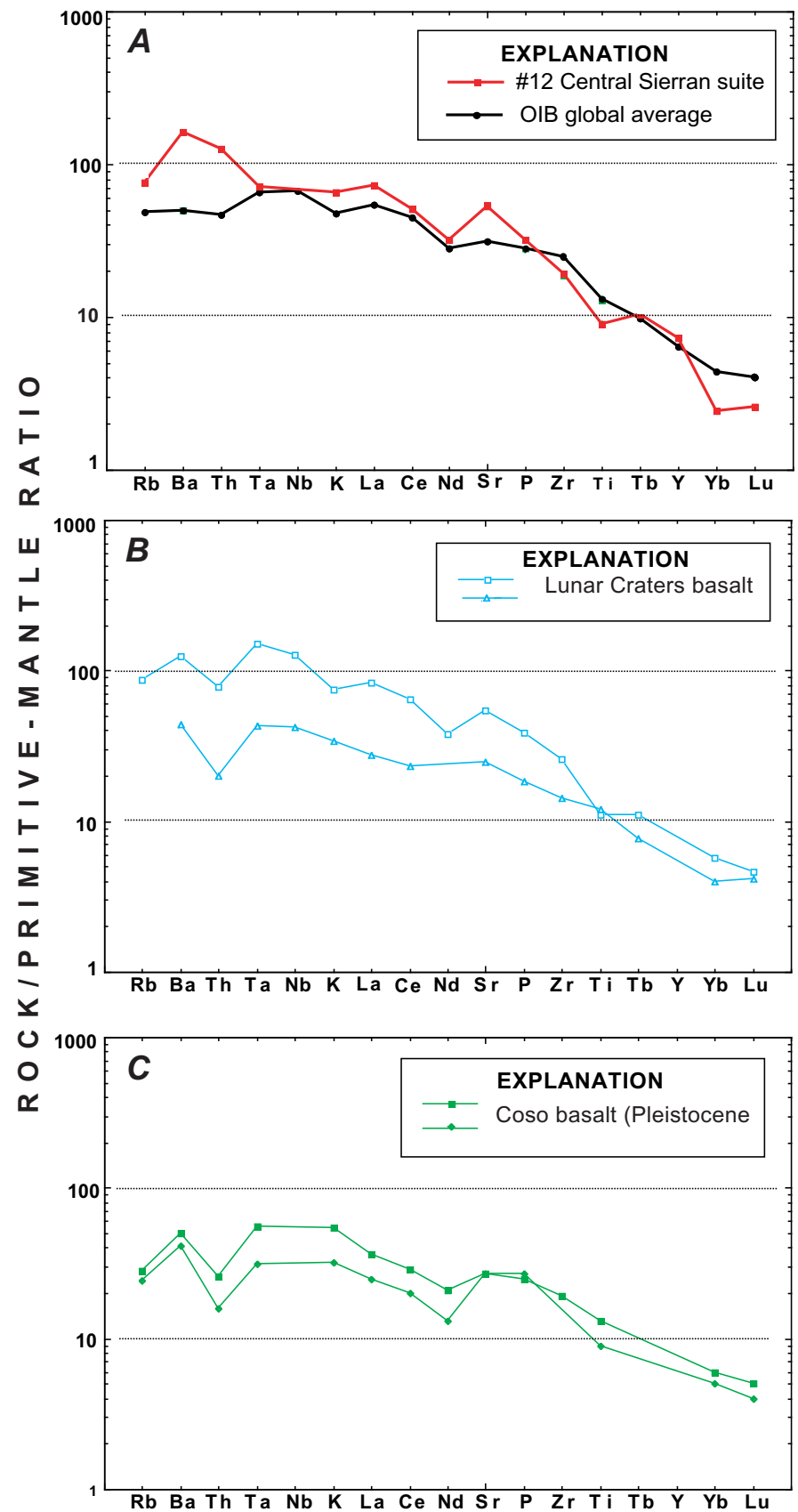

Figure 11. Variations in primitive-mantle-normalized trace-element contents of ocean-island-basalt (OIB)-like lavas. $A$, Long Valley: alkali-olivine basalt sample 12 (Van Kooten, 1980) in comparison with OIB global average (Sun and McDonough, 1989). $B$, Lunar Craters Volcanic Field (Lum and others, 1989). C, Coso Volcanic Field (Bacon and Metz, 1984). Higher-than-average $\mathrm{Ba}$, Th, and Sr contents in sample 12 (fig. 11A) may be due to cryptic crustal contamination. progressive depletion of all REEs. The contrasting chemistries of East Sierran and Basin and Range basalts suggest derivation from different sources, and the divergent trends of their associated trachyandesites and dacites suggest an origin involving different magmatic processes.

\section{Postcaldera Sequence}

Postcaldera lavas in both the Caldera and Mono-Inyo suites are bimodal, with compositional gaps between trachyandesites and dacites (figs. $7 C, 7 D, 13$ ) but not between basalts and trachyandesites. In the Caldera suite, the single sample within the trachyandesite-dacite gap (59-64 weight percent $\mathrm{SiO}_{2}$ ) is the hybrid "olivine-quartz latite" flow (sample C12, table 4), which, on the basis of petrography and chemistry, clearly is a commingled basalt and dacite. In the Mono-Inyo suite, the trachyandesitic-dacitic compositional gap is broader at lower $\mathrm{SiO}_{2}$ contents (54-63 weight percent $\mathrm{SiO}_{2}$ ), and all the samples within the gap represent extremely small volume mafic enclaves in dacite and rhyolite lavas that clearly represent mixed basalthost hybrids. The Caldera suite has slightly higher total alkali contents (both $\mathrm{K}_{2} \mathrm{O}$ and $\mathrm{Na}_{2} \mathrm{O}$ ) than the Mono-Inyo suite (figs. $7 C, 7 D, 13 A$ ), as reflected in their Peacock alkali-lime indices of 56.2 and 57.5, respectively. The Caldera suite also has generally higher $\mathrm{P}_{2} \mathrm{O}_{5}$ and REE contents (figs. 13A, 13C).

\section{Basalt-Trachyandesite}

Caldera and Mono-Inyo basalts differ in subtle but significant ways. Like the suite as a whole, Caldera basalts have slightly higher total alkali contents than Mono-Inyo basalts (fig. 7C, 7D). The most mafic and oldest Caldera basalts $(\leq 50$ weight percent $\mathrm{SiO}_{2}, \mathrm{Mg \# >60)}$ include the Early Rhyolite mafic enclaves (sample $\mathrm{C} 1$, table 4), corehole Inyo-4 group $\mathrm{V}$ breccias, and two older flows in the south and west moats (samples C3, C4, table 4). Caldera basalts and trachyandesites show a nearly continuous range in composition up to about 58 weight percent $\mathrm{SiO}_{2}$ but generally cluster into five progressively more silicic compositional groups, particularly evident in the corehole Inyo-4 samples (Vogel and others, 1994). The uppermost moat flows (intracaldera basalt-trachyandesite, fig. 13; USGS analyses) have slightly higher $\mathrm{Na}_{2} \mathrm{O}, \mathrm{K}_{2} \mathrm{O}, \mathrm{P}_{2} \mathrm{O}_{5}$, and REE contents than the corehole Inyo-4 flows (Michigan State University analyses), suggesting that these uppermost flows may constitute a slightly more evolved chemical group (see subsection above entitled "Late Intracaldera Basalt-Trachyandesite Lavas"), but this difference could be due to analytical differences between the two laboratories.

On mantle-normalized trace-element diagrams (fig. 14), nearly all Caldera basalts, including the Buttresses and Horseshoe Lake flows (fig. 14A), the most mafic basalts (fig. $14 B$ ), and the more evolved porphyritic basalts (fig. 14C), are characteristically depleted in K relative to La. On chondrite-normalized REE diagrams, the sparsely phyric, parental Caldera basalts (fig. 14B) have relatively low LREE contents and moderate $(\mathrm{Ce} / \mathrm{Yb})_{\mathrm{n}}$ ratios $(5)$, whereas the more evolved 
porphyritic basalts (fig. 14C) have higher LREE contents and higher $(\mathrm{Ce} / \mathrm{Yb})_{\mathrm{n}}$ ratios $(8-11)$. Normalized trace-element patterns of Mono-Inyo basalts resemble those of Caldera basalts, except that Mono-Inyo basalts have more coherent patterns and apparent higher $\mathrm{K} / \mathrm{La}$ ratios, resulting in a distinct $\mathrm{K}$ peak; however, this difference is due to their lower REE contents (figs. 14D) rather than higher K contents. Mono-Inyo basalts have sigmoidal rather than straight chondrite-normalized REE patterns but, like the most mafic Caldera basalts, have low $(\mathrm{Ce} / \mathrm{Yb})_{\mathrm{n}}$ ratios $(6-8)$.

The Buttresses and Horseshoe Lake basalts, though temporally in the postcaldera sequence, plot within the precaldera East Sierran basalt range on $\mathrm{Al}_{2} \mathrm{O}_{3^{-}}, \mathrm{TiO}_{2^{-}}, \mathrm{FeO}^{*}$, $\mathrm{MgO}-, \mathrm{CaO}-, \mathrm{K}_{2} \mathrm{O}$-, and $\mathrm{Ba}_{-} \mathrm{SiO}_{2}$-variation diagrams (figs. $13 A, 13 B)$ and are significantly more mafic than all other postcaldera basalts: the Buttresses with an $\mathrm{Mg}$ number of 72 and Horseshoe Lake with an Mg number of 70. Like other Caldera basalts, however, both the Buttresses and Horseshoe Lake basalts are depleted in K relative to La (fig. 14A), partly because of their unusually high LREE contents. Thus, they have attributes of both precaldera East Sierran basalts and postcaldera Caldera basalts.

\section{Dacite-Rhyolite}

The dacite lavas of the Caldera and Mono-Inyo suites, like the basalts and trachyandesites, also differ in subtle ways. Caldera "dacites" have higher total alkali contents than Mono-Inyo dacites, owing mainly to their higher $\mathrm{Na}_{2} \mathrm{O}$ contents (figs $7 C$, 7D); thus, in the IUGS classification, they plot as trachydacite rather than dacite. Caldera trachydacites also have higher $\mathrm{Al}_{2} \mathrm{O}_{3}$ contents (fig. 13A) and slightly lower $\mathrm{FeO}^{*}, \mathrm{MgO}$, and $\mathrm{CaO}$ contents than Mono-Inyo dacites, as well as generally higher $\mathrm{Ba}, \mathrm{Zr}$, Y (fig. 13B), and most REE contents (fig. 13C). These differences are particularly evident in normalized trace-element and REE diagrams (fig. 15). Porphyritic dacites of both suites (figs. $15 B, 15 C$ ) have generally similar profiles, but relative to crystal-poor dacites (fig. 15A) they are more depleted in $\mathrm{Sr}, \mathrm{P}$, and $\mathrm{Ti}$ and more enriched in $\mathrm{Rb}, \mathrm{K}$, and $\mathrm{Zr}$, resulting in more sharply spiked patterns. The porphyritic dacites have small negative Eu anomalies, whereas the crystal-poor dacites do not, indicating that the porphyritic dacites underwent plagioclase fractionation but the crystal-poor dacites did not. The low-SiO rhyolites of both suites (fig. 15D) are generally similar; relative to their associated dacites, they are more strongly depleted in
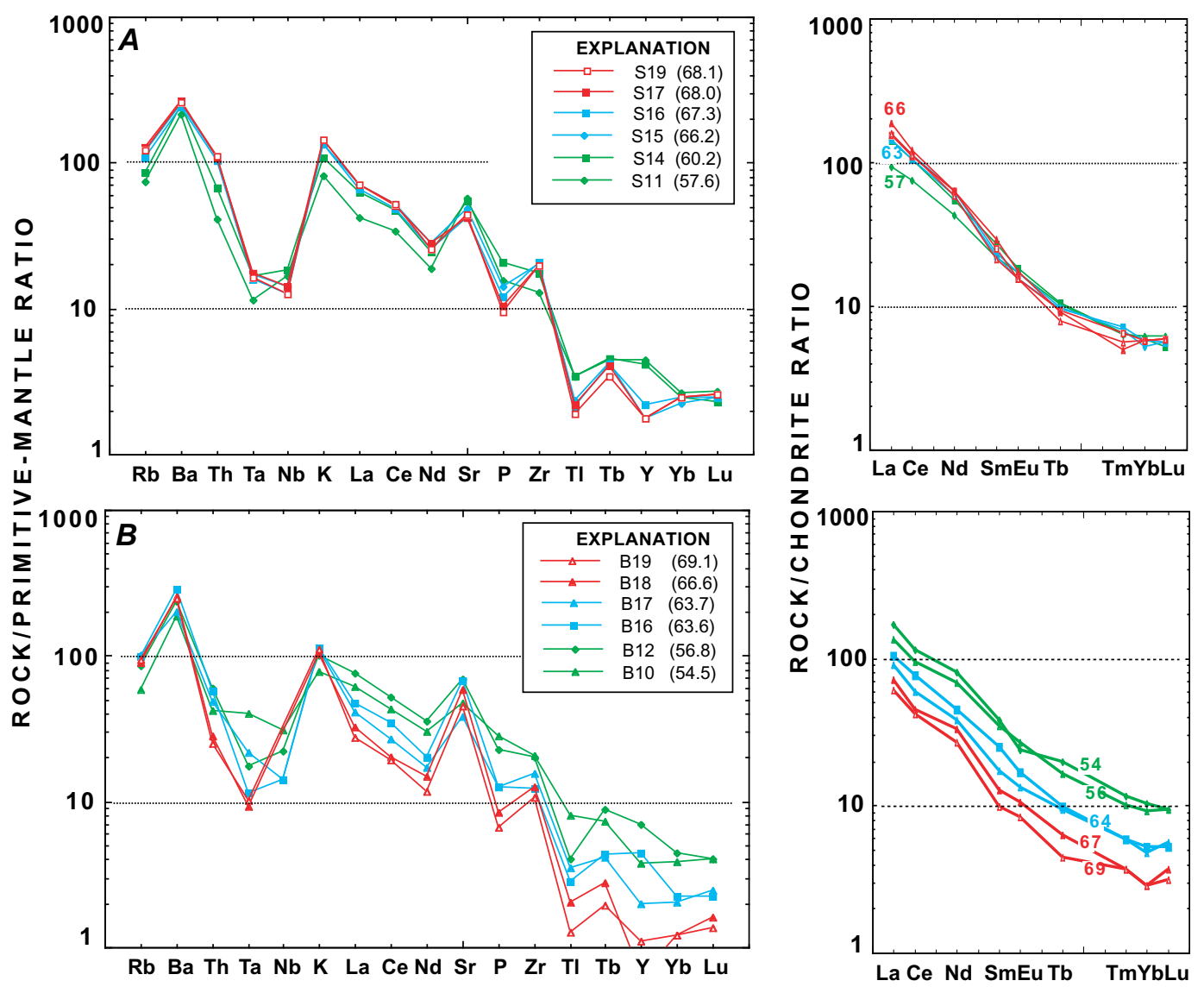

Figure 12. Variations in primitive-mantle-normalized trace-element and chondrite-normalized rare-earthelement contents of precaldera trachyandesite-dacite lavas. $A$, East Sierran lavas. $B$, Basin and Range lavas. Note contrasting crossover and parallel patterns of East Sierran and Basin and Range lavas, respectively, and greater compositional change in Basin and Range lavas. Numbers in explanations denote samples listed in tables 2 and 3; numbers in parentheses and on figures are $\mathrm{SiO}_{2}$ contents (in weight percent). 

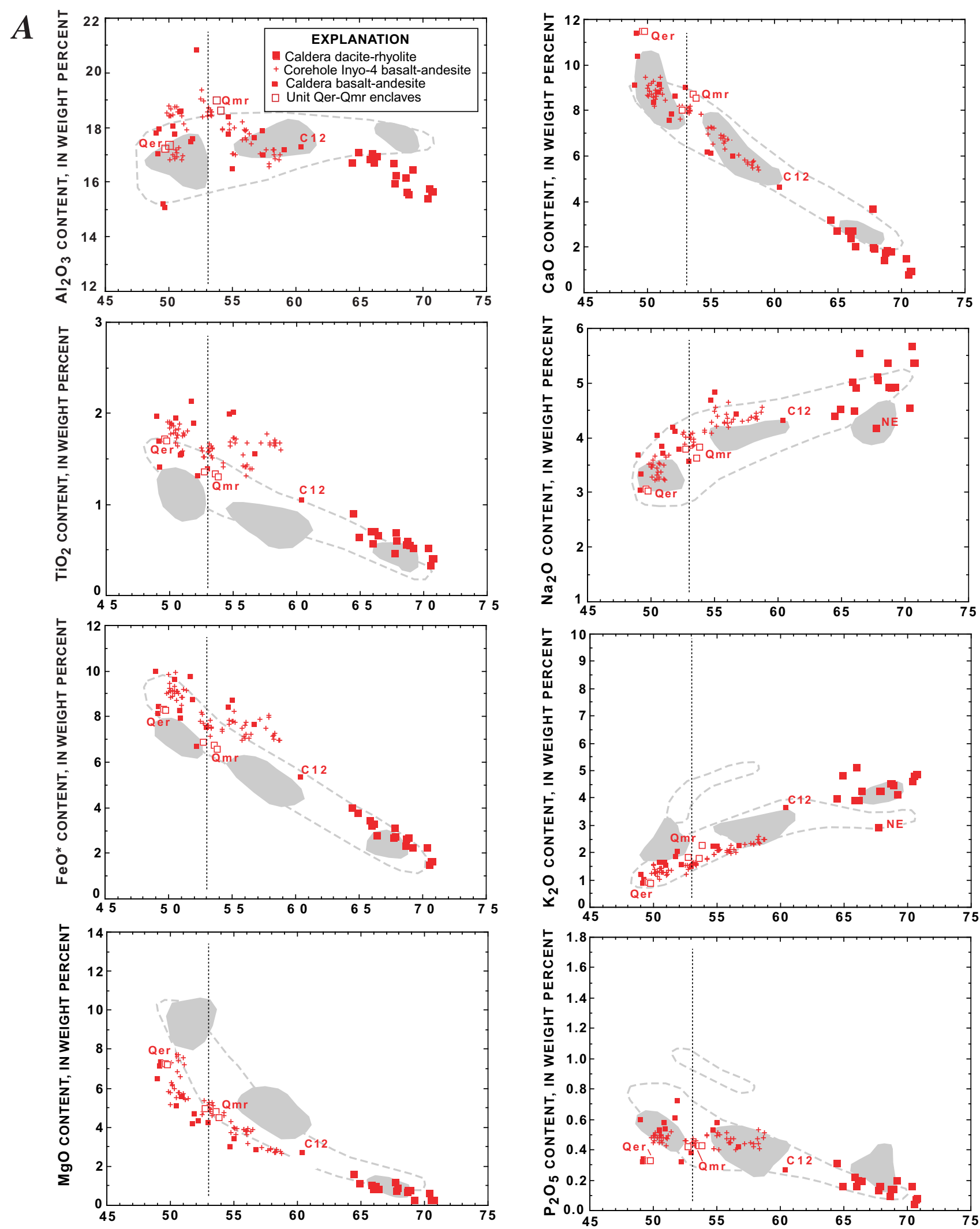

$\mathrm{SiO}_{2}$ CONTENT, IN WEIGHT PERCENT

Figure 13. Comparative $\mathrm{SiO}_{2}$-variation diagrams for the Caldera and Mono-Inyo suites of postcaldera sequence. $A, A^{\prime}$, Major elements. $B, B^{\prime}$, Selected trace elements. $C, C^{\prime}$, Rare-earth elements. Light-gray shading and thin dashed outlines in figures $13 A, 13 B$, and $13 C$ define trends of the East Sierran and Basin and Range suites, respectively, for comparison. 

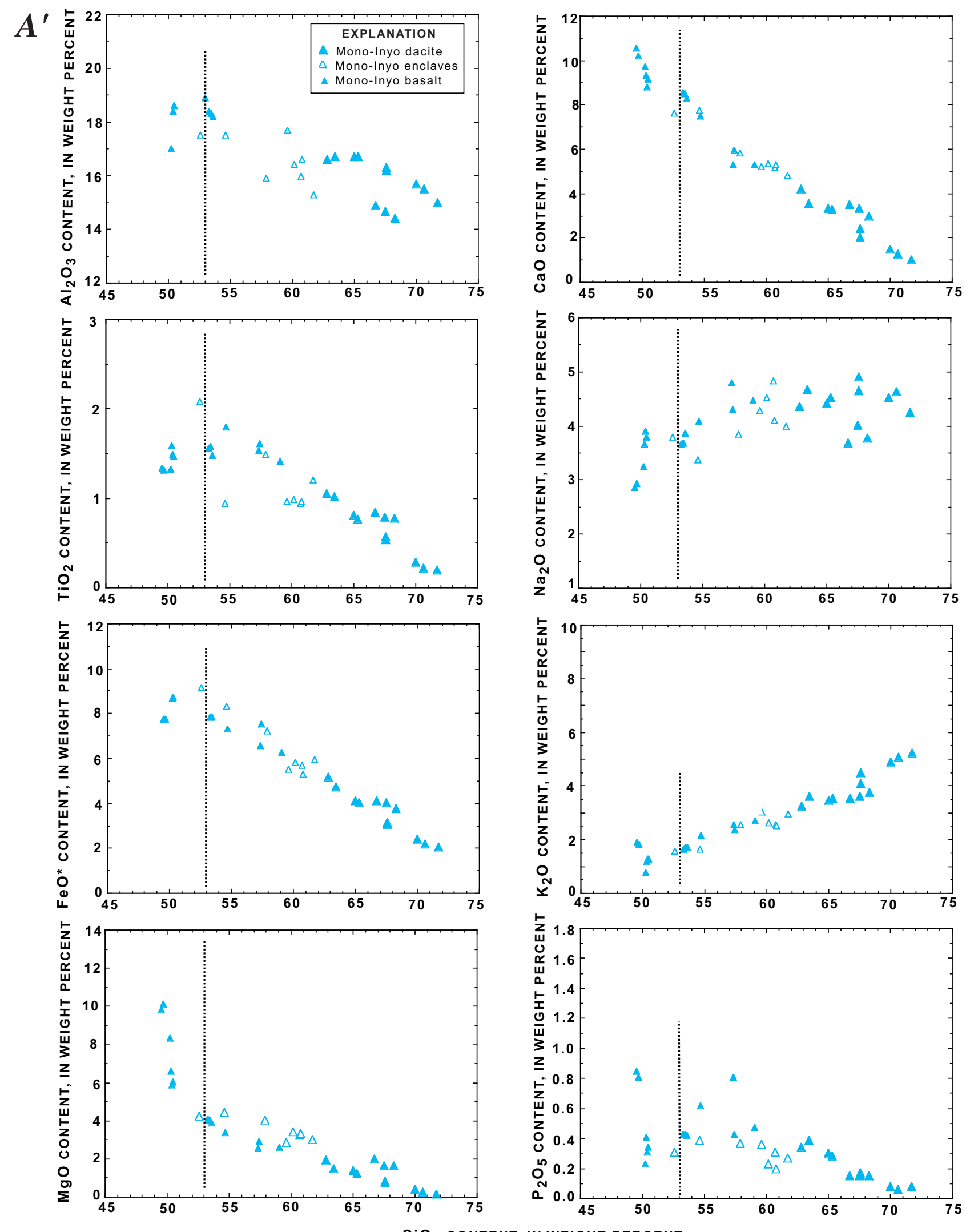

Figure 13-Continued 

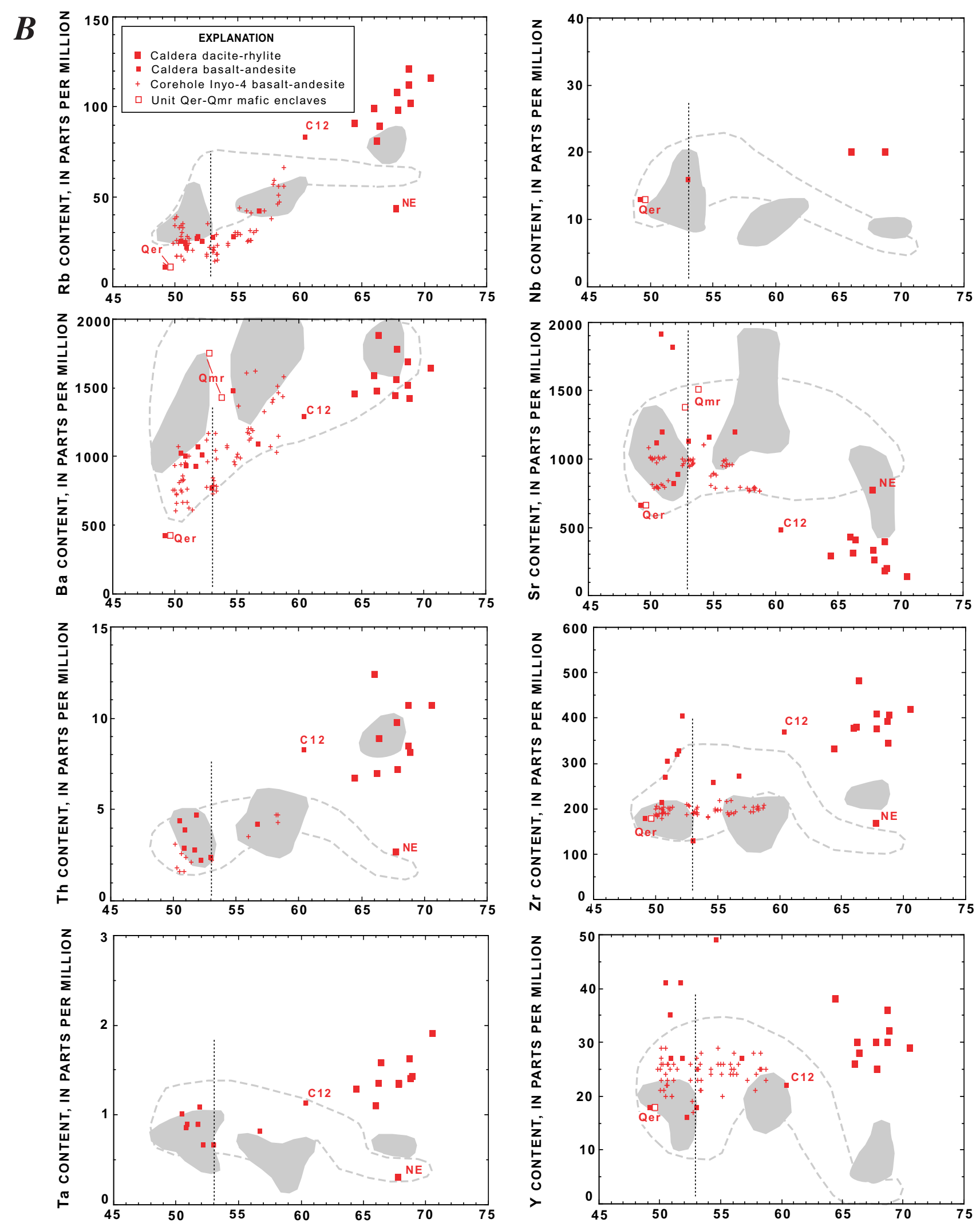

$\mathrm{SiO}_{2}$ CONTENT, IN WEIGHT PERCENT

Figure 13-Continued 

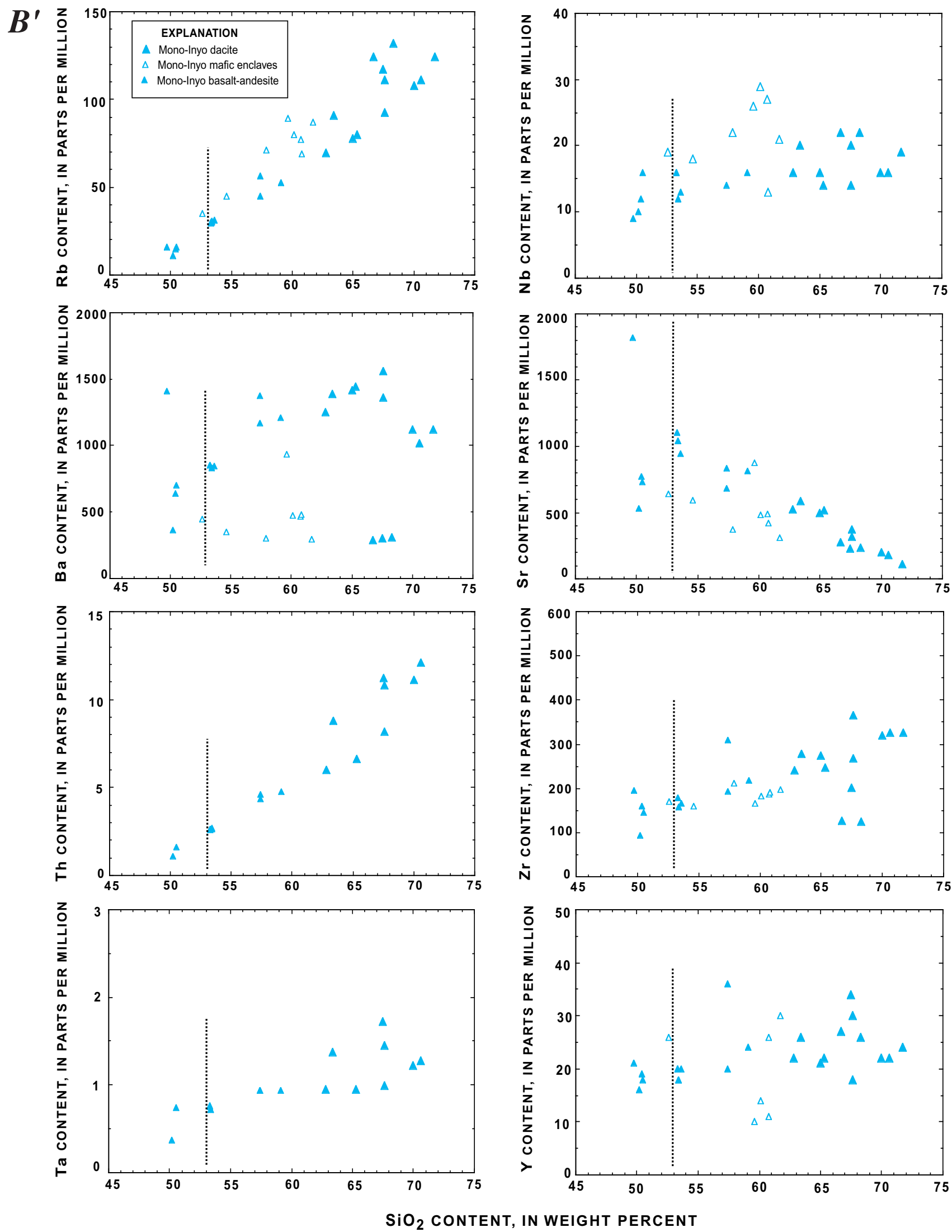

Figure 13-Continued 

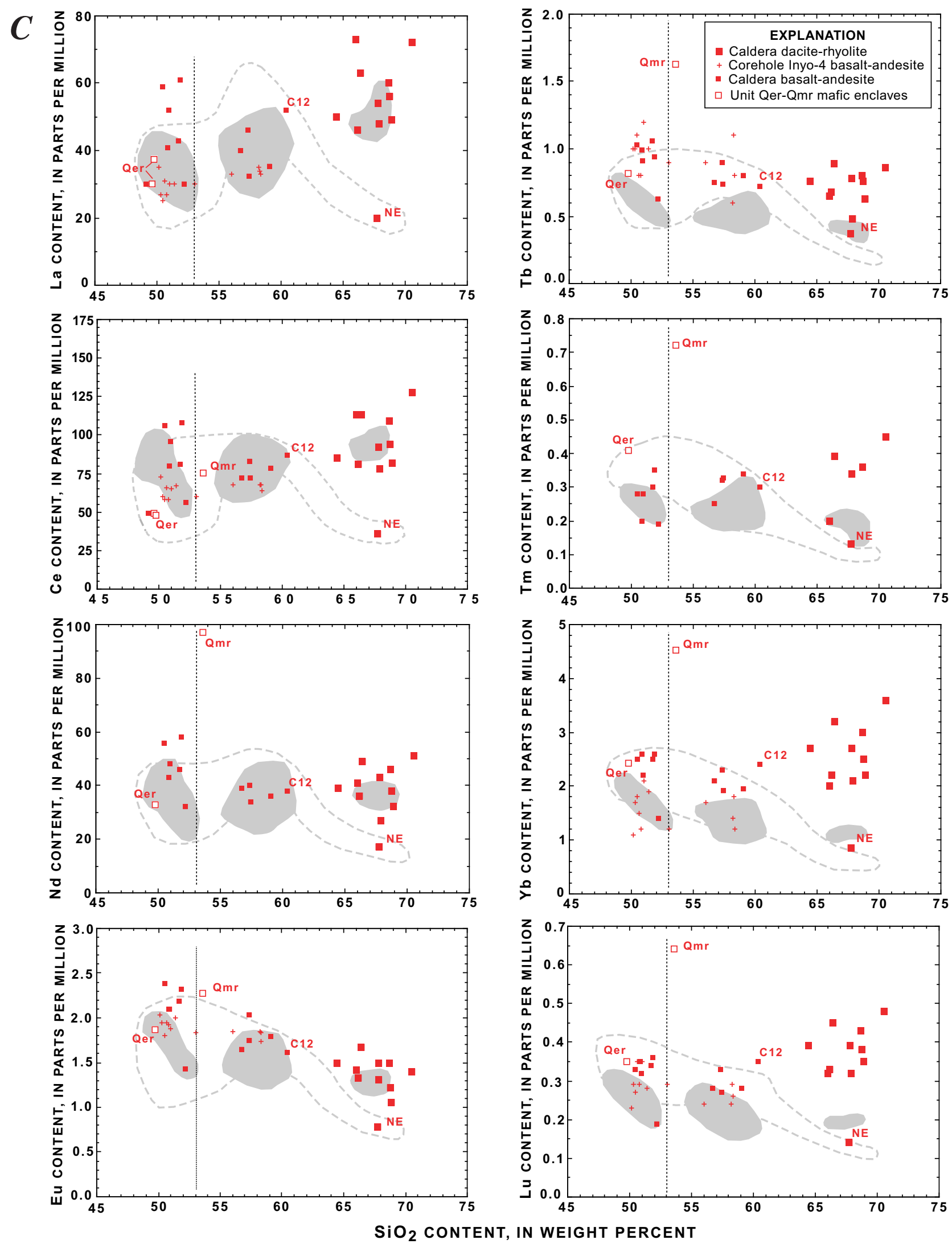

Figure 13-Continued 

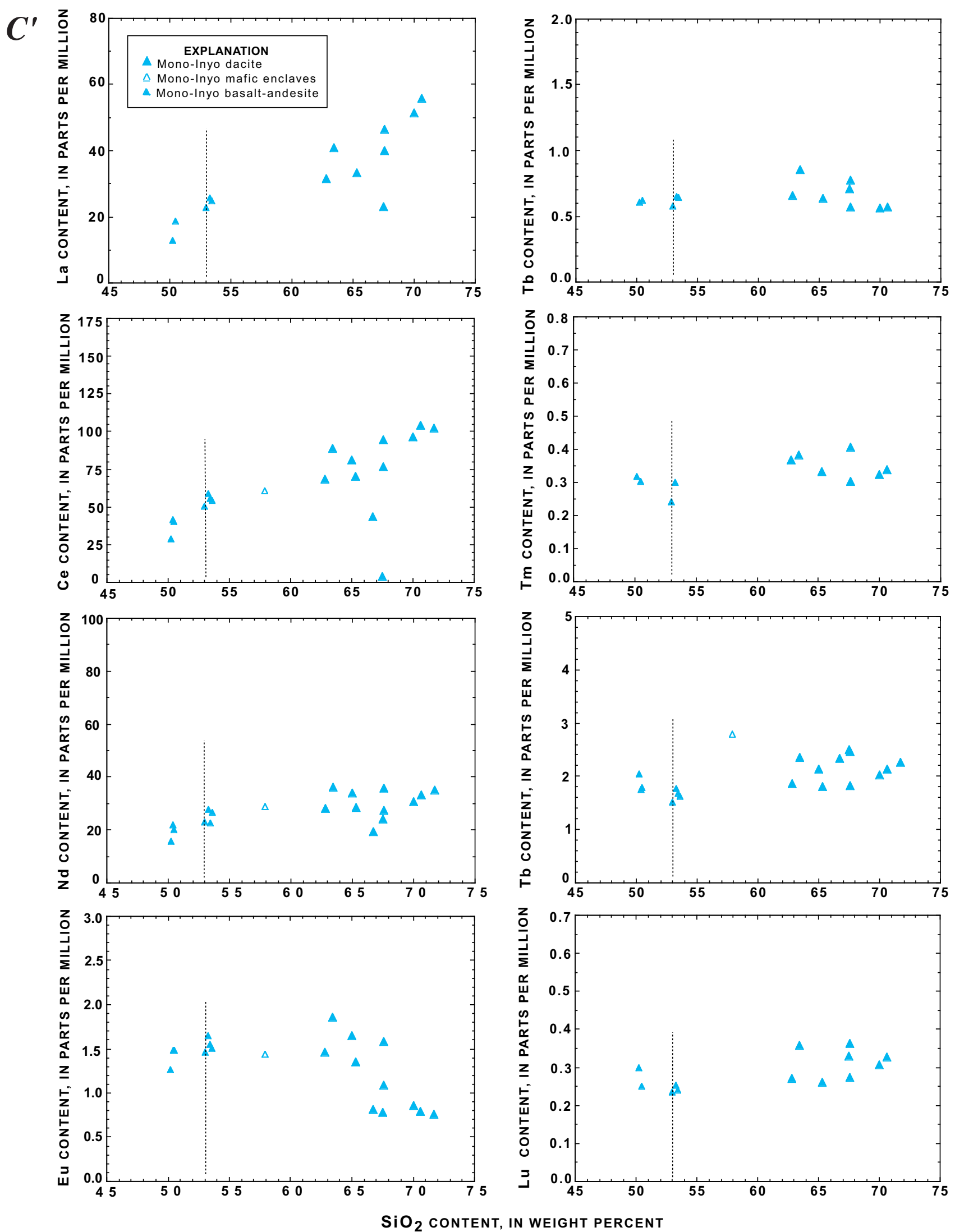

Figure 13-Continued 

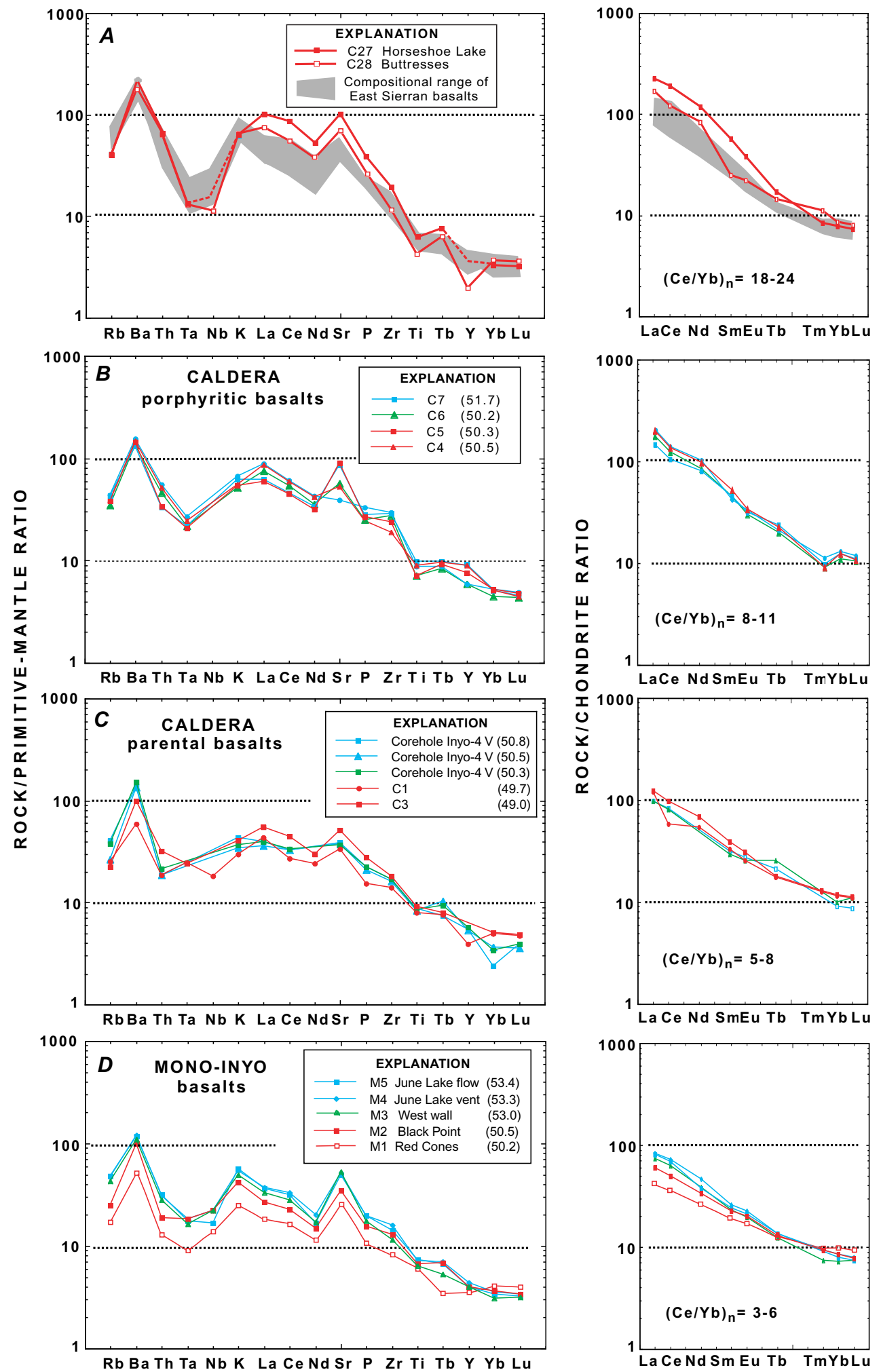

Figure 14. Variations in primitive-mantle-normalized trace-element and chondrite-normalized rare-earth-element contents of postcaldera basalts. $A$, Buttresses and Horseshoe Lake basalts relative to compositional range of East Sierran basalts. $B$, Caldera porphyritic basalts. $C$, Caldera parental basalts. $D$, Mono-Inyo basalts. Numbers in explanations refer to samples in tables 4 and 5 ; numbers in parentheses are $\mathrm{SiO}_{2}$ contents. Note progressively lower light-rare-earth-element (LREE) contents (lower (Ce/ $\mathrm{Yb})_{n}$ ratios) from figures $14 A$ through $14 D$, particularly low trace-element and LREE contents in the Black Point and Red Cones basalts in figure 14D. 

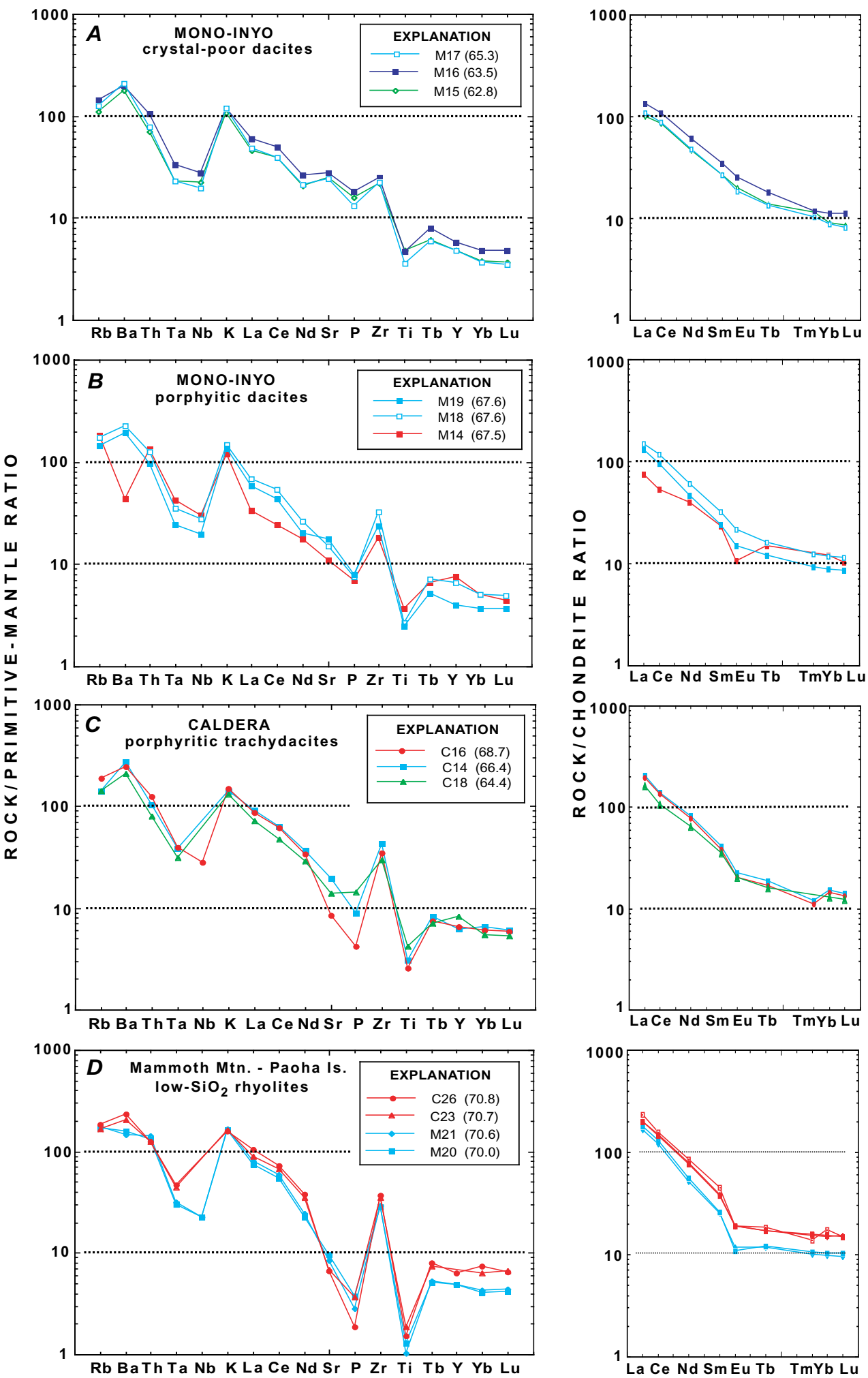

Figure 15. Variations in primitive-mantle-normalized trace-element and chondrite-normalized rare-earth-element contents of postcaldera dacites and rhyolites. $A$, Mono-Inyo aphyric dacites. $B$, Mono-Inyo porphyritic dacites. $C$, Caldera porphyritic dacites. $D$, Caldera (Mammoth Mountain) and Mono-Inyo (Paoha Island) low-SiO${ }_{2}$ rhyolites. Numbers in explanations refer to samples listed in tables 4 and 5; numbers in parentheses are $\mathrm{SiO}_{2}$ contents (in weight percent). Note progressive decrease in $\mathrm{Sr}, \mathrm{P}$, and $\mathrm{Ti}$ contents and increase in Eu anomaly from figures $15 A$ through $15 D$. 
Sr, P, and Ti. Mammoth Mountain rhyolites (Caldera suite) and Paoha Island rhyolites (Mono-Inyo suite) have moderate negative Eu anomalies. Mono-Inyo rhyolites are noticeably more depleted in REEs than Caldera rhyolites.

\section{Summary}

Both the Caldera and Mono-Inyo suites are bimodal, with compositional gaps between trachyandesite and trachydacite/ dacite. The few samples within these gaps represent small-volume mafic enclaves in dacite and rhyolite lavas produced by mixing of basaltic magma with the host rocks. The most mafic, presumed parental, Caldera and Mono-Inyo basalts have low LREE contents and low $(\mathrm{Ce} / \mathrm{Yb})_{\mathrm{n}}$ ratios, suggesting derivation from an LREE-depleted source. Caldera basalts, including the Buttresses and Horseshoe Lake basalts, typically are depleted in mantle-normalized $\mathrm{K}$ relative to La. Although both Caldera and Mono-Inyo basalts have similar $\mathrm{K}_{2} \mathrm{O}$ contents, Mono-Inyo basalts have lower LREE contents, giving them a distinctive $\mathrm{K}$ peak on mantle-normalized diagrams (K/La ratios $>1$ ). Significantly, all Mono-Inyo lavas (basalts through rhyolites) have lower REE contents than comparable Caldera lavas. Caldera basalts and trachyandesites fall into five cyclical groups, each at progressively higher ranges in $\mathrm{SiO}_{2}$ content.

Caldera trachydacites are generally more coarsely porphyritic than Mono-Inyo dacites. Caldera trachydacites have slightly higher $\mathrm{Na}$ contents and small negative Eu anomalies, whereas Mono-Inyo dacites lack such anomalies. Mammoth Mountain (Caldera suite) and Paoha Island (Mono-Inyo suite) low- $\mathrm{SiO}_{2}$ rhyolites have lower $\mathrm{Sr}, \mathrm{P}$, and Ti contents, higher $\mathrm{Zr}$ contents, and larger negative Eu anomalies than their associated dacites. Mono-Inyo rhyolites are more depleted in $\mathrm{Ba}, \mathrm{Ta}$, $\mathrm{Nb}, \mathrm{Ti}$, and REE contents than Caldera rhyolites.

\section{Comparison of the Precaldera and Postcaldera Sequences}

Most major-oxide trends of the precaldera and postcaldera sequences (fig. 13A) are subparallel, but postcaldera lavas have slightly higher $\mathrm{TiO}_{2}, \mathrm{FeO}^{*}$, and $\mathrm{Na}_{2} \mathrm{O}$ contents and lower $\mathrm{MgO}$ and $\mathrm{P}_{2} \mathrm{O}_{5}$ contents. In the precaldera sequence, however, $\mathrm{Al}_{2} \mathrm{O}_{3}$ content increases with increasing $\mathrm{SiO}_{2}$ content, whereas in the postcaldera sequence $\mathrm{Al}_{2} \mathrm{O}_{3}$ content decreases with increasing $\mathrm{SiO}_{2}$ content. These differences apparently reflect crystallization of mafic minerals (olivine, pyroxene, amphibole) in the precaldera sequence and of plagioclase in the postcaldera sequence. Many postcaldera trace-elements trends $(\mathrm{Rb}, \mathrm{Th}$, $\mathrm{Ta}, \mathrm{Zr}$, Y, REEs) also depart from precaldera trends (figs. 13B, $13 C$ ), particularly at higher than 60 weight percent $\mathrm{SiO}_{2}$. For some elements (Th, LREEs), postcaldera dacites/trachydacites fall in the same elevated range as precaldera East Sierran dacites.

Except for the Buttresses and Horseshoe Lake flows, postcaldera basalts have higher $\mathrm{Al}_{2} \mathrm{O}_{3}, \mathrm{TiO}_{2}$, and $\mathrm{FeO} *$ contents and lower $\mathrm{MgO}, \mathrm{P}_{2} \mathrm{O}_{5}, \mathrm{Rb}$, and $\mathrm{Ba}$ contents than precaldera basalts (figs. 13A, 13B). Mg numbers for the most mafic postcaldera basalts are lower (53-67) than for precaldera
East Sierran basalts (68-80) and similar to those for Basin and Range basalts (56-67). Most postcaldera basalts have distinctly lower $\mathrm{Ni}$ and $\mathrm{Cr}$ contents than precaldera basalts (fig. 16), but similar Sc contents; the Buttresses and Horseshoe Lake flows, however, have $\mathrm{MgO}, \mathrm{Ni}$, and $\mathrm{Cr}$ contents similar to those of precaldera basalts. The postcaldera sequence has significantly higher $\mathrm{Zr} / \mathrm{Ba}$ ratios $(0.3-0.7)$ than the precaldera sequence (fig. 17) by virtue of its lower Ba contents. On mantle-normalized trace-element diagrams (fig. 18), postcaldera basalts are less enriched in LILEs ( $\mathrm{Rb}, \mathrm{Ba}, \mathrm{K}, \mathrm{Sr}$ ) and less depleted in HFSEs ( $\mathrm{Ta}, \mathrm{Nb}, \mathrm{Ti}$ ) than precaldera basalts and thus show less strongly spiked profiles. A distinctive feature of most Caldera basalts is their lower mantle-normalized $\mathrm{K} / \mathrm{La}$ ratios, owing to their relatively higher LREE and lower K contents. Caldera and Mono-Inyo basalts have significantly lower chondrite-normalized $\mathrm{Ce} / \mathrm{Yb}$ ratios $\left((\mathrm{Ce} / \mathrm{Yb})_{\mathrm{n}}=8-11\right.$ and $6-8$, respectively) than most precaldera basalts $\left((\mathrm{Ce} / \mathrm{Yb})_{\mathrm{n}}=9-20\right)$, and show a progressive decrease in LREE contents over time.

Postcaldera dacites, relative to precaldera dacites, have higher $\mathrm{SiO}_{2}$ contents, approaching low-SiO $\mathrm{S}_{2}$ (70 weight percent $\mathrm{SiO}_{2}$ ) rhyolites, and have higher total alkalis, $\mathrm{Rb}, \mathrm{Ta}$, and $\mathrm{Nb}$ contents and lower $\mathrm{Ba}$ and $\mathrm{Sr}$ contents. One exception is the intracaldera hornblende-plagioclase-phyric dacite dome at the base of Glass Mountain, which for most elements plots in the field of precaldera Basin and Range dacites (figs. 13B, $13 C$ ); like Basin and Range dacites, this dome is particularly depleted in REEs relative to all other postcaldera dacites (fig. $13 C$ ), supporting the inference that it represents a postcaldera vestige of precaldera Basin and Range dacitic magma.

The overall impression gained from these chemical relations is that the postcaldera sequence was derived from a different source than the precaldera sequence and that the two sequences evolved by different magmatic processes.

\section{$\mathrm{Sr}$, Nd, and $\mathrm{Pb}$ Isotopes}

\section{Sampling}

The Long Valley Volcanic Field has not been studied comprehensively for $\mathrm{Sr}, \mathrm{Nd}$, and $\mathrm{Pb}$ isotopes; the precaldera sequence is particularly sparsely sampled, especially for $\mathrm{Nd}$. Van Kooten (1981) reported Sr- and Pb-isotopic data for ultrapotassic Central Sierran lavas. R.W. Kistler (unpub. data, 1987) measured the Sr-isotopic ratios of 19 representative lavas but included only two basalts each from the precaldera and postcaldera sequences. Chaudet (1986) analyzed six basalts and three dacites from the East Sierran suite for $\mathrm{Sr}$ isotopes, and Ormerod (1988) and Ormerod and others (1988) analyzed a few basalts for $\mathrm{Sr}$ and $\mathrm{Nd}$ isotopes. Cousens (1996) measured $\mathrm{Sr}, \mathrm{Nd}$, and $\mathrm{Pb}$ isotopes for 39 postcaldera mafic lavas, including 12 from corehole Inyo-4. A few additional $\mathrm{Sr}$ - and Nd-isotopic measurements on Mono-Inyo lavas were made by Sampson and Cameron (1987), Kelleher and Cameron (1990), and Christensen and DePaolo (1993). All 

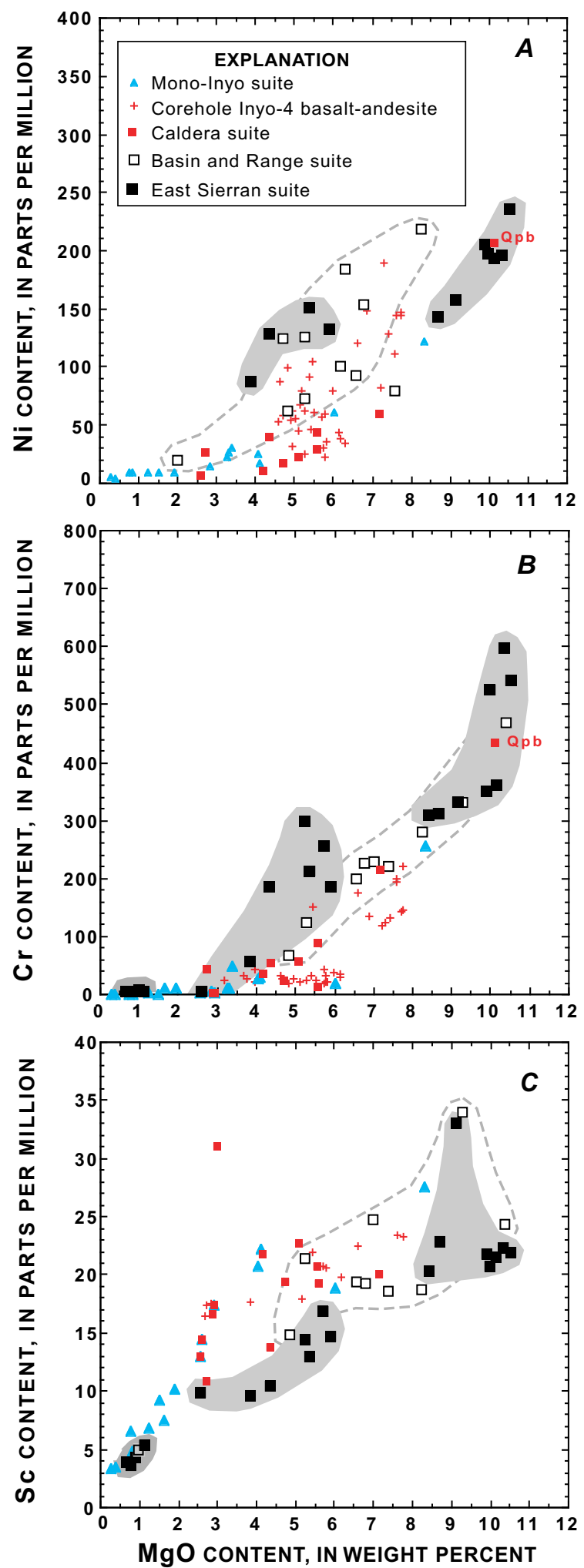

Figure 16. $\mathrm{Ni}$, $\mathrm{Cr}$, and $\mathrm{Sc}$ versus $\mathrm{MgO}$ contents of precaldera and postcaldera sequences. Note low $\mathrm{Ni}$ and $\mathrm{Cr}$ contents and high Sc contents of postcaldera suites relative to precaldera suites, suggesting preeruption settling of olivine and late crystallization of augite in postcaldera suites. Note also exceptionally high $\mathrm{Ni}$ and $\mathrm{Cr}$ contents of postcaldera parental basalt of Horseshoe Lake (unit Qpb, figs. 4-6). available $\mathrm{Sr}-$, $\mathrm{Nd}-$, and $\mathrm{Pb}$-isotopic data are listed in table 6. The locations of $\mathrm{Sr}$-isotopic samples and their respective isotopic ratios are mapped in figure $19 .{ }^{87} \mathrm{Sr} /{ }^{86} \mathrm{Sr},{ }^{143} \mathrm{Nd} /{ }^{144} \mathrm{Nd},{ }^{206} \mathrm{~Pb} /$ ${ }^{204} \mathrm{~Pb},{ }^{207} \mathrm{~Pb} /{ }^{204} \mathrm{~Pb}$, and ${ }^{208} \mathrm{~Pb} /{ }^{204} \mathrm{~Pb}$ ratios are plotted in figures 20 and 21. Because of the complexity of regional relations and the paucity of isotopic data for the Long Valley Volcanic Field, the generalizations presented below are tentative and subject to revision as more data become available.

\section{Regional Relations: $\mathrm{Sr}_{\mathrm{i}}=\mathbf{0 . 7 0 6}$ Isopleth}

The interpretation of isotopic data from the Long Valley Volcanic Field is complicated by the fact that in its vicinity, the $\mathrm{Sr}_{\mathrm{i}}=0.706$ isopleth of Kistler and Peterman (1973), and the west edge of North American crystalline basement inferred to coincide with it, are offset by major northwest-trending Late Cretaceous-early Tertiary transcurrent faults (IBB2, IBB3; inset, fig. 19A; Kistler, 1993). These faults coincide with strands of the present East Sierran frontal fault zone, which passes through the middle of Long Valley Caldera. The position and trend of this fault zone, which presently displays mainly Pliocene-Holocene dip-slip offset, are evidently controlled by these older transcurrent structures. The southwest-trending segment of the $\mathrm{Sr}_{\mathrm{i}}=0.706$ isopleth in the middle of the caldera (fig. 19 ) is displaced along the East Sierran frontal fault zone (IBB3; inset, fig. 19A) $175 \mathrm{~km}$ northwestward to the vicinity of Lake Tahoe. The westward continuation of the displaced isopleth arcs southwestward from Lake Tahoe through the western Sierran foothills and passes $30 \mathrm{~km}$ to the west of the caldera, just west of the ultrapotassic Central Sierran lavas at the southwest edge of the volcanic field, where it locally coincides with the contact between North American crystalline basement on the east and Mesozoic accreted terranes on the west. By inference, the northeast sector of the volcanic field is underlain by Paleozoic eugeosynclinal rocks, and the northwest, southwest, and southeast sectors by Paleozoic miogeosynclinal rocks and

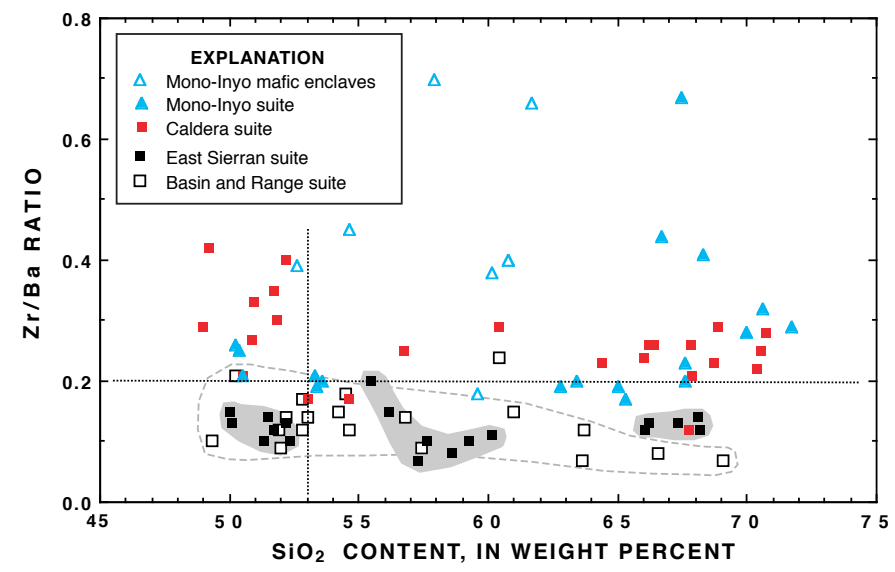

Figure 17. $\mathrm{Zr} / \mathrm{Ba}$ ratio versus $\mathrm{SiO}_{2}$ content of precaldera and postcaldera sequences. Note high ( $>0.2) \mathrm{Zr} / \mathrm{Ba}$ ratios of postcaldera lavas and, particularly, of Mono-Inyo mafic magmatic enclaves, suggesting possible involvement of mafic lower crust. 

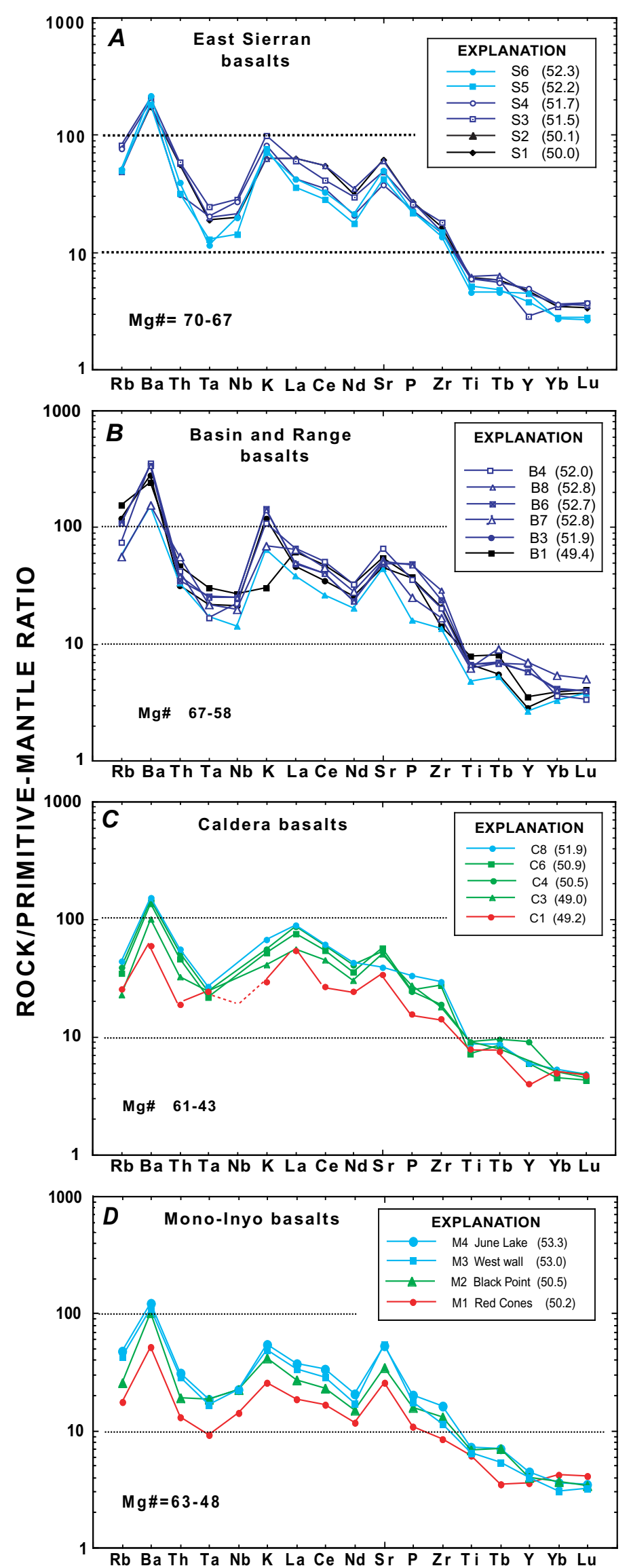

Precambrian North American crystalline basement (Kistler and Peterman, 1973). Kistler and Peterman's (1973) $\mathrm{Sr}_{\mathrm{i}}=0.706$ isopleth is defined by the $\mathrm{Sr}$-isotopic ratios of midcrustal to upper-crustal Mesozoic plutonic rocks, which they inferred to be partly derived from mafic sources in the lithospheric mantle (Kistler and Peterman, 1978), citing as evidence that associated Mesozoic mafic volcanic rocks have isotopic ratios and distributions similar to those of the plutons. If Long Valley lavas are derived from this same lithospheric-mantle source, their Sr-isotopic ratios should mimic those of coextensive Mesozoic plutons and volcanic rocks and show similar changes across the $\mathrm{Sr}_{\mathrm{i}}=0.706$ isopleth, as appears to be so for most precaldera basalts but not for postcaldera basalts.

\section{Long Valley General Isotopic Relations}

Sr-isotopic ratios for most precaldera basalts conform approximately to the $\mathrm{Sr}_{\mathrm{i}}=0.706$ isopleth (fig. 19A) as defined by Kistler and Peterman (1973), although Sr-isotopic ratios for the Basin and Range suite $\left({ }^{87} \mathrm{Sr} /{ }^{86} \mathrm{Sr}=0.70603-0.70613\right)$ east of the East Sierran frontal fault zone (IBB3; Kistler, 1993) are slightly lower than those for the Central and East Sierran suites $\left({ }^{87} \mathrm{Sr} /{ }^{86} \mathrm{Sr}=0.70618-0.70670\right)$ west of the fault zone. A precaldera basalt north of the caldera and north of the $\mathrm{Sr}_{\mathrm{i}}=0.706$ isopleth has a seemingly anomalously high ratio

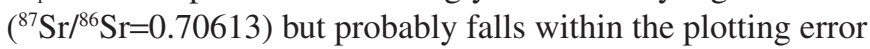
of the isopleth as defined by Kistler and Peterman (1973). The low Sr-isotopic ratios of Central Sierran suite samples

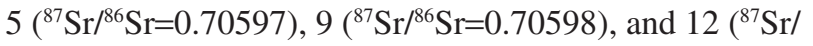
${ }^{86} \mathrm{Sr}=0.70430$ ) (red numbers, fig. 19A) are consistent with an origin, based on chemistry, as OIB melts or crustally contaminated OIB melts from an asthenospheric mantle source.

Most postcaldera basalts (fig. 19B) were erupted from vents south and west of the $\mathrm{Sr}_{\mathrm{i}}=0.706$ isopleth and, like most precaldera basalts, have $\mathrm{Sr}$-isotopic ratios higher than 0.706 , consistent with derivation from a lithosphericmantle source. However, the most mafic postcaldera basalts of both the Caldera and Mono-Inyo suites have Sr-isotopic ratios less than 0.706 , including the oldest Caldera basalts: corehole Inyo-4 groups IV and V $\left({ }^{87} \mathrm{Sr} /{ }^{86} \mathrm{Sr}=0.70516-0.70597\right)$ and the youngest Mono-Inyo basalts at Black Point $\left({ }^{87} \mathrm{Sr} /{ }^{86} \mathrm{Sr}=0.70538-0.70545\right)$ and Red

Figure 18. Variations in primitive-mantle-normalized trace-element profiles of precaldera and postcaldera basalts. $A$, East Sierran basalts. $B$, Basin and Range basalts. $C$, Caldera basalts. $D$, Mono-Inyo basalts. Numbers in explanations refer to samples listed in tables 2 through 5 ; numbers in parentheses are $\mathrm{SiO}_{2}$ contents (in weight percent). Mg\#, magnesium number. Note lower $\mathrm{Rb}, \mathrm{Ba}$, and $\mathrm{K}$ contents of postcaldera basalts (Caldera and Mono-Inyo suites) relative to precaldera basalts in the East Sierran and Basin and Range suites. Note also relatively high La, $\mathrm{Ce}$, and $\mathrm{Nd}$ contents $(\mathrm{K} / \mathrm{La}<1)$ of Caldera primitive basalt $(\mathrm{C} 1$, red) and lower $\mathrm{La}, \mathrm{Ce}$, and $\mathrm{Nd}$ contents (K/La>1) of primitive Mono-Inyo basalt (M1, red). 

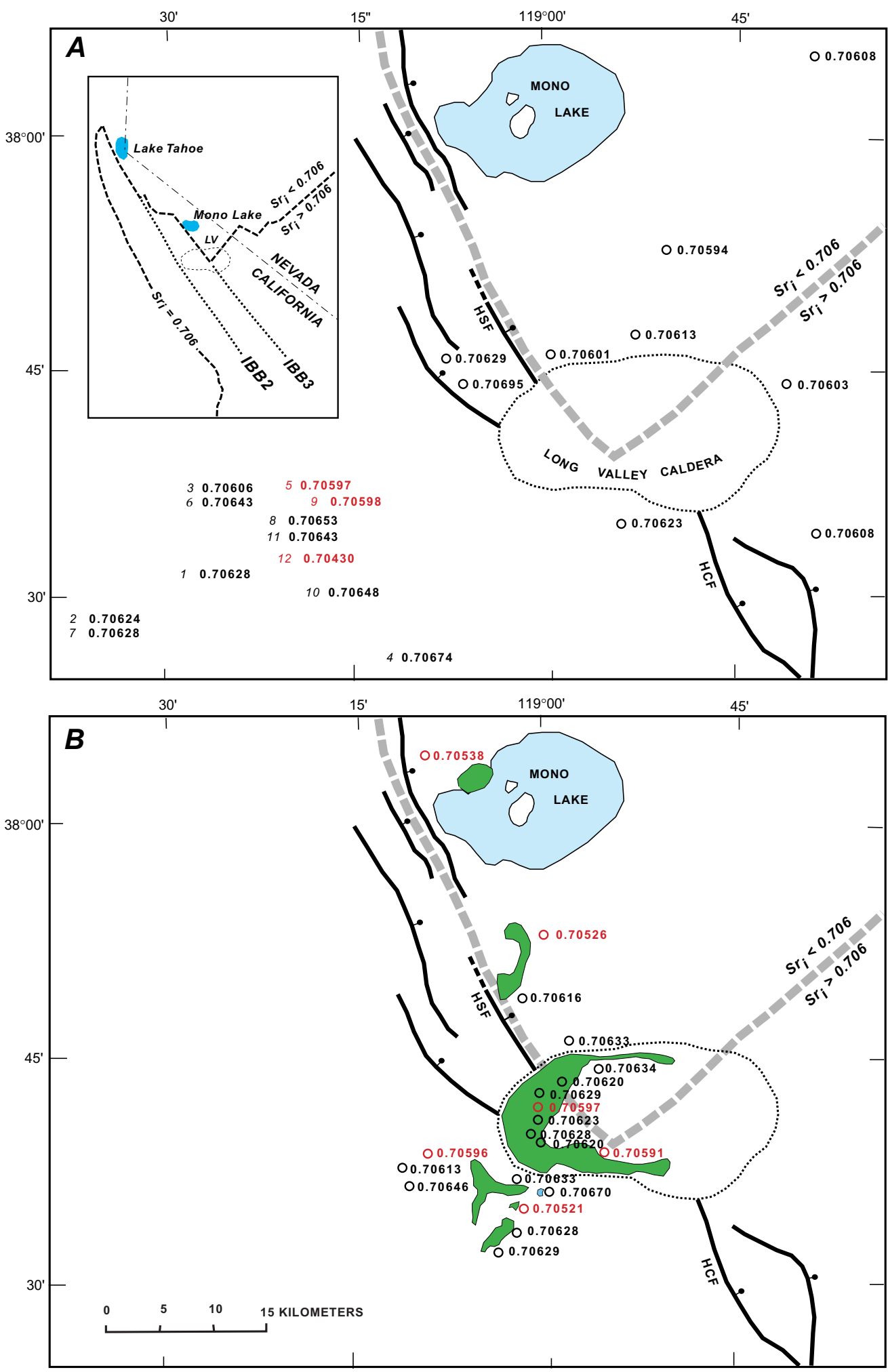

Figure 19. Sketch map of central part of the Long Valley Volcanic Field, Calif., showing location of Long Valley Caldera (dashed outline) and distribution of Sr-isotopic samples of precaldera and postcaldera basalts. $A_{,}{ }^{87} \mathrm{Sr} /{ }^{86} \mathrm{Sr}$ ratio of precaldera basalts. $B,{ }^{87} \mathrm{Sr} r{ }^{86} \mathrm{Sr}$ ratio of postcaldera basalts. Long- and short-dashed lines in inset are $\mathrm{Sr}_{\mathrm{i}}=0.706$ isopleth and faults IBB2 and IBB3, respectively (after Kistler, 1993). Shaded dashed line in figures $19 A$ and $19 B$ is Long Valley segment of $\mathrm{Sr}_{\mathrm{i}}=0.706$ isopleth. Data from table 6. HCF, Hilton Creek Fault; HSF, Hartley Springs Fault. 
Cones $\left({ }^{87} \mathrm{Sr} /{ }^{86} \mathrm{Sr}=0.70516-0.70531\right)$. Such relatively low Sr-isotopic ratios are inconsistent with derivation from a lithospheric-mantle source. These precaldera and postcaldera isotopic relations are discussed further in the following subsections and plotted in figures 20 and 21.

\section{Sr and Nd lsotopes}

Sr- and Nd-isotopic ratios of Long Valley basalts are plotted in figure $20 \mathrm{~A}$, together with the isotopic ranges of local Mesozoic Sierra Nevadan batholithic plutons and the global ranges for OIB and MORB. Sr-isotopic ratios of Long Valley basalts fall in the least radiogenic range for Sierran plutons, and their least radiogenic $\mathrm{Sr}$-isotopic ratios (Mono-Inyo basalts) are skewed toward the ranges for MORB and Basin and Range OIB-like basalts represented by Lunar Craters, Nev., and Amboy and Pisgah Craters, Calif. (fig. 20B.).

As noted above, precaldera Central and East Sierran basalts (fig. 20A), with few exceptions, have higher ${ }^{87} \mathrm{Sr} /{ }^{86} \mathrm{Sr}$ ratios than Basin and Range basalts. The few ${ }^{143} \mathrm{Nd} /{ }^{144} \mathrm{Nd}$ ratios that are available for Central Sierran and East Sierran basalts appear to be lower than for Basin and Range basalts (Nielsen and others, 1991).

Postcaldera basalts, on average, have slightly lower ${ }^{87} \mathrm{Sr} /{ }^{86} \mathrm{Sr}$ and higher ${ }^{143} \mathrm{Nd} /{ }^{144} \mathrm{Nd}$ ratios than precaldera basalts (fig. 20B). In particular, the most mafic ("parental," fig. 20B) Caldera basalts (table 6; corehole Inyo-4 group V breccias, intracaldera south-moat 100-ka Hot Creek basalt flow, and extracaldera Soda Springs [Devils Postpile] basalt) plot in a tight cluster at lower Sr- and slightly higher $\mathrm{Nd}$-isotopic ratios than the majority of Caldera basalts. In contrast, the Buttresses and 100-ka Horseshoe Lake basalts have significantly higher Sr- and lower Nd-isotopic ratios than most Caldera basalts. Individually, however, they have quite distinct $\mathrm{Sr}$ - and $\mathrm{Nd}$ isotopic ratios: the Buttresses flows plot within the range of precaldera basalts, whereas the Horseshoe Lake flows have distinctly higher $\mathrm{Sr}$ - and $\mathrm{Nd}$-isotopic ratios, near the trend for most other postcaldera basalts.

Some Mono-Inyo basalts have the lowest $\mathrm{Sr}$ - and highest Nd-isotopic ratios of the all Long Valley basalts; they also decrease in ${ }^{87} \mathrm{Sr} /{ }^{86} \mathrm{Sr}$ ratio and increase in ${ }^{143} \mathrm{Nd} /{ }^{144} \mathrm{Nd}$ ratio, as well as become more mafic in composition, over time from June Lake (30 ka) through Black Point (13 ka) to Red Cones (5 ka).

Few isotopic data are available for Long Valley dacites. Three precaldera East Sierran dacites (table 6; Chaudet, 1986) have ${ }^{87} \mathrm{Sr} /{ }^{86} \mathrm{Sr}$ ratios (0.70724-0.70949) significantly higher than those of their associated basalts and trachyandesites (0.70618-0.70702). In contrast, the few measured postcaldera dacites have $\mathrm{Sr}$ - and $\mathrm{Nd}$-isotopic ratios similar to those of their associated basalts (table 6; Kelleher and Cameron, 1990; Cousens, 1996).

The contrasting $\mathrm{Sr}$-isotopic ratios of basalts, trachyandesites, and dacites within and between the precaldera and postcaldera sequences are plotted in figure 21. At comparable $\mathrm{SiO}_{2}$ contents, most Central and East Sierran basalts (fig. 21A) have perceptibly higher ${ }^{87} \mathrm{Sr} /{ }^{86} \mathrm{Sr}$ ratios than Basin and Range basalts. Central Sierran OIB-like basalt (sample 12) plots well below the range for all other precaldera basalts. East Sierran dacites have widely scattered, high ${ }^{87} \mathrm{Sr} /{ }^{86} \mathrm{Sr}$ ratios in the same general range as local Mesozoic plutons, whereas Basin and Range dacites, in contrast, have lower ${ }^{87} \mathrm{Sr} /{ }^{86} \mathrm{Sr}$ ratios similar to those of their associated basalts. In the postcaldera sequence (fig. 21B), Caldera basalts and trachyandesites show a perceptible increase in ${ }^{87} \mathrm{Sr} /{ }^{86} \mathrm{Sr}$ ratio with increasing $\mathrm{SiO}_{2}$ content,

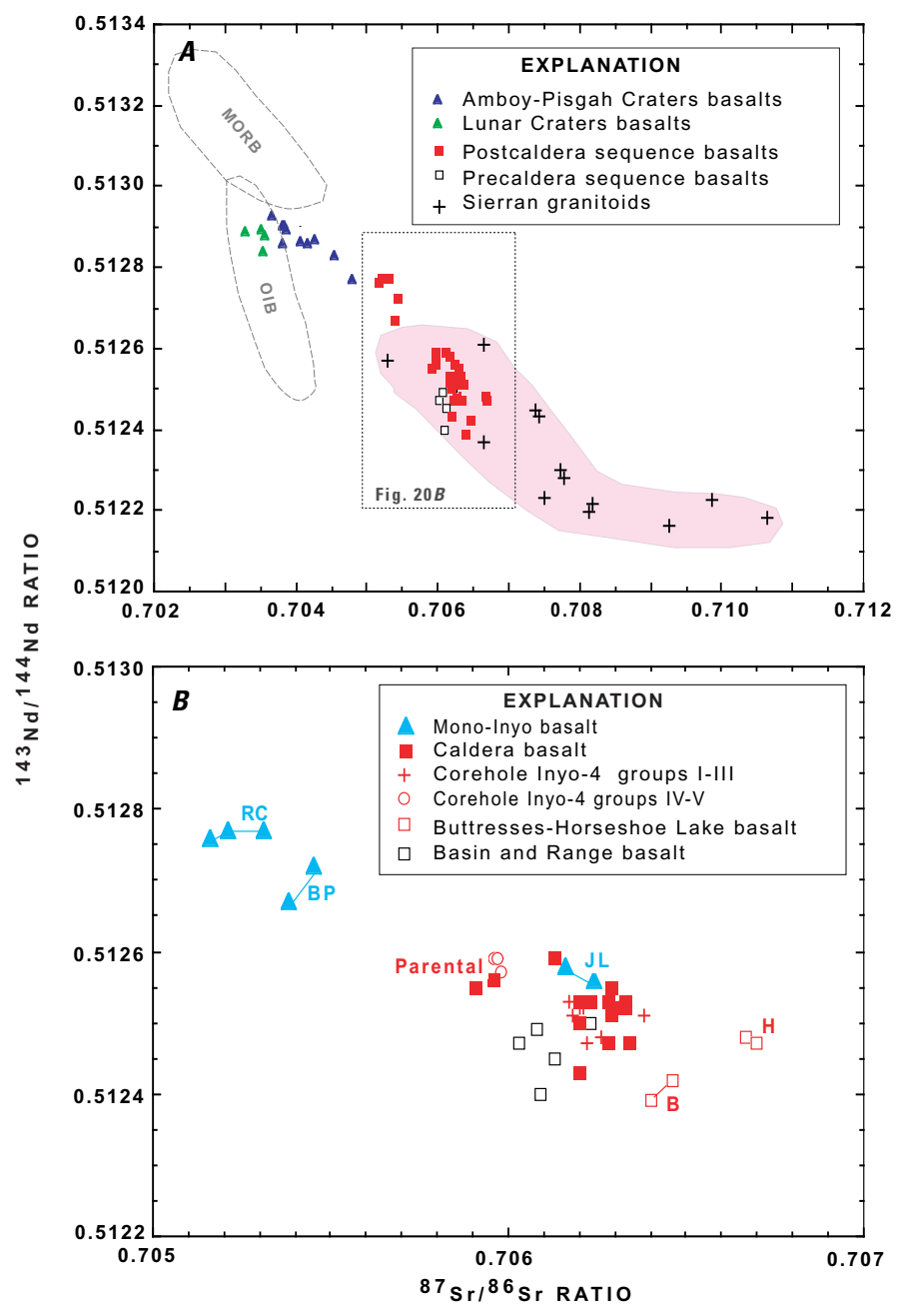

Figure 20. Sr-versus $\mathrm{Nd}$-isotopic ratios for Long Valley basalts. $A$, ${ }^{87} \mathrm{Sr} /{ }^{86} \mathrm{Sr}$ versus ${ }^{143} \mathrm{Nd} /{ }^{144} \mathrm{Nd}$ ratios for Long Valley basalts in comparison with isotopic range of local Sierra Nevada Mesozoic granitoids (Kistler, 1993), as well as general isotopic range of ocean-island basalt (OIB) and midocean-ridge basalt (MORB) (after Menzies, 1989) and isotopic composition of Lunar Craters and Amboy-Pisgah Craters OIB-like basalts (Lum and others, 1989; Glazner and others, 1991) from the Basin and Range Province. $B$, Enlargement of figure $20 A$, showing detailed relations among precaldera and postcaldera basalts. B, Buttresses basalts; BP, Black Point basalt; $H$, Horseshoe Lake basalt; JL, June Lake basalt; RC, Red Cones basalt. Note compositional shift of Caldera parental basalts and Mono-Inyo basalts (BP, RC) toward OIB-like Lunar Craters and Amboy-Pisgah Craters basalts. Three "parental" units are discussed in text. 
consistent with progressive contamination by a more radiogenic component. ${ }^{87} \mathrm{Sr} /{ }^{86} \mathrm{Sr}$ ratios of some Mono-Inyo basalts cluster well below those of Caldera basalts. Caldera dacites have ${ }^{87} \mathrm{Sr} /{ }^{86} \mathrm{Sr}$ ratios only slightly higher than their associated basalts and trachyandesites. Mono-Inyo dacites have ${ }^{87} \mathrm{Sr} /{ }^{86} \mathrm{Sr}$ ratios similar to those of Caldera dacites; however, these ratios are considerably higher than those of their associated basalts, suggesting that the Mono-Inyo dacites are isotopically unrelated to the basalts.

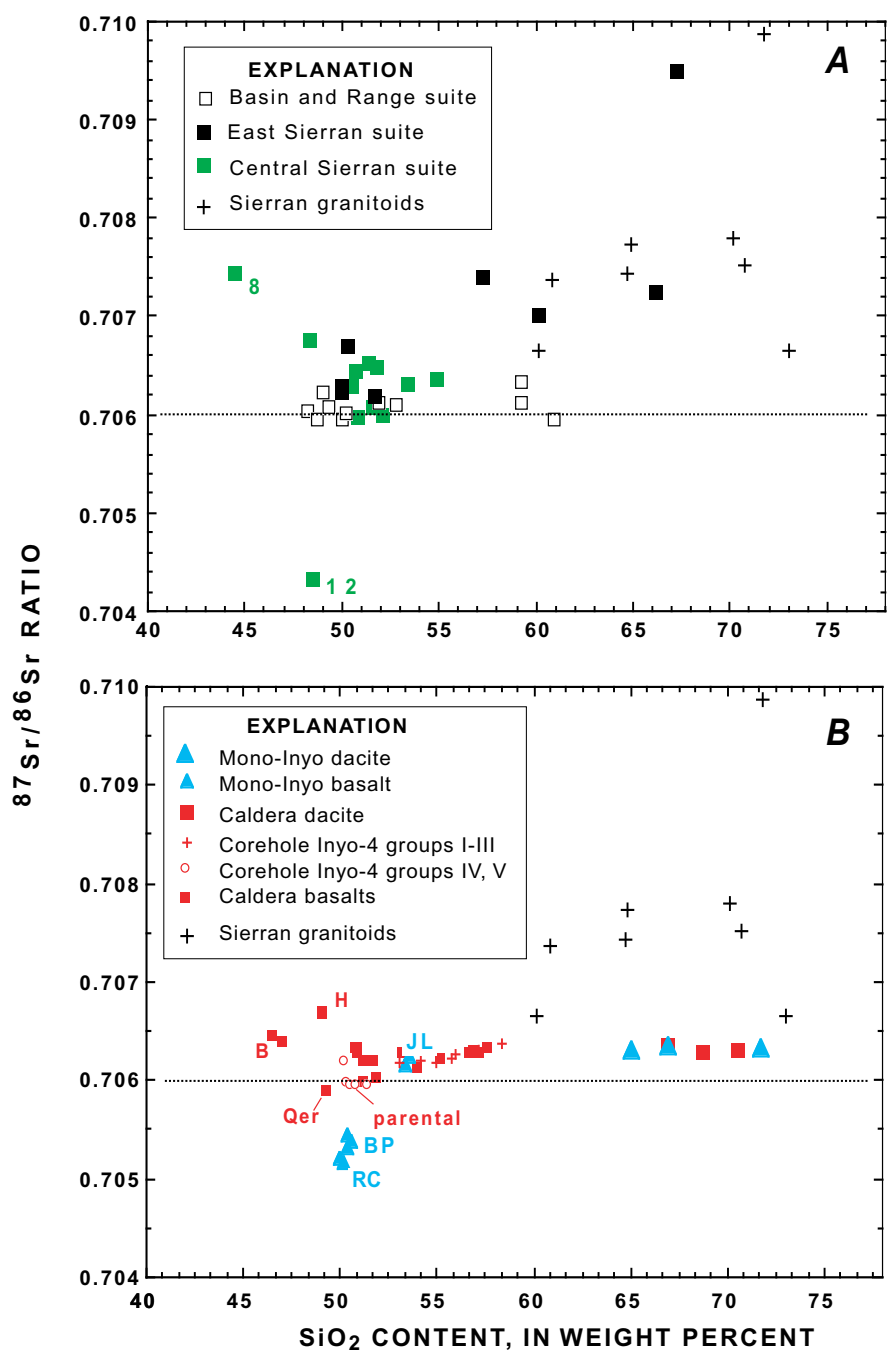

Figure 21. Sr-isotopic ratio versus $\mathrm{SiO}_{2}$ content of Long Valley basalts. Data from table 6. $A$, Precaldera sequence. Note higher ${ }^{87} \mathrm{Sr} /{ }^{86} \mathrm{Sr}$ ratios of the Central and East Sierran suites relative to the Basin and Range suite, as well as much higher and more diverse ${ }^{87} \mathrm{Sr} /{ }^{86} \mathrm{Sr}$ ratios of East Sierran trachyandesite and dacite, similar to Sierra Nevada granitoids. $B$, Postcaldera sequence. Note low ${ }^{87} \mathrm{Sr} /{ }^{86} \mathrm{Sr}$ ratios of Mono-Inyo basalts (BP, RC) relative to Caldera basalts. as well as low ${ }^{87} \mathrm{Sr} /{ }^{86} \mathrm{Sr}$ ratios of postcaldera dacite relative to precaldera dacite (fig. $21 A$ ). Note also gradual increase in isotopic ratios with $\mathrm{SiO}_{2}$ content for Caldera basalttrachyandesite lavas, suggesting contamination by Sierran granitoids or dacites.

\section{$\mathrm{Pb}$ Isotopes}

$\mathrm{Pb}$-isotopic ratios (fig. 22) for postcaldera basalts are generally higher than for precaldera basalts; postcaldera basalts have significantly higher ${ }^{206} \mathrm{~Pb} /{ }^{204} \mathrm{~Pb}$ ratios than precaldera basalts, but overlapping ${ }^{207} \mathrm{~Pb} /{ }^{204} \mathrm{~Pb}$ and ${ }^{208} \mathrm{~Pb} /{ }^{204} \mathrm{~Pb}$ ratios. Precaldera potassic Central Sierran basalts (fig. 22) form four distinct groups, mostly distinguishable on the basis of ${ }^{206} \mathrm{~Pb} /{ }^{204} \mathrm{~Pb}$ ratios: I (sample 8, basanite), II (samples $1-7$ ), III (samples 9-11), and IV (sample 12, alkali olivine basalt, which has a higher ${ }^{206} \mathrm{~Pb} /{ }^{204} \mathrm{~Pb}$ ratio and a lower ${ }^{87} \mathrm{Sr} /{ }^{86} \mathrm{Sr}$ ratio). OIB-like basalt (sample 12; fig. 22), plots within the $\mathrm{Pb}-\mathrm{Sr}$ isotopic range for other OIB-like basalts in the Basin and Range Province, as typified in figure 22 by Coso basalts. The few $\mathrm{Pb}$-isotopic data for precaldera Basin and Range basalts overlap group II (Central Sierran samples 1-7), as do those for the chemically similar postcaldera Buttresses basalts.

Postcaldera basalts as a group are isotopically more radiogenic in $\mathrm{Pb}$ than precaldera basalts, but Caldera and Mono-Inyo basalts are indistinguishable on the basis of $\mathrm{Pb}$ isotopes, as previously noted by Cousens (1996). Note, however, that the Horseshoe Lake basalts plot in the range for postcaldera basalts, as expected, whereas the postcaldera Buttresses basalts plot in the range for precaldera basalts.

\section{Petrogenesis}

\section{General Introduction}

The origin and source of Basin and Range basalts have been controversial and much-debated subjects (Menzies and others, 1983; Fitton and others, 1988; Menzies, 1989; Kempton and others, 1991). Cenozoic Basin and Range basalts typically exhibit two distinctive mantle-normalized trace-element signatures (fig. 23; Fitton and others, 1988; Leeman and Harry, 1993): (1) those with simple, upwardly convex normalized trace-element profiles (fig. 23B) and low Sr- and high $\mathrm{Nd}$-isotopic ratios typical of OIB basalts; and (2) those depleted in HFSEs (Ta, Nb, Ti) and enriched in LILEs ( $\mathrm{Rb}$, $\mathrm{Ba}, \mathrm{K}, \mathrm{Sr}$ ) (fig. 23A), with generally higher Sr- and lower $\mathrm{Nd}$-isotopic ratios, that typically show subduction-zone IABlike normalized trace-element signatures, strongly depleted in $\mathrm{Ta}$ and $\mathrm{Nb}$ and with a distinct decrease in elements less incompatible than $\mathrm{Zr}$. In the Basin and Range Province, basalts with the first signature are sometimes considered to represent subcontinental-asthenospheric-mantle melts, while basalts with the second signature are considered to be derived by partial melting of continental-lithospheric mantle, which has acquired its IAB-like pattern from ancient (Proterozoic) subduction processes, subsequently modified by LILE enrichment (Kempton and others, 1991). The low Ta, Nb, and $\mathrm{Ti}$ contents are believed to be due to retention in such phases as ilmenite and sphene in the subducting slab, and the high LILE contents to be due to metasomatic enrichment 

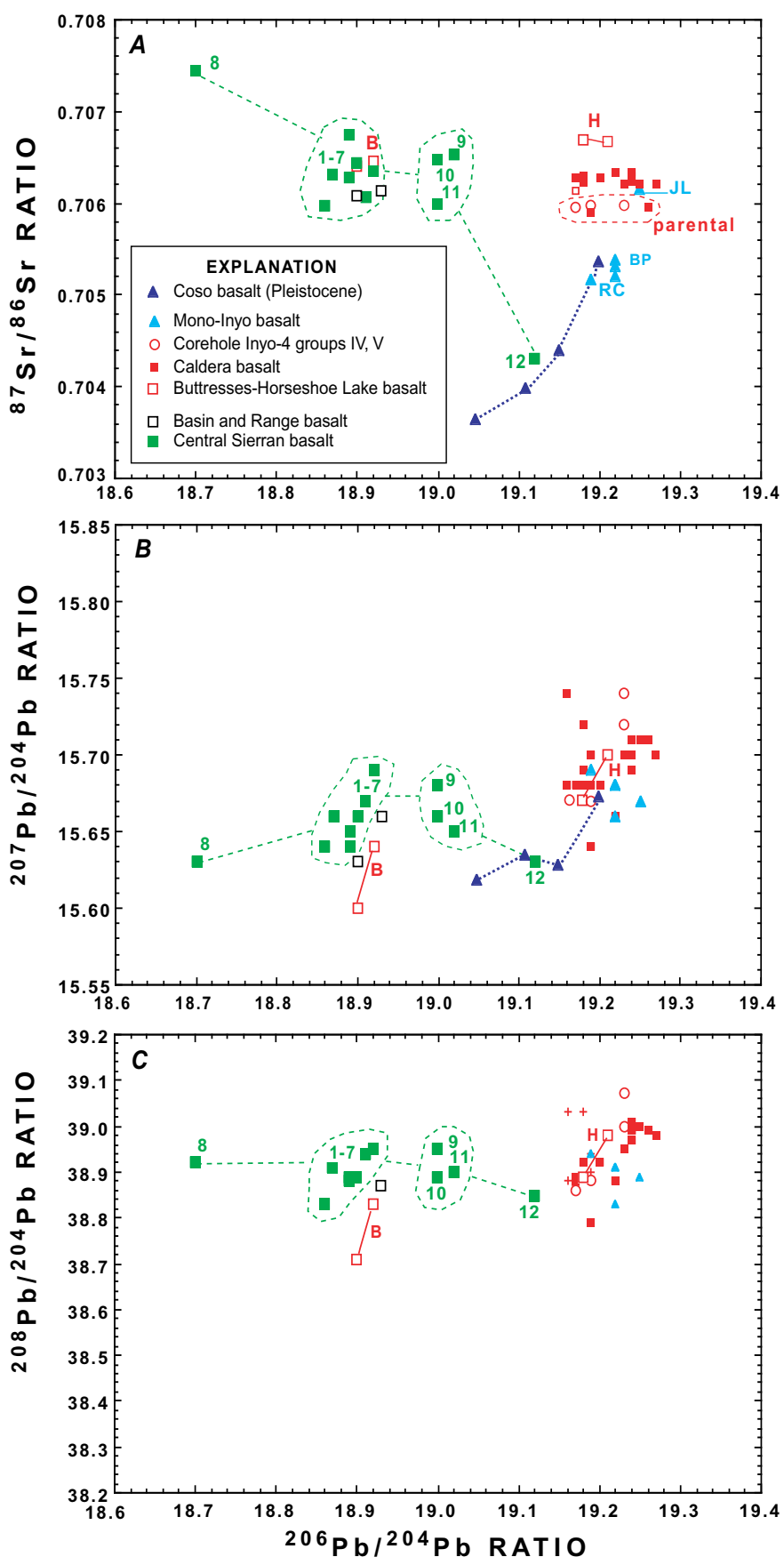

Figure 22. Comparative $\mathrm{Sr}$ - and $\mathrm{Pb}$-isotopic ratios of precaldera and postcaldera basalts. Data from table $6 . A{ }^{87} \mathrm{Sr} /{ }^{86} \mathrm{Sr}$ versus ${ }^{206} \mathrm{~Pb} / 204 \mathrm{~Pb}$ ratios; $B,{ }^{207} \mathrm{~Pb} /{ }^{204} \mathrm{~Pb}$ versus ${ }^{206} \mathrm{~Pb} /{ }^{204} \mathrm{~Pb}$ ratios; $C$, ${ }^{208} \mathrm{~Pb} /$ ${ }^{204} \mathrm{~Pb}$ versus ${ }^{206} \mathrm{~Pb} /{ }^{204} \mathrm{~Pb}$ ratios. $\mathrm{B}$, Buttresses basalt; $\mathrm{BP}$, Black Point basalt; H, Horseshoe Lake basalt; JL, June Lake basalt; RC, Red Cones basalt. "Parental," Caldera parental basalts. Dashed green lines enclose and connect precaldera Central Sierran basalts; dashed red line encloses Caldera parental basalts; dotted blue connects Coso basalts. Note similar isotopic ratios of sample 12 (OIB-like alkali olivine basalt) and Coso basalt (figs. 22A, 22B). Note that in spite of similarity in age and chemical and mineralogic composition, Buttresses basalt plots with precaldera basalts, whereas Horseshoe Lake basalt plots with postcaldera basalts. by hydrous fluids released from the slab (Fitton and others, 1988; Saunders and others, 1988). Although some workers (Thompson and others, 1983, 1984; Wenrich and others, $1995)$ attribute the IAB-like signature of continental basalts to contamination of asthenospheric-mantle melts by crustal rocks, most workers (Fitton and others 1988, 1991; Lum and others, 1989; Kempton and others, 1991; Ormerod and others, 1991; Bradshaw and others, 1993; Leeman and Harry, 1993; Asmerom and others, 1994; Farmer and others, 1995; Turner and Hawkesworth, 1995; Reid and Ramos, 1996; Yogodzinski and others, 1996) consider crustal contamination to be of minor importance in the province, although examples of crustal contamination are common (Bacon and Metz, 1984; Glazner and others, 1991; Glazner and Farmer, 1992).

Kempton and others (1991) reviewed the arguments against significant crustal contamination in basin and Range IAB-like basalts, noting that (1) chemical modeling by mixing of asthenospheric mantle (OIB) and upper-crustal end members requires incorporation of 150 to 400 percent crustal component, producing model basaltic compositions with unrealistically high $\mathrm{SiO}_{2}$ contents; (2) modeling of Sr-, Nd-, and $\mathrm{Pb}$-isotopic compositions also yields basalts with unrealistically high $\mathrm{SiO}_{2}$ contents; and (3) $\mathrm{Sm} / \mathrm{Nd}$ - and $\mathrm{Pb}$-isotopic model ages indicate a source with an age in the range 1.5-2.0 b.y., similar to that of the lithosphere beneath most of the Western United States. Additionally, Mukasa and Wilshire (1997) analyzed undisputed lithospheric-mantle xenoliths in Mojave Desert basalts, showing that they have typical IABlike signatures depleted in $\mathrm{Nb}$, Ta, and Ti. Also, Ormerod and others (1991) argued that the depleted-Nb-Ta signatures of Late Cenozoic Big Pine basalts, considered to be partial melts of lithospheric-mantle spinel peridotites, reflect low source abundances rather than mineralogic effects produced during Cenozoic partial melting.

Spatial and temporal relations of OIB- and enriched IAB-like Cenozoic lavas in the Basin and Range Province also indirectly support their respective asthenospheric- and lithospheric-mantle sources. In several volcanic fields-for example, Lunar Craters, Nev. (Lum and others, 1989), the Colorado River Trough, Nev.-Ariz. (Bradshaw and others, 1993; Feuerbach and others, 1993), and the Coso Volcanic Field (Bacon and Metz, 1984; Novak and Bacon, 1986)_OIB-like basalts typically postdate enriched IAB-like basalts. OIB-like basalts also are generally localized along narrow north-trending zones of extreme extension (>200 percent) where heat flow is high and geophysical and seismic studies indicate a relatively thin lithosphere and a shallow asthenosphere. Leeman and Harry (1993) provide an explanation based on theoretical considerations for these temporal and spatial relations, suggesting that they are the natural consequence of decompression melting in regions of extending and thinning lithosphere. They theorize, on the basis of experimental data, that melting occurs first in the lower lithospheric mantle (mainly in its lowermost 25 $\mathrm{km}$ ) and then in the subjacent asthenosphere when it has risen above $80-\mathrm{km}$ depth because of lithospheric thinning. Thus, 
Table 5. Chemical analyses of lavas of the Mono-Inyo suite.

[Major-element-oxide contents in weight percent; minor-element contents in parts per million. Mg\#, magnesium number, $\mathrm{Mg} /(\mathrm{Mg}+\mathrm{Fe}) ; \mathrm{SiO}_{2}{ }^{*}, \mathrm{SiO}{ }_{2}$ content recalculated to 100 -percent volatile free; $\mathrm{LOI}$, loss on ignition at $925^{\circ} \mathrm{C}$; n.a., not analyzed]

\begin{tabular}{|c|c|c|c|c|c|c|c|c|c|c|c|c|c|c|c|c|c|c|c|c|c|}
\hline \multirow{3}{*}{ 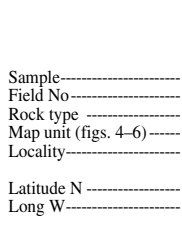 } & \multicolumn{5}{|c|}{ Mono-Inyo basalts } & \multicolumn{4}{|c|}{ Inyo Domes enclaves } & \multicolumn{4}{|c|}{ Mono Domes enclaves } & \multirow{3}{*}{$\begin{array}{c}\text { M14 } \\
\text { MC74.11 } \\
\text { Dacite } \\
\text { Ord } \\
\text { Dome (12) } \\
37^{\circ} 54.1^{\prime} \\
119^{2} 2.0^{\prime}\end{array}$} & \multicolumn{7}{|c|}{ Mono Lake lavas } \\
\hline & \multirow{2}{*}{$\begin{array}{c}\text { M1 } \\
\text { DP1-2 } \\
\text { Basalt } \\
\text { Oyb } \\
\text { Red Cones } \\
37025.4^{\prime} \\
119^{\circ} 35^{\prime}\end{array}$} & \multirow{2}{*}{ 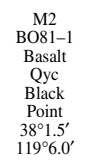 } & \multirow{2}{*}{$\begin{array}{c}\text { M3 } \\
\text { DP86-3 } \\
\text { Basalt } \\
\text { Oa } \\
\text { W. wall } \\
37^{\circ} 41.9^{\prime} \\
119^{9} 33^{\prime}\end{array}$} & \multirow{2}{*}{$\begin{array}{c}\text { M4 } \\
\text { MC74-8 } \\
\text { Basalt } \\
\text { Qa } \\
\text { June N. } \\
37^{2} 49.7^{\prime} \\
119^{\circ} 41^{\prime}\end{array}$} & \multirow{2}{*}{$\begin{array}{c}\text { M5 } \\
\text { MC74-7 } \\
\text { Basalt } \\
\text { Oa } \\
\text { June NE. } \\
37553.1^{\prime} \\
119^{\circ} .4^{\prime}\end{array}$} & \multirow{2}{*}{$\begin{array}{l}\text { M6 } \\
\text { IVGC-1 } \\
\text { Andesite } \\
\text { Enclave } \\
\text { Glass } \\
\text { Creek } \\
377^{2} 4.8^{\prime} \\
119^{\prime} 1.3^{\prime}\end{array}$} & \multirow{2}{*}{$\begin{array}{l}\text { M7 } \\
\text { 'LV87-1 } \\
\text { Andesite } \\
\text { Enclave } \\
\text { Deadman } \\
\text { Creek } \\
\text { 37042.8 } \\
119^{\circ} 1.1^{\prime}\end{array}$} & \multirow{2}{*}{$\begin{array}{l}\text { M8 } \\
\text { '83083-1 } \\
\text { Andesite } \\
\text { Enclave } \\
\text { Deadman } \\
\text { Creak } \\
37^{7022.28} \\
119^{\circ} 1.1^{\prime}\end{array}$} & \multirow{2}{*}{$\begin{array}{l}\text { M9 } \\
\text { DP87-6 } \\
\text { Andesite } \\
\text { Enclave } \\
\text { Deadman } \\
\text { Creek } \\
37^{2} 42.8^{\prime} \\
119^{\circ} .1^{\prime}\end{array}$} & 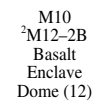 & $\begin{array}{l}\text { M11 } \\
{ }^{2} \mathrm{M} 11-1 \mathrm{~B} \\
\text { Andesite } \\
\text { Enclave } \\
\text { Dome (12) }\end{array}$ & $\begin{array}{c}\mathrm{M} 12 \\
{ }^{2} \mathrm{M1} 1-\mathrm{BB} \\
\text { Andestie } \\
\text { Enclave } \\
\text { Dome (14) }\end{array}$ & $\begin{array}{c}\text { M13 } \\
\text { '2M18-1B } \\
\text { Andesite } \\
\text { Enclave } \\
\text { Dome (18) }\end{array}$ & & \multirow{2}{*}{ 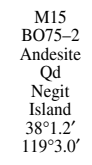 } & \multirow{2}{*}{$\begin{array}{l}\text { M16 } \\
\text { BOT74-4 } \\
\text { Andesite } \\
\text { Od } \\
\text { Paoha } \\
\text { Island } \\
38^{\circ} 0.7^{\prime} \\
119^{\circ} .5^{\prime}\end{array}$} & \multirow{2}{*}{ 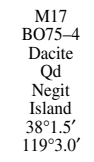 } & \multirow{2}{*}{ 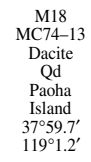 } & \multirow{2}{*}{$\begin{array}{c}\text { M19 } \\
\text { BOT5-5 } \\
\text { Dacite } \\
\text { Od } \\
\text { Volcano } \\
\text { Island } \\
38^{\circ} 1.7^{\prime} \\
119^{2} 2.4^{\prime}\end{array}$} & \multirow{2}{*}{ 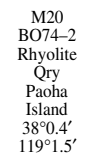 } & \multirow{2}{*}{$\begin{array}{c}\text { M21 } \\
\text { BO7-1 } \\
\text { Rhyolite } \\
\text { Qry } \\
\text { Paoha } \\
\text { Island } \\
38^{\prime} 0.4^{\prime} \\
119^{\circ} 1.5^{\prime}\end{array}$} \\
\hline & & & & & & & & & & $\begin{array}{l}377^{\circ} 54.1^{\prime} \\
119^{\circ} 2.0^{\prime}\end{array}$ & $\begin{array}{l}37^{\circ} 54.1^{\prime} \\
19^{\circ} 2.0^{\prime}\end{array}$ & $\begin{array}{l}37^{\circ} 5334^{\prime} \\
119^{\circ} 0.2^{\prime}\end{array}$ & $\begin{array}{l}37^{\circ} 55.4^{\prime} \\
119^{\circ} 0.4^{\prime}\end{array}$ & & & & & & & & \\
\hline \multicolumn{22}{|c|}{ Major-element oxides } \\
\hline $\mathrm{SiO}_{2}^{*} \ldots$ & 50.20 & 50.54 & 52.99 & 53.29 & 53.40 & 59.61 & 60.14 & 60.74 & 61.10 & 52.60 & 54.60 & 57.90 & 61.70 & 67.49 & 62.81 & 63.45 & 65.28 & 67.60 & 67.64 & 70.03 & 70.60 \\
\hline 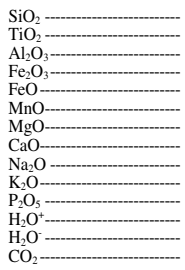 & $\begin{array}{r}50.10 \\
1.33 \\
17.00 \\
2.40 \\
6.60 \\
.14 \\
8.31 \\
9.70 \\
3.24 \\
.76 \\
.23 \\
.11 \\
.11 \\
.01\end{array}$ & $\begin{array}{c}50.10 \\
1.46 \\
18.40 \\
2.14 \\
6.52 \\
.13 \\
5.96 \\
9.07 \\
3.77 \\
1.25 \\
.34 \\
.08 \\
.10 \\
.42\end{array}$ & $\begin{array}{c}52.90 \\
1.39 \\
18.90 \\
2.60 \\
5.24 \\
4.21 \\
4.25 \\
3.57 \\
1.48 \\
.38 \\
.08 \\
.05 \\
.01\end{array}$ & $\begin{array}{c}52.90 \\
1.54 \\
18.30 \\
3.11 \\
5.07 \\
4.11 \\
4.07 \\
3.48 \\
1.64 \\
.43 \\
.35 \\
.16 \\
.01\end{array}$ & $\begin{array}{c}53.00 \\
1.57 \\
18.20 \\
2.53 \\
5.63 \\
4.11 \\
4.02 \\
.43 \\
3.65 \\
1.69 \\
.43 \\
.15 \\
.15 \\
.01\end{array}$ & $\begin{array}{c}57.30 \\
.92 \\
17.00 \\
3.06 \\
2.60 \\
.11 \\
2.74 \\
5.73 \\
4.11 \\
2.90 \\
.35 \\
3.37(\mathrm{LOI}) \\
-.02\end{array}$ & $\begin{array}{c}59.70 \\
.98 \\
16.30 \\
2.79 \\
3.30 \\
.17 \\
3.38 \\
5.31 \\
4.50 \\
2.61 \\
.23 \\
.68(\mathrm{LOI}) \\
-.02\end{array}$ & $\begin{array}{c}58.50 \\
91 \\
15.40 \\
2.90 \\
2.90 \\
.18 \\
3.13 \\
4.99 \\
4.65 \\
2.46 \\
.30 \\
3.08(\mathrm{LOI}) \\
0 \\
0\end{array}$ & $\begin{array}{c}60.80 \\
96 \\
16.60 \\
2.14 \\
3.42 \\
17 \\
3.30 \\
5.30 \\
4.10 \\
2.52 \\
.20 \\
.8 \text { (LOI) } \\
.1 \\
.17\end{array}$ & $\begin{array}{c}53.20 \\
2.11 \\
17.70 \\
10.28 \\
\text { n.. } \\
.10 \\
4.31 \\
7.74 \\
3.84 \\
1.60 \\
.31 \\
.13(\text { LOI) } \\
-. . \\
\text { n.a. }\end{array}$ & $\begin{array}{c}54.56 \\
.94 \\
17.5 \\
9.22 \\
\text { n.a. } \\
1.0 \\
4.47 \\
7.75 \\
3.38 \\
1.66 \\
.38 \\
.87(\text { LOI) } \\
-- \\
\text { n.a. }\end{array}$ & $\begin{array}{c}58.82 \\
1.51 \\
16.15 \\
8.15 \\
\text { n.a. } \\
.10 \\
4.10 \\
5.93 \\
3.90 \\
2.59 \\
.38 \\
.51 \text { (LOI) } \\
-.- \\
\text { n.a. }\end{array}$ & $\begin{array}{c}63.03 \\
1.23 \\
15.63 \\
6.77 \\
\text { n.. } \\
.10 \\
3.08 \\
4.92 \\
4.08 \\
3.02 \\
.28 \\
.14(\mathrm{LOI}) \\
-- \\
\text { n.a. }\end{array}$ & $\begin{array}{r}67.12 \\
.79 \\
14.60 \\
1.40 \\
2.76 \\
1.09 \\
1.64 \\
3.30 \\
4.00 \\
3.60 \\
.15 \\
.36 \\
.12\end{array}$ & $\begin{array}{c}62.50 \\
1.04 \\
16.50 \\
1.69 \\
3.69 \\
.09 \\
1.91 \\
4.17 \\
4.34 \\
3.23 \\
.34 \\
.24 \\
.08 \\
.01\end{array}$ & $\begin{array}{r}62.90 \\
1.101 \\
16.60 \\
1.52 \\
3.40 \\
.09 \\
1.49 \\
3.52 \\
4.63 \\
3.59 \\
.39 \\
.09 \\
.11 \\
.01\end{array}$ & $\begin{array}{l}64.70 \\
16.76 \\
16.50 \\
1.59 \\
. .00 \\
1.27 \\
3.27 \\
4.49 \\
3.52 \\
.28 \\
.16 \\
.12 \\
.01\end{array}$ & $\begin{array}{r}67.10 \\
.57 \\
16.10 \\
1.11 \\
2.09 \\
.07 \\
.75 \\
2.00 \\
4.86 \\
4.45 \\
.16 \\
.15 \\
.1 \\
.01\end{array}$ & $\begin{array}{r}67.00 \\
.53 \\
16.10 \\
1.09 \\
2.21 \\
.07 \\
.81 \\
2.41 \\
4.61 \\
4.06 \\
.17 \\
.14 \\
.12 \\
.02\end{array}$ & $\begin{array}{r}69.40 \\
.28 \\
15.60 \\
.74 \\
1.75 \\
.06 \\
.39 \\
1.47 \\
4.49 \\
4.85 \\
.08 \\
.01 \\
.09 \\
.01\end{array}$ & $\begin{array}{r}69.80 \\
.22 \\
15.30 \\
.78 \\
1.53 \\
.06 \\
.28 \\
1.24 \\
4.58 \\
5.02 \\
.06 \\
.28 \\
.12 \\
.01\end{array}$ \\
\hline Total .... & 100.04 & 99.74 & 99.98 & 99.79 & 99.80 & 99.51 & 99.97 & 99.40 & 100.79 & 101.3 & 100.8 & 102.1 & 102.3 & 99.95 & 99.83 & 99.35 & 99.40 & 99.52 & 99.34 & 99.42 & 99.28 \\
\hline Mg\#\#-.... & 63 & 50 & 50 & 48 & 48 & 48 & 71 & 68 & 53 & 45 & 49 & 50 & 47 & -- & 40 & 36 & 36 & 30 & 32 & 23 & 19 \\
\hline \multicolumn{22}{|c|}{ Minor elements } \\
\hline & $\begin{array}{l}364 \\
41.5 \\
257 \\
.254\end{array}$ & $\begin{array}{l}698 \\
35.1 \\
19.9 \\
.201\end{array}$ & $\begin{array}{c}773 \\
28 \\
36.8\end{array}$ & $\begin{array}{l}853 \\
27.6 \\
29.4 \\
.577\end{array}$ & $\begin{array}{l}829 \\
26.3 \\
26.9 \\
.561\end{array}$ & $\begin{array}{c}937 \\
\overline{5} .9\end{array}$ & $\begin{array}{c}477 \\
-- \\
49\end{array}$ & $\begin{array}{r}464 \\
12-\end{array}$ & $\begin{array}{c}478 \\
10\end{array}$ & $\begin{array}{r}444 \\
-- \\
--\end{array}$ & $\begin{array}{c}352 \\
-- \\
--\end{array}$ & $\begin{array}{r}303 \\
-- \\
--\end{array}$ & $\begin{array}{c}298 \\
-- \\
--\end{array}$ & $\begin{array}{c}303 \\
10.9 \\
9.8 \\
3.3\end{array}$ & $\begin{array}{r}1,250 \\
11.9 \\
9.61 \\
1.58\end{array}$ & $\begin{array}{r}1,390 \\
6.76 \\
.75 \\
1.99\end{array}$ & $\begin{array}{c}1,440 \\
7.18 \\
1.4 \\
1.79\end{array}$ & $\begin{array}{c}1,560 \\
2.06 \\
1.2 \\
2.37\end{array}$ & $\begin{array}{r}1,360 \\
3.97 \\
7 \\
2.07\end{array}$ & $\begin{array}{r}1,120 \\
1.48 \\
2.22 \\
2.46\end{array}$ & $\begin{array}{c}1,020 \\
1.01 \\
3.35 \\
2.62\end{array}$ \\
\hline & 2.83 & --- & --- & -3.78 & -3.74 & 8.5 & 9.5 & 15 & 12 & -- & -- & -- & -- & $\begin{array}{l}12 \\
3.7\end{array}$ & --- & -7. & 637 & $\overline{909}$ & 6.99 & . & $8 .-2$ \\
\hline & $\begin{array}{l}10 \\
122\end{array}$ & $\begin{array}{l}16 \\
61\end{array}$ & 16 & $\begin{array}{l}16 \\
168\end{array}$ & $\begin{array}{l}12 \\
252\end{array}$ & $\begin{array}{l}26 \\
14\end{array}$ & ${ }_{31}^{29-}$ & 27 & 13 & 19 & 18 & 22 & 21 & -- & 16 & $\begin{array}{l}20 \\
90.03\end{array}$ & 14 & $\begin{array}{l}20 \\
962\end{array}$ & 14 & 16 & $\begin{array}{l}8.94 \\
16 \\
491\end{array}$ \\
\hline 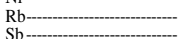 & 11 & ${ }_{16}^{16}$ & 27.2 & $\begin{array}{l}29.7 \\
295\end{array}$ & $\begin{array}{l}30.5 \\
30.28\end{array}$ & ${ }_{89}$ & 80 & 77 & 69 & 35 & 45 & 71 & 87 & 117 & $\begin{array}{l}99.9 \\
69.5\end{array}$ & $\begin{array}{l}90.73 \\
90.737\end{array}$ & $\begin{array}{l}79.9 \\
79.9\end{array}$ & $\begin{array}{l}111.02 \\
114_{44}\end{array}$ & $\begin{array}{l}9.35 \\
92.4\end{array}$ & $\begin{array}{l}1.48 \\
1066\end{array}$ & ${ }^{411} 1_{571}$ \\
\hline & ${ }_{532}^{27.6}$ & $\begin{array}{l}1.1 .5 \\
728\end{array}$ & $\begin{array}{r}20.9 \\
2130\end{array}$ & 22.2 & $\begin{array}{l}20.7 \\
1.040\end{array}$ & -- & -- & -- & -- & -- & -- & 37 & $-0^{--}$ & $\begin{array}{r}.8 \\
7.51\end{array}$ & $\begin{array}{l}.413 \\
52.2\end{array}$ & $\begin{array}{l}.372 \\
9.17\end{array}$ & 6.87 & 6.464 & $\begin{array}{l}.589 \\
4.75\end{array}$ & 3.47 & 17.3 \\
\hline & $\begin{array}{r}532.373 \\
1.09 \\
.324\end{array}$ & $\begin{array}{r}728 \\
.747 \\
1.62 \\
.525\end{array}$ & $\begin{array}{c}1,130 \\
.67 \\
2.39 \\
.865\end{array}$ & $\begin{array}{r}1,100 \\
.755 \\
2.62 \\
.611\end{array}$ & $\begin{array}{r}1,040 \\
.72 \\
2.66 \\
.749\end{array}$ & $\begin{array}{r}873 \\
-- \\
--\end{array}$ & $\begin{array}{r}483 \\
-- \\
-- \\
--\end{array}$ & $\begin{array}{c}492 \\
-- \\
--\end{array}$ & $\begin{array}{c}422 \\
-- \\
--\end{array}$ & $\begin{array}{r}643 \\
-- \\
--\end{array}$ & $\begin{array}{c}592 \\
-- \\
--\end{array}$ & $\begin{array}{r}374 \\
-- \\
--\end{array}$ & $\begin{array}{c}308 \\
-- \\
-- \\
--\end{array}$ & $\begin{array}{r}230 \\
1.72 \\
11.2 \\
3.62\end{array}$ & $\begin{array}{c}527.953 \\
6.01 \\
1.96\end{array}$ & $\begin{array}{c}586 \\
1.37 \\
8.8 \\
2.8\end{array}$ & $\begin{array}{c}518 \\
.953 \\
6.61 \\
2.18\end{array}$ & $\begin{array}{c}316 \\
1.45 \\
10.8 \\
3.44\end{array}$ & $\begin{array}{c}371 \\
.998 \\
8.16 \\
2.65\end{array}$ & $\begin{array}{c}203 \\
1.22 \\
11.1 \\
3.33\end{array}$ & $\begin{array}{c}176 \\
1.28 \\
12.1 \\
3.48\end{array}$ \\
\hline $\mathrm{Zr}$ & $\begin{array}{c}-7- \\
100 \\
93.2\end{array}$ & $\begin{array}{c}18 \\
101 \\
146\end{array}$ & $\begin{array}{c}18 \\
82 \\
128\end{array}$ & $\begin{array}{l}-20 \\
83.6 \\
179\end{array}$ & $\begin{array}{l}18 \\
79.8 \\
158\end{array}$ & $\begin{array}{r}10 \\
83 \\
167\end{array}$ & $\begin{array}{r}14 \\
100 \\
182\end{array}$ & $\begin{array}{c}-- \\
11 \\
110 \\
187\end{array}$ & $\begin{array}{r}26- \\
106 \\
190\end{array}$ & $\begin{array}{c}-\overline{-} \\
26- \\
171\end{array}$ & $\begin{array}{c}-- \\
159\end{array}$ & $\begin{array}{c}--- \\
212\end{array}$ & $\begin{array}{c}--- \\
30- \\
198\end{array}$ & $\begin{array}{r}120 \\
34 \\
64 \\
202\end{array}$ & $\begin{array}{l}22 \\
81.4 \\
241\end{array}$ & $\begin{array}{l}26 \\
84.6 \\
279\end{array}$ & $\begin{array}{l}22 \\
77.3 \\
248\end{array}$ & $\begin{array}{c}30 \\
71.6 \\
365\end{array}$ & $\begin{array}{c}18 \\
70.1 \\
267\end{array}$ & $\begin{array}{l}22 \\
62.2 \\
319\end{array}$ & $\begin{array}{l}22 \\
60.1 \\
326\end{array}$ \\
\hline $\mathrm{Ce}$ & ${ }_{22}^{12.8}$ & $\begin{array}{l}18.6 \\
403\end{array}$ & $\begin{array}{l}22.8 \\
503\end{array}$ & $\begin{array}{l}25.8 \\
58.8\end{array}$ & $\begin{array}{l}24.9 \\
558\end{array}$ & -- & -- & -- & -- & -- & -- & & $\begin{array}{ll}-- & \\
-\end{array}$ & $\begin{array}{l}23 \\
{ }_{425}\end{array}$ & 31.4 & 41 & 33.4 & 46.4 & 40 & 51.4 & 55.8 \\
\hline & $\begin{array}{l}29 \\
15.6\end{array}$ & $\begin{array}{l}40.3 \\
20\end{array}$ & 23 & $\begin{array}{l}58.8 \\
27.6\end{array}$ & $\begin{array}{l}55.8 \\
22.8\end{array}$ & $=-$ & -- & $=-$ & $=-$ & $=-$ & $=-$ & $\begin{array}{l}60.6 \\
28.8\end{array}$ & -- & $\begin{array}{l}42.5 \\
24\end{array}$ & $\begin{array}{l}68 . \\
28 .\end{array}$ & $\begin{array}{l}88.5 \\
36\end{array}$ & $\begin{array}{l}70.1 \\
28.6\end{array}$ & & $\begin{array}{l}76 \\
27 \\
27\end{array}$ & & $\begin{array}{l}{ }^{104} \\
33.1\end{array}$ \\
\hline & 3.7 & 4.44 & 4.46 & 5.07 & $\begin{array}{l}2.75 \\
4.75 \\
4\end{array}$ & -- & -- & -- & -- & -- & -- & 6.03 & -- & 4.68 & 5.19 & 6.7 & 5.16 & 6.17 & 4.68 & 4.88 & 5.07 \\
\hline & $\begin{array}{l}1.26 \\
3.93\end{array}$ & $\begin{array}{l}1.48 \\
4.37\end{array}$ & $\begin{array}{l}1.46 \\
4.25\end{array}$ & $\begin{array}{l}1.65 \\
5.06\end{array}$ & $\begin{array}{l}1.55 \\
4.66\end{array}$ & $=$ & $=$ & $=-$ & $=-$ & $=-$ & $=-$ & $\begin{array}{l}1.44 \\
5.16\end{array}$ & $=-$ & .78 & $\begin{array}{l}1.46 \\
4.1\end{array}$ & $\begin{array}{l}1.86 \\
5.67\end{array}$ & $\begin{array}{l}1.35 \\
4.48\end{array}$ & $\begin{array}{l}1.58 \\
4.96\end{array}$ & $\begin{array}{l}1.09 \\
3.96\end{array}$ & $\begin{array}{l}.883 \\
4.05\end{array}$ & $\begin{array}{l}.794 \\
4.02\end{array}$ \\
\hline Tm & $\begin{array}{l}.604 \\
319\end{array}$ & .617 & .579 & .648 & .64 & -- & $=-$ & -- & -- & -- & -- & -- & -- & .71 & .657 & .85 & $\begin{array}{l}.637 \\
.632\end{array}$ & .772 & .567 & $\begin{array}{l}.561 \\
324\end{array}$ & $\begin{array}{r}.572 \\
.532\end{array}$ \\
\hline 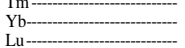 & $\begin{array}{l}.319 \\
2.04 \\
.299\end{array}$ & $\begin{array}{l}.303 \\
1.78 \\
.251\end{array}$ & $\begin{array}{l}.241 \\
1.51 \\
.236\end{array}$ & $\begin{array}{l}.301 \\
1.77 \\
254\end{array}$ & $\begin{array}{l}-.67 \\
1.639\end{array}$ & $\begin{array}{l}-- \\
--\end{array}$ & $\begin{array}{l}-- \\
-\overline{-}\end{array}$ & $\begin{array}{l}-- \\
--\end{array}$ & $\begin{array}{l}-- \\
--\end{array}$ & $=-$ & $\begin{array}{l}-- \\
--\end{array}$ & 2.79 & -- & 2.5 & $\begin{array}{l}.6 .88 \\
1.87 \\
.72\end{array}$ & $\begin{array}{r}.351 \\
2.35\end{array}$ & $\begin{array}{l}.352 \\
1.81 \\
.26\end{array}$ & $\begin{array}{l}.4 .45 \\
2.43\end{array}$ & $\begin{array}{l}.302 \\
1.83 \\
7\end{array}$ & $\begin{array}{l}3.24 \\
2.02\end{array}$ & $\begin{array}{r}.3 .138 \\
2.13\end{array}$ \\
\hline & & & .236 & .254 & .239 & & -- & & & & & & & & & & & & & & \\
\hline
\end{tabular}

'Data from Varga and others (1990),
'Data from Kelleher and Cameron (1991). 
Table 6. Sr-, $\mathrm{Nd}$-, and $\mathrm{Pb}$-isotopic ratios for rock samples from the Long Valley Volcanic Field, Calif.

[References: 1, R.W. Kistler and R.A. Bailey, (unpub. data, 1978); 2, Ormerod (1988); 3, Kelleher and Cameron (1990); 4, Chaudet (1986); 5, Christensen and DePaolo (1993); 6, Cousens (1996); 7, Van Kooten (1981); 8, Kistler (1993). Do., ditto]

\begin{tabular}{|c|c|c|c|c|c|c|c|c|c|c|}
\hline Sample & Reference & Rock type & Locality & $\begin{array}{l}\text { Age } \\
\text { (Ma) }\end{array}$ & $\begin{array}{c}\mathrm{SiO}_{2} \\
\text { (wt pct) }\end{array}$ & $\begin{array}{c}{ }^{87} \mathrm{Sr} r{ }^{86} \mathrm{Sr} \\
\text { ratio }\end{array}$ & $\begin{array}{c}{ }^{143} \mathrm{Nd} /{ }^{144} \mathrm{Nd} \\
\text { ratio }\end{array}$ & $\begin{array}{c}{ }^{206} \mathrm{~Pb} / /^{204} \mathrm{~Pb} \\
\text { ratio }\end{array}$ & $\begin{array}{c}{ }^{207} \mathrm{~Pb} / 204 \mathrm{~Pb} \\
\text { ratio }\end{array}$ & $\begin{array}{c}{ }^{208} \mathrm{~Pb} /{ }^{204} \mathrm{~Pb} \\
\text { ratio }\end{array}$ \\
\hline
\end{tabular}

\section{PRECALDERA SEQUENCE}

\begin{tabular}{|c|c|c|c|c|c|c|c|c|c|}
\hline \multicolumn{10}{|c|}{ Central Sierran suite } \\
\hline 8 & 7 & 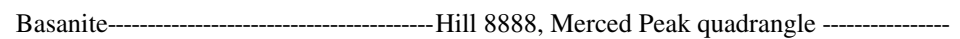 & -- & 44.45 & 0.70744 & -- & 18.704 & 15.663 & 38.921 \\
\hline 4 & 7 & Phonotephrite - & -- & 48.35 & .70675 & -- & 18.891 & 15.649 & 38.890 \\
\hline 12 & 7 & Alkali-olivine basalt-- & -- & 48.52 & .70431 & -- & 19.117 & 15.626 & 38.847 \\
\hline 7 & 7 & Mugearite --Near BM 4980, Bass Lake quadrangle-_- & -- & 50.47 & .70628 & -- & 18.889 & 15.640 & 38.877 \\
\hline 6 & 7 & do-_-Near hill 9841, Merced Peak quadrangle-- & -- & 50.75 & .70644 & -- & 18.896 & 15.655 & 38.890 \\
\hline 5 & 7 & Phonotephrite -- & -- & 50.82 & .70598 & -- & 18.862 & 15.640 & 38.833 \\
\hline 11 & 7 & Hawaiite ---_-_--Near hill 8888, Merced Peak quadrangle--_- & -- & 51.44 & .70653 & -- & 19.018 & 15.648 & 38.897 \\
\hline 3 & 7 & 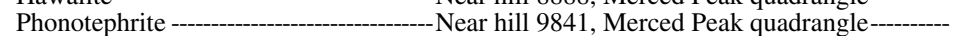 & 3.59 & 51.59 & .70607 & -- & 18.914 & 15.672 & 38.937 \\
\hline 10 & 7 & Mugearite -- & -- & 51.77 & .70648 & -- & 19.002 & 15.660 & 38.889 \\
\hline 9 & 7 & do- Cora Lake, Merced Peak quadrangle - & -- & 52.15 & .70599 & -- & 19.002 & 15.681 & 38.949 \\
\hline 1 & 7 & Tephriphonolite --_- Near hill 8675, Merced Peak quadrangle--_-_-_- & 3.58 & 53.39 & .70631 & -- & 18.873 & 15.663 & 38.913 \\
\hline 2 & 7 & 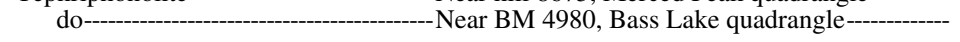 & 3.45 & 54.91 & .70635 & -- & 18.916 & 15.686 & 38.950 \\
\hline \multicolumn{10}{|c|}{ East Sierran suite } \\
\hline cDP83-85 & 4 & Basalt-_- & 3.1 & 50.05 & 0.70622 & -- & -- & -- & -- \\
\hline cDP83-90 & 4 & do--10 & 3.1 & 50.07 & .70629 & -- & -- & -- & -- \\
\hline cDP83-100 & 4 & do-- & 3.1 & 51.69 & .70618 & -- & -- & -- & -- \\
\hline cDP83-94 [93] & 4 & do-10 & 3.1 & -- & .70670 & -- & -- & -- & -- \\
\hline cDP83-68 & 4 & Andesite & 3.1 & 60.17 & .70702 & -- & -- & -- & -- \\
\hline DP78-34 & 4 & Mafic enclave in sample DP78-33---San Joaquin Mountain & 3.0 & 57.28 & .70739 & -- & -- & -- & -- \\
\hline DP78-33 & 4 & Dacite - & 3.0 & 66.24 & .70724 & -- & -- & -- & -- \\
\hline DP78-35 & 4 & Dacite, South Dome-1-San Joaquin Ridge & 3.0 & 67.32 & .70949 & -- & -- & -- & -- \\
\hline cDP83-81 & 4 & Dacite, East Dome-1- & 3.0 & -- & .70732 & -- & -- & -- & -- \\
\hline \multicolumn{10}{|c|}{ Basin and Range suite } \\
\hline CT $72-1$ & 1 & 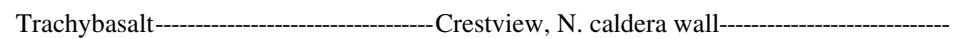 & 3.50 & 50.20 & 0.70601 & -- & - - & -- & -_ \\
\hline AOB-1 & 5 & Basalt-- & 2.95 & 59.26 & .70613 & -- & -- & -- & -- \\
\hline M 72-19 (2) & 1 & Trachyandesite-10 & 2.95 & 59.26 & .70633 & -- & -- & -- & -- \\
\hline CT 74-2 (3) & 1 & 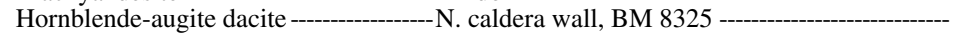 & 3.00 & 60.96 & .70596 & -- & -- & -- & -- \\
\hline D85-55 & 2 & 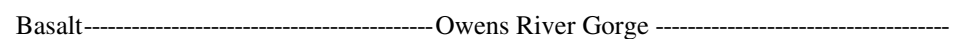 & 3.20 & 52.81 & .70609 & .51240 & -- & -- & -- \\
\hline D85-191 & 2 & do-- caldera rim - & 3.10 & 50.06 & .70595 & -- & -- & -- & -- \\
\hline D85-204 & 2 & do- & 3.00 & 48.70 & .70594 & -- & -- & -- & -- \\
\hline D85-235 & 2 & 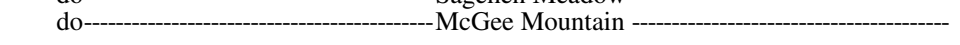 & 2.60 & 48.98 & .70623 & .51250 & -- & -- & -- \\
\hline MSTba & 6 & 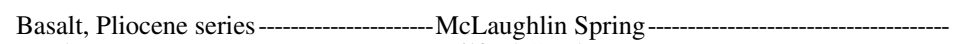 & -- & 51.95 & .70613 & .51245 & 18.93 & 15.66 & 38.87 \\
\hline WCTba & 6 & 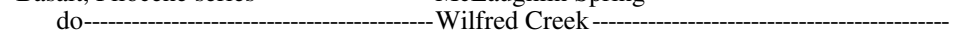 & -- & 48.28 & .70603 & .51247 & -- & -- & -- \\
\hline GSTba & 6 & do-- & -- & 49.32 & .70608 & .51249 & 18.90 & 15.63 & 38.80 \\
\hline
\end{tabular}


Table 6-Continued

\begin{tabular}{|c|c|c|c|c|c|c|c|c|c|c|}
\hline Sample & Reference & Rock type & Locality & $\begin{array}{l}\text { Age } \\
\text { (Ma) }\end{array}$ & $\begin{array}{c}\mathrm{SiO}_{2} \\
\text { (wt pct) }\end{array}$ & $\begin{array}{c}{ }^{87} \mathrm{Sr} /{ }^{86} \mathrm{Sr} \\
\text { ratio }\end{array}$ & $\begin{array}{c}{ }^{143} \mathrm{Nd} /{ }^{144} \mathrm{Nd} \\
\text { ratio }\end{array}$ & $\begin{array}{c}{ }^{206} \mathrm{~Pb} /{ }^{204} \mathrm{~Pb} \\
\text { ratio }\end{array}$ & $\begin{array}{c}{ }^{207} \mathrm{~Pb} /{ }^{204} \mathrm{~Pb} \\
\text { ratio }\end{array}$ & $\begin{array}{c}{ }^{208} \mathrm{~Pb} /{ }^{204} \mathrm{~Pb} \\
\text { ratio }\end{array}$ \\
\hline
\end{tabular}

\section{POSTCALDERA SEQUENCE}

\section{Caldera suite}

\begin{tabular}{|c|c|c|}
\hline DP 73-1 (14) & 1 & --W. moat flow. \\
\hline M 72-92 (15) & 1 & Hornblende-biotite trachydacite --------Earthquake Fault flow \\
\hline DP73-140 (16) & 1 & Biotite rhyolite----о--о-о \\
\hline D85-59 & 2 & Basalt-- \\
\hline L82-107 & 2 & 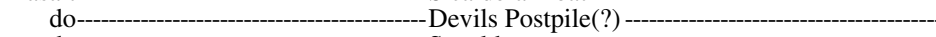 \\
\hline LV -10 & 5 & ---S. caldera moat --- \\
\hline TBQob-1 & 6 & Older basalt-_- Buttresses - \\
\hline TBQob-2 & 6 & 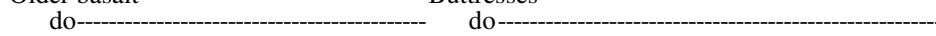 \\
\hline HLQpb & 6 & Basalt-- \\
\hline TFQpb & 6 & do--_- Lake Mamie outlet (Twin Falls) \\
\hline PBQa-1 & 6 & Trachyandesite---_- \\
\hline PBQa-2 & 6 & do--Pumice Butte (central) \\
\hline $\mathrm{PBQ}-3$ & 6 & do--Pumice Butte (southwest) \\
\hline RMQa & 6 & do- \\
\hline DPQpb & 6 & do-Devils Postpile (Postpile flow) \\
\hline DPQaq & 6 & Dacite --י-- Devils Postpile (Rainbow Falls flow) \\
\hline SSQab & 6 & Basalt-- \\
\hline MMQpb & 6 & do-_-SW. caldera moat - \\
\hline DCQgb-1 & 6 & 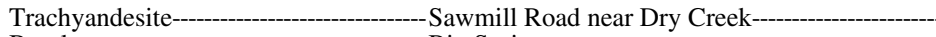 \\
\hline BSQpb & 6 & 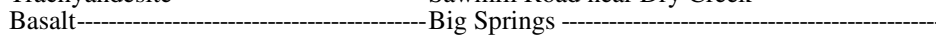 \\
\hline LMQa-1 & 6 & do-- NW. caldera moat--- \\
\hline LMQ -3 & 6 & 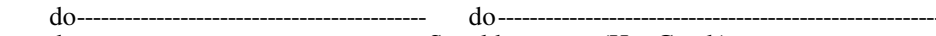 \\
\hline $\mathrm{HCQpb}$ & 6 & do \\
\hline MLQab & 6 & do-S. caldera moat (Mammoth Creek) \\
\hline LVQpb & 6 & do- \\
\hline DCQab & 6 & 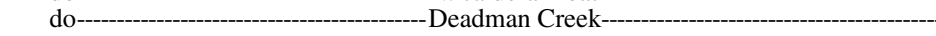 \\
\hline
\end{tabular}

\begin{tabular}{rrrlrrr}
0.10 & 50.92 & 0.70632 & -- & -- & -- & -- \\
.15 & 68.71 & .70629 & -- & -- & -- & -- \\
.05 & 70.55 & .70630 & -- & -- & -- & -- \\
.20 & 51.22 & .70599 & -- & -- & -- & -- \\
.60 & 51.83 & .70603 & .51252 & -- & -- & -- \\
.06 & -- & .70625 & -- & 19.24 & 15.70 & 38.99 \\
-- & 46.45 & .70646 & .51242 & 18.92 & 15.64 & 38.83 \\
-- & 47.02 & .70640 & .51239 & 18.90 & 15.60 & 38.71 \\
-- & 49.12 & .70670 & .51247 & 19.18 & 15.67 & 38.89 \\
-- & 49.05 & .70667 & .51248 & 19.21 & 15.70 & 38.98 \\
-- & 57.13 & .70628 & .51253 & 19.17 & 15.67 & 38.88 \\
-- & 56.83 & .70630 & .51252 & 19.18 & 15.68 & 38.89 \\
-- & 56.64 & .70629 & .51251 & -- & -- & -- \\
-- & 57.59 & .70633 & .51253 & 19.24 & 15.71 & 38.99 \\
-- & 53.92 & .70613 & .51229 & 19.17 & 15.68 & 38.89 \\
-- & 66.88 & .70636 & .51256 & 19.22 & 15.70 & 38.99 \\
-- & -- & .70596 & .51256 & 19.26 & 15.71 & 38.99 \\
-- & 50.85 & .70629 & .51255 & 19.24 & 15.71 & 39.01 \\
-- & 55.14 & .70623 & .51253 & 19.18 & 15.69 & 38.92 \\
-- & 50.78 & .70633 & .51252 & 19.24 & 15.69 & 38.97 \\
-- & 51.71 & .70620 & .51243 & 19.25 & 15.71 & 39.00 \\
-- & 51.14 & .70620 & .51253 & 19.23 & 15.70 & 38.95 \\
-- & 49.31 & .70591 & .51255 & 19.19 & 15.64 & 38.79 \\
-- & 51.48 & .70620 & .51250 & 19.27 & 15.70 & 38.98 \\
-- & 50.83 & .70634 & .51247 & 19.22 & 15.66 & 38.88 \\
-- & 53.21 & .70628 & .51247 & 19.20 & 15.68 & 38.92 \\
& & & & & & \\
\hline
\end{tabular}

Corehole Inyo-4 (depth in feet)

\begin{tabular}{|c|c|c|c|c|c|c|c|c|c|}
\hline 73.8 & 6 & 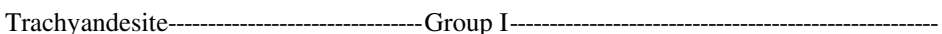 & 0.15 & 58.31 & 0.70638 & 0.51251 & 19.19 & 15.70 & 38.94 \\
\hline 127.8 & 6 & do-- & -- & 57.17 & .70631 & .51252 & 19.17 & 15.68 & 38.87 \\
\hline 405.8 & 6 & 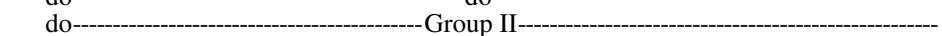 & - - & 55.99 & .70626 & .51248 & 19.16 & 15.68 & 38.88 \\
\hline 503.4 & 6 & 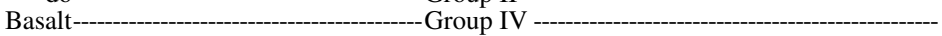 & - - & 50.14 & .70621 & .51252 & 19.20 & 15.73 & 39.06 \\
\hline 527.0 & 6 & Trachyandesite-1- & - - & 54.21 & .70620 & .51252 & 19.16 & 15.74 & 39.03 \\
\hline 540.4 & 6 & do--о-о & - - & 55.77 & .70622 & .51247 & 19.18 & 15.72 & 39.03 \\
\hline 686.6 & 6 & do- & - - & 55.01 & .70617 & .51253 & 19.19 & 15.68 & 38.90 \\
\hline 883.3 & 6 & Basalt & -_ & 53.05 & .70618 & .51251 & & & -1 \\
\hline $2,123.5$ & 6 & 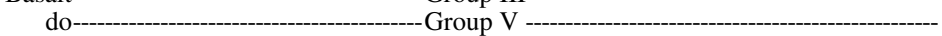 & - - & 50.50 & .70596 & .51259 & 19.17 & 15.67 & 38.86 \\
\hline $2,130.4$ & 6 & do- & - - & 50.28 & .70598 & .51257 & 19.23 & 15.74 & 39.07 \\
\hline $2,159.1$ & 6 & do---о-о-о-о-о-о-о-о-о-о-о-о-о-о-о-о-о-о-о & _- & 50.81 & .70597 & .51259 & 19.19 & 15.67 & 38.88 \\
\hline $2,209.0$ & 6 & do-- & .415 ? & 51.40 & .70597 & .51259 & 19.23 & 15.72 & 39.00 \\
\hline
\end{tabular}


Table 6-Continued

\begin{tabular}{|c|c|c|c|c|c|c|c|c|c|}
\hline Sample & Reference & Rock type & $\begin{array}{l}\text { Age } \\
\text { (Ma) }\end{array}$ & $\begin{array}{c}\mathrm{SiO}_{2} \\
\text { (wt pct) }\end{array}$ & $\begin{array}{c}{ }^{87} \mathrm{Sr} /{ }^{86} \mathrm{Sr} \\
\text { ratio }\end{array}$ & $\begin{array}{c}{ }^{143} \mathrm{Nd} /{ }^{144} \mathrm{Nd} \\
\text { ratio }\end{array}$ & $\begin{array}{c}{ }^{206} \mathrm{~Pb} /{ }^{204} \mathrm{~Pb} \\
\text { ratio }\end{array}$ & $\begin{array}{c}{ }^{207} \mathrm{~Pb} / 204 \mathrm{~Pb} \\
\text { ratio }\end{array}$ & $\begin{array}{c}{ }^{208} \mathrm{~Pb} /{ }^{204} \mathrm{~Pb} \\
\text { ratio }\end{array}$ \\
\hline \multicolumn{10}{|c|}{ Mono-Inyo suite } \\
\hline D85-56 & 2 & 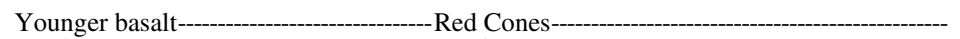 & $<0.01$ & 50.61 & 0.70516 & 0.51276 & 19.19 & 15.69 & 38.94 \\
\hline RCQyb-1 & 6 & do- & $<0.01$ & 49.98 & .70521 & .51277 & 19.22 & 15.68 & 38.91 \\
\hline RCQyb-2 & 6 & 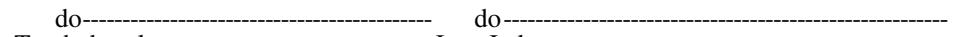 & $<0.01$ & 50.40 & .70531 & .51277 & 19.22 & 15.68 & 38.91 \\
\hline JLQa & 6 & 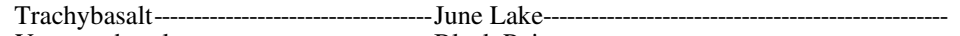 & -- & 53.34 & .70616 & .51258 & 19.25 & 15.67 & 38.89 \\
\hline BPQyb & 6 & Younger basalt--_- Black Point & -- & 50.55 & .70538 & .51267 & 19.22 & 15.66 & 38.83 \\
\hline BP83-1 & 3 & do-- & .013 & 50.40 & .70545 & .51272 & -- & -- & -- \\
\hline M14-1B & 3 & Andesite enclave --- & -- & 57.90 & .70526 & .51278 & -- & -- & -- \\
\hline Neg-RD2 & 3 & Dacite & -- & 65.00 & .70631 & .51253 & -- & -- & -- \\
\hline Pao-3 & 3 & 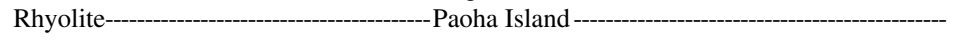 & -- & 71.70 & .70633 & .51265 & -- & -- & -- \\
\hline \multicolumn{10}{|c|}{ SIERRAN GRANITOIDS } \\
\hline RCKg & 6 & Granitoid --о-о-о-о-о-о-о-о-о-о-о-о-о-о-Near Red Cones --. & -- & 70.49 & 0.70779 & 0.51228 & 18.96 & 15.64 & 38.84 \\
\hline DPKg & 6 & do- & -- & 70.84 & .70751 & .51223 & 18.93 & 15.65 & 38.85 \\
\hline BSJg & 6 & 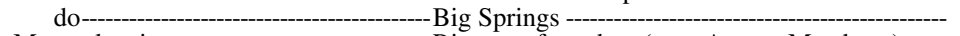 & -- & 73.37 & .70666 & .51261 & 19.29 & 15.66 & 38.98 \\
\hline Mzmv & 6 & Metavolcanic-_-_- Ritter roof pendant (near Agnew Meadows) ---- & -- & 65.23 & .72396 & .51238 & 18.94 & 15.71 & 38.82 \\
\hline R-99 & 8 & Evolution Basin alaskite - & 86 & -- & .71566 & .512479 & -- & -- & -- \\
\hline MG-1 & 8 & Lamarck granodiorite -о-о-о & 88 & -- & .70743 & .512431 & -- & -- & -- \\
\hline PAL-3 & 8 & Inconsolable granodiorite--------- & 107 & -- & .70666 & .512368 & -- & -- & -- \\
\hline PAL-61 & 8 & Tinemaha Plateau --'-- & 109 & -- & .70818 & .512215 & -- & -- & -- \\
\hline FD-20 & 8 & W. Sierra trondjhemite & 112 & -- & .70529 & .512571 & -- & -- & -- \\
\hline JB-1 & 8 & Bass Lake tonalite - & 118 & -- & .70737 & .512448 & -- & -- & -- \\
\hline CL-1 & 8 & 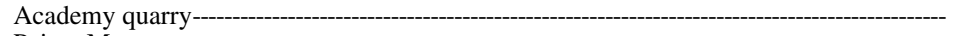 & 125 & -- & .70405 & .512884 & -- & -- & -- \\
\hline FD -3 & 8 & Paiute Monument - & 130 & -- & .70926 & .512163 & -- & -- & -- \\
\hline PAL-8 & 8 & Tinemaha Pluton - & 169 & -- & .71065 & .512180 & -- & -- & -- \\
\hline PAL-53x & 8 & do-- & 169 & -- & .70812 & .512195 & -- & -- & -- \\
\hline PAL -30 & 8 & 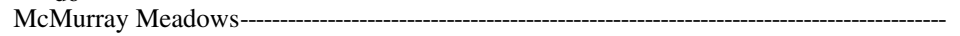 & 171 & -- & .70773 & .512299 & -- & -- & -- \\
\hline PAL-72 & 8 & do- & 171 & -- & .71683 & .512196 & -- & -- & -- \\
\hline MT-1 & 8 & Wheeler Crest granite-1 & 210 & -- & .70987 & .512224 & -- & -- & -- \\
\hline
\end{tabular}


a considerable body of evidence supports the associations of OIB-like basalts with an asthenospheric-mantle source and of enriched IAB-like basalts with a lithospheric-mantle source in the Western Great Basin.

\section{Long Valley Basalt Sources}

Many precaldera basalts in the Long Valley Volcanic Field satisfy the criteria for primitive lavas-that is, high $\mathrm{MgO}$ contents (8-10.5 weight percent), high $\mathrm{MgO} / \mathrm{FeO}$ ratios (Mg\#>60), and high compatible-element contents (>140

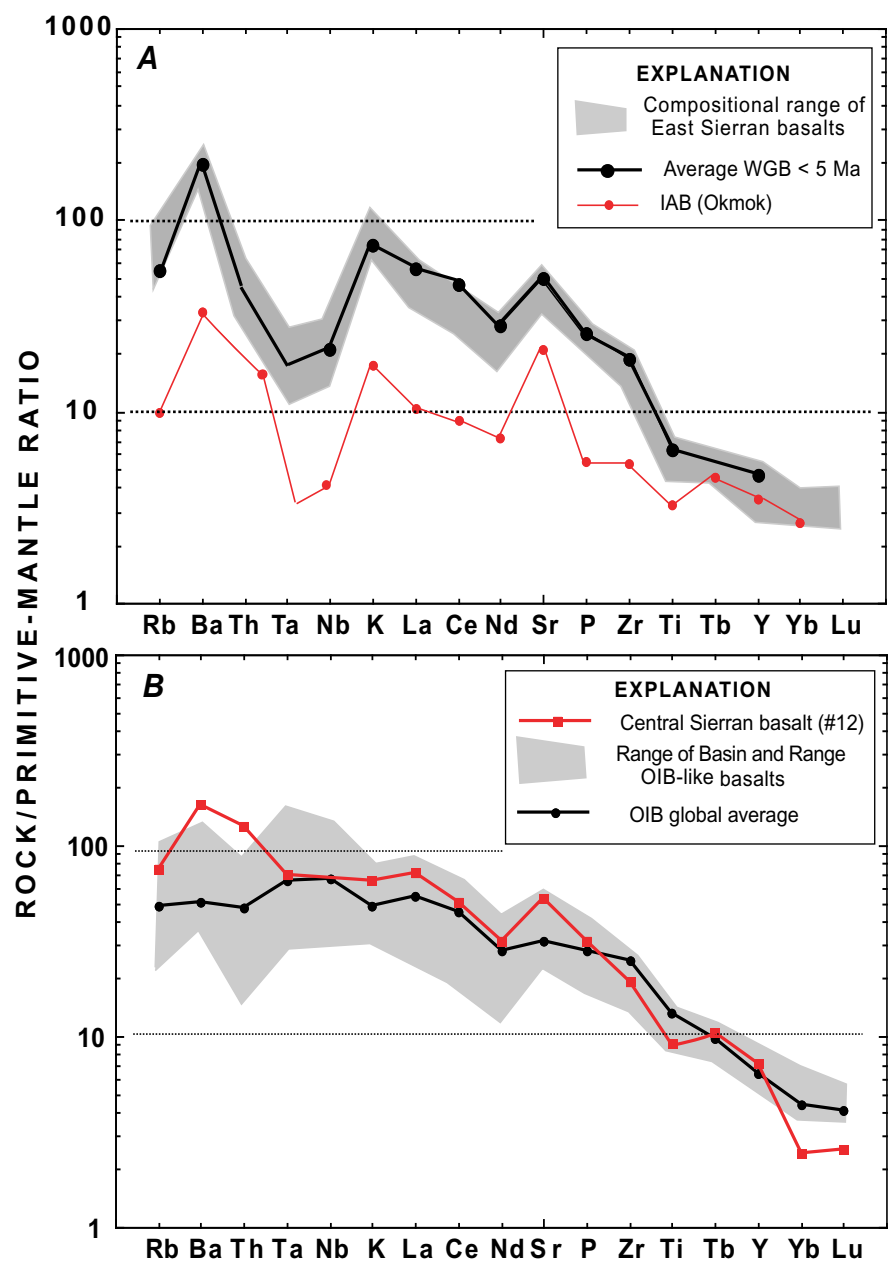

Figure 23. Mantle-normalized trace-element profiles of typical lithospheric- and asthenospheric-mantle-derived melts in the Basin and Range Province. A, Compositional range of East Sierran basalts in comparison with average Western Great Basin (WGB) lithospheric-mantle-derived basalt (Fitton and others, 1991) and primitive island-arc basalt (IAB) from Okmok, Aleutian Islands (sample ID16 of Nye and Reid, 1986). B, Central Sierran alkaliolivine basalt (sample 12 of Van Kooten, 1980) in comparison with OIB global average (Sun and McDonough, 1989) and compositional range of Basin and Range OIB-like basalts from Lunar Craters (Lum and others, 1989) and the Coso Volcanic Field (Novak and Bacon, 1986). ppm Ni, >200 ppm Cr) (Bacon and others, 1997). Precaldera basalts that meet these criteria include (1) all of the ultrapotassic Central Sierran basalts of Van Kooten (1980), (2) most East Sierran basalts (samples S1-S7, table 2), and (3) some of the more mafic Basin and Range basalts (samples B1, B2, B4, table 3). In contrast, only a few postcaldera basalts meet or approach these primitive criteria-for example, the Buttresses and Horseshoe Lake flows (samples C28, C27, table 4), which closely resemble precaldera basalts, and, possibly, the Early Rhyolite basalt enclaves (unit Qer, figs. 4-6; sample $\mathrm{C} 1$, table 4), which contains 7.1 weight percent $\mathrm{MgO}, 60 \mathrm{ppm}$ $\mathrm{Ni}$, and $215 \mathrm{ppm} \mathrm{Cr}$. The remaining postcaldera basalts are too deficient in $\mathrm{MgO}, \mathrm{Ni}$, and $\mathrm{Cr}$ (probably as a result of olivine fractionation at shallow crustal levels before eruption) to be considered primitive. The most mafic units, however, could have been parental to most other postcaldera mafic lavas; these few parental basalts include (1) the Early Rhyolite aphyric basalt enclaves (sample C1, table 4), (2) corehole Inyo-4 group V basalts (Vogel and others, 1994, tables 2, 3), (3) west-moat basalt (sample C3, table 4), (4) the south-moat Hot Creek basalt flow (sample HCQpb; Cousens, 1996, table 2), (5) the Devils Postpile Soda Spring flow (sample SSQab; Cousens, 1996, table 3), (6) Black Point basalt (sample M2, table 5), and (7) Red Cones basalt (sample M1, table 5). As a group, they have higher $\mathrm{Sr}$ - and lower $\mathrm{Nd}$-isotopic ratios than all other postcaldera basalts and plot closer to the isotopic range for OIB and MORB (fig. 20B).

\section{Precaldera Basalts}

Nearly all precaldera basalts, of both the Sierran and Basin and Range suites, have primitive-mantle-normalized trace-element signatures attributable to derivation from a lithospheric-mantle source (fig. 10). Van Kooten (1980, 1981) concluded that the ultrapotassic and potassic Central Sierran basaltic lavas were derived by 1.0 - to 2.5 -percent partial melting of alkali- and alkaline-earth-enriched, phlogopite- and garnet-bearing, pyroxene-rich lherzolite in the lithospheric mantle at 100- to 125-km depth. Van Kooten (1980) noted that at the few Central Sierran vents where stratigraphic relations are unambiguous, $\mathrm{K}_{2} \mathrm{O}$ content decreases upward in successive flows, suggesting an origin by increasing degrees of partial melting rather than fractional crystallization, which would have produced the opposite trend. Although source depletion might explain this decrease, it seems unlikely at such small degrees of partial melting. Van Kooten (1980) also noted the marked eastward decrease in $\mathrm{K}_{2} \mathrm{O}$ content within potassic Central Sierran lavas (fig. 9) and suggested, on the basis of the nonsystematic covariance of $\mathrm{K}_{2} \mathrm{O}$ with REE contents, that this regional change in $\mathrm{K}_{2} \mathrm{O}$ content was a source characteristic rather than a function of degree of partial melting. Thus, the local stratigraphic change in $\mathrm{K}_{2} \mathrm{O}$ content reflects inplace degree of partial melting, whereas the geographic variation in $\mathrm{K}_{2} \mathrm{O}$ content reflects a lateral change in composition of the lithospheric-mantle source. This conclusion is reinforced by 
gradual eastward changes in the $\mathrm{SiO}_{2}$ content, $\mathrm{Mg}$ number, $\mathrm{CaO} / \mathrm{MgO}$ and $\mathrm{Ce} / \mathrm{Yb}$ ratios, and $\mathrm{Y}$ content of basaltic lavas from the Central Sierran through East Sierran to Basin and Range suites (fig. 9). These systematic lateral changes (particularly in $\mathrm{Ce} / \mathrm{Yb}$ ratio, which is sensitive to garnet content in the source as well as to lithosphere thickness; Ellam, 1992) suggest a progressive change in source-rock composition in the lowermost lithospheric mantle-from garnet peridotite beneath the central Sierra Nevada to spinel peridotite beneath the Basin and Range - that, in turn, implies eastward thinning of the lithospheric mantle across the transition between the Sierra Nevada and Basin and Range Provinces, consistent with geophysical evidence for such eastward thinning across the East Sierran frontal fault zone (Carder, 1973; Mavko and Thompson, 1983; Wernicke and others, 1995; Fliedner and others, 1996).

Although the slightly more radiogenic Sr-isotopic composition of Central and East Sierran basalts relative to Basin and Range basalts (fig. 21A) could indicate greater contamination by crustal materials in passage through the thicker Sierran lithosphere, this effect is difficult to reconcile with the regional west-to-east decrease in $\mathrm{K}_{2} \mathrm{O}$ content (fig. 9). Central Sierran alkali-olivine basalt (sample 12 of Van Kooten, 1980), with its OIB-like signature and chemical and isotopic similarities to other OIB-like basalts of the Basin and Range Province (fig. 22A), supports derivation from an asthenospheric-mantle source, although its relatively high $\mathrm{Ba}, \mathrm{Th}$, and $\mathrm{Sr}$ contents and low $\mathrm{Yb}$ and Lu contents (fig. 11) could indicate cryptic crustal contamination (facilitated by its probable high temperature) during passage to the surface. The presence of OIB-like basalt, even in small amounts, indicates that at $3.8 \mathrm{Ma}$, asthenospheric-mantle source material existed above $80-\mathrm{km}$ depth beneath the central Sierra Nevada and that magmas from both lithospheric- and asthenospheric-mantle sources were being tapped simultaneously and in close proximity.

\section{Postcaldera Basalts}

Cousens (1996), in his study of Long Valley postcaldera mafic lavas, concluded that the more mafic ( $>7$ weight percent $\mathrm{MgO}$ ) parental basalts were derived from either a less enriched lithospheric-mantle source or (as he preferred) contributions from a mafic lower-crustal source, possibly gabbroic-dioritic rocks deep in the Sierra Nevada batholith. He further concluded that the less mafic basalts evolved predominantly by fractional crystallization and the trachyandesites by assimilation of Sierran granitoids - in agreement with earlier studies of the corehole Inyo-4 samples by Vogel and others (1994). Cousens added that although shifts toward lower $\mathrm{Sr}$ - and higher Nd-isotopic ratios in the younger postcaldera basalts suggest increasing involvement of an asthenospheric-mantle component (presumably OIB type), incompatible trace-element ratios and $\mathrm{Pb}$-isotopic data do not support such a conclusion. The results of the present study generally agree, but possible alternative basalt sources are discussed below.

\section{Buttresses and Horseshoe Lake Basalts}

The postcaldera Buttresses and Horseshoe Lake flows (samples C27, C28, table 4) mineralogically and chemically resemble precaldera East Sierran basalts and have generally similar trace-element profiles (fig. 14). Cousens (1996, p. 27686), on the basis of this similarity and probably influenced by designation of the Buttresses flows as "Older Basalt" (Bailey, 1989), considered them collectively to be the oldest basalts in the postcaldera sequence, possibly older than the Bishop Tuff. Geomorphic and stratigraphic relations, however, as noted above, indicate that the Buttresses flows may be as young as $130 \mathrm{ka}$ and that the Horseshoe Lake flows were erupted between 100 and $25 \mathrm{ka}$ and so are considerably younger than the oldest postcaldera basalts penetrated in corehole Inyo-4 and the basalt enclaves in the Early and Moat Rhyolites.

Though mineralogically and chemically similar to precaldera basalts, the Buttresses and Horseshoe Lake flows are distinctive in their relatively lower $\mathrm{K}$ and $\mathrm{Rb}$ contents and higher LREE and $\mathrm{Sr}$ contents (fig. 14). Particularly distinctive are their low mantle-normalized $\mathrm{K} / \mathrm{La}$ ratios $(<1)$, a feature also characteristic of most other Caldera basalts (figs. $14 B$, $14 C$ ). Such low normalized K/La ratios also are characteristic of some other Pleistocene basalts in the Basin and Range Province, for example, the Big Pine basalts (Ormerod and others, 1991) and the Crater Flat, Nev., basalts (Bradshaw and Smith, 1994, fig. 2; Yogodzinski and others, 1996, fig. 4b), as well as some Miocene-Pliocene basalts of the Rio Grande Rift, Colo.-N.Mex. (group 3 lavas of Leat and others, 1988). Such lavas constitute a subtype of IAB-like Basin and Range basalt in which low normalized $\mathrm{K} / \mathrm{La}$ ratios appear to be a source characteristic. Ormerod and others (1991), in their analysis of the source of the Big Pine lavas, suggested that such relative $\mathrm{K}$ (as well as $\mathrm{Rb}$ ) depletion is due to breakdown of phlogopite into amphibole in the lithospheric mantle; they speculated that $\mathrm{K}$ depletion may be related to previous (Miocene-early Pliocene) potassic volcanism in the Sierra Nevada Province. For Long Valley Caldera basalts, such $\mathrm{K}$ depletion could be related to the generation of potassic basalts of the precaldera Central and East Sierran suites. Low K and Rb contents might also indicate tapping of less enriched or more refractory domains higher in the lithospheric mantle, consistent with Ormerod and others' (1991) conclusion that the Big Pine basalts were derived from spinel lherzolite rather than garnet lherzolite.

\section{Caldera Basalts}

As noted above, most Caldera basalts have low mantlenormalized K/La ratios $(<1)$ but also more flattened, less spiked normalized trace-element profiles (less enriched in LILEs and LREEs and less depleted in HFSEs) than the Buttresses and Horseshoe Lake basalts (figs. 14A-14C) and most precaldera basalts (fig. 10). Their profiles closely resemble those of mafic-lower-crustal global averages (figs. 24A, 24B; Taylor and McLennan, 1985; Rudnick and Fountain, 1995), suggesting that the Caldera basalts may have been derived by nearly 
complete melting of mafic lower crust. Glazner and others (1991) proposed such a mechanism for the chemical variation in the Amboy and Pisgah Craters basalts of the Mojave Desert, suggesting that they were produced by varying amounts of mixing of mafic lower-crustal to midcrustal partial melts with asthenospheric-mantle melt and that the youngest eruptive rocks represent "nearly pure mafic crustal melts." Circumstantial evidence supporting this hypothesis was provided by Hanchar and others (1994) in their study of mafic-lowercrustal xenoliths from a mid-Tertiary dike swarm in the Paiute Mountains, southeastern California, which confirmed that the mafic lower crust beneath the Mojave Desert is, indeed, compositionally similar to the global average. Primitive Caldera basalts, with their relatively low $\mathrm{Sr}$ - and high $\mathrm{Nd}$-isotopic ratios $\left({ }^{87} \mathrm{Sr} /{ }^{86} \mathrm{Sr}=0.70521-0.70598,{ }^{143} \mathrm{Nd} /{ }^{144} \mathrm{Nd}=0.51258-0.51277\right)$, if derived predominantly from mafic lower crust, would require a relatively young, unradiogenic mafic lower crust.

Cousens (1996) rejected the involvement of OIB-type (Geronimo or Cima type) asthenospheric-mantle melt as a mixing component in the formation of postcaldera Long Valley basalts, concluding that its incompatible-element content is too high and its $\mathrm{Pb}$-isotopic ratio too low. Cousens also rejected MORB-type melt as a possible mixing component, on the basis of its low K/La ratio. However, the high $\mathrm{K} / \mathrm{La}$ ratio of some Mono-Inyo basalts is due to low REE contents, not high $\mathrm{K}$ contents - a characteristic of MORB melts. Thus, MORB (both normal [N-MORB] and enriched [E-MORB]) melts as source components are further evaluated here. Although MORB lavas are not recognized in the Long Valley area, they do occur in adjacent regions: N-MORB lavas occur in the Cenozoic Coast Range of western California, where Johnson and O'Neil (1984) inferred that they welled up into the "slab gap" during formation of the San Andreas transform fault; E-MORB is closely approximated by the high- $\mathrm{Al}_{2} \mathrm{O}_{3}$ olivine tholeiite (HAOT) lavas of the Cascade Range of northeastern California and the northwestern Basin and Range Province of eastern Oregon (Bacon and others, 1997). N-MORB and E-MORB (HAOT), in addition to their low or depleted incompatible-element contents, have $\mathrm{Pb}$ contents about a tenth of those of OIB, and so $\mathrm{Pb}$-isotopic mixtures would be dominated by the lithospheric-mantle or mafic-lower-crustal melt contribution. The calculated traceelement profile of a 50:50 mix of lithospheric-mantle-derived East Sierran basalt (represented by K-depleted sample S1, table 2) and average N-MORB (Sun and McDonough, 1989) yields a normalized trace-element profile nearly identical to that of most primitive Caldera basalts (fig. 24C), as well as to that of the mafic-lower-crustal global average.

\section{Mono-Inyo Basalts}

Mono-Inyo basalts have primitive-mantle-normalized trace-element signatures closely resembling that of the maficlower-crustal global average (fig. 24B). They differ from Caldera basalts in their higher mantle-normalized $\mathrm{K} / \mathrm{La}$ ratios $(>1)$, but this feature is due to their relatively lower LREE contents rather than to higher K contents (fig 14D)—a relation account- able for by mixing of greater proportions of LREE-depleted MORB melt with lithospheric-mantle or mafic-lower-crustal melt. As noted above, the low $\mathrm{Pb}$ content of MORB would not significantly alter the $\mathrm{Pb}$-isotopic ratio of the mixture. Moreover, consistent with their lower Sr- and higher Nd-isotopic ratios, Mono-Inyo basalts also have slightly less radiogenic ${ }^{207} \mathrm{~Pb} /{ }^{204} \mathrm{~Pb}$ and ${ }^{208} \mathrm{~Pb} /{ }^{204} \mathrm{~Pb}$ ratios (figs. $22 \mathrm{~B}, 22 \mathrm{C}$ ), consistent with involvement of a larger $\mathrm{N}-\mathrm{MORB}$ component than in Caldera basalts. The primitive-mantle-normalized trace-element profile of Mono-Inyo basalts (fig. 24C) can be approximated by a calculated 60:40 mix of average MORB (Sun and McDonough, 1989) and lithospheric-mantle-derived East Sierran basalt (represented by K-depleted sample S1, table 2).

Thus, mixing of MORB with locally derived lithosphericmantle melts can approximate the compositions of both Caldera and Mono-Inyo basalts. The tectonic relations for possible involvement of MORB in the origin of postcaldera Long Valley basalts are discussed below in the section entitled "Tectonomagmatic Model."

Additional perspective on the sources of Long Valley basalts is provided by figures $25(\mathrm{Ta} / \mathrm{La}$ versus $\mathrm{La} / \mathrm{Sm}$ ratios) and 26 ( $\mathrm{Th} / \mathrm{Yb}$ versus $\mathrm{Ta} / \mathrm{Yb}$ ratios), where Long Valley basalts are compared with the mafic-lower-crustal global average and N-MORB, E-MORB, and OIB compositions and their local equivalents.

In figure $25 A,{ }^{5}$ OIB-type lavas from the Coso, Lunar Craters, Cima, and Amboy-Pisgah Volcanic Fields in the Basin and Range Province form a vertical array, with a wide range of $\mathrm{Ta} / \mathrm{La}$ ratios in the middle of the diagram. Note that Central Sierran alkali-olivine basalt (sample 12) plots within this OIB array. Purported E-MORB-type (HAOT) lavas from the Cascade Range and eastern Oregon plot in a subparallel vertical array at lower $\mathrm{La} / \mathrm{Sm}$ ratios and an equally wide range of Ta/La ratios between N-MORB and E-MORB global averages. Precaldera Long Valley basalts (shaded field, without data points) form a subhorizontal array in the lower middle of the diagram. Most Caldera basalts overlap this precaldera array at similar $\mathrm{Ta} / \mathrm{La}$ ratios but at generally low $\mathrm{La} / \mathrm{Sm}$ ratios. Relative to Caldera basalts, Mono-Inyo basalts have higher Ta/La and lower $\mathrm{La} / \mathrm{Sm}$ ratios and are skewed toward the HAOT array and toward average N-MORB, E-MORB, OIB, and mafic-lowercrustal compositions, suggesting possible involvement of any one of these components. Mixing lines between a typical precaldera basalt (sample S1, table 2), inferred to be representative of lithospheric-mantle melt, and N-MORB, E-MORB, OIB, and mafic-lower-crustal global averages are plotted in figure $25 \mathrm{~B}$. Mono-Inyo June Lake (JL, sample M4, table 5) and Black Point (BP, sample M2, table 5) basalts lie along the lower-crustal mixing line (LC-S1) at ratios of 60:40 and 75:25, respectively, whereas Red Cones basalt (RC, sample M1, table 5) lies between the N-MORB and E-MORB mixing lines (N-S1 and E-S1, respectively), at a ratio of about 75:25. Although these plots should be viewed cautiously because of the scatter in Long

${ }^{5} \mathrm{Ta} / \mathrm{La}$ ratio, rather than the more commonly plotted $\mathrm{Nb} / \mathrm{La}$ ratio, is used because for many of the basalts $\mathrm{Nb}$ data are unavailable. Furthermore, Ta content can be determined with good accuracy and precision. 
Valley data points, the more mafic parental Caldera basalts and Mono-Inyo basalts fall within this array of mixing lines.

A plot of $\mathrm{Th} / \mathrm{Yb}$ versus $\mathrm{Ta} / \mathrm{Yb}$ ratios (fig. 26) is instructive in that it separates the effects of mantle-enrichment processes from those of crustal contamination and mixing (Pearce, 1982). Because mantle-enrichment events affect Th and Ta contents equally, the vector for the mantle array has a slope of 1; however, crustal-contamination and mixing events affect Th more profoundly than Ta contents, and so the vector for such processes is subvertical. Using Yb content as a normalizing factor largely eliminates the effects of partial melting and fractional crystallization. Thus, most OIB-like Western Great Basin basalts, including those of the Coso, Lunar Craters, Cima, and Amboy-Pisgah Volcanic Fields, lie within the mantle array near the OIB global average. Note, however, that OIB-like alkali-olivine basalt (sample 12) of the Long Valley Central Sierran suite plots close to, but above, the mantle array on a subvertical vector, suggesting contamination by crustal
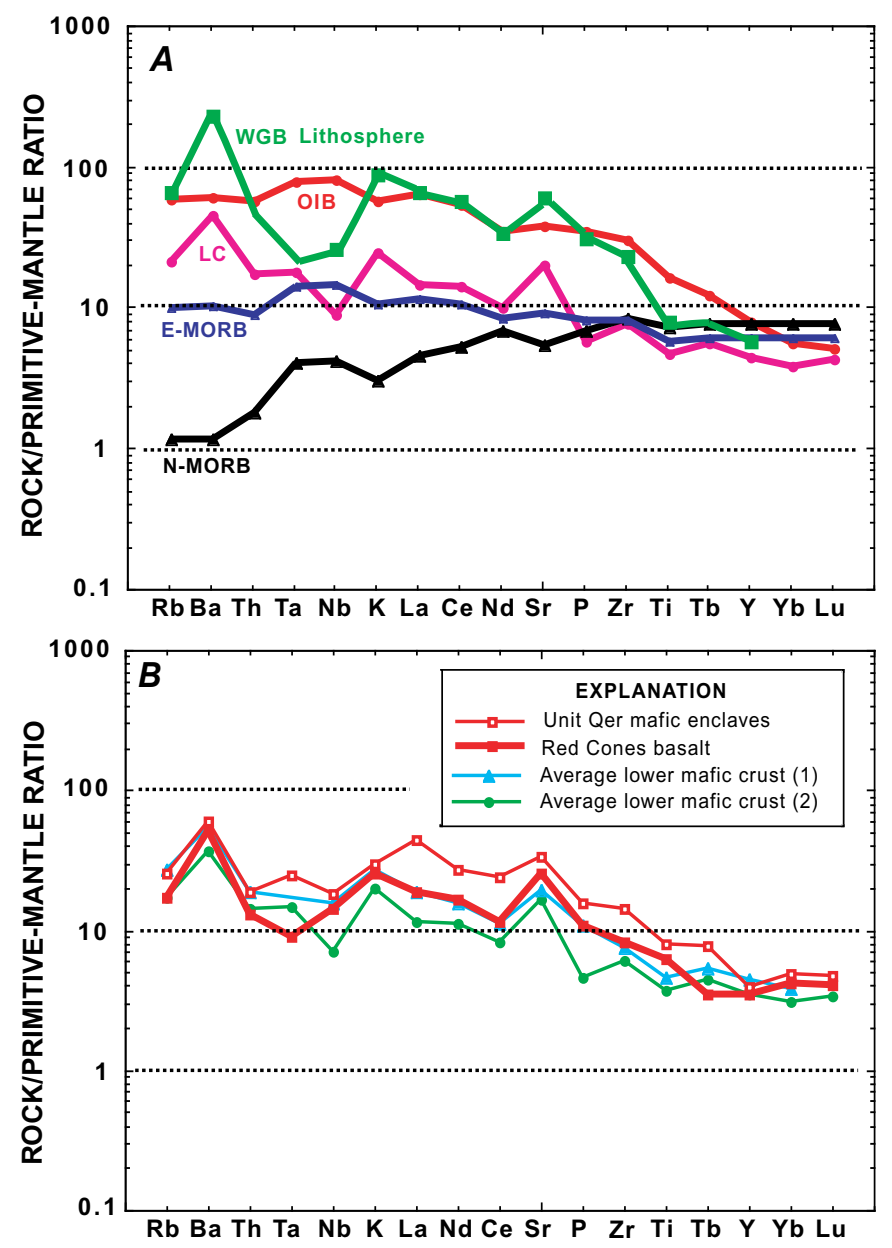

rocks, possibly Sierran granitoids. Other precaldera basalts cluster in a field well above the mantle array and in the general range for Big Pine and most other lithospheric-mantle-derived Basin and Range basalts. Caldera basalts form a vertical array between the precaldera basalt field and the mantle array, in the general vicinity of the mafic-lower-crustal global average (LC), with the most mafic parental basalts clustering close to the lower-crustal average at the edge of the mantle array. Mono-Inyo basalts of June Lake (JL) and Black Point (BP) fall within the Caldera array, but Red Cones basalt (RC) lies well to the left on an apparent subvertical vector, suggesting derivation from mantle magma intermediate in composition between N-MORB and E-MORB and possibly contaminated by or mixed with a lithospheric-mantle component, in general agreement with the mixing lines suggested in figure $25 \mathrm{~B}$.

Note where the Long Valley dacites plot in figure 26. Precaldera East Sierran dacites fall within the field of Sierra Nevada granitoids, whereas Basin and Range dacites plot within the field of precaldera basalts. Postcaldera dacites/ trachydacites also plot within the precaldera basalt field at somewhat lower $\mathrm{Th} / \mathrm{Yb}$ and $\mathrm{Ta} / \mathrm{Yb}$ ratios. These relations and supporting isotopic evidence suggest that the East Sierran dacites were derived by fusion of Sierran granitoids and Basin and Range dacites mainly by fractionation of associated mafic magmas. Anomalously, postcaldera dacites/trachydacites appear to be associated with precaldera basalts.

\section{Evolution of the Precaldera Sequence}

\section{Central and East Sierran Suites}

Precaldera Central Sierran, East Sierran, and Basin and Range basalts of the Long Valley Volcanic Field have chemical

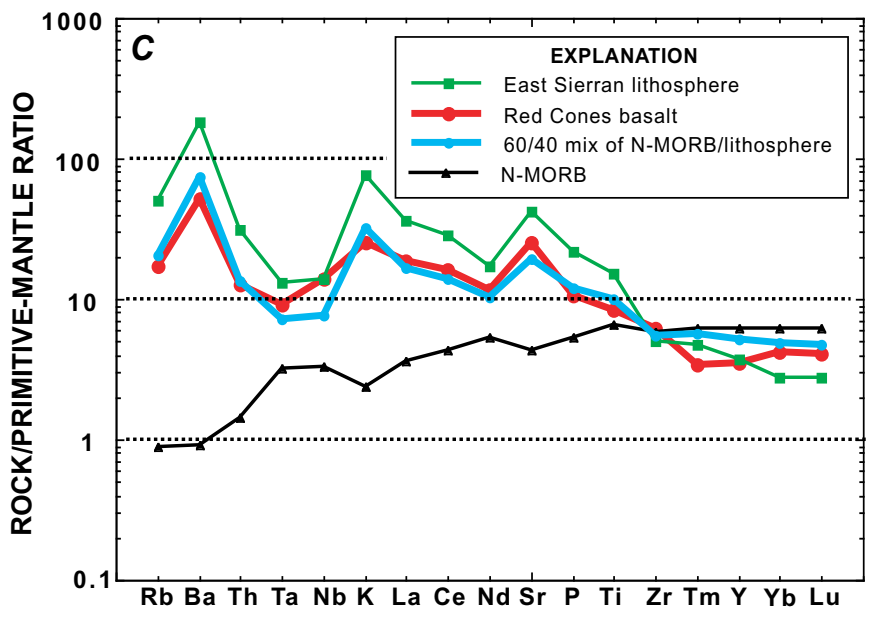

Figure 24. Primitive-mantle-normalized trace-element profiles of postcaldera basalts in comparison with representative global basalt types. $A$, Trace-element profiles of average global basalt types: ocean-island basalt (OIB), enriched midocean-ridge basalt (E-MORB), normal ocean-ridge basalt (N-MORB) (Sun and McDonough, 1989), mafic lower crust (LC) (Rudnick and Fountain, 1995), and average basalt derived from Western Great Basin (WGB) lithospheric mantle (Fitton and others, 1991). B, Trace-element profiles of primitive Caldera basalt (Unit Qer mafic enclaves) and Mono-Inyo basalt (Red Cones basalt) in comparison with mafic-lower-crustal global averages (1, Taylor and McLennon, 1985; 2, Rudnick and Fountain, 1995). C, Trace-element profile of primitive Mono-Inyo basalt (Red Cones basalt) in comparison with calculated 60/40 mix of N-MORB and lithospheric-mantle melt (represented by East Sierran basalt sample S1, table 2). 
and isotopic signatures indicating that most of the basalts were derived mainly from lithospheric mantle, though probably from different depths or chemical domains within it. Contrasting chemical trends within these suites, however, suggest that the chemically more evolved trachyandesites and dacites of each suite were generated by substantially different magmatic processes.

One of the striking differences between the East Sierran and Basin and Range suites is the predominance of compositional gaps in the East Sierran suite, in comparison with the more nearly continuous secular trend in the Basin and Range suite (figs. 7, 8). Although compositional gaps in lava suites are commonly attributed to fractionation mechanisms in closed magmatic systems (Grove and Donnelly-Nolan, 1986; Bacon and Druit, 1988; Brophy and others, 1996), trends of trace-element and, particularly, REE versus $\mathrm{SiO}_{2}$ contents in
East Sierran mafic lavas (figs. $8 B, 8 C$ ) indicate that basalt fractionation did not lead to the generation of most associated trachyandesites. The nearly straight-line relation between the gap-separated East Sierran basalt, trachyandesite, and dacite clusters for most elements (figs. $7 A, 8 A-8 C$ ) is consistent with magma mixing of silicic and mafic end members. Magma mixing is further supported by (1) the abundance of mafic enclaves in East Sierran dacites, in comparison with their relative paucity in Basin and Range dacites; (2) the presence in Sierran trachyandesites of resorbed plagioclase and augitehaloed quartz xenocrysts, commonly of volcanic (magmatic) rather than Mesozoic plutonic origin; (3) resorption and reaction textures in olivine and augite phenocrysts; (4) steep fractionation trends in East Sierran basalts that do not project toward trachyandesitic compositions; (5) the crossover pattern on normalized trace-element and REE diagrams for East Sier-

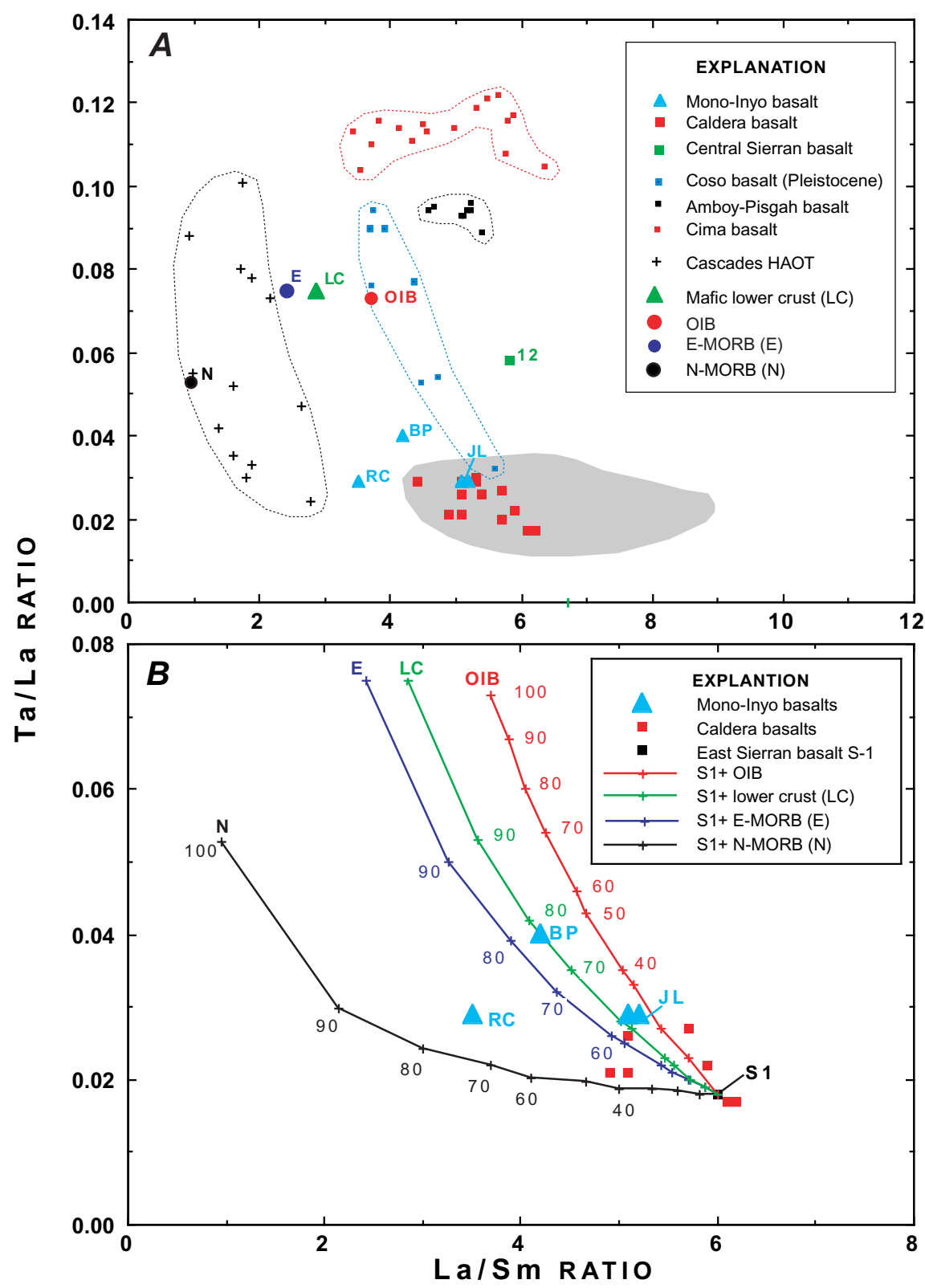

Figure 25. Ta/La versus $\mathrm{La} / \mathrm{Sm}$ ratios. $A$, Precaldera (gray area) and postcaldera basalts in relation to other Basin and Range basalts and Cascades high- $\mathrm{Al}_{2} \mathrm{O}_{3}$-olivine tholeiites (HAOT), as well as average ocean-island basalt (OIB), normal midocean-ridge basalt (N-MORB), enriched midocean-ridge basalt (E-MORB), and mafic lower crust (LC). $B$, Mixing lines between lithospheric-mantle melt (represented by East Sierran basalt, sample S1, table 2) and global averages for OIB, N-MORB, E-MORB, and mafic lower crust. (Note change in scale.) Note that June Lake (JL) and Black Point (BP) basalts lie on mafic-lower-crust mixing curve and that Red Cones (RC) basalt lies between $\mathrm{N}-\mathrm{MORB}$ and $\mathrm{E}-\mathrm{MORB}$ mixing curves, far to left of mafic-lower-crust mixing curve. 
ran trachyandesites (fig. 12), which is permissive of mixing of extreme end members; (6) calculated basalt fractionation trends that do not yield compositions resembling associated trachyandesites; and (7) least-squares mixing calculations, using local basalt and dacite as end members, that yield compositions close to those of East Sierran trachyandesites. The observed range of trachyandesitic compositions (55-60 weight percent $\mathrm{SiO}_{2}$ ) indicates basalt:dacite mixing ratios ranging from 38:62 to 67:33; this limited compositional range and, particularly, the relatively small gap between basalts and trachyandesites may be a function of the contrasting physical properties of the end members and the vagaries of the mixing process (Sparks and Marshall, 1986; Frost and Mahood, 1987). Some East Sierran trachyandesites, however, may have been generated from basalt by assimilation of Mesozoic granitoids, many of which are compositionally similar to precaldera East Sierran dacites. This mechanism is supported by (1) the close spatial and temporal association and superposed stratigraphic relations of some basalts and trachyandesites in the field; (2) the textural similarity of basalts and trachyandesites, both of which are finely porphyritic; and (3) basalt-trachyandesite sequences commonly showing continuous upsection changes in phenocryst compositions (Chaudet, 1986), in spite of the compositional gap between them. However, mixing calculations of basalt with local selected granitoid compositions produce less satisfactory solutions than mixing with coeval East Sierran dacitic compositions.

The higher $\mathrm{K}_{2} \mathrm{O}, \mathrm{Rb}$, Th, Ta, $\mathrm{Zr}$, and REE contents and lower $\mathrm{Na}_{2} \mathrm{O}$ content of East Sierran dacites relative to Basin and Range dacites (fig. 8) supports the generation of East Sierran dacites by fusion of an incompatible-element-enriched crustal source rock. East Sierran dacites are too radiogenic in $\mathrm{Sr}$ (fig. 21) to have been generated by fractionation of East Sierran basalts; involvement of a more radiogenic component, such as midcrustal to upper-crustal Mesozoic granitoids $\left({ }^{87} \mathrm{Sr} /{ }^{86} \mathrm{Sr}=0.70666-0.70987\right)$, seems required. As plotted in figure 26 ( $\mathrm{Th} / \mathrm{Yb}$ versus $\mathrm{Ta} / \mathrm{Yb}$ ratios), precaldera East Sierran dacites fall within the array of Sierra Nevada granitoids, suggesting fusion of such rocks as a possible origin; however, the marked depletion of $\mathrm{P}, \mathrm{Zr}$, Ti, Y, and HREEs in the dacites suggests probable late-stage fractionation of hornblende, along with apatite, zircon, and Fe-Ti oxides.

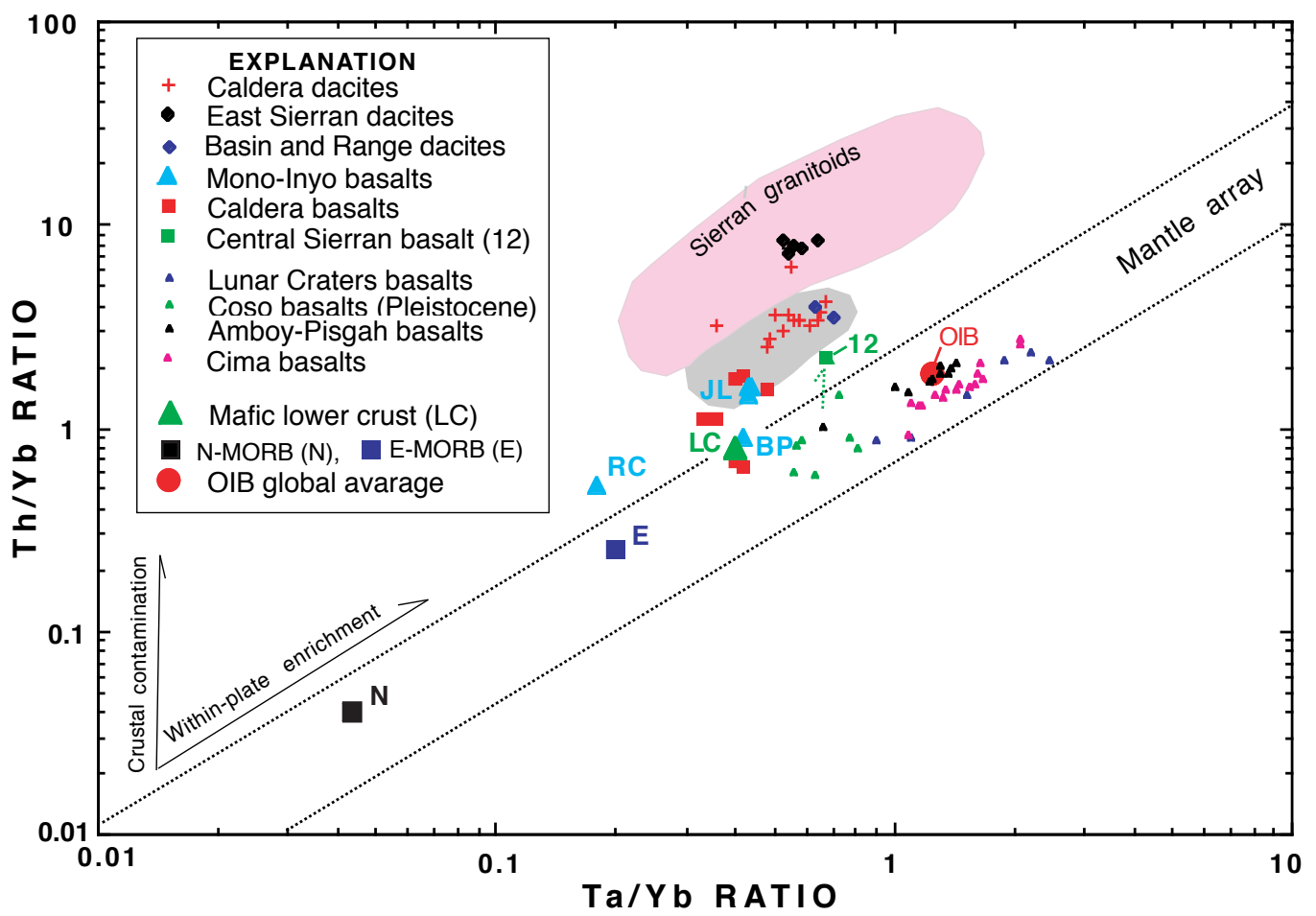

Figure 26. Th/Yb versus $\mathrm{Ta} / \mathrm{Yb}$ ratios for precaldera and postcaldera lavas, showing relation to "mantle array" (Pearce, 1982) and other Basin and Range lavas and related rocks. Gray area, compositional range of lithospheric-mantle-derived precaldera basalts; pink area, range of upper-crustal Sierran granitoids. OIB-like Basin and Range basalts cluster within mantle array near OIB global average; OIB-like sample 12 plots above mantle array, probably owing to crustal contamination. Caldera basalts and Mono Inyo basalts (JL, BP) plot between lithospheric-mantle-derived basalts and mafic-lowercrust global average (LC), whereas Red Cones (RC) basalt plots to left toward MORB (E, N) compositions. Note that precaldera Basin and Range dacites and most postcaldera dacites plot within range of lithospheric-mantle-derived basalts, whereas precaldera East Sierran dacites plot within range of Sierran granitoids. 


\section{Basin and Range Suite}

The more nearly continuous arcuate trend of Basin and Range lavas on $\mathrm{SiO}_{2}$-variation diagrams (figs. 7, 8A, 8B) suggests an evolution controlled initially by partial fusion of a heterogeneous upper-mantle source to produce both basalt and trachyandesite, followed by crystal fractionation to produce dacite. The increase in LREE contents with increasing $\mathrm{SiO}_{2}$ content from basalt to trachyandesite (fig. $8 \mathrm{C}$ ) suggests generation by partial fusion of a mafic pyroxene- and/or hornblende-bearing source. The following decrease in both LREE and HREE contents from trachyandesite to dacite suggests fractionation of hornblende and plagioclase. The absence of a dacite Eu anomaly (fig. 12B) may result from compensating positive and negative Eu anomalies in hornblende and plagioclase, respectively (Zielinski, 1975; Zielinski and Lipman, 1976). However, although fractionation of hornblende and plagioclase can account for most major-element trachyandesitedacite trends, it does not readily account for many traceelement trends. The overall decrease in mantle-normalized trace-element contents with increasing $\mathrm{SiO}_{2}$ content (fig. 12A) seems to require partial fusion of some mafic to intermediatecomposition source rock, probably accompanied or followed by fractionation of hornblende and plagioclase. Again, as plotted in figure 26, precaldera Basin and Range dacites fall within the field of precaldera basalts, consistent with an origin by fractionation of associated Basin and Range basalts or partial fusion of mafic lithospheric mantle.

\section{Summary}

In the Sierra Nevada Province, (1) Central and East Sierran basaltic lavas were derived by partial melting of lithospheric-mantle sources-ultrapotassic Central Sierran lavas by small degrees of partial melting of a phlogopite-bearing garnet peridotite near the base of a 100- to 125-km-thick upper mantle, as proposed by Van Kooten (1980), and East Sierran basalts by greater degrees of partial melting of garnet-poor peridotite at shallower mantle levels; (2) East Sierran dacites were derived by fusion of granitoid crustal rocks with relatively high incompatible-element contents, and subsequently modified by fractionation of hornblende and accessory minerals; and (3) most East Sierran trachyandesites were derived by mixing of coeval basaltic and dacitic end members, and some by assimilation of Mesozoic granitoids.

In the adjacent Basin and Range Province, chemical and mineralogic relations imply that (1) basaltic lavas were derived by partial melting of a thinned lithospheric mantle composed of spinel lherzolite and (2) trachyandesites and dacites evolved mainly by fractionation of hornblende and plagioclase.

The rare occurrence in the Central Sierran suite of a mafic nodule-bearing alkali-olivine basalt (sample 12, fig. 11) with OIB-like chemical and isotopic signatures indicates that asthenospheric-mantle magma was involved in the evolution of the Long Valley Volcanic Field at an early stage. Asthenospheric-mantle magma may have been present at depth in greater volume than is suggested by its eruptive volume, and may have provided the heat for melting of lithospheric-mantle and crustal sources to generate the precaldera basaltic through dacitic magmas. The slightly LILE enriched composition of this alkali-olivine basalt may be due to small degrees of partial melting or to contamination by upper-crustal rocks facilitated by its higher temperature relative to lithospheric mantlederived lavas. In general, however, most precaldera mafic lavas show little contamination by upper-crustal rocks, probably because during early stages of development of the volcanic field when extension was rapid, mafic magmas traveled rapidly to the surface and seldom stalled at crustal levels.

\section{Evolution of the Postcaldera Sequence}

\section{Caldera and Mono-Inyo Suites}

\section{Basalt}

The most mafic, parental basalts of the postcaldera sequence-including the mafic enclaves in units Qer and Qmr (fig. 2), a few early west-moat flows of the Caldera suite, and the Red Cones and Black Point units of the Mono-Inyo suitehave modified IAB-like, mantle-normalized trace-element signatures, with significantly lower LILE contents, higher HFSE contents (fig. 14), and lower $\mathrm{Sr}$ - and higher Nd-isotopic ratios (fig. 20) relative to lithospheric-mantle-derived precaldera basalts (fig. 18). Their trace-element signatures (figs. 14, 24) closely resemble those of lower-mafic-crustal global averages (Taylor and McLennon, 1985; Rudnick and Fountain, 1995), suggesting that these parental basalts were generated by partial melting of a mafic-lower-crustal source, although such characteristics may also be explained by mixing of LREE-depleted, MORB-like (particularly N-MORB) mantle melts with lithospheric-mantle-derived melts. This alternative explanation is supported, particularly for the Mono-Inyo basalts, by their relatively low Sr- and high Nd-isotopic ratios (fig. 20B), lower incompatible-element and LREE contents (fig. 14D), and progressively decreasing LREE contents over time, suggesting progressively greater input of an N-MORB-like component.

\section{Trachyandesite}

The more evolved trachybasalts and trachyandesites of the Caldera and Mono-Inyo suites have undergone varying degrees of contamination and commingling with more silicic materials. Studies of the small-volume mafic enclaves in postcaldera Early and Moat Rhyolites and in Mono-Inyo rhyolites (Varga and others, 1990; Kelleher and Cameron, 1990) provide welldocumented evidence of mixing and commingling with their host rocks at shallow crustal levels. The more voluminous Caldera basalt and trachyandesite flows, particularly those in the west moat, have had a more complex history involving the successive incorporation of two different magmatic contaminants at midcrustal to upper-crustal levels, as well recorded in the chemical variations (fig. 27) of corehole Inyo-4 
basalt-trachyandesite groups I through V (Vogel and others, 1994), wherein each successive group represents a separate magma batch that first was modified by assimilation of basement granodiorite (between-group variation) and subsequently evolved by crystal fractionation (within-group variation).

However, although most within-group major-element variations can be explained by crystal fractionation, the marked increases in $\mathrm{Ba}$ and $\mathrm{K}_{2} \mathrm{O}$ contents (Vogel and others, 1994, fig. 13) cannot but instead require preferential ingestion of $\mathrm{Ba}$ and $\mathrm{K}_{2} \mathrm{O}$ from a Ba+K $\mathrm{K}_{2} \mathrm{O}$-rich source. Vogel and others (1994) convincingly demonstrated that the bulk assimilation of Ba-rich Moat Rhyolite cannot account for these increases; however, selective diffusion of $\mathrm{Ba}$ and $\mathrm{K}$ at basalt/rhyolite interfaces, a process demonstrated experimentally by Watson (1982) and cited for similar $\mathrm{Ba}$ and $\mathrm{K}_{2} \mathrm{O}$ enrichment in Coso basalts (Bacon and Metz, 1984), may be a likely enrichment mechanism. Moat
Rhyolite sanidine phenocrysts (15 volume percent) contain 12,000 to 15,000 ppm Ba (R.A. Bailey, unpub. data, 1978) and typically are strongly resorbed, probably as a result of heating during basalt influx into the postcaldera residual Long Valley silicic-magma chamber. In addition to the sensible heat of the injected basalt, some of the thermal energy for melting of these Moat Rhyolite sanidine phenocrysts and for $\mathrm{Ba}$ and $\mathrm{K}$ diffusion and assimilation may have been provided by crystallization and separation of olivine and Fe-Ti oxides, as suggested by strong $\mathrm{Ni}$ and $\mathrm{Cr}$ depletion in most such contaminated intracaldera basalts (fig. 16). These variations in $\mathrm{Ba}$ and $\mathrm{K}_{2} \mathrm{O}$ contents suggest a two-stage, dual-level process whereby (1) betweengroup major-element variations were generated by assimilation of Mesozoic granodiorite during upward passage through the midcrust (or, alternatively, by mixing with postcaldera dacitic magma; see next subsection), and (2) marked within-group $\mathrm{Ba}$

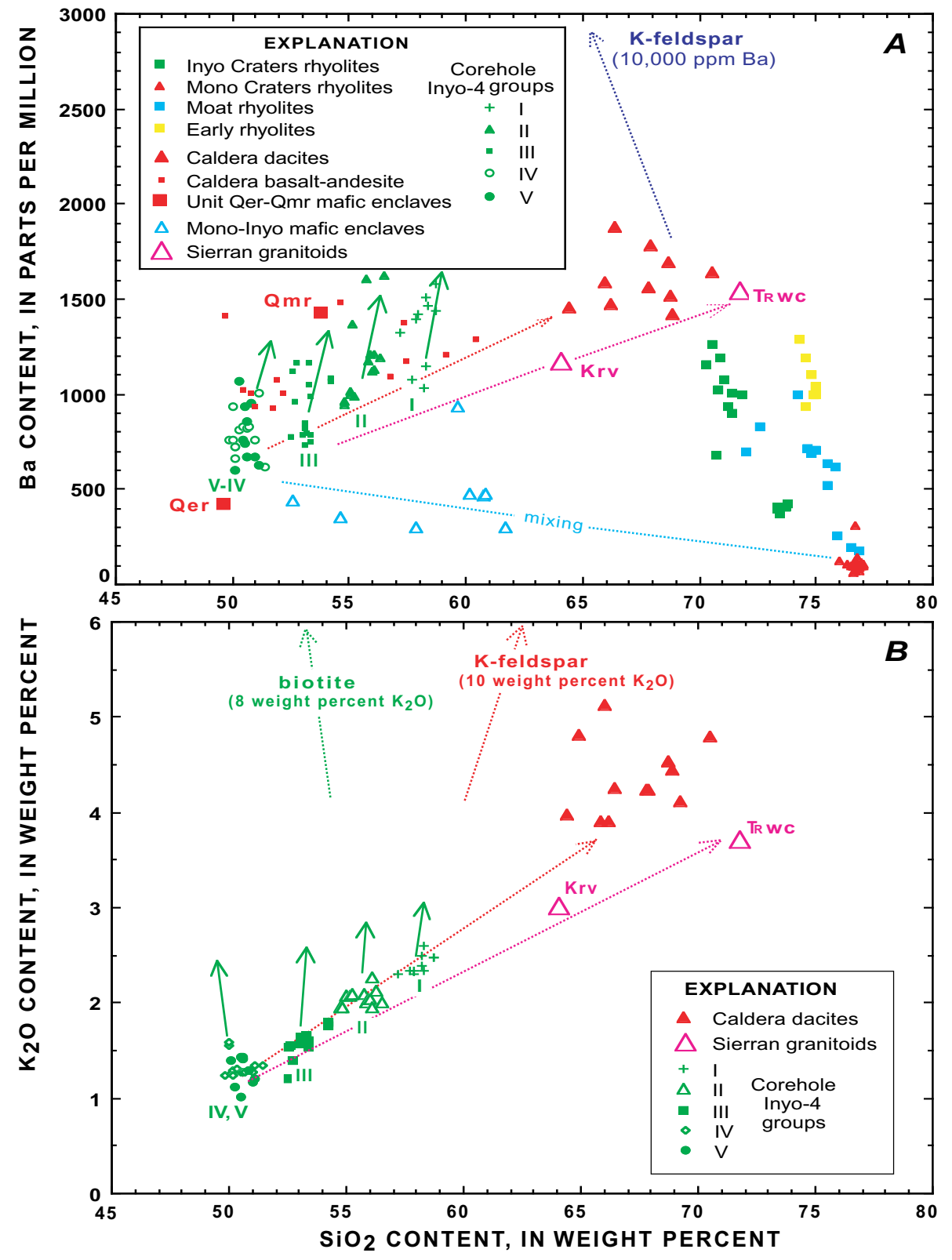

Figure 27. $\mathrm{SiO}_{2}$-variation diagrams illustrating chemical evolution of Caldera basalts and trachyandesites (groups I-V; Vogel and others, 1994). A, Ba versus $\mathrm{SiO}_{2}$ contents, showing two-stage $\mathrm{Ba}$ enrichment: (1) moderate between-group $\mathrm{Ba}$ enrichment by granitoid assimilation or dacite mixing, and (2) marked within-group $\mathrm{Ba}$ enrichment by selective diffusion from Ba-rich sanidine in Moat Rhyolite magma at margin or roof of residual Long Valley silicic-magma chamber. Note that trends for all postcaldera rhyolites project along lines that suggest derivation from dacite. Krv, Round Valley Peak granodiorite; TRwc, Wheeler Crest granite, both Sierran plutons cut by Long Valley ring-fault zone. $B, \mathrm{~K}_{2} \mathrm{O}$ versus $\mathrm{SiO}_{2}$ contents of groups $\mathrm{I}-\mathrm{V}$, showing similar but less marked within-group $\mathrm{K}$ enrichment, but between-group K enrichment consistent with dacite mixing. 
and $\mathrm{K}_{2} \mathrm{O}$ enrichment was achieved by selective diffusion from sanidine-rich Moat Rhyolite magma at the base or margin of the residual Long Valley silicic-magma chamber.

\section{Basalt-Dacite Mixing}

Although Vogel and others (1994) suggested Round Valley Peak granodiorite as the assimilant for between-group basalttrachyandesite compositional variations, chemically similar coeval dacitic magma is an equally, if not more likely, assimilant, requiring less thermal input and falling compositionally closer to the projected between-group mixing line than local Round Valley Peak granodiorite or Wheeler Crest granite (figs. $27 A, 27 B$ ). Petrographic evidence from the solitary intracaldera trachyandesite flow that plots within the postcaldera trachyandesite-dacite compositional gap (fig. 7C) also supports such mixing of basaltic and dacitic magma. As previously noted, this flow (sample C12, table 4), a 60-weight-percent- $\mathrm{SiO}_{2}$ "olivine quartz latite" (Rinehart and Ross, 1964, p. 57-60), contains relict magnesian olivine and augite phenocrysts from a basaltic component and biotite, hornblende, plagioclase, and partially resorbed augite-haloed quartz phenocrysts from a dacitic component in a thoroughly homogenized matrix within which no intact relict mafic enclaves are preserved. Least-squares mixing calculations, utilizing local basalt and dacite end members, indicate a basalt:dacite mixing ratio of 43:57.

\section{Dacite}

For most major elements and $\mathrm{Ba}, \mathrm{Th}$, and LREEs, postcaldera dacites are compositionally similar to precaldera East Sierran dacites (fig. 13). However, the much lower Sr-isotopic ratios of postcaldera dacites (fig. $21 B$ ) relative to local batholithic rocks and precaldera dacites (fig. 21A) indicate that the postcaldera dacites were likely derived by fractionation of their associated postcaldera basalts, which have similar Sr-isotopic ratios.

As noted above, porphyritic dacites of the Caldera and Mono-Inyo suites are mineralogically and chemically extremely diverse and probably evolved, except for the Mammoth Mountain complex, as small, isolated, unrelated magma batches. Although the contents of many major elements and $\mathrm{Sr}$ (figs. 13A, 13B) monotonically change with $\mathrm{SiO}_{2}$ content, suggesting that as a group they evolved by crystal fractionation, the porphyritic dacites were not necessarily derived from a common source or evolved in a single chamber. Postcaldera dacites (figs. 15A-15C), in comparison with precaldera East Sierran dacites (fig. 12A), are less enriched in $\mathrm{Sr}$ and less depleted in $\mathrm{Ta}, \mathrm{Nb}$, and $\mathrm{Ti}$. These trace-element profiles of postcaldera dacites closely mimic those of the associated postcaldera basalts, suggesting an origin, at least partly, by basalt fractionation, consistent with their similar isotopic compositions. The crystal-poor and somewhat less silicic Mono-Inyo dacites (fig. 15C) have higher Sr, P, and Ti contents, and appear to be slightly less evolved, than the porphyritic dacites. Though erupted later than the porphyritic dacites, Mono-Inyo dacites probably represent the deeper melts from which the porphyritic dacites were fractionated.
Although the postcaldera low- $\mathrm{SiO}_{2}$ rhyolites of both the Caldera and Mono-Inyo suites (fig. 15D) are chemically similar in most respects, the Mono-Inyo rhyolites are more depleted in REEs, particularly HREEs, and have slightly larger negative $\mathrm{Eu}, \mathrm{Ti}, \mathrm{Ta}$, and $\mathrm{Nb}$ anomalies, suggesting greater fractionation of plagioclase and, possibly, a cryptic Ti-bearing phase. These rhyolites most likely evolved by fractionation of coeval postcaldera dacites, also the likely origin of most other postcaldera rhyolites of the Long Valley Volcanic Field. $\mathrm{Ba}-\mathrm{SiO}_{2}$ trends of all postcaldera rhyolite groups, including the Early Rhyolite, Moat Rhyolite, and Mono-Inyo high- $\mathrm{SiO}_{2}$ rhyolites (fig. 27A), have negative slopes projecting along a fractionation line from K-feldspar and (or) biotite through the field of postcaldera dacites. This postcaldera rhyolite $\mathrm{Ba}-\mathrm{SiO}_{2}$ trend and a similar $\mathrm{Al}_{2} \mathrm{O}_{3}-\mathrm{SiO}_{2}$ trend projecting from plagioclase through dacite (fig. 28) suggest that the Mono-Inyo rhyolites and most other postcaldera Long Valley rhyolites evolved from coeval dacite by fractionation of feldspars, biotite, and, possibly, hornblende.

\section{Summary}

Postcaldera parental basalts of both the Caldera and Mono-Inyo suites appear to have been derived by nearly complete remelting of mafic lower crust or by mixing of N-MORB and lithospheric-mantle melts. The more evolved trachybasalts and trachyandesites formed by a two-stage process involving (1) assimilation of Mesozoic granitoids or mixing with coeval dacitic magma at midcrustal levels, followed by (2) major-element fractionation and selective diffusion of $\mathrm{Ba}$ and $\mathrm{K}$ during contact with sanidine-rich Moat Rhyolite or Mono-Inyo Craters rhyolitic magma at shallow crustal levels. The postcaldera dacites probably were largely derived by fractionation of trachybasalt-trachyandesite because they have Sr-isotopic compositions too low to have been derived by fusion of Mesozoic granitoids. $\mathrm{Low}-\mathrm{SiO}_{2}$ rhyolites associated with the postcaldera dacites, as well as most other intracaldera mid- to high- $\mathrm{SiO}_{2}$ rhyolites, also were likely derived by crystal fractionation of coeval dacitic magma.

\section{Tectonomagmatic Model}

Crough and Thompson (1977) speculated, on the basis of low Rayleigh-wave velocities beneath the crest of the Sierra Nevada, that Cenozoic thinning of the lithospheric mantle beneath the range is the cause of its uplift. Wernicke and others (1995) and Fliedner and others (1996) reported, on the basis of results of a multidisciplinary geophysical study of an east-west transect across the southern Sierra Nevada, that the crust beneath the southern Sierra Nevada is 34 to $42 \mathrm{~km}$ thick, only marginally thicker than beneath the western Basin and Range Province (30-34 km). They proposed that the Sierra Nevada gravity low, rather than being due to a thick low-density crustal root (Bateman and Eaton, 1967; Oliver, 1977), is 
the result of a hot, buoyant, asthenospheric-mantle upwelling displacing lithospheric mantle beneath the range crest. Ducea and Saleeby $(1996,1998)$ presented evidence, on the basis of mafic and ultramafic xenolith studies, that the asthenosphere lies close to the base of the crust immediately east of the Sierra Nevada crest and that the upper mantle and lower crust have been thinned, the upper mantle by convective erosion and (or) conversion to asthenosphere and the lower crust possibly by detachment of its eclogitic root. Thompson and Zoback (1979) and Zandt and others (1995) postulated a similar mantle upwelling at the east edge of the Basin and Range Province, beneath the Colorado Plateau Transition Zone. Thus, at the structurally and volcanically active western and eastern margins of the Basin and Range Province, proposed asthenospheric-mantle welts rise close to the base of the crust to depths shallower than beneath the central part of the province (fig. 29).

Although Ducea and Saleeby's (1996) conclusions are based on data mainly from the central Sierra Nevada and central Owens Valley, their model has yet to be confirmed by geophysical studies in the vicinity of Long Valley. Considerable uncertainty remains concerning the depth to the Moho beneath the central and northern Sierra Nevada (Savage and others, 1994). Clearly, a multidisciplinary trans-Sierran geophysical transect in the vicinity of Long Valley, similar to that across the southern Sierra Nevada (Wernicke and others, 1995), would be desirable-for example, across Pine Creek Pass in the Sierra Nevada to Westgard Pass in the White Mountains.
Geophysical uncertainties notwithstanding, petrologic, geochemical, and isotopic relations within the Long Valley Volcanic Field suggest a magmatic and structural model that is consistent with lithospheric-mantle thinning and formation of an asthenospheric-mantle welt beneath the volcanic field. These data, together with geochronologic and tectonic relations along the Owens Valley Rift and the East Sierran frontal fault zone, make an asthenospheric-mantle welt beneath the Pliocene Sierra Nevada crest an attractive model for the localization and evolution of volcanism at Long Valley and, possibly, at the Big Pine and Coso Volcanic Fields as well. At range-front offsets like those at the Long Valley, Big Pine, and Coso Volcanic Fields (fig. 1), where extensional deformation is probably intensified, localized domical upwellings rising from the asthenospheric mantle would provide the heat for localization of lithospheric-mantle melting, subcrustal magma ponding, crustal intrusion, and surface eruptions. Such a scenario also is consistent with the observed distinctive Long Valley precaldera and postcaldera magma compositions. A tectonomagmatic model for the evolution of the Long Valley Volcanic Field is outlined below and illustrated in figure 30.

Rapid extension along the Owens Valley Rift and the East Sierran frontal fault zone at about $4 \mathrm{Ma}$ initiated local thinning of the lithospheric mantle along the west edge of the alreadythinned lithosphere of the Basin and Range Province, giving rise to a north- to northwest-trending asthenospheric-mantle welt at the lithosphere-asthenosphere interface (fig. 30A).

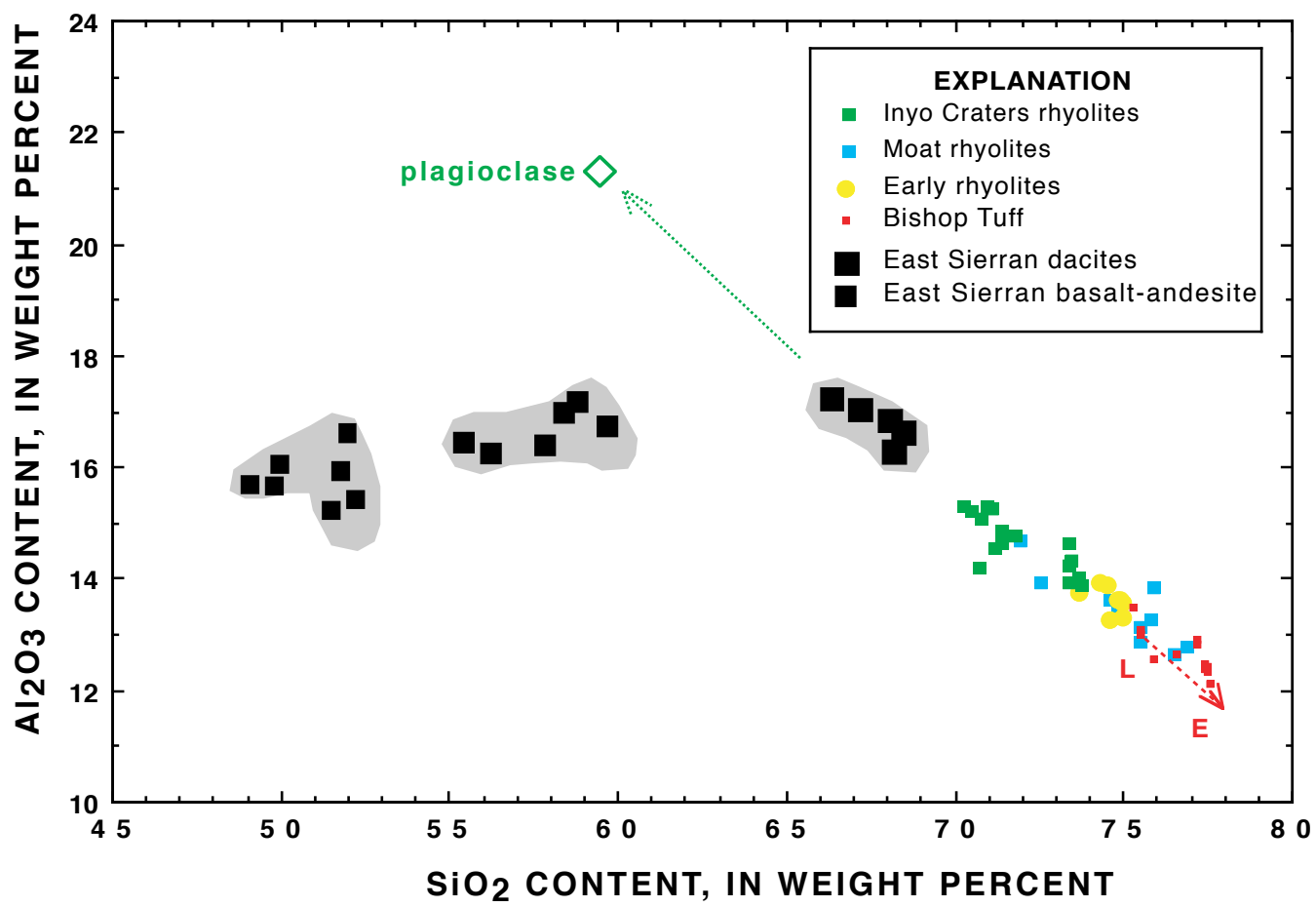

Figure 28. $\mathrm{Al}_{2} \mathrm{O}_{3}$ versus $\mathrm{SiO}_{2}$ contents for East Sierran lavas (gray areas) and postcaldera rhyolites, showing how postcaldera rhyolites (including the Bishop Tuff) project along a line suggesting derivation from dacite by plagioclase fractionation. $E$ and $L$, earliest- and latest-erupted compositions in the zoned Bishop Tuff. 
Decompression melting of this rising, possibly convecting asthenospheric-mantle welt above $80-\mathrm{km}$ depth and conductive heating, intrusion, and melting of the adjacent lithospheric mantle generated both asthenospheric and lithospheric melts that fed Central and East Sierran, as well as Basin and Range, basalts, although asthenospheric-mantle melt only rarely reached the surface. Most Central and East Sierran basalts were derived by small to moderate degrees of partial melting of garnet lherzolite at $60-$ to $100-\mathrm{km}$ depth, whereas to the east, Basin and Range basalts were derived by greater degrees of melting of spinel lherzolite above $60-\mathrm{km}$ depth. At about $3 \mathrm{Ma}$, slowing of regional extension inhibited passage of basalt to the surface and caused ponding of large volumes of lithospheric-mantle-derived melt at the base of and, possibly, in the lower crust. In the east half of the volcanic field (Basin and Range Province), partial fusion of the lithospheric mantle and, possibly, mafic lower crust, followed by fractionation of the generated melts, produced the earliest precaldera dacitic lavas. In the west half of the volcanic field (Sierra Nevada Province), mafic magmas rose to higher levels, melting lower-crustal to midcrustal rocks, generating the more highly evolved East Sierran dacites. At about $2.5 \mathrm{Ma}$, cessation of regional extension terminated the rise of all mafic and intermediate-composition magmas to the surface, resulting in increased accumulation of basalt in the lower crust and generation of large volumes of entrapped dacitic magma. Initially formed in relatively small, isolated chambers, this dacitic magma gradually coalesced into a megachamber, from which the Glass Mountain high- $\mathrm{SiO}_{2}$ rhyolite evolved. The heterogeneity of early, highly evolved Glass Mountain rhyolites (Metz and Mahood, 1991) between 2.1 and 1.1 Ma suggests formation in discrete cupolas or chambers above this dacitic megachamber; only after $1 \mathrm{Ma}$ did they coalesce and homogenize to form a single, continuous rhyolitic magma chamber, from which late Glass Mountain flows and the Bishop Tuff were erupted.

Shortly before the eruption of the Bishop Tuff and the formation of Long Valley Caldera (fig. 30B), renewed regional extension caused rapid injection of basalt into the base of the Long Valley (Bishop Tuff) magma chamber. This basalt is visualized as spreading laterally in multiple sheets across the floor of the chamber, in a manner similar to that described by Wiebe (1993a) for the floored Devonian plutons now exposed along the Maine coast-this "hotplate" effect possibly triggering eruption of the Bishop Tuff. After the eruption of the Bishop Tuff and the collapse of the caldera, basalt continued welling up into the base of the partially emptied magma chamber, forming chilled blobs, sills, and dikes in the partially molten residual rhyolite. Sufficiently hydrous to vesiculate, these mafic blobs and disrupted dike and sill fragments rose buoyantly to the chamber roof, aided by turbulent churning and thinning of the chamber caused by eruption of the Bishop Tuff; they were then transported to the surface as mafic enclaves in the Early and Moat Rhyolites. By this time, 760-500 ka, the asthenospheric-mantle welt had risen into the uppermost levels of the lithospheric mantle and impinged against mafic lower crust (fig. 30B), and so postcaldera basalt compositions reflect nearly complete melting of mafic lower crust or, possibly, mixing of lithospheric and asthenospheric mantle (N-MORB) melts.

The shift in asthenospheric-mantle-melt composition from OIB type at the onset of precaldera volcanism (4 Ma) to N-MORB type at the onset of postcaldera volcanism $(0.7$ Ma) may have resulted from convergence and gradual overriding of the subducted East Pacific Rise spreading center by the North American continental plate, wherein the precaldera OIB component was derived from the mantle wedge east of the subducting oceanic plate and the postcaldera $\mathrm{N}-\mathrm{MORB}$

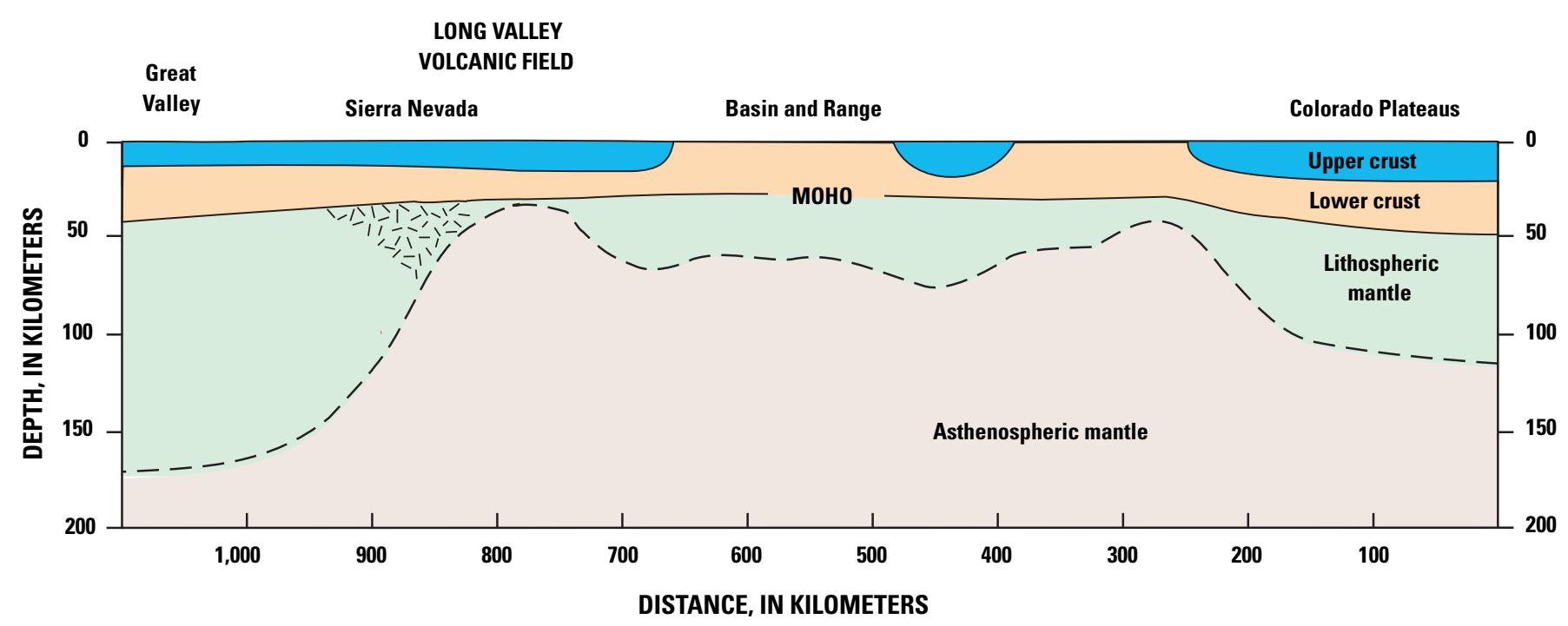

Figure 29. West-to-east cross section from the southern Sierra Nevada (lat $36.5^{\circ} \mathrm{N}$.) across the Basin and Range Province to the Colorado Plateaus Province, showing inferred crust-lithosphere-asthenosphere relations (after Wernicke and others, 1995; Zandt and others, 1995). Asthenospheric-mantle welts rising through lithospheric mantle to near lower-crustal interface are conspicuous features at both west and east edges of the Basin and Range Province. 

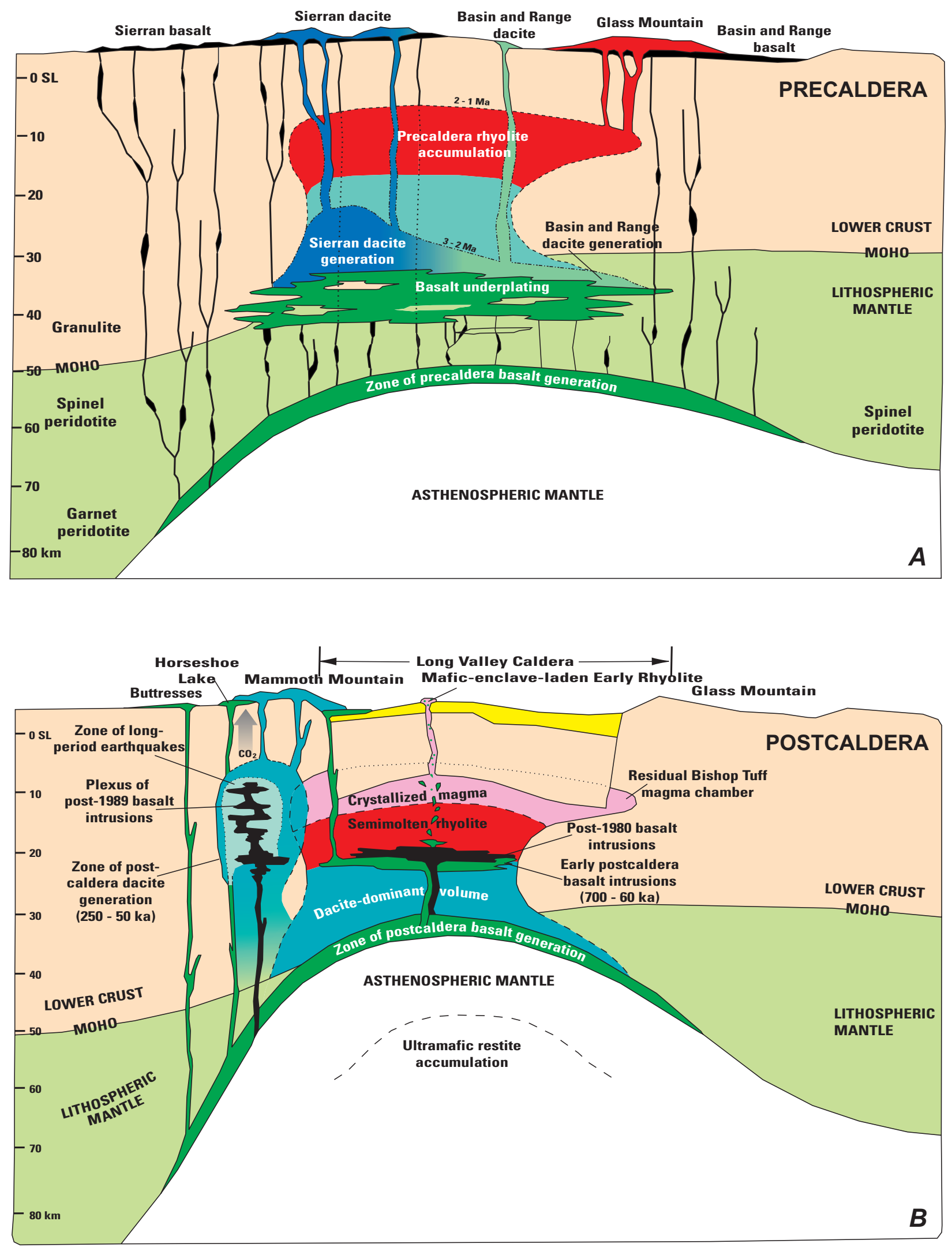

Figure 30. West-to-east cross sections of the Long Valley Volcanic Field, Calif., showing inferred subcrustal relations. $A$, During precaldera evolution (4-1 Ma). $B$, From 700 ka to present. Dashed lines defining regions of generation of various magmas do not define shapes of individual magma bodies, which are unknown and probably much more complex. 
component was derived from the slab gap west of the trailing edge of the sinking Farallon oceanic plate. The estimated convergence rate of 4 to $5.5 \mathrm{~cm} / \mathrm{yr}$ for the past $4.5 \mathrm{Ma}$ (Atwater and Molnar, 1973) implies a relative eastward migration of the slab gap of 120 to $165 \mathrm{~km}$, suggesting that it has moved from beneath the Great Valley to beneath the eastern Sierra Nevada in the past $3 \mathrm{~m} . \mathrm{y}$.

Between 4 and $1 \mathrm{Ma}$, the site of mafic-magma generation beneath the caldera rose $30 \mathrm{~km}$ as a result of extensional thinning and advective melting from the base of the lithospheric mantle (60-80-km depth) to the base of lower crust $(30-\mathrm{km}$ depth), requiring an average ascent rate of about $1 \mathrm{~cm} / \mathrm{yr}$, though certainly fluctuating in response to changing rates of regional extension. Gravitational unloading following partial emptying of the Bishop Tuff magma chamber and consequent isostatic rise of the subcauldron asthenosphere into the lower crust may have facilitated the sudden change in chemical signature of the postcaldera basalts and accelerated the influx of basalt into the residual Bishop Tuff magma chamber. By about $400 \mathrm{ka}$, ponded subcauldron basalt, migrating laterally beneath the "shadow zone" of the residual Bishop Tuff magma chamber, rose up in caldera ring fractures or along the incipient Mono-Inyo Craters fissures system and began to be erupted in the west moat. Fractionation and random mixing of basalt with coeval midcrustal dacitic magma (produced by basalt fractionation) and with rhyolitic magma at the margins of the Long Valley magma chamber generated the intracaldera trachyandesites, as well as the extracaldera flows at Mammoth Pass, Pumice Butte, and Devils Postpile. At about $250 \mathrm{ka}, \mathrm{low}-\mathrm{SiO}_{2}$ rhyolite and dacite began to be erupted at Mammoth Mountain and in the west moat. At the west edge of this zone of Caldera suite volcanism, the Buttresses and Horseshoe Lake basalts were generated by melting of lithospheric mantle at the steep asthenosphere interface (fig. 30B; see Ducea and Saleeby, 1996). At about $30 \mathrm{ka}$, basalt began migrating northward along the Mono-Inyo Craters fissure system and gave rise to the Mono-Inyo lavas, including the dacites and low- $\mathrm{SiO}_{2}$ rhyolites of Mono Lake, as well as the high- $\mathrm{SiO}_{2}$ rhyolites of Mono Craters. For the past 5,000 years, basaltic to dacitic eruptions have been confined to the north and south extremities of the Mono-Inyo Craters Volcanic Chain. This distribution suggests, in agreement with teleseismic evidence (Achauer and others, 1986; Dawson and others, 1990), that in the central part of the volcanic chain, where voluminous high- $\mathrm{SiO}_{2}$ rhyolite domes and flows have been erupted, a rhyolitic-magma chamber sufficiently large to produce a "shadow zone" may have inhibited upward passage of basaltic magma except at the extreme ends of the fissure system - at Black Point in the north and at Red Cones in the south.

The common occurrence of mafic enclaves in postcaldera rhyolitic members of the Long Valley Volcanic Field suggests that many, if not all, eruptions were triggered by injection of basalt into the root of the magmatic system (see Sparks and others, 1977). Such repeated influx of basalt, as noted by Lachenbruch and others (1976), is required to sustain its silicic-magma chamber in a semimolten state capable of pro- ducing eruptions over the past $1 \mathrm{~m} . \mathrm{y}$. Whether these eruptions were derived from a continuously maintained molten-magma chamber or by repeated remelting of previously congealed "granitic" parts of the chamber (Mahood, 1990) would depend on the frequency of basalt reinjection and the rate of regional extension, neither of which are presently well constrained.

The form of these rejuvenating basalt injections as multiple sheets at the base of the silicic-magma chamber is inferred from apparent subcauldron analogs of the Long Valley magma chamber observed in the Paleozoic and Mesozoic granitic plutons at Cordillera del Paine, Chile (Michael, 1991), on Mount Desert Island and Isle de Haute, Maine (Wiebe, 1993a, b, 1994; Chapman and Rhodes, 1992), and in Onion Valley, eastern Sierra Nevada (Sisson and others, 1996), where numerous thin sill-like sheets of basalt, commonly with associated mafic cumulate layers (Sisson and others, 1996; Wiebe, 1997), invaded the lower levels of these floored (then semimolten) plutons (for the mechanics of such intrusions, see Snyder and Tait, 1995, 1998). A detail further supporting this analogy is the marked $\mathrm{Ni}$ and $\mathrm{Cr}$ depletion in Long Valley intracaldera basalts, suggesting subcauldron ponding and formation of mafic cumulates at depth, like those evident in these ancient plutonic complexes.

This model of a rising asthenospheric-mantle welt may also apply to the Coso and Big Pine Volcanic Fields. At Coso, the difference in chemical signatures between Pliocene and Pleistocene basalt lavas suggests a shift from lithosphericmantle (IAB like) to asthenospheric-mantle (OIB like) sources approximately contemporaneously with Long Valley. At the smaller, shorter-lived Pleistocene Big Pine Volcanic Field, however, only lavas with modified lithospheric-mantle signatures are present, suggesting that an asthenospheric-mantle cupola, if present, has not yet risen to lower-crustal levels.

Portrayal of the Long Valley magma chamber as an asymmetric, floored, semilaccolithic body (fig. 30; see Bailey, 1984; Bailey and Hill, 1990) is partly based on the form of the above-mentioned floored plutonic analogs but is mainly inferred from the work of Lachenbruch and others (1976), whose heat-flow studies indicate that no thermal source persisted beneath the east half of the caldera after its collapse. They speculated that the east half of the magma chamber was nearly completely emptied during the eruption of the Bishop Tuff and that during its collapse the chamber roof came to rest on the floor. In accord with the fact that post-Bishop Tuff intracaldera eruptions have been limited to the west half of the caldera, they further inferred that the deep magmatic root existed and has persisted only in the west half. An oblate, floored configuration of the chamber also is not inconsistent with seismic and geophysical studies, including gravity (Carle, 1988), seismic refraction (Hill, 1976, Luetgert and Mooney, $1985)$, teleseismic $P$-wave tomography and $S$-wave attenuation (Steeples and Iyer, 1976; Achauer and others, 1986; Dawson and others, 1990; Ponko and Sanders, 1994; Steck and Prothero, 1994; Sanders and others, 1995), and deformation analysis (Langbein and others, 1995). Although estimates of the depth, volume, and liquid fraction of the residual magma 
chamber based on these studies vary considerably, the bestconstrained estimates indicate a chamber with a roof at 5- to 7-km depth and a floor at 11 - to $15-\mathrm{km}$ depth, a volume of 500 to $1,500 \mathrm{~km}^{3}$, and a liquid fraction ranging from 5 to 36 volume percent. The model here proposed also is generally consistent with the teleseismic- $P$-wave-tomography models of Dawson and others (1990) and Steck and Prothero (1994), who defined a low-density zone in the upper part of the Long Valley magmatic system (at 5-30-km depth) and a deeper, higher-density root zone (at 50-60-km depth). They inferred this high-density root zone to represent "depleted" mantle, presumably generated by prolonged distillation of the lithospheric mantle and gradual accumulation of mafic restite components in the lower part of the system over its 4-m.y. lifespan. Alternatively, this zone could represent the detached, sinking eclogitic Sierra Nevadan root postulated by Ducea and Saleeby $(1996,1998)$.

\section{Recent Reactivation of Basaltic Magmatism}

The foregoing model provides some insight into the tectonic processes driving the current (post-1980) seismic unrest at Long Valley. Since 1980, shallow earthquake swarms have been concentrated in three general areas: (1) the south moat of the caldera, (2) the High Sierra granitic terrain south of the caldera, and (3) beneath Mammoth Mountain. At present, little evidence exists for unrest beneath the northern part of the Mono-Inyo Craters Volcanic Chain, although briefly in 1990, faint swarms of long-period earthquakes were detected beneath Pumice Valley, east of the chain (A.M. Pitt, oral commun., 1990). In two of these seismically active areas (the south moat in 1980 and 1983 and Mammoth Mountain in 1989), magma of undetermined composition is inferred to have risen in dikes to within 2 to $3 \mathrm{~km}$ of the surface (Julian, 1983; Aki, 1984; Sanders, 1984; Savage and Cockerham, 1984; Hill and others, 1990; Langbein and others, 1995). Given the current seismicity and the postcaldera eruptive record, both areas are potential sites for future eruptions.

Mammoth Mountain was built between 250 and $50 \mathrm{ka}$ by extrusion of 30 or more dacite domes and flows but has been inactive since. This 50-k.y. quiescence after a 200-k.y. active period in which the average interval between eruptions was about 7 k.y. suggests that its source magma chamber has congealed and is unlikely to produce dacitic eruptions in the foreseeable future. However, the mountain has been the site of eruptions later than its dacite dome-building phase. At about 700 B.P., phreatic eruptions broke out from six or more vents on the north face of the mountain (Rinehart and Huber, 1965; Sorey and others, 1998) - probably forerunners of the 600B.P. basalt-triggered phreatic and rhyolitic eruptions at Inyo Craters (Varga and others, 1990; Mastin, 1991). Although the most recent basaltic eruptions in the vicinity of Mammoth Mountain occurred about $5 \mathrm{ka}$ at Red Cones, $3 \mathrm{~km}$ southwest of the mountain, active mantle- $\mathrm{CO}_{2}$-emitting soil and fumaroles along fissures and faults on its north and south flanks suggest that basaltic magma is again rising at depth.

Rhyolitic eruptions chemically related to the residual Long Valley magma chamber built the Mammoth Knolls rhyolite dome complex between 150 and $100 \mathrm{ka}$ in the southwest moat, but the latest southwest-moat eruption was basaltic, a 64-ka flow extending $3 \mathrm{~km}$ westward from the Mammoth Lakes townsite to Casa Diablo. Thus, both in the vicinity of Mammoth Mountain and in the southwest moat, the most recent eruptions have been basaltic. Coupled with the recent emission of mantle-derived $\mathrm{CO}_{2}$ and $\mathrm{He}$ and the occurrence of long-period earthquakes at $10-$ to $25-\mathrm{km}$ depth in the vicinity of Mammoth Mountain, basalt again appears to be invading the roots of the magmatic system, including beneath the floor of the Long Valley rhyolitic magma chamber, causing the current resurgent uplift. Although mantle-derived $\mathrm{CO}_{2}$ has not been detected in fumaroles or soils on or peripheral to the resurgent dome (Sorey and others, 1998), its absence may be due to entrapment of magmatic $\mathrm{CO}_{2}$ below or within the rhyolitic-magma chamber. In contrast, the absence of a partially molten residual magma chamber beneath Mammoth Mountain allows unimpeded flow of magma through a plexus of dikes and sills to depths as shallow as $10 \mathrm{~km}$ and the release of magmatic gases to a shallower vapor-gas reservoir, thence to near-surface faults and fissures, and finally to widespread dispersal in surface soils (Gerlach and others, 1998; Sorey and others, 1998).

\section{Future Volcanism and Hazards}

The volume of magma (presumably basaltic) modeled to account for post-1979 inflation of the resurgent dome (neglecting any contribution from thermal expansion of the subcauldron rocks and the hydrothermal system) is about $0.3 \mathrm{~km}^{3}$ (Langbein and others, 1995), nearly 3 times that of the most recent individual postcaldera rhyolitic or basaltic eruptions. Little is known about the volume of injected magma required to trigger an eruption, virtually nothing is known about the volume of resurgence that may have preceded earlier postcaldera eruptions at Long Valley, and little is known from similar intracaldera eruptions elsewhere in the world. Although an influx of $0.3 \mathrm{~km}^{3}$ of magma may seem insufficient to trigger an eruption of any significant size, any eruption, however small, could be highly disruptive locally, particularly should it occur in winter, when melting of heavy snow cover could generate swift-moving debris flows and mudflows (lahars). Given the long postcaldera record of sporadic eruptions, all of small volume, an eruption approaching the magnitude of the Bishop Tuff $\left(600 \mathrm{~km}^{3}\right)$ is extremely unlikely. However, if the ratio of eruptive volume to total magma-chamber volume for large rhyolitic eruptions is about 1:10, as estimated by Smith (1979), then the theoretical eruptive output of a Long Valley magma chamber with a residual volume of 30 to possibly 
$100 \mathrm{~km}^{3}$ (Dawson and others, 1990) could reach several cubic kilometers. Such an eruption, though only a fraction of that of the Bishop Tuff, could seriously impact the region, as well as much of the Western United States. Although the threshold volume of new magma required to trigger such an eruption is unknown, at the present estimated rate of basalt influx $(\leq 0.02$ $\mathrm{km}^{3} / \mathrm{yr}$ ), the required volume probably would take many decades, possibly centuries, to accumulate. All of the above estimates are fraught with large uncertainties, however, and there is no substitute for diligent, persistent monitoring during episodes of seismic and magmatic unrest.

Viewed in terms of episodicity, a rhyolitic eruption from the Long Valley magma chamber in the near future seems unlikely. Because the interval between postcaldera rhyolitic eruptions derived from the Long Valley magma chamber in the past $700 \mathrm{k} . \mathrm{y}$. is about $200 \mathrm{k} . \mathrm{y}$. and the latest eruption (Mammoth Knolls) was $100 \mathrm{ka}$, the next eruption might not be expected for about another 100 k.y.-a statistically tenuous estimate. Nonetheless, rhyolitic eruptions along the MonoInyo Craters Volcanic Chain have occurred at 250- to 700-year intervals over the past 5 k.y., the latest at Paoha Island between about A.D. 1700 and 1850 (Stine, 1987). Thus, the probability of an eruption from the Mono-Inyo Craters Volcanic Chain seems much higher and could be considered either overdue or unlikely for another 500 years. The relatively passive Paoha Island eruptions, which included uplift of lake-bottom sedimentary deposits by a rhyolite cryptodome and the formation of several small dacite cinder cones and a lava flow, probably posed little danger to humans; however, the 650-B.P. pyroclastic eruptions at Mono Craters and Inyo Craters probably did pose a serious threat to the Native American population at that time, although no reliable records or oral traditions of their observation or impact are known. None of these recent eruptions seriously impacted the sites of the present local population centers at Lee Vining, June Lake, or Mammoth Lakes, although 2 to $8 \mathrm{~cm}$ of ash and pumice fell on the outskirts of the present townsite of Mammoth Lakes (Miller, 1985).

In view of the current seismic unrest, the probability of a basaltic eruption from Long Valley Caldera seems much higher than of an explosive rhyolitic one; however, the recurrence intervals of recent basaltic eruptions in the Long Valley area is poorly known. Several basaltic eruptions occurred around the base of Mammoth Mountain and in Devils Postpile National Monument about 100 ka, near June Lake about 30 ka, at Black Point about $13 \mathrm{ka}$, and at Red Cones about $5 \mathrm{ka}$. The current (post-1980) seismic unrest in the vicinity of Mammoth Mountain may portend a similar small basaltic eruption-possibly west of the mountain near Devils Postpile or southeast of it in the Horseshoe Lake $\mathrm{CO}_{2}$-tree-kill area, both sites of former vents for relatively recent basaltic eruptions. However, with resurgent-dome inflation proceeding at an average rate of $2 \mathrm{~cm} / \mathrm{yr}$ but intermittently at short-term rates of as much as 20 cm/yr (D.P. Hill, oral commun., 1998), an intracaldera eruption, either basaltic or rhyolitic (possibly triggered by basalt influx), cannot be dismissed. Nevertheless, such seismic unrest and apparent precursory activity within large calderas does not invariably culminate in an eruption; the worldwide record at large calderas (Newhall and Dzurisin, 1988) indicates that in 60 episodes of seismic unrest recognized in historical time, only 10 have produced eruptions.

\section{References Cited}

Achauer, Ulrich, Greene, Lizbeth, Evans, J.R., and Iyer, H.M., 1986, Nature of the magma chamber underlying the Mono Craters area, eastern California, as determined from teleseismic travel time residuals: Journal of Geophysical Research, v. 91, no. B14, p. 13873-13891.

Aki, Keiiti, 1984, Evidence for magma intrusion during the Mammoth Lakes earthquakes of May 1980 and implications of the absence of volcanic (harmonic) tremor: Journal of Geophysical Research, v. 89, no. B9, p. 7689-7696.

Asmerom, Yemane, Jacobsen, S.B., and Wernicke, B.P., 1994, Variations in magma source regions during large-scale continental extension, Death Valley region, Western United States: Earth and Planetary Science Letters, v. 125, no. 1-4, p. 235-254.

Atwater, Tanya, and Molnar, Peter, 1973, Relative motion of the Pacific and North American plates deduced from seafloor spreading in the Atlantic, Indian, and South Pacific oceans, in Proceedings of conference on tectonic problems of the San Andreas Fault system: Stanford University Publications in Geological Sciences, v. 13, p. 136-148.

Bacon, C.R., 1986, Magmatic inclusions in silicic and intermediate volcanic rocks: Journal of Geophysical Research, v. 91, no. B6, p. 6091-6112.

Bacon, C.R., Bruggman, P.E., Christiansen, R.L., Clynne, M.A., Donnelly-Nolan, J.M., and Hildreth, Wes, 1997, Primitive magmas at five Cascade volcanic fields; melts from hot, heterogeneous sub-arc mantle: Canadian Mineralogist, v. 35, no. 2, p. 397-423.

Bacon, C.R., and Druit, T.H., 1988, Compositional evolution of the zoned calcalkaline magma chamber of Mount Mazama, Crater Lake, Oregon: Contributions to Mineralogy and Petrology, v. 98, no. 2, p. 224-256.

Bacon, C.R., and Metz, Jenny, 1984, Magmatic inclusions in rhyolites, contaminated basalts, and compositional zonation beneath the Coso Volcanic Field, California: Contributions to Mineralogy and Petrology, v. 85, no. 4, p. 346-365.

Baedecker, P.A., and McKown, D.M., 1987, Instrumental neutron activation analysis of geochemical samples, in Baedecker, P.M., ed., Methods for geochemical analysis: U.S. Geological Survey Bulletin 1770, p. H1-H14. 
Bailey, R.A., 1982, Other potential eruption centers in California; Long Valley-Mono Lake, Coso, and Clear Lake volcanic fields, in Martin, R.C., and Davis, J.F., eds., Status of volcanic prediction and emergency response capabilities in volcanic hazard zones of California: California Division of Mines and Geology Special Publication 63, p. 17-28.

Bailey, R.A., 1983, Mammoth Lakes earthquakes and ground uplift; precursors to possible volcanic activity?: Earthquake Information Bulletin, v. 15, no. 3, p. 88-101.

Bailey, R.A., 1984, Chemical evolution and current state of the Long Valley magma chamber, in Hill, D.P., Bailey, R.A., and Ryall, A.S., eds., Proceedings of Workshop XIX; active tectonic and magmatic processes beneath Long Valley caldera, eastern California: U.S. Geological Survey Open-File Report 84-939, p. 24-40.

Bailey, R.A., 1989, Geologic map of Long Valley caldera, Mono-Inyo Craters volcanic chain, and vicinity, eastern California: U.S. Geological Survey Miscellaneous Investigations Series Map I-1933, 11 p., scale 1:62,500, 2 sheets.

Bailey, R.A., Dalrymple, G.B., and Lanphere, M.A., 1976, Volcanism, structure, and geochronology of Long Valley caldera, Mono County, California: Journal of Geophysical Research, v. 81, no. 5, p. 725-744.

Bailey, R.A., and Hill, D.P., 1990, Magmatic unrest at Long Valley caldera, California, 1980-1990: Geoscience Canada, v. 17 , no. 3 , p. 175-179.

Barker, P.F., 1995, Tectonic framework of the East Scotia Sea, in Taylor, Brian, ed., Backarc basins; tectonics and magmatism: New York, Plenum, p. 281-314.

Bateman, P.C., and Eaton, J.P., 1967, Sierra Nevada Batholith: Science, v. 158, no. 3807, p. 1407-1417.

Beanland, Sarah, and Clark, M.C., 1994, The Owens Valley fault zone, eastern California, and surface faulting associated with the 1872 earthquake: U.S. Geological Survey Professional Paper 1982, 29 p.

Benson, L.V., Burdett, J.V., Kashgarian, Michaele, Lund, S.P., Phillips, F.M., and Rye, R.O., 1996, Climatic and hydrologic oscillations in the Owens Lake basin and adjacent Sierra Nevada, California: Science, v. 274, no. 5288, p. 746-751.

Benson, L.V., Currey, D.R., Dorn, R.I., Lajoie, K.R., Oviatt, S.W., Robinson, S.W., Smith, G.I., and Stine, S.W., 1990, Chronology of expansion and contraction of four Great Basin lake systems during the past 35,000 years: Paleogeography, Paleoclimatology, Paleoecology, v. 78, p. 241-286.

Bischoff, J.L., Fitzpatrick, J.A., and Rosenbauer, R.J., 1993a, The solubility and stabilization of ikaite $\left(\mathrm{CaCO}_{3} \cdot 6 \mathrm{H}_{2} \mathrm{O}\right)$ from $0^{\circ}$ to $25^{\circ} \mathrm{C}$; environmental and paleoclimatic implications for thinolite tufa: Journal of Geology, v. 101, no. 1, p. 21-33.
Bischoff, J.L., Menking, K.N., Fitts, J.P., and Fitzpatrick, J.A., 1997, Climatic oscillations 10,000-155,000 yr B.P. at Owens Lake, California, reflected in glacial rock flour abundance and lake salinity in core OL-92: Quaternary Research, v. 48, no. 3, p. 313-325.

Bischoff, J.L., Stine, Scott, Rosenbauer R.J., Fitzpatrick, J.A., and Stafford, T.W., Jr., 1993b, Ikaite precipitation by mixing of shoreline springs and lake water, Mono Lake, California, USA: Geochimica et Cosmochimica Acta, v. 57, no. 16, p. 3855-3865.

Bradshaw, T.K., Hawkesworth, C.J., and Gallagher, Kerry, 1993, Basaltic volcanism in the southern Basin and Range; no role for a mantle plume: Earth and Planetary Science Letters, v. 116, no. 1-4, p. 45-62.

Bradshaw, T.K., and Smith, E.I., 1994, Polygenetic Quaternary volcanism at Crater Flat, Nevada: Journal of Volcanology and Geothermal Research, v. 63, no. 3-4, p. 165-182.

Brophy, J.G., Dorais, M.J., Donnelly-Nolan, J.M., and Singer, B.S., 1996, Plagioclase zonation styles in hornblende gabbro inclusions from Little Glass Mountain, Medicine Lake Volcano, California; implications for fractionation mechanisms and the formation of composition gaps: Contributions to Mineralogy and Petrology, v. 126, no. 1-2, p. 121-136.

Bursik, M.I., and Gillespie, A.R., 1993, Late Pleistocene glaciation of Mono Basin, California: Quaternary Research, v. 39, no. 1, p. 24-35.

Carle, S.F., 1988, Three dimensional gravity modeling of the geologic structure of Long Valley Caldera: Journal of Geophysical Research, v. 93, no. 11, p. 13237-13250.

Carder, D.S., 1973, Trans-California seismic profile, Death Valley to Monterey Bay: Seismological Society of America Bulletin, v. 63, no. 2, p. 571-586.

Chapman, Marshall, and Rhodes, J.M., 1992, Composite layering in the Isle au Haute igneous complex, Maine; evidence for periodic invasion of mafic magma into an evolving magma reservoir: Journal of Volcanology and Geothermal Research, v. 51, no. 1-2, p. 41-60.

Chaudet, R.E., 1986, The petrology and geochemistry of precaldera magmas, Long Valley Caldera, eastern California: Blacksburg, Virginia Polytechnic Institute, M.Sc. thesis, 34 p.

Chouet, B.A., 1996, Long period volcano seismicity; its source and use in eruption forecasting: Nature, v. 380, no. 6572, p. 309-316.

Christensen, J.N., and DePaolo, D.J., 1993, Time scales of large volume silicic magma systems; Sr isotopic systematics of phenocrysts and glass from the Bishop Tuff, Long Valley, California: Contributions to Mineralogy and Petrology, v. 113, no. 1, p. 100-114. 
Christensen, M.N., 1966, Late Cenozoic crustal movements in the Sierra Nevada of California: Geological Society of America Bulletin, v. 77, no. 2, p. 163-182.

Council, T.C., and Bennett, P.C., 1993, Geochemistry of ikaite formation at Mono Lake, California; implications for the origin of tufa mounds: Geology, v. 21, no. 11, p. 971-974.

Cousens, B.L., 1996, Magmatic evolution of Quaternary mafic magmas at Long Valley Caldera and the Devils Postpile, California; effects of crustal contamination on the lithospheric mantle-derived magmas: Journal of Geophysical Research, v. 101, no. B12, p. 27673-27689.

Crough, S.T., and Thompson, G.A., 1977, Upper mantle origin of Sierra Nevada uplift: Geology, v. 5, no. 7, p. 396-399.

Curry, R.R., 1971, Glacial and Pleistocene history of the Mammoth Lake Sierra, a geologic guidebook: Missoula, University of Montana, Department of Geology Geological Series Publication, v. 2, no. 11, 47 p.

Davies, G.R., Halliday, A.N., Mahood, G.A., and Hall, C.M., 1994, Isotopic constraints on the production rates, crystallization histories and residence times of pre-caldera silicic magmas, Long Valley, California: Earth and Planetary Science Letters, v. 125, no. 1, p. 17-37.

Davies, G.R., and Halliday, A.N., 1998, Development of the Long Valley rhyolitic magma system; strontium and neodymium isotope evidence from glasses and individual phenocrysts: Geochimica et Cosmochimica Acta, v. 62, no. 21-22, p. 3561-3574.

Dawson, P.B., Evans, J.R., and Iyer, H.M., 1990, Teleseismic tomography of the compressional wave velocity structure beneath the Long Valley region, California: Journal of Geophysical Research, v. 95, no. B7, p. 11021-11050.

Ducea, M.N., and Saleeby, J.B., 1996, Buoyancy sources for a large, unrooted mountain range, the Sierra Nevada, California; evidence from xenolith thermobarometry: Journal of Geophysical Research, v. 101, no. B4, p. 8229-8244.

Ducea, M.N., and Saleeby, J.B., 1998, The age and origin of a thick mafic-ultramafic keel from beneath the Sierra-Nevada Batholith: Contributions to Mineralogy and Petrology, v. 133, no. 1-2, p. 169-185.

Eaton, G.P., 1982, The Basin and Range Province; origin and tectonic significance: Annual Review of Earth and Planetary Sciences, v. 10, p. 409-440.

Eichelberger, J.C., Vogel, T.A., Younker, L.W., Miller, C.D., Heiken, G.H., and Wohletz, K.H., 1988, Structure and stratigraphy beneath a young phreatic vent; South Inyo Crater, Long Valley Caldera, California: Journal of Geophysical Research, v. 93, no. B11, p. 13208-13220.

Ellam, R.M., 1992, Lithosphere thickness as a control on basalt geochemistry: Geology, v. 20, no. 2, p. 153-156.
Farmer, G.L., Glazner, A.F., Wilshire, H.G., Wooden, J.L., Pickthorn, W.J., and Katz, Marvin, 1995, Origin of late Cenozoic basalts at the Cima volcanic field, Mojave Desert, California: Journal of Geophysical Research, v. 100, no. B5, p. 8399-8415.

Farrar, C.D., Sorey, M.L., Evans, W.C., Howle, J.F., Kerr, B.D., Kennedy, B.M., King, C.Y., and Southon, J.R., 1995, Forest-killing diffuse $\mathrm{CO}_{2}$ emission at Mammoth Mountain, eastern California as a sign of magmatic unrest: Nature, v. 376 , no. 6542, p. 675-678.

Feuerbach, D.L., Smith, E.I., Walker, J.D., and Tangeman, J.A., 1993, The role of the mantle during crustal extension; constraints from geochemistry of volcanic rocks in the Lake Mead area, Nevada and Arizona: Geological Society of America Bulletin, v. 105, no. 12, p. 1561-1575.

Fitton, J.G., James, D.E., Kempton, P.D., Ormerod, D.D., and Leeman, W.P., 1988, The role of lithospheric mantle in the generation of late Cenozoic basic magmas in the Western United States, in Menzies, M.A., and Cox, K.G., eds., Oceanic and continental lithosphere; similarities and differences: Oxford, U.K., Clarendon Press, p. 331-349.

Fitton, J.G., James, D.E., and Leeman, W.P., 1991, Basaltic magmatism associated with Late Cenozoic extension in the Western United States; compositional variations in space and time: Journal of Geophysical Research, v. 96, no. B8, p. 13693-13711.

Fliedner, M.M., Ruppert, S.D., Malin, P.E., Park, S.K., Jiracek, G.R., Phinney, R.A., Saleeby, J.B., Wernicke, B.P., Clayton, R.W., Keller, G.R., Miller, K.C., Jones, C.H., Luetgert, J.H., Mooney, W.D., Oliver, H.L., Klemperer, S.L., and Thompson, G.A., 1996, Three-dimensional crustal structure of the southern Sierra Nevada from seismic fan profiles and gravity modeling: Geology, v. 24, no. 4, p. 367-370.

Frost, T.P., and Mahood, G.A., 1987, Field, chemical, and physical constraints on mafic-felsic magma interaction in the Lamarck Granodiorite, Sierra Nevada, California: Geological Society of America Bulletin, v. 99, no. 2, p. 272-291.

Gerlach, T.M., Doukas, M.P., McGee, K.A., and Kessler, Richard, 1998, Three-year decline of magmatic $\mathrm{CO}_{2}$ emissions from soils of a Mammoth Mountain tree kill; Horseshoe Lake, California, 1995-1997: Geophysical Research Letters, v. 25, no. 11, p. 1947-1950.

Gilbert, C.M., 1938, Welded tuff in eastern California; Geological Society of America Bulletin, v. 49, no. 12, pt. 1, p. 1829-1862.

Gilbert, C.M., 1941, Late Tertiary geology southeast of Mono Lake, California: Geological Society of America Bulletin, v. 52, no. 6, p. 781-815. 
Gilbert, C.M., Christensen, M.N., Al-Rawi, Yehya, and Lajoie, K.R., 1968, Structural and volcanic history of Mono Basin, California-Nevada, in Coats, R.R., ed., Studies in volcanology; a memoir in honor of Howel Williams: Geological Society of America Memoir 116, p. 275-329.

Glazner, A.F., and Farmer, G.L., 1992, Production of isotopic variability in continental basalts by cryptic crustal contamination: Science, v. 255, no. 5040, p. 72-74.

Glazner, A.F., Farmer, G.L., Hughes, W.T., Wooden, J.L., and Pickthorn, W.J., 1991, Contamination of basaltic magma by mafic crust at Amboy and Pisgah Craters, Mojave Desert, California: Journal of Geophysical Research, v. 96, no. B8, p. 13673-13691.

Grove, T.J., and Donnelly-Nolan, J.M., 1986, The evolution of young silicic lavas at Medicine Lake Volcano, California; implications for the origin of compositional gaps in calc-alkaline series lavas: Contributions to Mineralogy and Petrology, v. 92, no. 3, p. 281-302.

Halliday, A.N., 1990, Reply to comment of R.S.J. Sparks, H.E. Huppert, and C.J.N. Wilson on "Evidence for long residence times of rhyolitic magma in the Long Valley magmatic system; the isotope record in precaldera lavas of Glass Mountain": Earth and Planetary Science Letters, v. 99, no. 4, p. 390-394.

Halliday, A.N., Mahood, G.A., Holden, Peter, Metz, J.M., Dempster, T.J., and Davidson, J.P., 1989, Evidence for long residence times of rhyolitic magmas in the Long Valley magmatic system; the isotopic record in precaldera lavas of Glass Mountain: Earth and Planetary Science Letters, v. 94, no. 3-4, p. 274-290.

Hanchar, J.M., Miller, C.F., Wooden, J.L., Bennett, V.C., and Staude, J.-M.G., 1994, Evidence from xenoliths for a dynamic lower crust, eastern Mojave Desert, California: Journal of Petrology, v. 35, no. 5, p. 1377-1415.

Heumann, Arnd, and Davies, G.R., 1997, Isotopic and chemical evolution of the post-caldera rhyolitic system at Long Valley, California, Journal of Petrology: v. 38, no. 12, p. 1661-1678.

Hildreth, Wes, 1979, The Bishop Tuff; evidence for the origin of compositional zoning in silicic magma chambers, in Chapin, C.E., and Elston, W.E., eds., Ash-flow tuffs: Geological Society of America Special Paper 180, p. 43-72.

Hill, D.P., 1976, Structure of Long Valley Caldera, California, from a seismic refraction experiment: Journal of Geophysical Research, v. 81, no. 5, p. 745-753.

Hill, D.P., 1996, Earthquakes and carbon dioxide beneath Mammoth Mountain, California: Seismological Research Letters, v. 67, no. 1, p. 8-15.

Hill, D.P., Bailey, R.A., and Ryall, A.S., 1985a, Active tectonic and magmatic processes beneath Long Valley caldera, eastern California; an overview: Journal of Geophysical Research, v. 90, no. B13, p. 11111-11120.

Hill, D.P., Ellsworth, W.L., Johnston, M.J.S., Langbein, J.O., Oppenheimer, D.H., Pitt, A.M., Reasenberg, P.A., Sorey, M.L., and McNutt, S.R., 1990, The 1989 earthquake swarm beneath Mammoth Mountain, California; an initial look at the 4 May through 30 September activity: Seismological Society of America Bulletin, v. 80, no. 2, p. 325-339.

Hill, D.P, Wallace, R.E., and Cockerham, R.S., 1985b, Review of evidence on the potential for major earthquakes and volcanism in the Long Valley-Mono Craters-White Mountains regions of eastern California: Earthquake Prediction Research, v. 3, no. 3-4, p. 571-594.

Hilton, D.R., 1996, The helium and carbon isotope systematics of a continental geothermal system; results of monitoring studies at Long Valley Caldera (California, U.S.A.): Chemical Geology, v. 127, no. 4, p. 269-295.

Huber, N.K., 1981, Amount and timing of late Cenozoic uplift and tilt of the Central Sierra Nevada, California-evidence from the Upper San Joaquin River Basin: U.S. Geological Survey Professional Paper 1197, 28 p.

Huber, N.K., and Rinehart, C.D., 1967, Cenozoic volcanic rocks of the Devils Postpile quadrangle, eastern Sierra Nevada, California: U.S. Geological Survey Professional Paper 554-D, p. D1-D19.

Johnson, C.M., and O’Neil, J.R., 1984, Triple junction magmatism; a geochemical study of Neogene volcanic rocks in western California: Earth and Planetary Science Letters, v. 71 , no. 2, p. 241-262.

Julian, B.R., 1983, Evidence for dyke intrusion earthquake mechanisms near Long Valley Caldera, California: Nature, v. 303, no. 5915, p. 323-325.

Kelleher, P.C., and Cameron, K.L., 1990, The geochemistry of the Mono Craters-Mono Lake volcanic complex, eastern California: Journal of Geophysical Research, v. 95, no. B11, p. 17643-17659.

Kempton, P.D., Fitton, J.G., Hawkesworth, C.J., and Ormerod, D.S., 1991, Isotopic and trace-element constraints on the composition and evolution of the lithosphere beneath the southwestern United States: Journal of Geophysical Research, v. 96, no. B8, p. 13713-13735.

Kistler, R.W., 1993, Mesozoic intrabatholithic faulting, Sierra Nevada, California, in Dunn, G.C., and McDougall, K.A., eds., Mesozoic paleogeography of the Western United States; II: Los Angeles, Society of Economic Paleontologists and Mineralogists, Pacific Section Field Trip Guidebook, v. 71, p. 247-261.

Kistler, R.W., and Peterman, Z.E., 1973, Variations in Sr, Rb, $\mathrm{K}, \mathrm{Na}$, and initial ${ }^{87} \mathrm{Sr} /{ }^{86} \mathrm{Sr}$ in Mesozoic granitic rocks and 
intruded wall rocks in central California: Geological Society of America Bulletin, v. 84, no. 11, 3489-3512.

Kistler, R.W., and Peterman, Z.E., 1978, Reconstruction of crustal blocks of California on the basis of initial strontium isotopic compositions of Mesozoic granitic rocks: U.S. Geological Survey Professional Paper 1071, 17 p.

Koeppen, R.P., 1983, Petrochemical evolution of Mammoth Mountain, Long Valley Caldera, Eastern California [abs.]: Eos (American Geophysical Union Transactions), v. 64, no. 45, p. 889.

Lachenbruch, A.H., Sass, J.H., Munroe, R.J., and Moses, T.H., Jr., 1976, Geothermal setting and simple heat conduction models for the Long Valley Caldera: Journal of Geophysical Research, v. 81, no. 5, p. 769-784.

Lajoie, K.R., 1968, Late Quaternary stratigraphy and geologic history of Mono Basin, eastern California: Berkeley, University of California, Ph.D. thesis, 271 p.

Langbein, J.O., Dzurisin, Daniel, Marshall, Grant, Stein, R.S., and Rundle, J.B., 1995, Shallow and peripheral volcanic sources of inflation revealed by modeling two-color geodimeter and leveling data from Long Valley Caldera, California, 1988-1992: Journal of Geophysical Research, v. 100 , no. B7, p. 12487-12495.

Langbein, J.O., Hill, D.P., Parker, T.N., and Wilkinson, S.K., 1993, An episode of reinflation of the Long Valley Caldera; eastern California; 1889-1991: Journal of Geophysical Research, v. 98, no. B9, p. 15851-15870.

Lange, R.B., Carmichael, I.S.E., and Renne, P.R., 1993, Potassic volcanism near Mono Basin, California; evidence for high water and oxygen fugacities inherited from subduction: Geology, v. 21, no. 10, p. 949-952.

Larson, R.C., Menard, H.W., and Smith, S.M., 1968, Gulf of California; a result of ocean-floor spreading and transform faulting: Science, v. 161, no. 3843, p. 781-784.

Leat, P.T., Thompson, R.N., Morrison, M.A., Hendry, G.L., and Dickin, A.P., 1988, Compositionally-diverse MioceneRecent rift-related magmatism in NW Colorado; partial melting and mixing of mafic magmas from three different asthenospheric and lithospheric mantle sources, in Menzies, M.A., and Cox, K.G., eds., Oceanic and continental lithosphere; similarities and differences: Oxford, U.K., Clarendon Press, p. 351-377.

Le Bas, M.J., Le Maitre, R.W., Streckeisen, Albert, and Zanettin, B.A., 1986, Chemical classification of volcanic rocks based on the total alkali-silica diagram: Journal of Petrology, v. 27, no. 3, p. 745-750.

Leeman, W.P., 1982, Tectonic and magmatic significance of strontium isotopic variations in Cenozoic volcanic rocks from the western United States: Geological Society of America Bulletin, v. 93, no. 6, p. 487-503.
Leeman, W.P., and Harry, D.L., 1993, A binary source model for extension-related magmatism in the Great Basin, western North America: Science, v. 262, no. 5139, p. 1550-1554.

Le Maitre, R.W., ed., 1989, A classification of igneous rocks and glossary of terms: Oxford, U.K., Blackwell Scientific, $193 \mathrm{p}$.

Luetgert, J.H., and Mooney, W.D., 1985, Crustal refraction profile of the Long Valley Caldera, California, from the January 1983 Mammoth Lakes earthquake swarm: Seismological Society of America Bulletin, v. 75, no. 1, p. 211-221.

Lum, C.C.L., Leeman, W.P., Foland, K.A., Kargel, J.A., and Fitton, J.G., 1989, Isotopic variations in continental basaltic lavas as indicators of mantle heterogeneity; examples from the Western U.S. Cordillera: Journal of Geophysical Research, v. 94, no. B6, p. 7871-7884.

Mahood, G.A., 1990, Second reply to comment of R.S.J. Sparks, H.E. Huppert, and C.J.N. Wilson on "Evidence for long residence times of rhyolitic magma in the Long Valley magmatic system; the isotope record in the precaldera lavas of Glass Mountain": Earth and Planetary Science Letters, v. 99, no. 4, p. 395-399.

Mankinen, E.A., Grommé, C.S., Dalrymple, G.B., Lanphere, M.A., and Bailey, R.A., 1986, Paleomagnetism and K-Ar ages of volcanic rocks from Long Valley Caldera, California: Journal of Geophysical Research, v. 91, no. B1, p. 633-652.

Mastin, L.G., 1991, The roles of magma and ground water in the phreatic eruptions of Inyo Craters, Long Valley Caldera, California: Bulletin of Volcanology, v. 53, no. 8, p. 579-596.

Matthes, F.E., chairman, 1939, Report of Committee on Glaciers, April 1939: American Geophysical Union Transactions of 1939 , pt. 4, p. 518-523.

Matthes, F.E., 1960, Reconnaissance of the geomorphology and glacial geology of the San Joaquin Basin, Sierra Nevada, California: U.S. Geological Survey Professional Paper 329, 62 p.

Mavko, B.B., and Thompson, G.A., 1983, Crust and upper mantle structure of the Northern and Central Sierra Nevada: Journal of Geophysical Research, v. 88, no. B7, p. 58745892 .

Menzies, M.A., 1989, Cratonic, circumcratonic and oceanic mantle domains beneath western United States: Journal of Geophysical Research, v. 94, no. B6, p. 7899-7915.

Menzies, M. A., Leeman, W.P., and Hawkesworth, C.P., 1983, Isotope geochemistry of Cenozoic volcanic rocks reveals mantle heterogeneity below western USA: Nature, v. 303, no. 5914, p. 205-209. 
Metz, J.M., and Bailey, R.A., 1993, Geologic map of Glass Mountain, Mono County, California, U.S. Geological Survey Miscellaneous Investigations Series Map I-1995, scale $1: 24,000$

Metz, J.M., and Mahood, G.A., 1985, Precursors to the Bishop Tuff eruption; Glass Mountain, Long Valley caldera, California: Journal of Geophysical Research, v. 90, no. B11, p. 11121-11126.

Metz, J.M., and Mahood, G.A., 1991, Development of the Long Valley, California, magma chamber recorded in precaldera rhyolite lavas of Glass Mountain: Contributions to Mineralogy and Petrology, v. 106, no. 3, p. 379-397.

Michael, P.J., 1991, Intrusion of basaltic magmas into a crystallizing granitic magma chamber; the Cordillera del Paine Pluton in southern Chile: Contributions to Mineralogy and Petrology, v. 108, no. 4, p. 396-418.

Miller, C.D., 1985, Holocene eruptions of the Inyo Volcanic Chain, California; implications for possible eruptions in Long Valley caldera: Geology, v. 13, no. 1, p. 14-17.

Miller, C.D., Mullineaux, D.R., Crandell, D.R., and Bailey, R.A., 1982, Potential hazards from future volcanic eruptions in the Long Valley-Mono Lake area, east-central California and Nevada — a preliminary assessment: U.S. Geological Survey Circular 877, 10 p.

Moore, J.G., and Dodge, F.C.W., 1980, Late Cenozoic volcanic rocks of the southern Sierra Nevada, California; I, Geology and petrology: Geological Society of America Bulletin, v. 91, no. 9, p. 515-518.

Muffler, L.J.P., and Williams, D.L., 1976, Geothermal investigations of the U.S. Geological Survey in Long Valley, California, 1972-1973: Journal of Geophysical Research, v. 81 , no. 5 , p. 721-724.

Mukasa, S.B., and Wilshire, H.G., 1997, Isotopic and traceelement compositions of upper mantle and lower crustal xenoliths, Cima volcanic field, California; implications for evolution of the subcontinental lithospheric mantle: Journal of Geophysical Research, v. 102, no. B9, p. 20133-20148.

Newhall, C.G., and Dzurisin, Daniel, 1988, Historical unrest at large calderas of the world: U.S. Geological Survey Professional Paper 1855, 2 v.

Nielsen, D., Mahood, G.A., Halliday, A.N., and Essene, E.J., 1991, Petrogenesis of precaldera mafic and intermediate lavas, Long Valley, CA [abs.]: Geological Society of America Abstracts with Program, v. 23, no. 2, p. 83.

Novak, S.W., and Bacon, C.R., 1986, Pliocene volcanic rocks of the Coso Range, Inyo County, California: U.S. Geological Survey Professional Paper 1383, 44 p.

Nye, C.J., and Reid, M.R., 1986, Geochemistry and primary and least fractionated lavas from Okmok Volcano, central
Aleutians; implications for arc magmagenesis: Journal of Geophysical Research, v. 91, no. B10, p. 10271-10287.

Oliver, H.W., 1977, Gravity and magnetic investigations of the Sierra Nevada batholith, California: Geological Society of America Bulletin, v. 88, no. 3, p. 445-461.

Ormerod, D.S., 1988, Late- to post-subduction magmatic transitions in the western Great Basin, U.S.A.: U.K., Open University, Ph.D. thesis, 331 p.

Ormerod, D.S., Hawkesworth, C.J., Rogers, N.W., Leeman, W.P., and Menzies, M.A., 1988, Tectonic and magmatic transitions in the western Great Basin, USA: Nature, v. 333, no. 6171, p. 349-353.

Ormerod, D.S., Rogers, N.W., and Hawkesworth, C.J., 1991, Melting of the lithospheric mantle; inversion modelling of alkali-olivine basalts from the Big Pine volcanic field, California: Contributions to Mineralogy and Petrology, v. 108, no. 3 , p. 305-317.

Pakiser, L.C., 1970, Structure of Mono Basin, California: Journal of Geophysical Research, v. 75, no. 20, p. 4077-4080.

Peacock, M.A., 1931, Classification of igneous rock series: Journal of Geology, v. 39, no. 1, p. 54-67.

Pearce, J.A., 1982, Trace element characteristics of lavas from destructive plate margins, in Thorpe, R.S., ed., Andesites; orogenic andesites and related rocks: New York, John Wiley \& Sons, p. 525-548.

Phillips, F.M., Zreda, M.G., Smith, S.S., Elmore, David, Kubik, P.W., and Sharma, Pankaj, 1990, Cosmogenic chlorine-36 chronology for glacial deposits at Bloody Canyon, eastern Sierra Nevada: Science, v. 248, no. 4962, p. 1529-1532.

Phillips, F.M., Zreda, M.G., Benson, L.V., Plummer, M.A., Elmore, David, and Sharma, Pankaj, 1996, Chronology for fluctuations in Late Pleistocene Sierra Nevada glaciers and lakes: Science, v. 274, no. 5288, p. 749-751.

Pitt, A.M., and Hill, D.P., 1994, Long-period earthquakes in the Long Valley caldera region, eastern California: Geophysical Research Letters, v. 21, no. 16, p. 1679-1682.

Ponko, S.C. and Sanders, C.O., 1994, Inversion of $P$ and $S$ wave attenuation structure, Long Valley Caldera, California: Journal of Geophysical Research, v. 99, no. 2, p. 2619-2635.

Raleigh, C.B., Sieh, Kerry, Sykes, L.R., and Anderson, D.L., 1982, Forecasting southern California earthquakes: Science, v. 217 , no. 4565 , p. 1097-1104.

Reid, M.R., and Ramos, F.C., 1996, Chemical dynamics of enriched mantle in the Southwestern United States; thorium isotope evidence: Earth and Planetary Science Letters, v. 138, no. 1-4, p. 67-81. 
Rinehart, C.D., and Huber, N.K., 1965, The Inyo Crater Lakesa blast in the past: California Division of Mines and Geology Mineral Information Service, v. 18, no. 9, p. 169-172.

Rinehart, C.D., and Ross, D.R., 1964, Geology and mineral deposits of the Mount Morrison quadrangle, Sierra Nevada, California: U.S. Geological Survey Professional Paper 385, $106 \mathrm{p}$.

Rudnick, R.L., and Fountain, D.M., 1995, Nature and composition of the continental crust; a lower crustal perspective: Reviews of Geophysics v. 33, no. 3, p. 267-309.

Russell, I.C., 1886-87, Quaternary history of Mono Valley, California: U.S. Geological Survey Annual Report 8, pt. 1, p. 261-394.

Ryall, A.S., Jr., and Ryall, Floriana, 1981, Spatial-temporal relations in seismicity preceding the May 1980, Mammoth Lakes, California, earthquakes: Seismological Society of America Bulletin, v. 71, no. 3, p. 741-760.

Ryall, A.S., Jr., and Ryall, Floriana, 1983, Spasmodic tremor and possible magma injection in Long Valley caldera, eastern California: Science, v. 219, no. 4591, p. 1432-1433.

Sampson, D.E., and Cameron, K.L., 1987, The geochemistry of the Inyo volcanic chain; multiple magma systems in the Long Valley region, eastern California: Journal of Geophysical Research, v. 92, no. B10, p. 10403-10421.

Sanders, C.O., 1984, Location and configuration of magma bodies beneath Long Valley, California, determined from anomalous earthquake signals: Journal of Geophysical Research, v. 89, no. B10, p. 8287-8302.

Sanders, C.O., Ponko, S.C., Nixon, L.D., and Schwartz, E.A., 1995, Seismological evidence for magmatic and hydrothermal structure in Long Valley caldera from local earthquake attenuation and velocity tomography: Journal of Geophysical Research, v. 100, no. B5, p. 8311-8326.

Saunders, A.D., Norry, M.J., and Tarney, John, 1988, Origin of MORB and chemically-depleted mantle reservoirs; trace element constraints, in Menzies, M.A., and Cox, K.G., eds., Oceanic and continental lithosphere; similarities and differences: Oxford, U.K., Clarendon Press, p. 415-445.

Savage, J.C., and Clark, M.M., 1983, Magmatic resurgence in Long Valley caldera, California; possible cause of the 1980 Mammoth Lakes earthquakes: Science, v. 217, no. 4559, p. 531-533.

Savage, J.C., and Cockerham, R.S., 1984, Earthquake swarm in Long Valley, California, January 1983; evidence for dike intrusion: Journal of Geophysical Research, v. 89, no. B10, p. $8315-8324$.

Savage, J.C., Lisowski, Michael, Svarc, J.L., and Gross, W.K., 1995, Strain accumulation across the central Nevada seismic zone, 1973-1994: Journal of Geophysical Research, v. 100, no. B10, p. 20257-20269.

Savage, M.K., Li, Li, Eaton, J.P., Jones, C.H., and Brune, J.H., 1994, Earthquake refraction profiles of the root of the Sierra Nevada: Tectonics, v. 13, no. 4, p. 803-817.

Sharp, R.P., and Birman, J.H., 1963, Additions to classical sequence of Pleistocene glaciations, Sierra Nevada, California: Geological Society of America Bulletin, v. 74, no. 8, p. 1079-1086.

Shearman, D.J., and Smith, A.J., 1985, Ikaite, the parent mineral of jarrowite-type pseudomorphs: Geologists' Association of London Proceedings, v. 96, no. 4, p. 305-314.

Sherburne, R.W., ed., 1980, Mammoth Lakes, California, earthquakes of May 1980: California Division of Mines and Geology Special Report 150, 141 p.

Sheridan, M.F., 1965, The mineralogy and petrology of the Bishop Tuff (Pleistocene of California): Stanford, Calif., Stanford University, Ph.D. thesis, 193 p.

Sieh, Kerry, and Bursik, M.I., 1986, Most recent eruption of the Mono Craters, eastern Central California: Journal of Geophysical Research, v. 91, no. B12, p. 12539-12571.

Sisson, T.W., Grove, T.L., and Coleman, D.S., 1996, Hornblende gabbro sill complex at Onion Valley, California, and a mixing origin for the Sierra Nevada Batholith: Contributions to Mineralogy and Petrology, v. 126, no. 1-2, p. 81-108.

Smith, Genny, 1993, Mammoth Lakes Sierra; handbook for road and trailside: Mammoth Lakes, Calif., Genny Smith Books, 220 p.

Smith, G.I, Bischoff, J.L., and Bradbury, J.P., 1997, Synthesis of the paleoclimate record from Owens Lake core OL-92, in Smith, G.I., and Bischoff, J.L., eds., An 800,000-year paleoclimatic record from corehole OL-92, Owens Lake, southeast California: Geological Society of America Special Paper 317, p. 143-160.

Smith, R.L., 1979, Ash-flow magmatism, in Chapin, C.E., and Elston W.E., eds., Ash-flow tuffs: Geological Society of America Special Paper 180, p. 5-27.

Smith, R.L. and Bailey, R.A., 1968, Resurgent cauldrons, in Coats, R.R., ed., Studies in volcanology; a memoir in honor of Howel Williams: Geological Society of America Memoir 116, p. 613-662.

Snyder, Don, and Tait, Stephen, 1995, Replenishment of magma chambers; comparison of fluid-mechanic experiments with field relations: Contributions to Mineralogy and Petrology, v. 122, no. 3, p. 230-240.

Snyder, Don, and Tait, Stephen, 1998, The imprint of basalt on the geochemistry of silicic magmas: Earth and Planetary Science Letters, v. 160, no. 3-4, p. 433-445. 
Sorey, M.L., Evans, W.C., Kennedy, B.M., Farrar, C.D., Hainsworth, L.J., and Hausback, B.P., 1998, Carbon dioxide and helium emissions from a reservoir of magmatic gas beneath Mammoth Mountain, California: Journal of Geophysical Research, v. 103, no. B7, p. 15303-15323.

Sorey, M.L., Kennedy, B.M., Evans, W.C., Farrar, C.D., and Suemnicht, G.A., 1993, Helium isotope and gas discharge variations associated with crustal unrest in Long Valley caldera, California: Journal of Geophysical Research, v. 98, no. B9, p. 15871-15880.

Sparks, R.S.J., Huppert, H.E., and Wilson, C.J.N., 1990, Comment on "Evidence for long residence times of rhyolitic magma in the Long Valley magmatic system; the isotopic record in precaldera lavas of Glass Mountain" by A.N. Halliday, G.A. Mahood, P. Holden, J. M. Metz, T.J. Dempster, and J.P. Davidson: Earth and Planetary Science Letters, v. 99, no. 4, p. 387-389.

Sparks, R.S.J., and Marshall, L.A., 1986, Thermal and mechanical constraints on mixing between mafic and silicic magmas: Journal of Volcanology and Geothermal Research, v. 29 , no. $1-4$, p. $99-124$.

Sparks, R.S.J., Sigurdsson, Haraldur, and Wilson, Lionel, 1977, Magma mixing; a mechanism for triggering acid explosive eruptions: Nature, v. 267, no. 5609, p. 315-318.

Steck, L.K., and Prothero, W.A., Jr., 1994, Crustal structure beneath Long Valley caldera from modeling of teleseismic $P$ wave polarizations and $P s$ converted waves: Journal of Geophysical Research, v. 99, no. B4, p. 6881-6898.

Steeples, D.W., and Iyer, H.M., 1976, Low-velocity zone under Long Valley as determined from teleseismic events: Journal of Geophysical Research, v. 81, no. 5, p. 849-860.

Stine, Scott, 1987, Mono Lake; the past 4000 years: Berkeley, University of California, Ph.D. thesis, 615 p.

Suemnicht, G.A., and Varga, R.J., 1988, Basement structure and implications for hydrothermal circulation patterns in the western moat of Long Valley Caldera, California: Journal of Geophysical Research, v. 93, no. B11, p. 13191-13207.

Sun, S.S., and McDonough, W.F., 1989, Chemical and isotopic systematics of oceanic basalts; implications for mantle composition and processes, in Saunders, A.D., and Norry, M.J., eds., Magmatism and the ocean basins: Geological Society of London Special Publication 42, p. 313-345.

Taggart, J.E., Jr., Lindsay, J.R., Scott, B.A., Vivit, D.V., Bartel, A.J., and Stewart, K.C., 1987, Analysis of geologic materials by wavelength-dispersive $\mathrm{X}$-ray fluorescence spectrometry: U.S. Geological Survey Bulletin 1770, p. E1-E19.

Taylor, S.R., and McLennan, S.M., 1985, The continental crust; its composition and evolution: Oxford, U.K., Blackwell Scientific, 312 p.
Thompson, G.A., and Zoback, M.L., 1979, Regional geophysics of the Colorado Plateau: Tectonophysics, v. 61, no. 1-3, p. 149-181.

Thompson, R.N., Morrison, M.A., Dicken, A.P., and Hendry, G.L., 1983, Continental flood basalts... arachnids rule OK?, in Hawkesworth, C.J., and Norry, M.J., eds., Continental basalts and mantle xenoliths: Nantwich, U.K., Shiva Publishing, p. 158-185.

Thompson, R.N., Morrison, M.A., Hendry, G.L., and Parry, S.J., 1984, An assessment of the relative roles of crust and mantle in magma genesis; an elemental approach: Royal Society of London Philosophical Transactions, ser. A, v. 310 , no. 1514 , p. 549-590.

Turner, S.P., and Hawkesworth, C.J., 1995, The nature of the sub-continental mantle; constraints from the major-element composition of continental flood basalts: Chemical Geology, v. 120, no. 3-4, p. 295-314.

Van Kooten, G.K., 1980, Mineralogy, petrology, and geochemistry of an ultrapotassic basaltic suite, central Sierra Nevada, USA: Journal of Petrology, v. 21, no. 4, p. 651-684.

Van Kooten, G.K., 1981, Pb and Sr systematics of ultrapotassic and basaltic rocks from the central Sierra Nevada, California: Contributions to Mineralogy and Petrology, v. 76, no. 4, p. 378-385.

Van Kooten, G.K., Leeman, W.P., and Menzies, M.A., 1985, Lithospheric peridotites and pyroxenites in alkaline basaltic rock from the Sierra Nevada, California, USA [abs.]: Eos (American Geophysical Union Transactions), v. 66, no. 18, p. 414.

Varga, R.J., Bailey, R.A., and Suemnicht, G.A., 1990, Evidence for 600 year-old basalt and magma mixing at Inyo Craters volcanic chain, Long Valley Caldera, California: Journal of Geophysical Research v. 95, no. B13, p. 2144121450 .

Vogel, T.A., Woodburne, T.B., Eichelberger, J.C., and Layer, P.W., 1994, Chemical evolution and periodic eruption of mafic lava flows in the west moat of Long Valley caldera, California: Journal of Geophysical Research, v. 99, no. B10, p. $19829-19842$.

Ward, P.L., 1991, On plate tectonics and the geological evolution of southwestern North America: Journal of Geophysical Research, v. 96, no. B7, p. 12479-12496.

Watson, E.B., 1982, Basalt contamination by continental crust; some experiments and models: Contributions to Mineralogy and Petrology, v. 80, no. 1, p. 73-87.

Welhan, J.A., Poreda, R.J., Rison, William, and Craig, Harmon, 1988, Helium isotopes in geothermal and volcanic gases of the western United States; 1 . Regional variability and magmatic origin: Journal of Volcanology and Geothermal Research, v. 34, no. 3-4, p. 185-199. 
Wenrich, K.J., Billingsley, G.H., and Blackjoy, B.A., 1995, Spatial migration and compositional changes of Miocene-Quaternary magmatism in the Western Grand Canyon: Journal of Geophysical Research, v. 100, no. B7, p. 10417-10440.

Wernicke, B.P., Clayton, R.W., Ducea, M.N., Jones, C.H., Park, S.K., Ruppert, S.D., Saleeby, J.B., Snow, J.K., Squires, L.J., Fliedner, M.M., Jiracek, G.R., Keller, G.R., Klemperer, S.L., Leutgert, J.H., Malin, P.E., Miller, K.C., Mooney, W.D., Oliver, H.W., and Phinney, R.A., 1995, Origin of high mountains in the continents; the southern Sierra Nevada: Science, v. 271, no. 5246, p. 190-193.

Wiebe, R.A., 1993a, Basaltic injections into floored silicic magma chambers: Eos (American Geophysical Union Transaction), v. 74, no. 1, p. 1-3.

Wiebe, R.A., 1993b, The Pleasant Bay layered gabbro-diorite, coastal Maine; ponding and crystallization of basaltic injections into a silicic magma chamber: Journal of Petrology, v. 34 , no. 3, p. 461-489.

Wiebe, R.A., 1994, Silicic magma chambers as traps for basaltic magmas; Cadillac Mountain intrusive complex, Mount Desert Island, Maine: Journal of Geology, v. 102, no. 4, p. 423-437.

Wiebe, R.A., 1997, Fe-rich tholeiitic liquids and their cumulate products in the Pleasant Bay layered intrusion, coastal
Maine: Contributions to Mineralogy and Petrology, v. 129, no. 4, p. 255-267.

Wilson, C.J.N., and Hildreth, Wes, 1997, The Bishop Tuff; new insights from eruptive stratigraphy: Journal of Geology, v. 105 , no. 4 , p. 407-439.

Wilson, C.J.N., and Hildreth, Wes, 1998, Hybrid fall deposits in the Bishop Tuff, California; a novel pyroclastic depositional mechanism: Geology, v. 26, no. 1, p. 7-10.

Yogodzinski, G.M., Naumann, T.R., Smith E.I., Bradshaw, T.K., and Walker, J.D., 1996, Evolution of a mafic volcanic field in the central Great Basin, south central Nevada: Journal of Geophysical Research, v. 101, no. B8, p. 1742517445 .

Zandt, George, Myers, S.C., and Wallace, T.C., 1995, Crust and mantle structure across the Basin and Range-Colorado Plateau boundary at $37^{\circ} \mathrm{N}$ latitude and implications for Cenozoic extensional mechanism: Journal of Geophysical Research, v. 100, no. B6, p. 10529-10548.

Zielinski, R.A., 1975, Trace element evaluation of a suite of rocks from Reunion Island, Indian Ocean: Geochimica et Cosmochimica Acta, v. 39, no. 5, p. 713-734.

Zielinski, R.A., and Lipman, P.W., 1976, Trace-element variations at Summer Coon volcano, San Juan Mountains, Colorado, and the origin of continental-interior andesite: Geological Society of America Bulletin, v. 87, no. 10, p. 1477-1485. 
